DOE/RL-91-28

Revision 4

UC-630

\title{
Hanford Facility Dangerous Waste Permit Application, General Information Portion
}

Date Published

May 1998

United States Department of Energy P.O. Box 550 Richland, Washington 99352 
TRADEMARK DISCLAMER

Reference herein to eny specific commercial product, process,

or service by trade neme, trademark, manufacturer, or otherwise, does not necesserily constitute or imply its endersement, recommendation, or favoring by the United States Government or any agency thereof or its contractors or subcontrectors.

This report hes been reproduced from the best available copy. Available in paper copy and microfiche.

Available to the U.S. Department of Energy and its contractors from

Office of Scientific and Technical Information

P.O. Box 62

Oek Ridge, TN 37831

(615) 576-8401

Available to the public from the U.S. Department of Commerce National Technical Information Service

5285 Port Roval Road

Springfield, VA 22161

(703) 487-4650

Printed in the United Stetes of Americe

DISCLM-5.CHP (8-91) 


\section{INFORMATION CLEARANCE FORM}

\begin{tabular}{l}
\multicolumn{2}{c}{ A. Information Category } \\
$\square$ Abstract \\
$\square$ Summary \\
$\square$ Visual Aid \\
$\square$ Full Paper \\
$\square$ Internal Article \\
O Other Permit Application
\end{tabular}

\begin{tabular}{l} 
B. Document Number DOE/RL-91-28, Rev. 4 \\
\hline C. Title \\
Hanford Facility Dangerous Waste Permit Application, General \\
Information Portion
\end{tabular}

D. Internet Address

E. Required Information

1. Is docum $($ nt potentially Classified? $[\mathrm{X}$ No $\square$ Yes (MANDATORY)

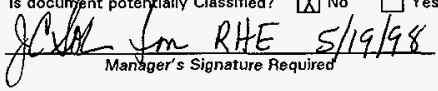

If Yes

$\square$ No $\square$ Yes Classified

ADC Signature Required

2. Internal Review Required?

If Yes, Document Signatures Below

D No $\square$ Yes

Counsel

(Cefento obleceles)

Program

3. References in the Information are Applied Yechnology

Export Controlled Information

$[\mathrm{X}$ No $\square$ Yes

$\square$ No $\square$ Yes
4. Does Information Contain the Following: (MANDATORY)

a. New or Novel (Patentable) Subject Matter? $\quad[X$ No $\quad \square$ Yes

If "Yes", Disclosure No.:

b. Information Received in Confidence, Such as Proprietary and/or Inventions?

$[X]$ No $\square$ Yes If "Yes", Affix Appropriate Legends/Notices.

c. Copyrights? $[\mathbb{X}]_{\text {No }} \square$ Yes If "Yes", Attach Permission.

d. Trademarks? $\square]$ No $\square$ Yes If "Yes", Identify in Document.

5. Is Information requiring submission to OSTI? $\square$ No $[X]$ Yes

if Yes $U C-630,2000$ and $B \& R-N A E W 3 / 3000$

6. Rolease Level? $[\mathrm{X}]$ Public $\square$ Limited

7. Charge code $\mathrm{RlAl7}$ cluepley $\# 18$

F. Complete for a Joumal Article

1. Title of Journal

G. Complete for a Presentation

1. Title for Conference or Meeting

2. Group Sponsoring

3. Date of Conference

4. City/State

5. Will information be Published in Proceedings? $\square$ No $\square$ Yes

6. Will Material be Handed Out? $\square$ No $\square$ Yes

J. C. Sonnichsen, Jr. Author/Requestor

I. Reviewers Yes Print Signature

Public VN (If $N$, complete J)

General Counsel

Office of External Affairs

DOE-RL

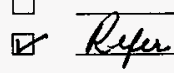

t

\section{cotached betten}

$Y / N$

Other

Other
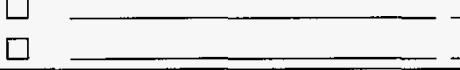

J. If Information Ineludes Sensitive Information and is not to be released to the Public indicate category below.

$\begin{array}{ll}\square \text { Applied Technology } & \square \text { Protected CRADA } \\ \square \text { Personal/Private } & \square \text { Export Controlled } \\ \square \text { Proprietary } & \square \text { Procurement-Sensitive } \\ \square \text { Business-Sensitive } & \square \text { Patentable } \\ \square \text { Predecisional } & \square \text { Other (Specify) } \\ \square \text { uCNI } & \end{array}$

K. If Additional Comments, Please Attach Separate Sheet 


\section{RELEASE AUTHORIZATION}

Document Number: $\quad$ DOE/RL-91-28, Rev. 4

$\begin{array}{ll} & \text { Hanford Facility Dangerous } \\ \text { Document Title: } & \text { General Information Portion }\end{array}$

This document, reviewed in accordance with DOE Order 1430.1D, "Scientific and Technical Information Management," and DOE G 1430.1D-1, "Guide to the Management of Scientific and Technical Information," does not contain classified or sensitive unclassified information and is:

APPROVED FOR PUBLIC RELEASE

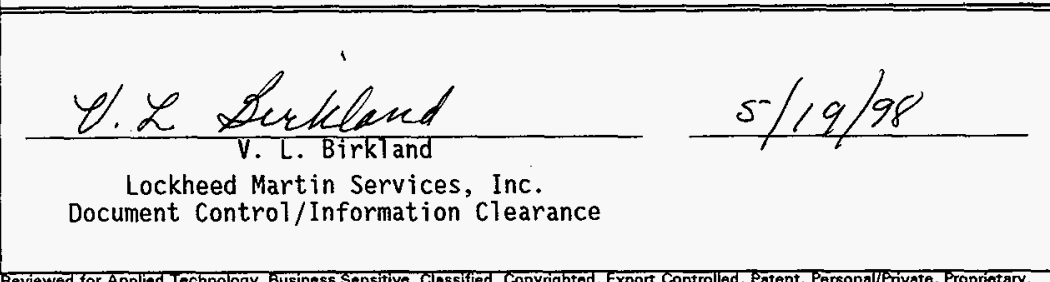

Reviewed for Applied Technology, Business Sensitive, Classified, Copyrighted, Export Controlled, Patent, Personallptivate, Proprietary. Protected CRADA, Trademark, Unclessified Controlled Nuclear Information.

LEGAL DISCLAIMER. This report was prepared as an account of work sponsored by ant agency of the United States Govemment. Neither the United States Govemment nor any agency thereof, not any of their employees, nor any of their contractors, subcontractors or their employees, makes any wartanty, express or implied, or assumes any legal liability or responsibility for the accuracy.

completeness, or any third party's use or the results of such use of eny information, apparatus, product, or process disclosed, or represents that ths use would not infringe privately owned rights. Reference herein to any specific commercial product, process, or service by trede namo, trademark, menufecturer, or otherwise, does not necessarily constitute or imply its endorsement,

recommendation, or favoring by the United States Govemment or any agency thereof or its contractors or subcontractors. The views and opinions of authors expressed herein do not necesserily state or reflect those of the United States Govemment or any agency thereof. This report has been reproduced from the best available copy. Printed in the United States of America. Available to the U.S. Department of Energy and its contractors from the U.S. Department of Energy Office of Scientific and Technical Information, P.O. Box 62, Oak Ridge. TN 37831: Telephone: 423/576-8401.

Available to the public from the U.S. Department of Commerce National Technical Information Service, 5285 Port Royal Road, Springfield, VA 22161; Talephone: $703 / 487-4650$. 


\section{HANFORD FACILITY \\ DANGEROUS WASTE PERMIT APPLICATION, GENERAL INFORMATION PORTION}

\section{FOREWORD}

The Hanford Facility, located in southeastern Washington State, is owned by the U:S: Government and operated by the U.S. Department of Energy, Richland Operations Office. Dangerous waste and mixed waste (containing both dangerous and radioactive components) are generated and managed on the Hanford Facility. Waste components are regulated in accordance with the Resource Conservation and Recovery Act of 1976, the Hazardous and Solid Waste Amendments of 1984, and/or the State of Washington Hazardous Waste Management Act of 1976 (as administered through the Washington State Department of Ecology Dangerous Waste Regulations, Washington Administrative Code 173-303); or the Atomic Energy Act of 1954.

The permitting framework for the Hanford Facility was established by the original 1989 Hanford Federal Facility Agreement and Consent Order (Ecology et al. 1996). The original document addressed the Hanford Facility as a single Resource Conservation and Recovery Act facility (U.S. Environmental Protection Agency/State Identification Number WA7890008967) consisting of over 60 treatment, storage, and/or disposal units. Approximately 25 percent of these units are, or are anticipated to be, 'operating'; approximately 50 percent are 'undergoing closure'; and approximately 25 percent are, or are anticipated to be, 'dispositioned through other options' under the Hanford Federal Facility Agreement and Consent Order.

The original Hanford Federal Facility Agreement and Consent Order also established a stepwise permitting process that provided for the issuance of an initial Resource Conservation and Recovery Act permit for less than the entire Hanford Facility. Any treatment, storage, and/or disposal units not included in the initial permit were to be incorporated through a permit modification. Treatment, storage, and/or disposal units not yet incorporated into the Resource Conservation and Recovery Act permit were to continue to operate under interim status. Subsequent amendments of the Hanford Federal Facility Agreement and Consent Order have retained the Resource Conservation and Recovery Act permitting framework established by the original 1989 document.

The initial Hanford Facility Resource Conservation and Recovery Act Permit became effective in September 1994, and is comprised of two portions, a Dangerous Waste Portion, issued by Ecology, and a Hazardous and Solid Waste Amendments Portion, issued by the U.S. Environmental Protection Agency, Region 10. The Dangerous Waste Portion is issued to four Permittees: the U.S. Department of Energy, Richland Operations Office, as the owner/operator, and to three of its contractors, as co-operators. The Hazardous and Solid Waste Amendments Portion is issued to the U.S. Department of Energy, Richland Operations Office, as the owner/operator.

For purposes of the Hanford Facility Dangerous Waste Permit Application, the U.S. Department of Energy's contractors are identified as 'co-operators' and sign in that capacity (refer to Condition I.A.2. of the Dangerous Waste Portion of the Hanford Facility Resource Conservation and Recovery Act Permit). Any identification of these contractors as an 'operator' elsewhere in the application is not meant to conflict with the contractors' designation as co-operators but rather is based on the contractors' contractual status with the U.S. Department of Energy, Richland Operations Office. 
The Hanford Facility Dangerous Waste Permit Application is considered to be a single application organized into a General Information Portion (this document, DOE/RL-91-28) and a Unit-Specific Portion. The scope of the Unit-Specific Portion is limited to individual 'operating' treatment, storage, and/or disposal units for which Part B permit application documentation has been, or is anticipated to be, submitted.

Documentation for treatment, storage, and/or disposal units 'undergoing closure', or for units that are, or are anticipated to be, 'dispositioned through other options', will continue to be submitted by the Permittees in accordance with the provisions of the Hanford Federal Facility Agreement and Consent Order. However, the scope of the General Information Portion includes information that could be used to discuss 'operating' units, units 'undergoing closure', or units being 'dispositioned through other options'.

The permit modification process is used to incorporate treatment, storage, and/or disposal units as permitting documentation for these units is finalized. The units to be included in annual modifications are specified in a schedule contained in the Dangerous Waste Portion of the Hanford Facility Resource Conservation and Recovery Act Permit. Treatment, storage, and/or disposal units will remain in interim status until incorporated into the Permit or dispositioned through other options.

Both the General Information and Unit-Specific portions of the Hanford Facility Dangerous Waste Permit Application address the contents of the Part $\mathrm{B}$ permit application guidance documentation prepared by the Washington State Department of Ecology (Ecology 1987 and 1996) and the U.S. Environmental Protection Agency ( 40 Code of Federal Regulations 270), with additional information needs defined by revisions of Washington Administrative Code 173-303 and by the Hazardous and Solid Waste Amendments. For ease of reference, the alpha-numeric section identifiers from the Washington State Department of Ecology's permit application guidance documentation follow, in brackets, the chapter headings and subheadings. Documentation contained in the General Information Portion is broader in nature and could be used by multiple treatment, storage, and/or disposal units (i.e., either 'operating' units, units 'undergoing closure', or units being 'dispositioned through other options'). A checklist indicating where information is contained in the General Information Portion, in relation to the Washington State Department of Ecology guidance documentation, is located in the Contents Section.

The intent of the General Information Portion is: (1) to provide an overview of the Hanford Facility; and (2) to assist in streamlining efforts associated with treatment, storage, and/or disposal unit-specific Part B permit application, preclosure work plan, closure work plan, closure plan, closure/postclosure plan, or postclosure permit application documentation development, and the Hanford Facility Resource Conservation and Recovery Act Permit modification process. Wherever appropriate, the Unit-Specific Portion of the application, as well as preclosure work plan, closure work plan, closure plan, closure/postclosure plan, or postclosure permit application documentation, will make cross-reference to the General Information Portion, rather than duplicating text. Thus, Hanford Facility Resource Conservation and Recovery Act Permit modifications involving general information will require updating only the General Information Portion instead of each unit-specific document.

'Dangerous Waste', as used in the title of the Hanford Facility Dangerous Waste Permit Application, refers to waste subject to Washington Administrative Code 173-303 requirements and to requirements of the Hazardous and Solid Waste Amendments, including those for which the state of Washington has not yet been granted authority by the U.S. Environmental Protection Agency. Throughout the Hanford Facility Dangerous Waste Permit Application, 'mixed waste' refers to waste containing both dangerous and radioactive components. The radioactive component of mixed waste is interpreted by the U.S. Department of Energy to be regulated under the Atomic Energy Act; the nonradioactive dangerous component of mixed waste is interpreted to be regulated under the Resource Conservation and Recovery Act and Washington 
1 Administrative Code 173-303. It is the position of the U.S. Department of Energy that any procedures, 2 methods, data, or information contained in the Hanford Facility Dangerous Waste Permit Application that

3 relate solely to the radioactive component of mixed waste are outside the scope of the permit application and 4 the Hanford Facility Resource Conservation and Recovery Act Permit, but are included for the sake of 5 completeness. It is the position of the Washington State Department of Ecology that the radioactive 6 component influences safe management of mixed waste and therefore information about this component is 7 necessary to ensure compliance with Washington Administrative Code 173-303 and the Hanford Facility

8 Resource Conservation and Recovery Act Permit. Both agencies acknowledge the other's position, but to 9 avoid a conflict on the issue, the U.S. Department of Energy, Richland Operations Office has agreed to 10 provide information on radioactive constituents without agreeing with the Washington State Department of 11 Ecology's position. The Washington State Department of Ecology has agreed to accept the information in 12 this context without giving up its position.

Revision 4 of the General Information Portion of the Hanford Facility Dangerous Waste Permit Application contains information current as of May 1, 1998. This document is a complete submittal and 16 supersedes Revision 3. 
DOE/RL-91-28, Rev. 4

05/98

This page intentionally left blank. 


\section{DOCUMENT CONTENTS}

FOREWORD

CHECKLIST

1.0 PART A [A]

2.0 FACILITY DESCRIPTION AND GENERAL PROVISIONS [B AND E]

3.0 WASTE ANALYSIS [C]

4.0 PROCESS INFORMATION [D]

5.0 GROUNDWATER MONITORING FOR LAND-BASED UNITS [D-10]

6.0 PROCEDURES TO PREVENT HAZARDS [F]

7.0 CONTINGENCY PLAN [G]

8.0 PERSONNEL TRAINING $[\mathrm{H}]$

9.0 EXPOSURE INFORMATION REPORT

10.0 WASTE MINIMIZATION [D-9]

11.0 CLOSURE AND FINANCLAL ASSURANCE []

12.0 REPORTING AND RECORDKEEPING

13.0 OTHER FEDERAL AND STATE LAWS [J]

14.0 CERTIFICATION $[\mathrm{K}]$

15.0 REFERENCES

\section{APPENDICES}

46 2C HANFORD FACILITY LEGAL DESCRIPTION 
DOE/RL-91-28, Rev. 4

$05 / 98$

This page intentionally left blank. 
In accordance with the Washington State Department of Ecology's Dangerous Waste Permit Application Requirements (Ecology 1996), an application checklist has been completed by providing the facility name and indicating where the listed material has been placed in the General Information Portion. This is particularly important when the General Information Portion does not closely follow the outline of the checklist and guidance or to designate where information is more appropriately placed in the Unit-Specific Portion. The completed checklist is contained within this section of this Dangerous Waste Permit application documentation.

As noted in the Introduction of the Washington State Department of Ecology's 1996 guidance document, this document only includes a detailed discussion of requirements for treatment and storage in tanks and containers. Requirements for land-based and incinerator units are in a document entitled Dangerous Waste Management Facility Permit Application: Additional Requirements for Facilities Which Dispose of Dangerous Wastes or Manage Them in Land-based Units (Ecology 1987). The 1996 guidance document advises that when preparing an application for land-based units use both guidance documents in conjunction. To provide continuity in numbering, the major outline headings for land-based and incinerator units have been provided by the Washington State Department of Ecology in the application checklist included in its 1996 guidance document.

The application checklist provided by the Washington State Department of Ecology has been modified to include citations for Chapter 173-303 Washington Administrative Code and for 40 Code of Federal Regulations Parts 264 and 270 . In addition, the title of the checklist has been modified to indicate that the checklist contents do not just refer to "Treatment and Storage in Tanks and Containers". 
Facility Name Hanford Facility Dangerous Waste Permit Application, General Information Portion

Date Application Received

\begin{tabular}{|c|c|c|c|}
\hline \multicolumn{4}{|c|}{$\begin{array}{l}\text { State of Washington } \\
\text { Part B Permit Application Review Checklist }\end{array}$} \\
\hline & & $\begin{array}{l}\text { Technically } \\
\text { Adequate? }\end{array}$ & Location in Application \\
\hline \multicolumn{4}{|c|}{$\begin{array}{l}\text { Citations for the Chapter 173-303 Washington Administrative Code (WAC) are followed by those for } 40 \\
\text { Code of Federal Regulations (CFR) Parts } 264 \text { and } 270 \text {. The federal citations are always in brackets. For } \\
\text { example: "806(2)[270.10(d)]" refers to WAC 173-303-806(2) and } 40 \text { CFR } 270.10 \text { (d). }\end{array}$} \\
\hline A. & $\begin{array}{l}\text { Part A Form } \\
806(2), 810(12)(a), 810(13)[270.10(d) \\
270.11(a) \text { and }(d), 270.13]\end{array}$ & & Chapter 1.0 \\
\hline B. & $\begin{array}{l}\text { Facility Description and General } \\
\text { Provisions } \\
806(4)(\mathrm{a})(\mathrm{i}),(\mathrm{x}),(\mathrm{xi}),(\mathrm{xviii}) \\
{[270.14(\mathrm{~b})(1),(10),(19)]}\end{array}$ & & Chapter 2.0 \\
\hline B-1 & $\begin{array}{l}\text { General Description } \\
806(4)(a)(i)[270.14(b)(1)]\end{array}$ & & 2.1 \\
\hline B-1(a) & Facility Description & & 2.1 .1 \\
\hline B-1(b) & Construction Schedule & & 2.1 .2 \\
\hline $\mathrm{B}-2$ & Topographic Map & & 2.2 \\
\hline B-2a & $\begin{array}{l}\text { General Requirements } \\
806(4)(\mathrm{a}) \text { (xviii) [270.14(b)(19)] }\end{array}$ & & 2.2 .1 \\
\hline B-2b & $\begin{array}{l}\text { Additional Requirements for Land } \\
\text { Disposal Facilities }\end{array}$ & & 2.2 .2 \\
\hline B-3 & $\begin{array}{l}\text { Seismic Consideration } \\
806(4)(\mathrm{a})(\mathrm{xi})[270.14(\mathrm{~b})(11)(\mathrm{i}) \text { and (ii), } \\
264.18(\mathrm{a})]\end{array}$ & & 2.3 \\
\hline B-4 & $\begin{array}{l}\text { Traffic Information } \\
806(4)(a)(x)[270.14(b)(10)]\end{array}$ & & 2.4 \\
\hline C. & $\begin{array}{l}\text { Waste Analysis } \\
806(4) \text { (a)(ii) and (iii), } 300[270.14(3) \\
264.13(\text { b) and (c)] }\end{array}$ & & Chapter 3.0 \\
\hline
\end{tabular}




\begin{tabular}{|c|c|c|c|}
\hline & & $\begin{array}{l}\text { Technically } \\
\text { Adequate? }\end{array}$ & Location in Application \\
\hline C-I & $\begin{array}{l}\text { Chemical, Biological and Physical } \\
\text { Analyses } \\
806(4)(\mathrm{a})(\mathrm{ii}), 806(4)(\mathrm{b})(\mathrm{ii}) \text { and }(\mathrm{v}) ; \\
806(4)(\mathrm{c})(\mathrm{x}) ; 140 ; 300 ; 395 ; 630(7)(\mathrm{c}) \\
\text { and }(9) ; 640(1)(\mathrm{b}),(2)(\mathrm{c}),(3)(\mathrm{a}), \text { and } \\
(10)[270.14(\mathrm{~b})(2), 264.13(\mathrm{a}), 268.7 \\
268.9]\end{array}$ & & 3.1 \\
\hline $\begin{array}{l}\text { C-1a } \\
\text { C-1b } \\
\text { C-1c }\end{array}$ & $\begin{array}{l}\text { Waste In Piles } \\
\text { Landfilled Wastes } \\
\text { Wastes Incinerated and Wastes Used in } \\
\text { Performance Tests }\end{array}$ & & $\begin{array}{l}3.1 .3 \\
3.1 .4 \\
3.1 .5\end{array}$ \\
\hline $\mathrm{C}-2$ & $\begin{array}{l}\text { Waste Analysis Plan } \\
806(4)(\mathrm{a})(\mathrm{iii}), 140,300(5) \text { and (6) } \\
{[270.14(\mathrm{~b})(3), 264.13(\mathrm{~b}) \text { and (c), } 268.7} \\
\text { and 268.9] }\end{array}$ & & 3.2 \\
\hline$C-2 a$ & $\begin{array}{l}\text { Detailed Chemical, Physical, and/or } \\
\text { Biological Analysis }\end{array}$ & & 3.2 \\
\hline $\mathrm{C}-2 \mathrm{a}(1)$ & $\begin{array}{l}\text { Parameters and Rationale } \\
\text { 806(4)(b)(ii)(A); } 140(\mathrm{LDR}) ; 300(2), \\
\quad(5)(\mathrm{a}), \text { and (5)(f); 395(1) and (2); } \\
\text { 630(7)(c); 640(1)(b), (2)(c) and (3)(a) } \\
\text { [270.15(b)(1), 270.24, 270.25, } \\
\text { 264.13(b)(1) and (8), 264.17, } \\
\text { 264.191(b)(2), 264.192(a)(2), } \\
\text { 264.1034(d),264.1064(d),268.7] }\end{array}$ & & 3.2 \\
\hline $\mathrm{C}-2 \mathrm{a}(2)$ & $\begin{array}{l}\text { Analytical Methods } \\
110,300(5)(\mathrm{b})[264.13(\mathrm{~b})(2) \text { and }(8) \\
\text { Part } 264 \text { Subparts AA, BB, and } \\
\text { CC] - Washington State has not adopted } \\
\text { the CC requirements yet. }\end{array}$ & & 3.2 \\
\hline $\mathrm{C}-2 \mathrm{a}(3)$ & $\begin{array}{l}\text { Generator-Supplied Analyses } \\
300(3),(5)(\mathrm{g}) \text {, and (e) }[264.13(\mathrm{~b})(5)]\end{array}$ & & 3.2 \\
\hline$C-2 b$ & $\begin{array}{l}\text { Additional Requirements for Wastes } \\
\text { Generated Off-site } \\
806(4) \text { (a)(iii), 300(6) }[264.13 \text { (c)] }\end{array}$ & & 3.2 \\
\hline
\end{tabular}




\begin{tabular}{|c|c|c|c|}
\hline & & $\begin{array}{l}\text { Technically } \\
\text { Adequate? }\end{array}$ & Location in Application \\
\hline$C-2 b(1)$ & $\begin{array}{l}\text { Parameters and Rationale to Confirm Identity } \\
\text { of Off-site Waste } \\
300(3),(5)(\mathrm{a}) \text {, and } 5(\mathrm{~g})[264.13(\mathrm{a})(4) \\
\text { and (b)(1)] }\end{array}$ & & 3.2 \\
\hline $\mathrm{C}-2 \mathrm{~b}(2)$ & $\begin{array}{l}\text { Analytical Methods to Confirm Identity of } \\
\text { Off-site Waste } \\
300(3) \text { and }(5)(b)[264.13(b)(2)]\end{array}$ & & 3.2 \\
\hline $\mathrm{C}-2 \mathrm{~b}(3)$ & $\begin{array}{l}\text { Representative Sampling of Incoming Off- } \\
\text { site Wastes } \\
300(3) \text { and }(5)(c), 110(2)[264.13(b)(3), \\
\text { Part 261, Appendix l] }\end{array}$ & & 3.2 \\
\hline $\mathrm{C}-2 \mathrm{c}$ & $\begin{array}{l}\text { Methods for Collecting Samples for } \\
\text { Detailed and Confirming Analyses } \\
300(5)(c), 110(2)[264.13(b)(3) \\
\text { 264.1034(d), Part 261, Appendix I] }\end{array}$ & & 3.2 \\
\hline$C-2 d$ & $\begin{array}{l}\text { Frequency of Analyses } \\
300(4),(5)(d)[264.13(b)(4)]\end{array}$ & & 3.2 \\
\hline$C-3$ & $\begin{array}{l}\text { Manifest System } \\
370[264.71,264.72]\end{array}$ & & 3.3 \\
\hline$C-3 a$ & $\begin{array}{l}\text { Procedures for Receiving Shipments } \\
370(2),(3),(4)[264.71]\end{array}$ & & 3.3 .1 \\
\hline $\mathrm{C}-3 \mathrm{~b}$ & $\begin{array}{l}\text { Response to Significant Discrepancies } \\
370(4)[264.72]\end{array}$ & & 3.3 .2 \\
\hline $\mathrm{C}-3 \mathrm{c}$ & $\begin{array}{l}\text { Provisions for Non-acceptance of } \\
\text { Shipment } \\
370(5)\end{array}$ & & 3.3 .3 \\
\hline $\mathrm{C}-3 \mathrm{c}(1)$ & $\begin{array}{l}\text { Non-acceptance of Undamaged Shipment } \\
370(5)(b)\end{array}$ & & 3.3.3.1 \\
\hline $\mathrm{C}-3 \mathrm{c}(2)$ & $\begin{array}{l}\text { Activation of Contingency Plan for Damaged } \\
\text { Shipment } \\
370(5)(c)\end{array}$ & & 3.3 .3 .2 \\
\hline $\mathrm{C}-4$ & $\begin{array}{l}\text { Tracking System } \\
380\end{array}$ & & 3.4 \\
\hline
\end{tabular}




\begin{tabular}{|c|c|c|c|}
\hline D. & $\begin{array}{l}\text { Process Information } \\
806(4)(\mathrm{b})-(\mathrm{c}), 630 \text { through } 670 \\
{[270.15-270.26,264 \text { Subparts I - BB] }}\end{array}$ & $\begin{array}{l}\text { Technically } \\
\text { Adequate? }\end{array}$ & $\begin{array}{l}\text { Location in Application } \\
\text { Chapter } 4.0\end{array}$ \\
\hline $\mathrm{D}-1$ & $\begin{array}{l}\text { Containers } \\
806(4)(b), 630[270.15,264 \text { Subpart I] }\end{array}$ & & 4.2 \\
\hline D-la & $\begin{array}{l}\text { Description of Containers } \\
630(4) \text { [264.172] }\end{array}$ & & Unit-Specific Portion \\
\hline D-1b & $\begin{array}{l}\text { Container Management Practices } \\
630(5) \text { and }(8) ; 340(3) \text { [264.35, } \\
264.173]\end{array}$ & & Unit-Specific Portion \\
\hline D-lc & $\begin{array}{l}\text { Container Labelling } \\
806(4)(b)(i i i), 395(6), 630(3)\end{array}$ & & Unit-Specific Portion \\
\hline D-1d & $\begin{array}{l}\text { Containment Requirements for Storing } \\
\text { Containers }\end{array}$ & & Unit-Specific Portion \\
\hline $\mathrm{D}-1 \mathrm{~d}(1) \mathrm{Se}$ & $\begin{array}{l}\text { Secondary Containment System Design } \\
\text { 806(4)(b)(i) and (iv), 630(7) [270.15(a); } \\
\text { 264.175(a), (b), and (d)] }\end{array}$ & & Unit-Specific Portion \\
\hline$D-1 d(1)(a)$ & $\begin{array}{l}\text { System Design } \\
806(4)(b)(\mathrm{i}), 630(7) \text { (a) and (d) } \\
{[270.15(\mathrm{a}), 264.175(\mathrm{~b})]}\end{array}$ & & Unit-Specific Portion \\
\hline$D-\operatorname{ld}(1)(b)$ & $\begin{array}{l}\text { Structural Integrity of Base } \\
806(4)(\mathrm{b})(\mathrm{i}), 630(7)(\mathrm{a})[270.15(\mathrm{a}) \\
264.175(\mathrm{~b})]\end{array}$ & & Unit-Specific Portion \\
\hline$D-\operatorname{ld}(1)(\mathrm{c})$ & $\begin{array}{l}\text { Containment System Capacity } \\
806(4)(\mathrm{b})(\mathrm{i})(\mathrm{A}) \text { and }(\mathrm{C}), 630(7)(\mathrm{a}) \\
{[270.15(\mathrm{a})(3), 264: 175(\mathrm{~b})(3)]}\end{array}$ & & Unit-Specific Portion \\
\hline D-1d(1)(d) & $\begin{array}{l}\text { Control of Run-on } \\
806(4)(\mathrm{b})(\mathrm{i})(\mathrm{D}), 630(7)(\mathrm{b}) \\
{[270.15(\mathrm{a})(4), 264.175(\mathrm{~b})(4)]}\end{array}$ & & Unit-Specific Portion \\
\hline $\begin{array}{l}\text { D-1d(2) } \mathrm{Re} \\
\mathrm{Sy}\end{array}$ & $\begin{array}{l}\text { Removal of Liquids from Containment } \\
\text { yystem } \\
806(4)(\mathrm{b})(\mathrm{i})(\mathrm{E}), 630(7)(\mathrm{a})(\mathrm{ii}) \\
{[270.15(\mathrm{a})(5), 264.175(\mathrm{~b})(5)]}\end{array}$ & & Unit-Specific Portion \\
\hline
\end{tabular}




\begin{tabular}{|c|c|c|c|}
\hline & & $\begin{array}{l}\text { Technically } \\
\text { Adequate? }\end{array}$ & Location in Application \\
\hline D-le & $\begin{array}{l}\text { Demonstration that Containment Is Not } \\
\text { Required Because Containers Do Not } \\
\text { Contain Free Liquids, Wastes That } \\
\text { Exhibit Ignitability or Reactivity, or } \\
\text { Wastes Designated F020 - 023, F026, or } \\
\text { F027 } \\
806(4)(b)(i i), 630(7)(c)[270.15(b)(2) \text {, } \\
264.175(c)]\end{array}$ & & Unit-Specific Portion \\
\hline D-lf & $\begin{array}{l}\text { Prevention of Reaction of Ignitable, } \\
\text { Reactive, and Incompatible Wastes in } \\
\text { Containers }\end{array}$ & & Unit-Specific Portion \\
\hline D-1f(1) & $\begin{array}{l}\text { Management of Certain Reactive Wastes in } \\
\text { Containers } \\
806(4)(\mathrm{b})(\mathrm{iv}), 630(8) \text { (a) }[270.15 \text { (c), } \\
264.176]\end{array}$ & & Unit-Specific Portion \\
\hline D-1f(2) & $\begin{array}{l}\text { Management of Ignitable and Certain Other } \\
\text { Reactive Wastes in Containers } \\
806(4)(\mathrm{b})(\mathrm{iv}), 630(8)(\mathrm{b})[270.15(\mathrm{c}) \\
264.176]\end{array}$ & & Unit-Specific Portion \\
\hline D-lf(3) & $\begin{array}{l}\text { Design of Areas to Manage Incompatible } \\
\text { Wastes } \\
806(4)(\text { b) (iv), 630(9)(c) [270.15(c), } \\
264.177]\end{array}$ & & Unit-Specific Portion \\
\hline D-2 & $\begin{array}{l}\text { Tank Systems } \\
806(4)(\mathrm{c}), 640,395(6)[270.16,264.190 \\
\text { through 264.199, 264.1030 through } \\
264.1065]\end{array}$ & & 4.3 \\
\hline$D-2 a$ & $\begin{array}{l}\text { Design, Installation and Assessment of } \\
\text { Tanks Systems } \\
806(4)(\mathrm{c})(\mathrm{i}),(\mathrm{ii}),(\mathrm{v}) \text {, and (vi), 640(2) and } \\
\text { (3) [270.16(a), (b), (e), and (f), 264.191, } \\
264.192]\end{array}$ & . & Unit-Specific Portion \\
\hline$D-2 a(1)$ & $\begin{array}{l}\text { Design Requirements } \\
\text { 640(2)(c), (3)(a) [264.191(b), } \\
\text { 264.192(a)] }\end{array}$ & & Unit-Specific Portion \\
\hline
\end{tabular}




\begin{tabular}{|c|c|c|c|}
\hline & & $\begin{array}{l}\text { Technically } \\
\text { Adequate? }\end{array}$ & Location in Application \\
\hline D-2a(2) In & $\begin{array}{l}\text { Integrity Assessments } \\
640(2)(\mathrm{a}),(\mathrm{c}) \text { and }(\mathrm{e}) ;(3)(\mathrm{a}),(\mathrm{b}) \text { and }(\mathrm{g}) \\
{[264.191(\mathrm{a}) \text { and }(\mathrm{b}) 264.192(\mathrm{a}),(\mathrm{b}) \text {, and }} \\
(\mathrm{g})]\end{array}$ & & Unit-Specific Portion \\
\hline $\mathrm{D}-2 \mathrm{a}(3) \mathrm{A}$ & $\begin{array}{l}\text { Additional Requirements for Existing Tanks } \\
640(2)(a) \text { and (c)(v) [264.191(a) and } \\
\text { (b)(5)] }\end{array}$ & & Unit-Specific Portion \\
\hline D-2a(4) A & $\begin{array}{l}\text { Additional Requirements for New Tanks } \\
640(3)(\mathrm{c}),(\mathrm{e}),(\mathrm{f}) \text { and }(\mathrm{g}) \\
{[264.192(\mathrm{~b}),(\mathrm{d}) \text {, and }(\mathrm{e})]} \\
\end{array}$ & & Unit-Specific Portion \\
\hline $\begin{array}{rr}\mathrm{D}-2 \mathrm{a}(5) & \mathrm{A} \\
& \text { or } \\
& \\
& \end{array}$ & $\begin{array}{l}\text { Additional Requirements for New On-ground } \\
\text { or Underground Tanks } \\
640(3)(\mathrm{a})(\mathrm{iii}),(\mathrm{iv}) \text {, and (v); } 640(3)(\mathrm{d}) \\
{[264.192(\mathrm{a})(3),(4) \text {, and (5), and (c)] }}\end{array}$ & & Unit-Specific Portion \\
\hline $\mathrm{D}-2 \mathrm{~b}$ & $\begin{array}{l}\text { Secondary Containment and Release } \\
\text { Detection for Tank Systems } \\
640(4), 806(4)(\mathrm{c})(\text { vii) }[270.16(\mathrm{~g}) \\
264.193]\end{array}$ & & Unit-Specific Portion \\
\hline D- $2 \mathrm{~b}(1) \mathrm{R}$ & Requirements for All Tank Systems & & Unit-Specific Portion \\
\hline $\begin{array}{r}\mathrm{D}-2 \mathrm{~b}(2) \mathrm{A} \\
\text { of }\end{array}$ & $\begin{array}{l}\text { Additional Requirements for Specific Types } \\
\text { of Systems }\end{array}$ & & Unit-Specific Portion \\
\hline $\mathrm{D}-2 \mathrm{~b}(2)(\mathrm{a})$ & $\begin{array}{l}\text { a) Vault Systems } \\
\text { 640(4)(e)(ii) }[264.193(\mathrm{e})(2)]\end{array}$ & & Unit-Specific Portion \\
\hline$D-2 b(2)(b)$ & $\begin{array}{l}\text { b) Double-walled Tanks } \\
640(4)(\mathrm{e})(\mathrm{iii})[264.193(\mathrm{e})(3)]\end{array}$ & & Unit-Specific Portion \\
\hline$D-2 b(2)(c)$ & $\begin{array}{l}\text { c) Ancillary Equipment } \\
640(4)(f)[264.193(f)]\end{array}$ & & Unit-Specific Portion \\
\hline D-2c & $\begin{array}{l}\text { Variances from Secondary Containment } \\
\text { Requirements } \\
640(4)(\mathrm{g}) \text { and }(\mathrm{h}), 640(\mathrm{l})(\mathrm{b}) \text { and } \\
806(\mathrm{c})(\mathrm{viii})[270.16(\mathrm{~h}), 264.193(\mathrm{~g}) \text { and } \\
\text { (h), 264.190(a)] }\end{array}$ & & Unit-Specific Portion \\
\hline
\end{tabular}




\begin{tabular}{|c|c|c|c|}
\hline & & $\begin{array}{l}\text { Technically } \\
\text { Adequate? }\end{array}$ & Location in Application \\
\hline D-2d & $\begin{array}{l}\text { Tank Management Practices } \\
806(4)(\mathrm{c})(\text { iii), (iv),(ix); 640(5)(a) and (b) } \\
{[270.16(\mathrm{c}),(\mathrm{d}) \text {, and (i), 264.194(a) and }} \\
\text { (b)] }\end{array}$ & & Unit-Specific Portion \\
\hline$D-2 e$ & $\begin{array}{l}\text { Labels or Signs } \\
806(4)(\mathrm{c})(\mathrm{xi}), 395(6), 640(5)(\mathrm{d})\end{array}$ & & Unit-Specific Portion \\
\hline$D-2 f$ & $\begin{array}{l}\text { Air Emissions } \\
806(4)(\mathrm{c})(\mathrm{xii}), 640(5)(\mathrm{e})\end{array}$ & & Unit-Specific Portion \\
\hline D-2g & $\begin{array}{l}\text { Management of Ignitable or Reactive } \\
\text { Wastes in Tank Systems } \\
806(4)(c)(x), 640(9)[270.16(f) \\
264.198]\end{array}$ & & Unit-Specific Portion \\
\hline $\mathrm{D}-2 \mathrm{~h}$ & $\begin{array}{l}\text { Management of Incompatible Wastes in } \\
\text { Tank Systems } \\
\text { 806(4)(c)(x),640(10) [270.16(f), } \\
264.199]\end{array}$ & & Unit-Specific Portion \\
\hline $\begin{array}{l}D-3 \\
D-4 \\
D-5 \\
D-6 \\
D-7\end{array}$ & $\begin{array}{l}\text { Waste Piles } \\
\text { Surface Impoundments } \\
\text { Incinerators } \\
\text { Landfills } \\
\text { Land Treatment } \\
\end{array}$ & & $\begin{array}{l}4.4 \\
4.5 \\
4.6 \\
4.7 \\
4.8 \\
\end{array}$ \\
\hline D-8 & $\begin{array}{l}\text { Air Emissions Control } \\
806(4)(j) \text { and }(\mathrm{k}), 110 \text { (test methods), } \\
690,691[270.24,270.25, \text { Part } 264 \\
\text { Subparts AA, BB, and CC] - } \\
\text { Washington State has not adopted the } \\
\text { CC requirements yet. }\end{array}$ & & 4.10 \\
\hline D-8a & $\begin{array}{l}\text { Process Vents } \\
806(4)(j), 110,690 \text { [270.24, } \\
264.1030-264.1035 \text { (Subpart AA)] }\end{array}$ & & 4.10 .1 \\
\hline $\mathrm{D}-8 \mathrm{a}(1)$ & $\begin{array}{l}\text { Applicability of-Subpart AA. Standards } \\
\quad 690[270.24(\mathrm{~b}), 264.1030,264.1034(\mathrm{~d}) \\
264.1035(\mathrm{~b})(2)]\end{array}$ & & 4.10 .1 \\
\hline
\end{tabular}




\begin{tabular}{|c|c|c|c|}
\hline & & $\begin{array}{l}\text { Technically } \\
\text { Adequate? }\end{array}$ & Location in Application \\
\hline D-8a(1)(a) & $\begin{array}{l}\text { Process Vents Subject to Subpart AA } \\
\text { Standards }\end{array}$ & & 4.10 .1 \\
\hline$D-8 a(1)(b)$ & $\begin{array}{l}\text { Process Vents Not Subject to Subpart } \\
\text { AA Standards }\end{array}$ & & 4.10 .1 \\
\hline$D-8 a(1)(c)$ & $\begin{array}{l}\text { Re-evaluating Applicability of Subpart } \\
\text { AA Standards } \\
690[270.24(\mathrm{~b})(3), 264.1030]\end{array}$ & & 4.10 .1 \\
\hline D-8a(2) Prc & $\begin{array}{l}\text { rocess Vents - Demonstrating Compliance } \\
806(4)(\mathrm{j}), 110,690[270.24,264.1030 \text { - } \\
264.1035]\end{array}$ & & 4.10 .1 \\
\hline $\mathrm{D}-8 \mathrm{a}(2)(\mathrm{a})$ & $\begin{array}{l}\text { The Basis for Meeting Limits/ } \\
\text { Reductions } \\
806(4)(\mathrm{j})(\mathrm{ii}), 110,690[270.24(\mathrm{~b}) \text {, } \\
264.1032,264.1034(\mathrm{c}), 264.1035(\mathrm{~b})(2) \\
\text { and (b)(3)] }\end{array}$ & & 4.10.1 \\
\hline $\mathrm{D}-8 \mathrm{a}(2)(\mathrm{b})$ & $\begin{array}{l}\text { Demonstrating Compliance via Selected } \\
\text { Method } \\
806(4)(\mathrm{j})(\mathrm{ii}), 110,690[270.24(\mathrm{~b}) \\
264.1032,264.1034(\mathrm{c}), 264.1035(\mathrm{~b})(2) \\
\text { and (b)(3)] }\end{array}$ & & 4.10 .1 \\
\hline $\mathrm{D}-8 \mathrm{a}(2)(\mathrm{c})$ & $\begin{array}{l}\text { Design Information and Operating } \\
\text { Parameters for Closed Vent Systems and } \\
\text { Control Devices } \\
806(4)(j)(i v), 110,690[270.24(\text { d), } \\
264.1032(\text { b), 264.1033, 264.1034, } \\
264.1035(\text { b) }(3) \text { and (b)(4), 264.1035(c)] }\end{array}$ & & 4.10 .1 \\
\hline $\mathrm{D}-8 \mathrm{a}(2)(\mathrm{d})$ & $\begin{array}{l}\text { Re-evaluating Compliance with Subpart } \\
\text { AA Standards } \\
806(4)(j)(i i), 690[270.24(\text { b) }, 264.1030 \text {, } \\
264.1035(\text { b) }(2)]\end{array}$ & & 4.10 .1 \\
\hline D-8b & $\begin{array}{l}\text { Equipment:Leaks } \\
806(4)(\mathrm{k}), 110,691[270.25, \\
264.1050-264.1064,264.1033, \\
264.1034(\mathrm{c}), 264.1035(\mathrm{~b}) \text { and (c)] }\end{array}$ & & 4.10 .2 \\
\hline \multicolumn{2}{|c|}{$\begin{array}{l}\text { D-8b(1) Applicability of Subpart BB Standards } \\
806(4)(\mathrm{k}), 110,691[270.25,264.1050, \\
264.1063]\end{array}$} & & 4.10 .2 \\
\hline
\end{tabular}




\begin{tabular}{|c|c|c|c|}
\hline & & $\begin{array}{l}\text { Technically } \\
\text { Adequate? }\end{array}$ & Location in Application \\
\hline$D-8 b(1)(a)$ & Equipment Subject to Subpart BB & & 4.10 .2 \\
\hline $\mathrm{D}-8 \mathrm{~b}(\mathrm{l})(\mathrm{b})$ & $\begin{array}{l}\text { Re-evaluating Applicability of Subpart } \\
\text { BB Standards } \\
110,691(1)[264.1063(\mathrm{~d})-(\mathrm{g}) \\
264.1064(\mathrm{k})]\end{array}$ & & 4.10 .2 \\
\hline \multicolumn{2}{|c|}{$\begin{array}{l}\text { D-8b(2) Equipment Leaks - Demonstrating } \\
\text { Compliance }\end{array}$} & & 4.10 .2 \\
\hline . & $\begin{array}{l}\text { Procedures for Identifying Equipment } \\
\text { Location and Method of Compliance, } \\
\text { Marking Equipment, and Ensuring } \\
\text { Records are Up-to-date } \\
806(4)(\mathrm{k}), 691 \text { [270.25, 264.1050 - } \\
264.1064]\end{array}$ & & 4.10 .2 \\
\hline$D-8 b(2)(b)$ & $\begin{array}{l}\text { Demonstrating Compliance with } \\
\text { D-8b(1)(a) and (2)(a) Procedures } \\
806(4)(\mathrm{k}), 691[270.25,264.1050 \text { - } \\
264.1059]\end{array}$ & & 4.10 .2 \\
\hline$D-8 b(2)(c)$ & $\begin{array}{l}\text { Closed Vent Systems or Control Devices: } \\
\text { Showing Compliance with Emission } \\
\text { Reduction Standards } \\
\text { 806(4)(k), 110,690,691 [270.25, } \\
264.1033-264.1035 \\
264.1052-264.1055,264.1059 \\
264.1060,264.1063]\end{array}$ & & 4.10 .2 \\
\hline D-8c & $\begin{array}{l}\text { Tanks and Containers } \\
{[270.27,270.15,270.16 \text {, Part } 264} \\
\text { Subpart CC] }\end{array}$ & & 4.10 .3 \\
\hline $\mathrm{D}-8 \mathrm{c}(1) \mathrm{Ap}$ & $\begin{array}{l}\text { pplicability of Subpart CC Standards } \\
{[264.1080,264.1082]}\end{array}$ & & 4.10 .3 \\
\hline $\begin{array}{r}\mathrm{D}-8 \mathrm{c}(2) \mathrm{Ta} \\
\mathrm{De} \\
\end{array}$ & $\begin{array}{l}\text { ank Systems and Container Areas - } \\
\text { emonstrating Compliance } \\
\text { Provide the documentation required by } \\
\$ 270.27(\text { a) }(1)-(a)(3) \text { and }(a)(5)-(a)(6)\end{array}$ & & 4.10 .3 \\
\hline & $\begin{array}{l}\text { Waste Minimization } \\
{[264.73(\mathrm{~b})(9), 264.75(\mathrm{~h}) \text { and }(\mathrm{i})]}\end{array}$ & & Chapter 10.0 \\
\hline
\end{tabular}




\begin{tabular}{|c|c|c|c|}
\hline & & $\begin{array}{l}\text { Technically } \\
\text { Adequate? }\end{array}$ & Location in Application \\
\hline D-10 & $\begin{array}{l}\text { Groundwater Monitoring for Land-based } \\
\text { Units }\end{array}$ & & Chapter 5.0 \\
\hline E. & $\begin{array}{l}\text { Releases from Solid Waste } \\
\text { Management Units } \\
\text { 806(4)(a)(xxiii) and (xxiv), 645, } 646 \\
{[270.14(\text { d)] }}\end{array}$ & & Chapter 2.0 \\
\hline E-1 & $\begin{array}{l}\text { Solid Waste Management Units and } \\
\text { Known and Suspected Releases of } \\
\text { Dangerous Wastes or Constituents }\end{array}$ & & 2.5 \\
\hline E-1a & Solid Waste Management Units & & 2.5 \\
\hline$E-1 b$ & Releases & & 2.5 \\
\hline $\mathrm{E}-2$ & $\begin{array}{l}\text { Corrective Actions Implemented } \\
\text { (If you have been conducting corrective } \\
\text { action under a RCRA Section 3008(h), } \\
7003 \text {, or } 3013 \text { order; under a Model } \\
\text { Toxics Control Act (MTCA) order; as an } \\
\text { independent MTCA cleanup; or under } \\
\text { another authority.) }\end{array}$ & & 2.5 \\
\hline F. & $\begin{array}{l}\text { Procedures to Prevent Hazards } \\
\text { 806(4)(a)(iv),(v),(vi),(viii),(ix), 310, } \\
320,340[270.14(\mathrm{~b})(4),(5),(6),(8) ; \\
264.14,264.15,264.17,264.30- \\
264.35]\end{array}$ & & Chapter 6.0 \\
\hline F-1 & $\begin{array}{l}\text { Security } \\
806(4)(\mathrm{a})(\mathrm{iv}), 310(1) \text { and (2) } \\
{[270.14(\mathrm{~b})(4), 264.14]}\end{array}$ & & 6.1 \\
\hline F-1a & $\begin{array}{l}\text { Security Procedures and Equipment } \\
806(4)(\mathrm{a})(\mathrm{iv}), 310(2)[270.14(\mathrm{~b})(4), \\
264.14]\end{array}$ & & 6.1 .1 \\
\hline$F-1 b$ & $\begin{array}{l}\text { Waiver } \\
310(1)[264.14(a)]\end{array}$ & & 6.1 .2 \\
\hline $\mathrm{F}-2$ & $\begin{array}{l}\text { Inspection Plan } \\
806(4)(\mathrm{a})(\mathrm{v}), 320,340[270.14(\mathrm{~b})(5) \\
264.15]\end{array}$ & & 6.2 \\
\hline
\end{tabular}




\begin{tabular}{|c|c|c|c|}
\hline & & $\begin{array}{l}\text { Technically } \\
\text { Adequate? }\end{array}$ & Location in Application \\
\hline$F-2 a$ & $\begin{array}{l}\text { General Inspection Requirements } \\
806(4)(\mathrm{a})(\mathrm{v}), 320(1), 320(2)(\mathrm{a}),(\mathrm{b}) \text { and } \\
\text { (c), 340(1)(d) }[270.14(\mathrm{~b})(5), 264.15(\mathrm{a}) \\
\text { and (b),264.33,264.34,264.35] }\end{array}$ & & 6.2 .1 \\
\hline$F-2 b$ & $\begin{array}{l}\text { Inspection Log } \\
320(2)(d)[264.15(d)]\end{array}$ & & 6.2 .2 \\
\hline$F-2 c$ & $\begin{array}{l}\text { Schedule for Remedial Action for } \\
\text { Problems Revealed } \\
320(3)[264.15(\mathrm{c})]\end{array}$ & & 6.2 .3 \\
\hline $\mathrm{F}-2 \mathrm{~d}$ & $\begin{array}{l}\text { Specific Process or Waste Type } \\
\text { Inspection Requirements }\end{array}$ & & 6.2 .4 \\
\hline $\mathrm{F}-2 \mathrm{~d}(1)$ & $\begin{array}{l}\text { Container Inspections } \\
806(4)(\mathrm{a})(\mathrm{v}), 630(3) \text { and }(6), 320(2)(\mathrm{c}) \\
\text { and (3) }[270.14(\mathrm{~b})(5), 264.15(\mathrm{c}) \text {, } \\
264.174]\end{array}$ & & Unit-Specific Portion \\
\hline $\mathrm{F}-2 \mathrm{~d}(2)$ & $\begin{array}{l}\text { Tank System Inspections and Corrective } \\
\text { Actions } \\
\quad 640(6) \text { and (7) }[270.14(\text { b })(5), 264.195]\end{array}$ & & Unit-Specific Portion \\
\hline $\mathrm{F}-2 \mathrm{~d}(2)(\mathrm{a})$ & $\begin{array}{l}\text { a) Tank System Inspections } \\
806(4)(a)(v), 640(6)[264.195]\end{array}$ & & Unit-Specific Portion \\
\hline$F-2 d(2)(b)$ & $\begin{array}{l}\text { b) Tank Systems - Corrective Actions } \\
640(7)[264.196]\end{array}$ & & Unit-Specific Portion \\
\hline $\mathrm{F}-2 \mathrm{~d}(3)$ & $\begin{array}{l}\text { Storage of Ignitable or Reactive Wastes } \\
806(4)(\mathrm{a})(\mathrm{v}), 395(1) \text { (d) [no equivalent } \\
\text { federal requirement] }\end{array}$ & & Unit-Specific Portion \\
\hline $\mathrm{F}-2 \mathrm{~d}(4)$ & $\begin{array}{l}\text { Air Emissions Control and Detection - } \\
\text { Inspections, Monitoring, and Corrective } \\
\text { Actions } \\
\quad(806(4)(\mathrm{a})(\mathrm{v})[270.14(\mathrm{~b})(5), 264.1033 \\
\text { (e) - (k);264.1035;264.1052;264.1053; } \\
264.1058 ; 264.1064 ; 264.1067, \\
\quad 264.1088,264.1091] \\
\end{array}$ & & Unit-Specific Portion \\
\hline $\mathrm{F}-2 \mathrm{~d}(4)(\mathrm{a})$ & $\begin{array}{l}\text { a) Process Vents } \\
\text { 806(4)(a)(v) }[264.1033 ; 264.1034(\mathrm{~b}) \\
\text { and (c);264.1035(b)(3), (b)(4), and (c)] }\end{array}$ & & Unit-Specific Portion \\
\hline
\end{tabular}




\begin{tabular}{|c|c|c|c|}
\hline & & $\begin{array}{l}\text { Technically } \\
\text { Adequate? }\end{array}$ & Location in Application \\
\hline $\mathrm{F}-2 \mathrm{~d}(4)(\mathrm{b})$ & $\begin{array}{l}\text { Equipment Leaks } \\
806(4)(\mathrm{a})(\mathrm{v})[264.1052-264.1064]\end{array}$ & & Unit-Specific Portion \\
\hline $\mathrm{F}-2 \mathrm{~d}(4)(\mathrm{c})$ & $\begin{array}{l}\text { Tanks and Containers } \\
{[270.14(\mathrm{~b})(5), 270.27((\mathrm{a})(6), 264.1088} \\
264.1091] \\
\text { Department of Ecology has not yet } \\
\text { adopted the CC requirements. }\end{array}$ & & Unit-Specific Portion \\
\hline $\begin{array}{ll}\text { F-2d(5) } & W \\
\text { F-2d(6) } & \text { St } \\
\text { F-2d(7) } & \text { In } \\
\text { F-2d(8) } & \text { L } \\
\text { F-2d(9) } & \text { L } \\
\end{array}$ & $\begin{array}{l}\text { Waste Pile Inspection } \\
\text { Surface Impoundment Inspection } \\
\text { ncinerator Inspection } \\
\text {-andfill Inspection } \\
\text { Cand Treatment Facility Inspection }\end{array}$ & & Unit-Specific Portion \\
\hline$F-3$ & $\begin{array}{l}\text { Preparedness and Prevention } \\
\text { Requirements } \\
\text { 806(4)(a)(vi), } 340[270.14(\mathrm{~b})(6) \\
\text { Part 264 Subpart C] } \\
\end{array}$ & & 6.3 \\
\hline F-3a & $\begin{array}{l}\text { Equipment Requirements } \\
340(1) \text { and (2) }[264.32,264.34]\end{array}$ & & $\begin{array}{l}\text { 6.3.I and } \\
\text { Unit-Specific Portion } \\
\end{array}$ \\
\hline$F-3 b$ & $\begin{array}{l}\text { Aisle Space Requirement } \\
340(3)[264.35]\end{array}$ & & 6.3 .2 \\
\hline F-4 & $\begin{array}{l}\text { Preventive Procedures, Structures, and } \\
\text { Equipment } \\
806(4)(\text { a)(viii) }[270.14(\text { b) }(8)]\end{array}$ & & 6.4 \\
\hline F-5 & $\begin{array}{l}\text { Prevention of Reaction of Ignitable, } \\
\text { Reactive, and/or Incompatible Wastes } \\
\text { 806(4)(a)(ix),(b)(v), and (c)(x); } \\
395(1)(\mathrm{a}),(\mathrm{b}) \text { and (c); 630(9)(a) and (b); } \\
\text { 640(9)(10) [270.14(b)(9),264.17(a) and } \\
\text { (b),264.177(a) and (b)] }\end{array}$ & & $\begin{array}{l}6.5 \text { and } \\
\text { Unit-Specific Portion }\end{array}$ \\
\hline F-5a & $\begin{array}{l}\text { Precautions to Prevent Ignition or } \\
\text { Reaction of Ignitable-or Reactive Waste } \\
\text { 806(4)(a)(ix),395(1)(a) and (c) } \\
{[270.14(\text { b)(9),264.17(a)] }}\end{array}$ & & Unit-Specific Portion \\
\hline
\end{tabular}




\begin{tabular}{|c|c|c|c|}
\hline & & $\begin{array}{l}\text { Technically } \\
\text { Adequate? }\end{array}$ & Location in Application \\
\hline$F-5 b$ & $\begin{array}{l}\text { Precautions for Handling Ignitable or } \\
\text { Reactive Waste and Mixing Incompatible } \\
\text { Wastes } \\
806(4)(\text { a)(ix), (b)(v), and (c)(x); } \\
395(1)(\mathrm{b}) \text { and (c); } 630(9)(\mathrm{a}) \text { and (b); } \\
640(9) \text { and (10) [270.14(b)(9), } \\
264.17(\mathrm{~b}), 264.177(\mathrm{a}) \text { and (b)] }\end{array}$ & & Unit-Specific Portion \\
\hline $\mathrm{F}-5 \mathrm{~b}(1)$ & $\begin{array}{l}\text { Ignitable or Reactive Wastes In Tanks } \\
806(4)(\mathrm{c})(\mathrm{x}), 640(9)[270.16(\mathrm{j}) \\
264.198]\end{array}$ & & Unit-Specific Portion \\
\hline $\mathrm{F}-5 \mathrm{~b}(2)$ & $\begin{array}{l}\text { Incompatible Wastes In Containers or Tanks } \\
\text { 806(4)(b)(v) and (4)(c)(x), 630(9) (a) } \\
\text { and (b), 640(10) [270.15(d), 270.16(j) } \\
264.17(\mathrm{~b}) \text { and (c), 264.177(a) and (b), } \\
264.199]\end{array}$ & & Unit-Specific Portion \\
\hline G. & $\begin{array}{l}\text { Contingency Plan } \\
806(4)(\mathrm{a})(\mathrm{vii}), 340,350,360,640(7) \text {, } \\
650(5), 660(6)[270.14(\mathrm{~b})(7), 264.50 \\
\text { through } 264.56]\end{array}$ & & Chapter 7.0 \\
\hline G-I & General Information & & $\begin{array}{l}\text { Attachment } 4 \text { of HF RCRA } \\
\text { Permit (DW Portion) }\end{array}$ \\
\hline G-2 & $\begin{array}{l}\text { Emergency Coordinators } \\
350(3)(d), 360(1)[264.52(d), 264.55]\end{array}$ & & $\begin{array}{l}\text { Attachment } 4 \text { of HF RCRA } \\
\text { Permit (DW Portion) and } \\
\text { Unit-Specific Portion }\end{array}$ \\
\hline G-3 & $\begin{array}{l}\text { Circumstances Prompting } \\
\text { Implementation } \\
350(1) \text { and (2), 360(2) [264.5l, } \\
264.52(a), 264.56(a) \text { and (b)] }\end{array}$ & & $\begin{array}{l}\text { Attachment } 4 \text { of HF RCRA } \\
\text { Permit (DW Portion) and } \\
\text { Unit-Specific Portion }\end{array}$ \\
\hline G-4 & $\begin{array}{l}\text { Emergency Response Procedures } \\
350(3)(\mathrm{a}) \text { and }(\mathrm{b}), 360(2)(\mathrm{a}),(\mathrm{b}), \text { and (c) } \\
{[264.52(\mathrm{a}), 264.56]}\end{array}$ & & $\begin{array}{l}\text { Attachment } 4 \text { of HF RCRA } \\
\text { Permit (DW Portion) and } \\
\text { Unit-specific Portion }\end{array}$ \\
\hline G-4a & $\begin{array}{l}\text { Notification } \\
360(2)(a)[264.56(a)] \\
\text { Note that the facility must also notify } \\
\text { under WAC } 173-303-145 \text {. }\end{array}$ & & $\begin{array}{l}\text { Attachment } 4 \text { of HF RCRA } \\
\text { Permit (DW Portion) and } \\
\text { Unit-Specific Portion }\end{array}$ \\
\hline
\end{tabular}




\begin{tabular}{|c|c|c|c|}
\hline & & $\begin{array}{l}\text { Technically } \\
\text { Adequate? }\end{array}$ & Location in Application \\
\hline$G-4 b$ & $\begin{array}{l}\text { Identification of Dangerous Materials } \\
360(2)(b)[264.56(b)]\end{array}$ & & $\begin{array}{l}\text { Attachment } 4 \text { of HF RCRA } \\
\text { Permit (DW Portion) and } \\
\text { Unit-Specific Portion } \\
\end{array}$ \\
\hline$G-4 c$ & $\begin{array}{l}\text { Hazard Assessment and Report } \\
360(2)(\mathrm{c}),(\mathrm{d}) \text {, and (e) }[264.56(\mathrm{c}) \text { and (d)] }\end{array}$ & & $\begin{array}{l}\text { Attachment } 4 \text { of HF RCRA } \\
\text { Permit (DW Portion) and } \\
\text { Unit-Specific Portion } \\
\end{array}$ \\
\hline $\mathrm{G}-4 \mathrm{~d}$ & $\begin{array}{l}\text { Prevention of Recurrence or Spread of } \\
\text { Fires, Explosions, or Releases } \\
360(2)(f) \text { and }(g), 630(2), 640(7) \\
{[264.56(\mathrm{e}) \text { and (f), 264.171,264.196] }}\end{array}$ & & $\begin{array}{l}\text { Attachment } 4 \text { of HF RCRA } \\
\text { Permit (DW Portion) and } \\
\text { Unit-Specific Portion }\end{array}$ \\
\hline$G-4 f$ & $\begin{array}{l}\text { Post-Emergency Actions } \\
360(2)(\mathrm{h}),(\mathrm{i}),(\mathrm{j}) \text {, and }(\mathrm{k}) ; 640(7) \\
{[264.56(\mathrm{~g}) \text { and }(\mathrm{h})]}\end{array}$ & & $\begin{array}{l}\text { Attachment } 4 \text { of HF RCRA } \\
\text { Permit (DW Portion) and } \\
\text { Unit-Specific Portion }\end{array}$ \\
\hline $\mathrm{G}-5$ & $\begin{array}{l}\text { Emergency Equipment } \\
350(3)(\mathrm{e})[264.52(\mathrm{e})]\end{array}$ & & $\begin{array}{l}\text { Attachment } 4 \text { of HF RCRA } \\
\text { Permit (DW Portion) and } \\
\text { Unit-specific Portion } \\
\end{array}$ \\
\hline G-6 & $\begin{array}{l}\text { Coordination Agreements } \\
350(3)(\mathrm{c}), 340(4)[264.52(\mathrm{c}), 264.37]\end{array}$ & & $\begin{array}{l}\text { Attachment } 4 \text { of HF RCRA } \\
\text { Permit (DW Portion) } \\
\end{array}$ \\
\hline G-7 & $\begin{array}{l}\text { Evacuation Plan } \\
350(3)(\mathrm{f}), 355[264.52(\mathrm{f})]\end{array}$ & & $\begin{array}{l}\text { Attachment } 4 \text { of HF RCRA } \\
\text { Permit (DW Portion) and } \\
\text { Unit-Specific Portion }\end{array}$ \\
\hline G-8 & $\begin{array}{l}\text { Required Reports, Recordkeeping, and } \\
\text { Certifications } \\
360(2)(k), 640(7)(\mathrm{d})(\mathrm{iii}), 640(7)(\mathrm{f}) \\
{[264.56(\mathrm{j})]}\end{array}$ & & $\begin{array}{l}\text { Attachment } 4 \text { of HF RCRA } \\
\text { Permit (DW Portion) and } \\
\text { Unit-Specific Portion }\end{array}$ \\
\hline $\mathrm{G}-8(1)$ & General Requirements & & $\begin{array}{l}\text { Attachment } 4 \text { of HF RCRA } \\
\text { Permit (DW Portion) and } \\
\text { Unit-Specific Portion } \\
\end{array}$ \\
\hline$G-8(2)$ & Requirements for Tank Systems & & $\begin{array}{l}\text { Attachment } 4 \text { of HF RCRA } \\
\text { Permit (DW Portion) and } \\
\text { Unit-Specific Portion }\end{array}$ \\
\hline H. & $\begin{array}{l}\text { Personnel Training } \\
806(4)(\mathrm{a})(\mathrm{xii}), 330[270.14(\mathrm{~b})(12) \text {, } \\
264.16]\end{array}$ & & Chapter 8.0 \\
\hline
\end{tabular}




\begin{tabular}{|c|c|c|c|}
\hline & & $\begin{array}{l}\text { Technically } \\
\text { Adequate? }\end{array}$ & Location in Application \\
\hline $\mathrm{H}-1$ & $\begin{array}{l}\text { Job Title/Job Description } \\
330(2)(a)[264.16(d)(1) \text { and (2)] }\end{array}$ & & Unit-Specific Portion \\
\hline $\mathrm{H}-2$ & $\begin{array}{l}\text { Outline of Training Program } \\
806(4)(\mathrm{a})(\mathrm{xii}), 330(1) \text { and }(2)(\mathrm{b}) \\
{[270.14(\mathrm{~b})(12) ; 264.16(\mathrm{a})(1),(\mathrm{c}) \text {, and }} \\
\text { (d)(3)] }\end{array}$ & & Unit-Specific Portion \\
\hline $\mathrm{H}-3$ & $\begin{array}{l}\text { Implementation of Training Program } \\
330(1)(\mathrm{c}), 330(2)(\mathrm{c}), 330(3)[264.16(\mathrm{~b})]\end{array}$ & & Unit-Specific Portion \\
\hline I. & $\begin{array}{l}\text { Closure and Financial Assurance } \\
806(4)(\mathrm{a})(\mathrm{xiiii}), 610,620[270.14(\mathrm{~b})(15), \\
264.142,264.143,264.151]\end{array}$ & & Chapter 11.0 \\
\hline $\mathrm{I}-1$ & $\begin{array}{l}\text { Closure Plan/Financial Assurance for } \\
\text { Closure } \\
\text { 806(4)(a)(xiii), 610(2) - (6) } \\
{[270.14(\mathrm{~b})(13), 264.111,264.112]}\end{array}$ & & 11.1 \\
\hline I-1a & $\begin{array}{l}\text { Closure Performance Standard } \\
610(2)(\text { b) }[264.111]\end{array}$ & & 11.1 .1 \\
\hline $1-1 b$ & $\begin{array}{l}\text { Closure Activities } \\
610(3)(\text { a)(i) through (vi); } 610(5) ; \\
630(10) ; 640(5)[264.112(b)(1) \\
264.112(b)(4), 264.114,264.178 \\
264.197]\end{array}$ & & 11.1 .2 \\
\hline $\mathrm{I}-1 \mathrm{~b}(1)$ & Maximum Extent of Operation & & 11.1 .2 .1 \\
\hline $\mathrm{I}-\mathrm{lb}(2)$ & Removing Dangerous Wastes & & 11.1.2.2 \\
\hline $\mathrm{I}-\mathrm{lb}(3)$ & $\begin{array}{l}\text { Decontaminating Structures, Equipment, } \\
\text { and Soil }\end{array}$ & & 11.1 .2 .3 \\
\hline $\mathrm{l}-\mathrm{lb}(4)$ & $\begin{array}{l}\text { Sampling and Analysis to Identify Extent } \\
\text { of Decontamination/ Removal and to } \\
\text { Verify Achievement of Closure Standard }\end{array}$ & & 11.1.2.4 \\
\hline $\mathrm{l}-\mathrm{lb}(4)(\mathrm{a})$ & $\begin{array}{l}\text { Sampling to Confirm Decontamination } \\
\text { of Structures and Soils }\end{array}$ & & 11.1 .2 .4 \\
\hline $\mathrm{I}-1 \mathrm{~b}(5)$ & $\begin{array}{l}\text { Other Activities } \\
610(3) \text { (vi) }\end{array}$ & & Unit-Specific Portion \\
\hline
\end{tabular}




\begin{tabular}{|c|c|c|c|}
\hline & & $\begin{array}{l}\text { Technically } \\
\text { Adequate? }\end{array}$ & Location in Application \\
\hline $\mathrm{I}-1 \mathrm{c}$ & $\begin{array}{l}\text { Maximum Waste Inventory } \\
610(3)(\text { a)(iii) }[264.112(b)(3)]\end{array}$ & & 11.1 .3 \\
\hline I-1d & $\begin{array}{l}\text { Closure of Waste Piles, Surface } \\
\text { Impoundments, Incinerators, Land } \\
\text { Treatment, and Miscellaneous Units }\end{array}$ & & 11.1 .4 \\
\hline I-le & Closure of Landfill Units & & 11.1 .5 \\
\hline I-lf & $\begin{array}{l}\text { Schedule for Closure } \\
610(3)(\text { a)(vii) }[264.112(\text { b)(6)] }\end{array}$ & & 11.1 .6 \\
\hline $\mathrm{I}-1 \mathrm{~g}$ & $\begin{array}{l}\text { Extension for Closure Time } \\
610(4)(\mathrm{a}), 610(4)(\mathrm{b})[264.113(\mathrm{a}) \\
264.113(\mathrm{~b})]\end{array}$ & & 11.1.7 \\
\hline $\mathrm{I}-1 \mathrm{~h}$ & $\begin{array}{l}\text { Closure Cost Estimate } \\
806(4)(\mathrm{a})(\mathrm{xv}), 620(3)[270.14(\mathrm{~b})(15) \\
264.142]\end{array}$ & & 11.1 .8 \\
\hline $\mathrm{I}-1 \mathrm{i}$ & $\begin{array}{l}\text { Financial Assurance Mechanism for } \\
\text { Closure } \\
806(4)(\mathrm{a})(\mathrm{xv}), 620(4) \text { and }(10) \\
{[270.14(\mathrm{~b})(15), 264.143,264.151]}\end{array}$ & & 11.1 .9 \\
\hline $\mathrm{I}-2$ & $\begin{array}{l}\text { Notice in Deed of Already Closed } \\
\text { Disposal Units } \\
806(4)(\mathrm{a})(\mathrm{xiv}), 610(10)[270.14(\mathrm{~b})(14), \\
264.120,264.117(\mathrm{c}), 264.119]\end{array}$ & & 11.2 \\
\hline $\mathrm{I}-3$ & Post-Closure Plan & & 11.3 \\
\hline I-4 & $\begin{array}{l}\text { Liability Requirements } \\
806(4)(\mathrm{a})(\text { (xvii), 620(8), 620(10) } \\
{[270.14(\mathrm{~b})(17), 264.147,264.151]}\end{array}$ & & 11.4 \\
\hline$I-4 a$ & $\begin{array}{l}\text { Coverage for Sudden Accidental } \\
\text { Occurrences } \\
620(8)(a)[264.147(a),(f)]\end{array}$ & & 11.4 \\
\hline $\mathrm{I}-4 \mathrm{~b}$ & $\begin{array}{l}\text { Coverage for Nonsudden Accidental } \\
\text { Occurrences }\end{array}$ & & 11.4 \\
\hline$I-4 c$ & $\begin{array}{l}\text { Request for Variance } \\
620(8)(c)[264147(c)]\end{array}$ & & 11.4 \\
\hline
\end{tabular}


DOE/RL-91-28, Rev. 4

\begin{tabular}{|c|c|c|c|}
\hline & & $\begin{array}{l}\text { Technically } \\
\text { Adequate? }\end{array}$ & Location in Application \\
\hline J. & $\begin{array}{l}\text { Other Federal and State Laws } \\
806(4)(\mathrm{a})(\mathrm{xix})[270.14(\mathrm{~b})(20), 270.3]\end{array}$ & & Chapter 13.0 \\
\hline $\mathbf{K}$. & $\begin{array}{l}\text { Part B Certification } \\
806(4)(a), 810(12) \text { and }(13)[270.11]\end{array}$ & & Chapter 14.0 \\
\hline
\end{tabular}


DOE/RL-91-28, Rev. 4

05/98

\section{CONTENTS}

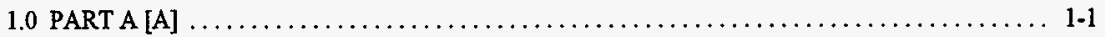

\section{TABLE}

7

9

10 1-1. Hanford Facility Treatment, Storage, and/or Disposal Units

T1-1 
DOE/RL-91-28, Rev. 4

$05 / 98$

This page intentionally left blank. 
This chapter addresses Section A of the Washington State Department of Ecology's (Ecology) Dangerous Waste Permit Application Requirements (permit application guidance) (Ecology 1987 and 1996). This permit application guidance calls for a discussion of the Part A forms for the Hanford Facility.

The Hanford Facility is a single Resource Conservation and Recovery Act (RCRA) of 1976 facility, and as such has been issued a single identification number by the U.S. Environmental Protection Agency (EPA) and Ecology (EPA/State Identification Number WA7890008967). The Hanford Facility consists of over 60 treatment, storage, and/or disposal (TSD) units (Table 1-1). These TSD units include, but are not limited to, tank systems, surface impoundments, container storage areas, containment buildings, landfills, and miscellaneous units.

The current Hanford Facility Dangerous Waste Part A Permit Application (HF Part A) (DOE/RL-88-21) consists of three "Dangerous Waste Permit General Information, Form 1s" (submitted at the facility level for each co-operator); a single "Notice of Dangerous Waste Activities, Form 2" (submitted at the facility level); and over 60 "Dangerous Waste Permit Application, Form 3s" (submitted at the unit level). The HF Part A consolidates into a single controlled document the current revisions of all Part A permit application forms. Thus, the contents of this document have not been reproduced for inclusion in the Part A chapter of the Hanford Facility Dangerous Waste Permit Application, General Information Portion.

The HF Part A is designed to facilitate the insertion of new or revised material and is updated quarterly. All revisions to Part A, Form 3 s for interim status TSD units are carried out in accordance with the requirements of the Dangerous Waste Regulations, Washington Administrative Code (WAC) 173-303-805(7). All revisions to Part A, Form 3s for final status TSD units are carried out in accordance with Condition I.C.3. of the Hanford Facility RCRA Permit (HF RCRA Permit), Dangerous Waste Portion (DW Portion). These revisions include those for TSD units that have been clean closed (refer to Chapter 11.0, Section 11.1.1.1 and 11.5). The Part A, Form 3s for clean-closed TSD units are revised to include the word "CLOSED" across the front of the form and the date the closure certification was accepted by Ecology. The Part A, Form 3s for interim status TSD units that have been procedurally closed in accordance with Section 6.3.3 of the Hanford Federal Facility Agreement and Consent Order (Tri-Party Agreement) also are revised to include the word "CLOSED" across the front of the form and the date the procedural closure certification was accepted by Ecology. 
This page intentionally left blank. 
Table 1-1. Hanford Facility Treatment, Storage, and/or Disposal Units. (sheet 1 of 6 )

\begin{tabular}{|c|c|c|c|c|c|c|}
\hline Unit name and type ${ }^{1}$ & $\begin{array}{c}\text { Document }{ }^{2} \\
\text { type }\end{array}$ & Classification $^{3}$ & $\begin{array}{l}\text { Waste } \\
\text { type }^{4}\end{array}$ & Location $^{5}$ & $\mathrm{Co}-\mathrm{Op}{ }^{6}$ & Project ${ }^{7}$ \\
\hline \multicolumn{7}{|c|}{ 'Operating' Treatment, Storage, and/or Disposal Units } \\
\hline Double-Shell Tank System (TS) & B & 3,4 & $\mathrm{M}$ & $200 \mathrm{EW}$ & FDH & TWRS \\
\hline 204-AR Waste Unloading Station $(\mathrm{T})$ & $\mathrm{B}$ & 4 & $\mathrm{M}$ & $200 \mathrm{E}$ & $\mathrm{FDH}$ & TWRS \\
\hline 242-A Evvaporator (TS) & B & 3,4 & M & $200 \mathrm{E}$ & FDH & WM \\
\hline 222-S Laboratory Complex (TS) & B & $1,2,3,4$ & $\mathrm{M}$ & $200 \mathrm{~W}$ & FDH & WM \\
\hline 200 Area Effluent Treatment Facility (TS) & B & $1,2,3,4$ & $\mathrm{M}$ & $200 \mathrm{E}$ & FDH & WM \\
\hline Liquid Effluent Retention Facility (TS) & B & 6,7 & $\mathrm{M}$ & $200 \mathrm{E}$ & FDH & WM \\
\hline Central Waste Complex (TS) & B & 1,2 & $\mathrm{M}$ & $200 \mathrm{~W}$ & FDH & WM \\
\hline Waste Receiving and Processing(TS) & B & 1,2 & $\mathrm{M}$ & $200 \mathrm{~W}$ & FDH & WM \\
\hline Low-Level Burial Grounds (SD) & B & 1,11 & $\mathrm{M}$ & $200 \mathrm{EW}$ & FDH & $\mathrm{WM}$ \\
\hline T Plant Complex (TS) & B & $1,2,3,4,10,13$ & $\mathrm{M}$ & $200 \mathrm{~W}$ & FDH & WM \\
\hline 616 Nonradioactive Dangerous Waste Storage Facility (S) & $\mathrm{B}$ & 1 & H & 600 & FDH & WM \\
\hline PUREX Storage Tunnels (S) & B & 12 & $\mathrm{M}$ & $200 \mathrm{E}$ & $\mathrm{FDH}$ & FT \\
\hline 325 Hazardous Waste Treatment Units (TS) & $\mathrm{B}$ & $1,2,3,4$ & $\mathrm{M}$ & 300 & PNNL & ST \\
\hline 305-B Storage Unit (S) & B & 1 & $\mathrm{M}$ & 300 & PNNL & ST \\
\hline Waste Encapsulation and Storage Facility (S) & $\mathrm{U}$ & 12 & M & $200 \mathrm{E}$ & FDH & TWRS \\
\hline \multicolumn{7}{|c|}{ Treatment, Storage, and/or Disposal Units 'Undergoing Closure' } \\
\hline 224-T Transuranic Waste Storage and Assay Facility (S) & $\mathrm{C}$ & 1 & $\mathrm{M}$ & $200 \mathrm{~W}$ & FDH & $\mathrm{WM}$ \\
\hline 207-A South Retention Basin (S) & $\mathrm{U}$ & 6 & $\mathrm{M}$ & $200 \mathrm{E}$ & FDH & TWRS \\
\hline 216-B-3 Expansion Ponds (TD) & $\mathrm{C}$ & $7,8,15$ & $\mathrm{M}$ & $200 \mathrm{E}$ & Other & TWRS \\
\hline
\end{tabular}




\begin{tabular}{|c|c|c|c|c|c|c|}
\hline Unit name and type ${ }^{1}$ & $\begin{array}{c}\text { Document }^{2} \\
\text { type }\end{array}$ & Classification $^{3}$ & $\begin{array}{l}\text { Waste } \\
\text { type }\end{array}$ & Location $^{5}$ & $\mathrm{Co}-\mathrm{Op}^{6}$ & Project? \\
\hline 216-B-63 Trench (TD) & $\mathrm{C} / \mathrm{PC}$ & 7,8 & $\mathrm{M}$ & $200 \mathrm{E}$ & $\mathrm{FDH}$ & TWRS \\
\hline 200 West Area Ash Pit Demolition Site (T). & $\mathrm{C}$ & 13,15 & $\mathrm{H}$ & $200 \mathrm{~W}$ & Other & WM \\
\hline 218-E-8 Borrow Pit Demolition Site (T) & $\mathrm{C}$ & 13,15 & $\mathbf{H}$ & $200 \mathrm{E}$ & Other & WM \\
\hline Hanford Patrol Academy Demolition Sites (T) & $\mathrm{C}$ & 13,15 & $\mathbf{H}$ & 600 & Other & WM \\
\hline 2727-S Storage Facility (S) & C & 1,15 & $\mathbf{H}$ & $200 \mathrm{~W}$ & Other & WM \\
\hline 4843 Alkali Metal Storage Facility (S) & C & 1,15 & M & 400 & FDH & FT \\
\hline 105-DR Large Sodium Fire Facility (TS) & $\mathrm{PC}$ & $1,13,17$ & $\mathbf{H}$ & 100 & FDH & FT \\
\hline 3718-F Alkali Metal Treatment and Storage Area (TS) & $\mathrm{C}$ & $1,4,13$ & M & 300 & FDH & FT \\
\hline 304 Concretion Facility (TS) & $\mathrm{C}$ & $1,2,15$ & M & 300 & Other & FT \\
\hline 300 Area Solvent Evaporator (TS) & $\mathrm{C}$ & $1,4,15$ & $\mathrm{M}$ & 300 & Other & FT \\
\hline 300 Area Waste Acid Treatment System (TS) & $\mathrm{C}$ & $3,4,13$ & M & 300 & $\mathrm{FDH}$ & FT \\
\hline 303-M Oxide Facility (T) & $\mathrm{C}$ & 9 & $\mathrm{M}$ & 300 & FDH & FT \\
\hline 303-K Storage Unit (S) & $\mathrm{C}$ & 1 & $\mathrm{M}$ & 300 & FDH & FT \\
\hline 1706-KE Waste Treatment System (TS) & $\mathrm{C}$ & 3,13 & M & 100 & FDH & WM \\
\hline 2101-M Pond (D) & $\mathrm{C}$ & 8,15 & $\mathrm{H}$ & $200 \mathrm{E}$ & Other & BWIP \\
\hline Hexone Storage and Treatment Facility (TS) & $\mathrm{C}$ & $1,3,4$ & $\mathrm{M}$ & $200 \mathrm{~W}$ & $\mathrm{BHI}$ & ER \\
\hline 241-CX Tank System (S) & $\mathrm{U}$ & 3 & $\mathrm{M}$ & $200 \mathrm{E}$ & BHI & ER \\
\hline 183-H Solar Evaporation Basins (TS) & $\mathrm{C} / \mathrm{PP}$ & 3,4 & $\mathrm{M}$ & 100 & BHI & ER \\
\hline 1324-N Surface Impoundment $(T)$ & $\mathrm{C} / \mathrm{PC}$ & 7 & $\mathrm{H}$ & 100 & BHI & ER \\
\hline 1301-N Liquid Waste Disposal Facility (D) & $\mathrm{C} / \mathrm{PC}$ & 11 & M & 100 & $\mathrm{BHI}$ & ER \\
\hline 1325-N Liquid Waste Disposal Facility (D) & $\mathrm{C} / \mathrm{PC}$ & 11 & $\mathrm{M}$ & 100 & BHI & $\mathrm{ER}$ \\
\hline
\end{tabular}

Table 1-1. Hanford Facility Treatment, Storage, and/or Disposal Units. (sheet 2 of 6 ) 
Table 1-1. Hanford Facility Treatment, Storage, and/or Disposal Units. (sheet 3 of 6)

\begin{tabular}{|c|c|c|c|c|c|c|}
\hline Unit name and type ${ }^{1}$ & $\begin{array}{l}\text { Document }^{2} \\
\text { type }\end{array}$ & Classification ${ }^{3}$ & $\begin{array}{c}\text { Waste } \\
\text { type }\end{array}$ & Location ${ }^{5}$ & $\mathrm{Co}-\mathrm{Op}^{6}$ & Project $^{7}$ \\
\hline 1324-NA Percolation Pond (TD) & $\mathrm{C} / \mathrm{PC}$ & 8,13 & $\mathrm{H}$ & 100 & $\mathrm{BHI}$ & ER \\
\hline 100-D Ponds (TD) & $\mathrm{C} / \mathrm{PC}$ & 8,13 & $\mathrm{H}$ & 100 & $\mathrm{BHI}$ & ER \\
\hline 216-S-10 Pond and Ditch (D) & $\mathrm{C} / \mathrm{PC}$ & 8 & $\mathrm{M}$ & $200 \mathrm{~W}$ & $\mathrm{BHI}$ & ER \\
\hline 216-A-29 Ditch (TD) & $\mathrm{C} / \mathrm{PC}$ & 8,13 & M & $200 \mathrm{E}$ & $\mathrm{BHI}$ & ER \\
\hline 216-B-3 Main Pond (TD) & $\mathrm{C} / \mathrm{PC}$ & 7,8 & M & $200 \mathrm{E}$ & $\mathrm{BHI}$ & ER \\
\hline 216-A-10 Crib (D) & $\mathrm{C} / \mathrm{PC}$ & 11 & M & $200 \mathrm{E}$ & $\mathrm{BHI}$ & ER \\
\hline 216-U-12 Crib (D) & $\mathrm{C} / \mathrm{PC}$ & 11 & $\mathrm{M}$ & $200 \mathrm{~W}$ & $\mathrm{BHI}$ & ER \\
\hline 216-A-36B Crib (D) & $\mathrm{C} / \mathrm{PC}$ & 11 & M & $200 \mathrm{E}$ & $\mathrm{BHI}$ & ER \\
\hline 216-A-37-1 Crib (D) & $\mathrm{C} / \mathrm{PC}$ & 11 & $\mathrm{M}$ & $200 \mathrm{E}$ & $\mathrm{BHI}$ & ER \\
\hline 300 Area Process Trenches (D) & $\mathrm{C} / \mathrm{PP}$ & 8 & $\mathbf{M}$ & 300 & $\mathrm{BHI}$ & ER \\
\hline Nonradioactive Dangerous Waste Landfill (D) & $\mathrm{C} / \mathrm{PC}$ & 11 & $\mathrm{H}$ & 600 & $\mathrm{BHI}$ & ER \\
\hline $\begin{array}{l}\text { Simulated High-Level Waste Slurry Treatment/Storage } \\
\text { (TS) }\end{array}$ & $\mathrm{C}$ & $1,2,15$ & M & 300 & PNNL & ST \\
\hline \multicolumn{7}{|c|}{$\begin{array}{l}\text { Treatment, Storage, and/or Disposal Units which are, or are Anticipated to be, } \\
\text { 'Dispositioned through Other Options' }\end{array}$} \\
\hline PUREX Plant (TS) & $\mathrm{O}^{\mathrm{a}}$ & $3,4,10$ & $\mathrm{M}$ & $200 \mathrm{E}$ & FDH & FT \\
\hline 241-Z Treatment and Storage Tanks (TS) & $\mathrm{O}^{\mathrm{a}}$ & 3,4 & $\mathrm{M}$ & $200 \mathrm{~W}$ & FDH & FT \\
\hline B Plant Complex (TS) & $\mathrm{O}^{\mathrm{a}}$ & $1,3,4,10$ & $\mathrm{M}$ & $200 \mathrm{E}$ & FDH & FT \\
\hline 221-T Containment Systems Test Facility (T) & $\mathrm{O}^{\mathrm{b}}$ & 13 & $\mathrm{H}$ & $200 \mathrm{~W}$ & $\mathrm{FDH}$ & FT \\
\hline $\begin{array}{l}\text { 2727-WA Sodium Reactor Experiment Sodium Storage } \\
\text { Building (S) }\end{array}$ & $\mathrm{O}^{\mathrm{b}}$ & 1 & M & $200 \mathrm{~W}$ & FDH & WM \\
\hline 437 Maintenance and Storage Facility (T) & $\mathrm{O}^{\mathrm{b}}$ & 4 & $\mathrm{M}$ & 400 & $\mathrm{FDH}$ & FT \\
\hline
\end{tabular}


Table 1-1. Hanford Facility Treatment, Storage, and/or Disposal Units. (sheet 4 of 6 )

\begin{tabular}{|c|c|c|c|c|c|c|}
\hline Unit name and type ${ }^{1}$ & $\begin{array}{c}\text { Document } \\
\text { type }\end{array}$ & Classification $^{3}$ & $\begin{array}{l}\text { Waste } \\
\text { type }\end{array}$ & Location $^{5}$ & $\mathrm{Co}-\mathrm{Op}^{6}$ & Project $^{?}$ \\
\hline 324 Pilot Plant $(\mathrm{T})$ & $\mathrm{O}^{\mathrm{b}}$ & 4,16 & M & 300 & PNNL & ST \\
\hline Biological Treatment Test Facilities (T) & $\mathrm{O}^{\mathrm{b}}$ & 13,16 & $\mathrm{M}$ & 300 & PNNL & ST \\
\hline Physical and Chemical Treatment Test Facilities (TS) & $\mathrm{O}^{\mathrm{b}}$ & $1,13,16$ & $\mathrm{M}$ & 300 & PNNL & ST \\
\hline Thermal Treatment Test Facilities ( $\mathrm{T}$ ) & $\mathrm{O}^{\mathrm{b}}$ & 13,16 & $\mathbf{M}$ & 300 & PNNL & ST \\
\hline 332 Storage Facility (S) & $\mathrm{O}^{\mathrm{b}}$ & 1,16 & $\mathrm{M}$ & 300 & PNNL & $\mathrm{ST}$ \\
\hline $\begin{array}{l}\text { Sodium Storage Facility and } \\
\text { Sodium Reaction Facility (TS) }\end{array}$ & $\mathrm{O}^{\mathrm{c}}$ & 3,4 & M & 400 & FDH & FT \\
\hline 600 Area Purgewater Storage and Treatment Facility (TS) & $\mathrm{O}^{\alpha}$ & 12,13 & $\mathrm{M}$ & 600 & FDH & WM \\
\hline Single-Shell Tank System (TS) & $\mathrm{O}^{\circ}$ & $3,4,5$ & M & $200 \mathrm{EW}$ & $\mathrm{FDH}$ & TWRS \\
\hline Grout Treatment Facility (TSD) & $\mathrm{O}^{\mathrm{f}}$ & $3,4,7,11$ & M & $200 \mathrm{E}$ & FDH & TWRS \\
\hline Hanford Waste Vitrification Plant (TS) & $\mathrm{O}^{\mathrm{s}}$ & $1,3,4,12,13$ & M & $200 \mathrm{E}$ & FDH & TWRS \\
\hline
\end{tabular}

KEY:

${ }^{1}$ UNIT NAME AND TYPE Name of Hanford Facility TSD unit and type (in parentheses). The letters designate the unit type as follows:

$$
\begin{array}{ll}
\text { T -- } & \text { Treatment } \\
\text { S -- } & \text { Storage } \\
\text { D -- } & \text { Disposal. }
\end{array}
$$


KEY (cont):

${ }^{2}$ DOCUMENT TYPE

Type of documentation submitted, and/or anticipated to be submitted, to support disposition:

B -- Part B

C -- Closure plan

PC -- Partial closure

PP -- Postclosure plan

W -- Closure work plan

U -. Undetermined

O -- Other options:

a TSD unit being closed, or anticipated to be closed, under Section 8.0 of the Hanford Federal Facility Agreement and Consent Order (Tri-Party Agreement)

b Procedural closure in accordance with Section 6.3.3 of the Tri-Party Agreement or in response to withdrawal requests submitted in fulfillment of Tri-Party Agreement Milestone M-20-45

- To be designated as a TSD unit if the Fast Flux Test Facility sodium is determined to have no beneficial use

Interim status TSD unit to be closed in accordance with the Purgewater Management Plan [Attachment 5 of the HF RCRA Permit (DW Portion)]

- TSD unit subject to the closure work plan/closure plan process in accordance with Tri-Party Agreement Milestone M-45-06

f Interim status TSD unit in a standby mode

$\mathrm{g}$ Interim status TSD unit is to be superseded by a high-level waste immobilization facility.

1 -- Container - Storage

2 -- Container - Treatment

3 -- Tank - Storage

4 -- Tank - Treatment

5 -- Waste pile

6 -- Surface impoundment - Storage

7 -- Surface impoundment - Treatment

8 -- Surface impoundment - Disposal

9 -- Incinerator 


\section{KEY (cont):}

CLASSIFICATION (cont) 10 -- Containment Building

11 -- Landfill

12 -. Miscellaneous - Storage

13 -- Miscellaneous - Treatment

14 -- Land treatment

15 -- Certified clean closure; regulatory acceptance letter received.

16 -. Certified procedural closure; regulatory acceptance letter received.

17 -. . Certified partial clean closure; regulatory acceptance letter received.

\section{${ }^{4}$ WASTE TYPE}

M -- TSD unit manages, managed, or is/was anticipated to manage mixed waste and dangerous waste.

$\mathrm{H}$-- TSD unit manages, managed, or is/was anticipated to manage dangerous waste.

\section{${ }^{5}$ LOCATION}

The area of the Hanford Facility in which the TSD unit is located:

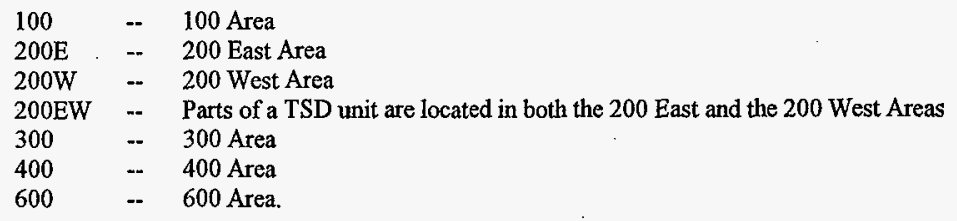

${ }^{6} \mathrm{CO}-\mathrm{OP}$

Co-operator with the U.S. Department of Energy, Richland Operations Office as the owner/operator:

BHI -- Bechtel Hanford, Inc.

PNNL -- Pacific Northwest National Laboratory

FDH -- Fluor Daniel Hanford, Inc.

Other -- Closed by a previous co-operator.

${ }^{7}$ PROJECT Hanford Projects are as follows:
TWRS -- Tank Waste Remediation System
WM -- Waste Management
FT -- Facility Transition
ER - Environmental Restoration
ST - - Science and Technology.




\section{CONTENTS}

2.0 FACILITY DESCRIPTION AND GENERAL PROVISIONS [B AND E] $\ldots \ldots \ldots \ldots \ldots \ldots .2-1$

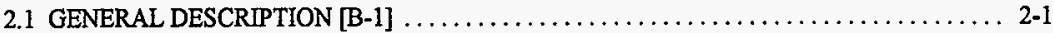

2.1.1 Facility Description [B-1a] $\ldots \ldots \ldots \ldots \ldots \ldots \ldots \ldots \ldots \ldots \ldots \ldots \ldots \ldots \ldots \ldots \ldots \ldots \ldots \ldots, 2-3$

2.1.1.1 Hanford Site $\ldots \ldots \ldots \ldots \ldots \ldots \ldots \ldots \ldots \ldots \ldots \ldots \ldots \ldots \ldots \ldots \ldots \ldots, 2-3$

2.1.1.2 Hanford Facility $\ldots \ldots \ldots \ldots \ldots \ldots \ldots \ldots \ldots \ldots \ldots \ldots \ldots \ldots \ldots, 2,4$

2.1.1.3 Hanford Facility Permitting $\ldots \ldots \ldots \ldots \ldots \ldots \ldots \ldots \ldots \ldots \ldots \ldots \ldots \ldots \ldots \ldots \ldots, 2-5$

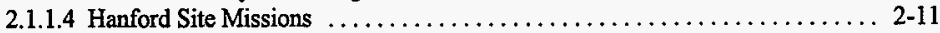

2.1.1.5 Description of Dangerous Waste Management Operations and

Processes ................................... 2-13

2.1.1.6 Other Processes Regulated Under the Dangerous Waste Regulations ....... 2-13

2.1.1.7 Other Environmental Permits . . . . . . . . . . . . . . . . . . . . . . . . . . $2-13$

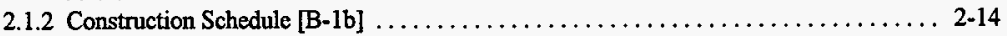

2.2 TOPOGRAPHIC MAP $[\mathrm{B}-2] \ldots \ldots \ldots \ldots \ldots \ldots \ldots \ldots \ldots \ldots \ldots \ldots \ldots \ldots \ldots \ldots \ldots \ldots \ldots \ldots \ldots \ldots \ldots, 2-14$

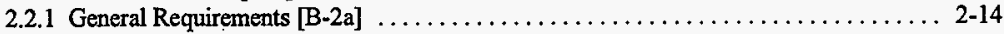

2.2.1.1 Hanford Facility $\ldots \ldots \ldots \ldots \ldots \ldots \ldots \ldots \ldots \ldots \ldots \ldots \ldots \ldots \ldots \ldots \ldots \ldots \ldots, 2-15$

2.2.1.2 Treatment, Storage, and Disposal Units ...................... 2-15

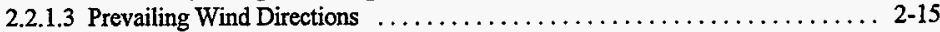

2.2.1.4 Floodplain Area $\ldots \ldots \ldots \ldots \ldots \ldots \ldots \ldots \ldots \ldots \ldots \ldots \ldots \ldots \ldots \ldots \ldots \ldots \ldots \ldots, 2-16$

2.2.2 Additional Requirements for Land Disposal Facilities [B-2b] $\ldots \ldots \ldots \ldots \ldots \ldots \ldots$. $2-16$

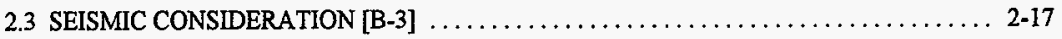

2.4 TRAFFIC INFORMATION $[\mathrm{B}-4] \ldots \ldots \ldots \ldots \ldots \ldots \ldots \ldots \ldots \ldots \ldots \ldots \ldots \ldots \ldots \ldots \ldots \ldots \ldots \ldots \ldots \ldots, 2-17$

2.4.1 Hanford Site Roadways $\ldots \ldots \ldots \ldots \ldots \ldots \ldots \ldots \ldots \ldots \ldots \ldots \ldots \ldots \ldots \ldots \ldots \ldots \ldots \ldots \ldots, 2-17$

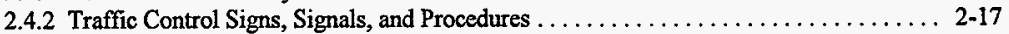

2.4.3 Hanford Site Railroad System $\ldots \ldots \ldots \ldots \ldots \ldots \ldots \ldots \ldots \ldots \ldots \ldots \ldots \ldots \ldots \ldots \ldots \ldots \ldots, 2-18$

2.5 WASTE MANAGEMENT UNITS $\ldots \ldots \ldots \ldots \ldots \ldots \ldots \ldots \ldots \ldots \ldots \ldots \ldots \ldots \ldots \ldots \ldots \ldots \ldots, 2-18$

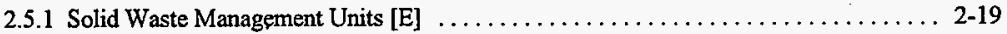

2.5.1.1 Treatment, Storage, and/or Disposal Units 'Undergoing Closure' . . . . . . . . . 2 2-19

2.5.1.2 Past-Practice Units . ...................................... 2-25

2.5.1.3 Procedural Closure $\ldots \ldots \ldots \ldots \ldots \ldots \ldots \ldots \ldots \ldots \ldots \ldots \ldots \ldots \ldots \ldots \ldots \ldots \ldots \ldots, 2-26$

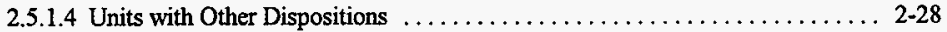

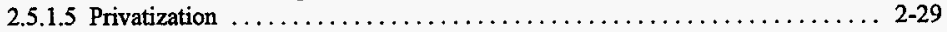

2.5.1.6 Other Solid Waste Management Units ........................ 2-30

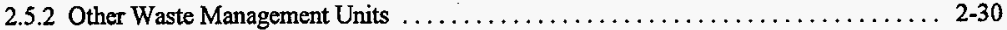

2.5.2.1 Facilities Subject to Decommissioning $\ldots \ldots \ldots \ldots \ldots \ldots \ldots \ldots \ldots \ldots \ldots \ldots$ 
2A LOCATION MAPS

APP 2A-i

2B GLOSSARY

APP 2B-i

2C HANFORD FACILITY LEGAL DESCRIPTION

APP 2C-i

2D SOLID WASTE MANAGEMENT UNITS

APP 2D-i

\section{FIGURES}

2-1. Hanford Site

F2-1

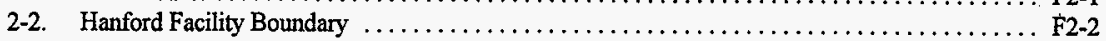

2-3. Permitting Process Flowchart

F2-3

2-4. Closure Process Flowchart $\ldots \ldots \ldots \ldots \ldots \ldots \ldots \ldots \ldots \ldots \ldots \ldots \ldots \ldots \ldots \ldots \ldots \ldots \ldots \ldots \ldots \ldots$, F2 -4

2-5. Permit Modification Flowchart $\ldots \ldots \ldots \ldots \ldots \ldots \ldots \ldots \ldots \ldots \ldots \ldots \ldots \ldots \ldots \ldots \ldots \ldots \ldots \ldots$, F2 -5

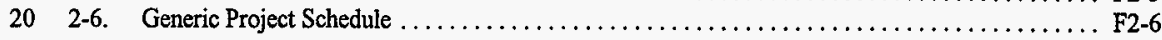

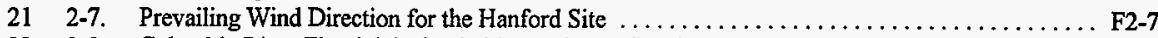

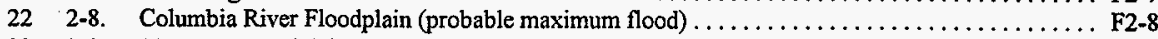

2-9. 100-Year Floodplain of the Columbia River and Yakima River

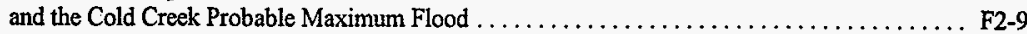

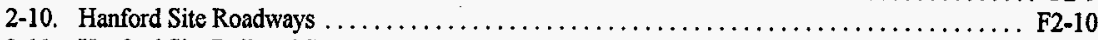

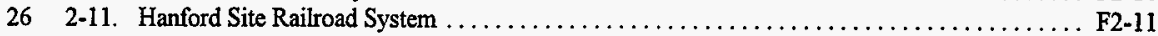

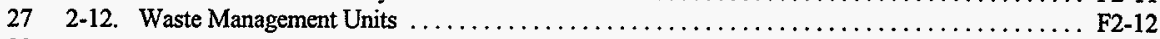




\subsection{FACILITY DESCRIPTION AND GENERAL PROVISIONS [B AND E]}

3

4

This chapter describes the Hanford Site and Hanford Facility and addresses general provisions and information needs identified in Sections B and E of Ecology's permit application guidance (Ecology 1987 and 1996). Topics discussed include the following:

- General description

- Topography

- Location information

- Seismic consideration

- Traffic information

- Waste management units.

Provisions included in Standard Conditions of the HF RCRA Permit (Part I of the DW Portion) also are addressed.

The information contained in Chapter 2.0 need not be duplicated in the Unit-Specific Portion of the Hanford Facility Dangerous Waste Permit Application or in preclosure work plan, closure work plan, closure plan, closure/postclosure plan, or postclosure permit application documentation, but will be cross-referenced as appropriate (including the Glossary contained in Appendix 2B of the General Information Portion).

\subsection{GENERAL DESCRIPTION [B-1]}

The Hanford Facility is owned by the U.S. Government and operated by the U.S. Department of Energy, Richland Operations Office (DOE-RL). Dangerous waste and mixed waste (containing both dangerous and radioactive components) are generated and managed on the Hanford Facility. Waste components are regulated in accordance with the RCRA, the Hazardous and Solid Waste Amendments (HSWA) of 1984, and/or the State of Washington Hazardous Waste Management Act of 1976 (as administered through Ecology's Dangerous Waste Regulations, WAC 173-303); or the Atomic Energy Act of.1954.

The permitting framework for the Hanford Facility was established by the original 1989 Tri-Party Agreement. The original document addressed the Hanford Facility as a single RCRA facility (EPA/State Identification Number WA7890008967) consisting of over 60 TSD units. Approximately 25 percent of these units are, or are anticipated to be, 'operating'; approximately 50 percent are 'undergoing closure'; and approximately 25 percent are, or are anticipated to be, 'dispositioned through other options' under the Tri-Party Agreement (refer to Chapter 1.0, Table 1-1).

The original Tri-Party Agreement also established a stepwise permitting process that provided for the issuance of an initial RCRA permit for less than the entire Hanford Facility. Any TSD units not included in the initial permit were to be incorporated through a permit modification. The TSD units not yet incorporated into the RCRA permit were to continue to operate under interim status. Subsequent amendments of the Tri-Party Agreement have retained the RCRA permitting approach established by the original 1989 document. 
The initial HF RCRA Permit became effective in September 1994, and is comprised of two portions, a DW Portion, issued by Ecology, and a HSWA Portion, issued by the EPA, Region 10. The DW Portion is issued to four Permittees: DOE-RL, as the owner/operator, and to three of its contractors, as co-operators. The HSWA Portion is issued to DOE-RL, as the owner/operator.

For purposes of the Hanford Facility Dangerous Waste Permit Application, the U.S. Department of Energy's contractors are identified as 'co-operators' and sign in that capacity (refer to Condition I.A.2. of the HF RCRA Permit [DW Portion]). Any identification of these contractors as an 'operator' elsewhere in the application is not meant to conflict with the contractors' designation as co-operators but rather is based on the contractors' contractual status with the U.S. Department of Energy, Richland Operations Office.

The permit modification process will be used at least annually to incorporate additional TSD units as permitting documentation for these units is finalized. The units to be included in annual modifications are specified in a schedule contained as Attachment 27 of the HF RCRA Permit (DW Portion). Hanford Facility TSD units will remain in interim status until incorporated into the HF RCRA Permit. Reference to the HF RCRA Permit in the remainder of this document refers to the most recent revision, unless otherwise specified.

The Hanford Facility Dangerous Waste Permit Application is considered to be a single application organized into a General Information Portion (this document, DOE/RL-91-28) and a Unit-Specific Portion. The scope of the Unit-Specific Portion is limited to individual, 'operating' TSD units for which Part B permit application documentation has been, or is anticipated to be, submitted (refer to Chapter 1.0, Table 1-1). Documentation for TSD units 'undergoing closure', or for units that are, or are anticipated to be, 'dispositioned through other options', will continue to be submitted by the Permittees in accordance with the provisions of the Tri-Party Agreement. However, the scope of the General Information Portion includes information that could be used to discuss 'operating' units, units 'undergoing closure', or units being 'dispositioned through other options'. Alternatives for addressing Hanford Facility TSD units are identified as follows:

- 'Operating' TSD unit (submittal of Part B permit application documentation)

- TSD unit 'undergoing closure'

- Clean closure (submittal of closure plan documentation)

- Modified closure (submittal of closure/postclosure plan and postclosure permit application documentation)

- Closure as a land disposal unit (submittal of closure/postclosure plan and postclosure permit application documentation)

- Closure in conjunction with an operable unit (in accordance with Section 6.1 of the Tri-Party Agreement).

- TSD unit 'dispositioned through other options'

- Procedural closure (in accordance with Section 6.3.3 of the Tri-Party Agreement or in response to withdrawal requests submitted in fulfillment of Tri-Party Agreement Milestone M-20-45) 
- Facility decommissioning process (in accordance with Section 8.0 of the Tri-Party Agreement)

- TSD unit operating under interim status in accordance with a specific agreement between DOE-RL and the regulators [e.g., Purgewater Management Plan (Attachment 5 of the HF RCRA Permit)]

- TSD unit subject to the closure work plan/closure plan process in accordance with Tri-Party Agreement Milestone M-45-06 [e.g., Single-Shell Tank Closure Work Plan (DOE/RL-89-16)].

Further discussion of these alternatives is included in Sections 2.1.1.3 and 2.5.

The intent of the General Information Portion is: (1) to provide an overview of the Hanford Facility; and (2) to assist in streamlining efforts associated with TSD unit-specific Part B permit application, preclosure work plan, closure work plan, closure plan, closure/postclosure plan, or postclosure permit application documentation development and the HF RCRA Permit modification process. Wherever appropriate, the Unit-Specific Portion of the application, as well as preclosure work plan, closure work plan, closure plan, closure/postclosure plan, or postclosure permit application documentation, will make cross-reference to the General Information Portion, rather than duplicating text. Thus, HF RCRA Permit modifications involving general information will require updating only the General Information Portion instead of each unit-specific document.

\subsubsection{Facility Description [B-1a]}

This section includes a general description and/or discussion of the following:

- Hanford Site

- Hanford Facility

- Hanford Facility permitting

- Hanford Site Missions

- Description of dangerous waste management operations and processes

- Other processes regulated under WAC 173-303

- Other environmental permits.

2.1.1.1 Hanford Site. The Hanford Site covers approximately 1,450 square kilometers of semiarid land that is owned by the U.S. Government and managed by the DOE-RL (Figure 2-1). The city of Richland adjoins the southeastern most portion of the Hanford Site boundary and is the nearest population center.

In early 1943, the U.S. Army Corps of Engineers selected the Hanford Site as the location for plutonium production for national defense. For over 20 years, activities were primarily dedicated to the continuation of plutonium production and managing the waste generated. In later years, activities became increasingly diverse, involving research and development for advanced reactors and renewable energy technologies. The end of the Cold War brought the shutdown of most of the Hanford Site's plutonium production and management facilities. Current missions are to safely clean up and manage the legacy waste on the Hanford Site, and to develop and deploy science and technology (DOE/RL-96-92).

The Hanford Site is divided into numerically designated areas (Drawing H-6-958 in Appendix 2A). These areas served as the location for reactor, chemical separation, and related activities for the production 
1 and purification of special nuclear materials (Appendix 2B) and other nuclear activities. The reactors are 2 located along the Columbia River in the 100 Areas. The reactor fuel reprocessing units are in the 200 Areas, 3 which are on a plateau approximately 11 kilometers from the Columbia River. The 300 Area, located development laboratories, and the Environmental and Molecular Sciences Laboratory. The 400 Area, 8 kilometers northwest of the 300 Area, contains the Fast Flux Test Facility designed for testing liquid metal reactor systems. The 600 Area covers all locations not specifically given an area designation. Adjacent to and north of Richland, the 1100 Area contains offices associated with administration, maintenance, transportation, and materials procurement and distribution. Offices also are located in the $700 \mathrm{Area}$, which is in downtown Richland.

Where general information for the Hanford Site is discussed in this permit application portion, such information also applies to the Hanford Facility, unless otherwise designated.

2.1.1.2 Hanford Facility. The Hanford Facility currently contains over 60 TSD units (refer to Chapter 1.0, Table 1-1) described in the HF Part A. The boundary of the Hanford Facility, as defined in Attachment 2 of the HF RCRA Permit (DW Portion), is shown in Figure 2-1. As noted in Figure 2-1, this facility definition only excludes land owned by Washington State. However, a Permit Applicability Matrix contained as Attachment 3 of the HF RCRA Permit (DW Portion) does indicate that Permit conditions do not apply to lands north and east of the Columbia River, unless TSD activities are initiated there or corrective action activities need to be undertaken there.

The Permittees, in their comments on the second draft of the HF RCRA Permit (DW Portion) issued by Ecology for public review in 1994 (DOE-RL et al. 1994), defined the Hanford Facility as consisting of the contiguous portion of the Hanford Site that contains TSD units and, for the purposes of RCRA, is owned by the U.S. Government and operated by the DOE-RL (excluding lands north and east of the Columbia River, river islands, lands under the exclusive jurisdiction or control by the Bonneville Power Administration, lands leased to the Washington Public Power Supply System, and lands owned by or leased to Washington State) (Figure 2-2).

Exclusion of the noted lands by the Permittees is based on the following rationale. The lands north and east of the Columbia River contain no TSD units. These lands are under consideration for non-U.S. Department of Energy use and for ownership transfer (DOE/EIS-0222). In addition, the DOE-RL has no control over Bonneville Power Administration lands or lands that are owned by or leased to Washington State (e.g., US Ecology site). The U.S. Department of Energy lands leased to the Washington Public Power Supply System are to be covered by a separate dangerous waste permit and, therefore, are not included in the HF RCRA Permit. The legal description of the Hanford Facility, set forth by the Permittees in Appendix $2 \mathrm{C}$, is based on this rationale and is consistent with the facility definition provided to Ecology in 1994 (DOE-RL et al. 1994), with one exception. This exception covers the addition of land now occupied by the Environmental and Molecular Sciences Laboratory. The physical description of the Hanford Facility (including structures, appurtenances, and improvements) is included in Appendix $2 \mathrm{~A}$.

Depending on context, the term 'facility', as used in the Hanford Facility Dangerous Waste Permit Application, also could refer to building nomenclature (Appendix 2B). In this context, the term 'facility' either remains uncapitalized or as part of the title for various TSD units [e.g., 616 Nonradioactive Dangerous Waste Storage Facility (616 NRDWSF)]. 
1 2.1.1.3 Hanford Facility Permitting. This section describes the permitting approach for the Hanford

2 Facility. This approach accommodates requirements established by applicable regulations and authorities,

3 the Tri-Party Agreement, the HF RCRA Permit, and the Hanford Facility Dangerous Waste Permit

4 Application. As noted in the Introduction and Definition Sections of the HF RCRA Permit (DW Portion), the Permit is intended to be consistent with the terms and conditions of the Tri-Party Agreement. Coordination with the Tri-Party Agreement is addressed in Condition I.A.3. of the HF RCRA Permit (DW Portion).

2.1.1.3.1 Applicable Regulations and Authorities. The requirements of RCRA and the State of Washington Hazardous Waste Management Act (as administered through WAC 173-303) pertain to all Hanford Facility units that were used to treat, store, and/or dispose of hazardous waste on or after November 19, 1980; State-only dangerous waste on or after March 12, 1982; mixed waste on or after August 19,1987 ; and units at which such waste will be treated, stored, and/or disposed in the future, except as provided by WAC 173-303-200 and WAC 173-303-802.

Until 1994, none of EPA's RCRA authorizations to Washington State included delegation for HSWA provisions. On January 12, 1994, Washington State submitted a program revision application for additional program approvals related to the corrective action provisions of HSWA. On March 30, 1994, the EPA published a proposal to approve this application in accordance with 40 CFR 271.21(b)(4). On November 4, 1994, the EPA made a final decision that Washington State's hazardous waste program revision satisfies all of the requirements necessary to qualify for final authorization. This decision was based on Washington State's amendment of the Dangerous Waste Regulations to include corrective action requirements. Washington State also can rely on existing 'superfund-like' cleanup authority under the Model Toxics Control Act (MTCA) (as implemented through WAC 173-340, Model Toxics Control Act Cleanup Regulation) (59 FR 55322).

'Dangerous waste' means hazardous, dangerous, or extremely hazardous waste as defined by RCRA and/or WAC 173-303 (refer to Appendix 2B of this document). 'Mixed waste' means waste that contains both dangerous and radioactive components (Appendix 2B). The radioactive component of mixed waste is interpreted by the U.S. Department of Energy to be regulated under the Atomic Energy Act; the nonradioactive dangerous component of mixed waste is interpreted to be regulated under RCRA and WAC 173-303. It is the position of the U.S. Department of Energy that any procedures, methods, data, or information contained in the Hanford Facility Dangerous Waste Permit Application that relate solely to the radioactive component of mixed waste are outside the scope of the permit application and the HF RCRA Permit, but are included for the sake of completeness. It is the position of Ecology that the radioactive component influences safe management of mixed waste and therefore information about this component is necessary to ensure compliance with WAC 173-303 and the HF RCRA Permit. Both agencies acknowledge the other's position, but to avoid a conflict on the issue, the DOE-RL has agreed to provide information on radioactive constituents without agreeing with Ecology's position. Ecology has agreed to accept the information in this context without giving up its position.

The Hanford Facility 'operating' TSD units include, but are not limited to, tank systems, surface impoundments, container storage areas, containment buildings, landfills, and miscellaneous units (refer to Chapter 1.0, Table 1-1) that were, are, or are anticipated to be, involved in dangerous and/or mixed waste activities. The scope of the Unit-Specific Portion is limited to individual 'operating' TSD units for which Part B permit application documentation has been, or is anticipated to be, submitted. However, the scope of the General Information Portion includes information that could be used to discuss 'operating' units, units 'undergoing closure', or units being 'dispositioned through other options'. Unit-specific documentation for TSD units 'undergoing closure', or for units that are, or are anticipated to be, 'dispositioned through other 
options', will continue to be submitted by the Permittees in accordance with the provisions of the Tri-Party Agreement.

In accordance with the stepwise RCRA permitting process defined for the Hanford Facility in the Tri-Party Agreement, those TSD units that are not yet incorporated into the HF RCRA Permit (DW Portion) will continue to operate under interim status. Interim status capacity expansion of the Hanford Facility is in accordance with the provisions of WAC 173-303-281, as applicable, and WAC 173-303-805(7).

Dangerous waste and the dangerous waste component of mixed waste on the Hanford Facility are subject to land disposal restrictions (LDR) (40 CFR 268 and WAC 173-140). Ecology has not received authorization from the EPA to administer LDR provisions of RCRA pursuant to Section 3006 (refer to Section 6.1 of the Tri-Party Agreement Action Plan). When this authorization is received, Ecology will review applicable LDR requirements for purposes of requirements administration.

2.1.1.3.2 Hanford Federal Facility Agreement and Consent Order. The Tri-Party Agreement, as initially established in 1989 and subsequently amended, is a legal document covering Hanford Site environmental compliance and restoration and remediation activities. Reference to the Tri-Party Agreement in the Hanford Facility Dangerous Waste Permit Application refers to the most recent amendment of the document, unless specified otherwise. The Tri-Party Agreement is divided into two parts, the Agreement and Consent Order and the Action Plan.

Purposes of the Tri-Party Agreement as related to RCRA permitting include the following:

- To provide a framework for permitting TSD units and to promote an orderly, effective investigation and cleanup of contamination on the Hanford Site

- To ensure compliance with the RCRA and the State of Washington Hazardous Waste Management Act for TSD units, including requirements covering permitting, compliance, closure, and postclosure care

- To establish a procedural framework and schedule for developing, prioritizing, implementing, and monitoring appropriate response actions on the Hanford Site in accordance with the CERCLA, the National Contingency Plan, the Superfund guidance and policy, RCRA, and RCRA guidance and policy

- To identify TSD units that require permits; to establish schedules to achieve compliance with interim and final status requirements and to complete Part B permit application documentation for such units in accordance with the Tri-Party Agreement Action Plan; to identify TSD units that will undergo closure; to close such units in accordance with applicable laws and regulations; to require postclosure care where necessary; and to coordinate closure with any inter-connected remedial action on the Hanford Site

- To minimize the duplication of analysis and documentation.

The Tri-Party Agreement Action Plan, an enforceable part of the Tri-Party Agreement, establishes methods, procedures, and plans for (1) compliance, permitting, and closure under the RCRA and the State of Washington Hazardous Waste Management Act and (2) cleanup of the Hanford Site under CERCLA and 
1 RCRA corrective action provisions. The Tri-Party Agreement Action Plan also specifies which regulatory agency (i.e., either Ecology or EPA) has lead responsibility.

Appendix B of the Tri-Party Agreement Action Plan contains a listing of Hanford Facility TSD units. In accordance with Section 5.3 of the Tri-Party Agreement Action Plan, any additional TSD units that are identified are to be added to Appendix B. Within the Tri-Party Agreement Action Plan, Section 2.4 and Appendix $D$ include the identification of major milestones established to achieve compliance with RCRA and WAC 173-303 TSD requirements. Such milestones (M) include those for submittal of Part B permit application, closure plan, closure/postclosure plan, and withdrawal request documentation (M-20-00), submittal of preclosure work plan and closure work plan (M-45-06) documentation, installation of RCRA groundwater monitoring wells (M-24-00), and RCRA past-practice site investigations and remedial actions.

In Section 6.2 of the Tri-Party Agreement Action Plan, the permitting process for the over 60 TSD units that comprise the Hanford Facility is described. Figure 2-3, taken from Section 6.2 of the Tri-Party Agreement Action Plan, depicts a flowchart for processing all dangerous waste permitting documentation for 'operating' TSD units by the Permittees. This process applies to existing TSD units, units subject to interim status capacity expansion, and new units (i.e., units that do not have interim status and must have a permit before construction). The process for TSD units 'undergoing closure' is addressed in more detail in Section 2.5. Figure 2-4, taken from Section 6.3 of the Tri-Party Agreement Action Plan, depicts a flowchart for processing closure plan documentation.

The review of each submittal to the regulator is to be conducted in accordance with a process supported by the development of working drafts, project manager meetings, and workshops. In accordance with Section 4.1 of the Tri-Party Agreement Action Plan, project manager meetings are held to discuss progress, address issues, and review plans pertaining to a specific TSD unit. These meetings are held monthly, unless the project managers for the three parties (DOE-RL, Ecology, and the EPA) agree that a meeting is not appropriate. Workshops also are held between the Permittees and the regulators, on an as-needed basis, to address and resolve comments associated with the working drafts.

At the end of the review and comment response process, final documentation is readied for an 'operating' TSD unit and serves as the basis for incorporation of that unit into the HF RCRA Permit (DW Portion). For example, for finalized, TSD unit-specific Part B permit application documentation submitted by the Permittees, a final permit decision will be made by Ecology pursuant to WAC 173-303-840. Specific conditions for this TSD unit will be incorporated into Part III of the HF RCRA Permit (DW Portion) during the next annual Class 3 permit modification (refer to Section 2.1.1.3.3). A process flowchart for modification of the HF RCRA Permit is included as Figure 2-5.

A similar documentation finalization process is in place for TSD units 'undergoing closure' (Figure 2-4), and is discussed in more detail in Section 2.5. Chapter 1.0, Table 1-1, identifies Hanford Facility TSD units that are 'undergoing closure'. Preclosure work plan, closure work plan, closure plan, closure/postclosure plan, or postclosure permit application documentation is to be developed for most of these TSD units in accordance with Sections 2.4, 5.3, 6.3, and 8.0 and Appendix D of the Tri-Party Agreement Action Plan.

Chapter 1.0, Table 1-1 also identifies a number of Hanford Facility TSD units for which procedural closure has been granted, or will be sought, in accordance with Section 6.3 of the Tri-Party Agreement Action Plan or in response to withdrawal requests submitted in fulfillment of Tri-Party Agreement Milestone M-20-45. Procedural closure is used for those units that were classified as being TSD units, but actually 
were never used to treat, store, or dispose of hazardous waste on or after November 19, 1980; State-only dangerous waste on or after March 12, 1982; and mixed waste on or after August 19, 1987, except as provided by WAC 173-303-200 or WAC 173-303-802. Procedural closure is discussed in more detail in Section 2.5.1.3.

2.1.1.3.3 Hanford Facility Resource Conservation and Recovery Act Permit. The initial HF RCRA Permit became effective in September 1994, and is comprised of two portions, a DW Portion and a HSWA Portion.

The HF RCRA Permit (DW Portion) is divided as follows:

Part I-Standard_Conditions. Part I contains conditions that are similar to those appearing in all dangerous waste permits issued by Ecology.

Part II: General Facility Conditions. Part II combines typical DW Portion conditions with those conditions intended to address issues specific to the Hanford Facility. Where appropriate, the General Facility Conditions apply to all final status dangerous waste management activities on the Hanford Facility. Where appropriate, the General Facility Conditions also address dangerous waste management activities that might not be directly associated with distinct TSD units or that could be associated with many TSD units (i.e., spill reporting, training, contingency planning, etc.).

Part III: Unit-Specific Conditions for Operating TSDUnits. Part III contains those permit requirements that apply to each individual TSD unit operating under final status. Conditions for each TSD unit are found in a permit chapter dedicated to that TSD unit. These unit-specific permit chapters contain references to Standard and General Facility Conditions (Parts I and II), as well as additional requirements that are intended to ensure that each TSD unit is operated in an efficient and environmentally protective manner. The Unit-Specific Portion of the Hanford Facility Dangerous Waste Permit Application provides Part B permit application documentation that serves as the basis for Part III chapters of the HF RCRA Permit (DW Portion).

Part IV: Corrective Actions for Past-Practices Activities. Part IV references the HSWA Portion.

Part III of the HSWA Portion, Corrective Action, contains these requirements that apply to the identification of solid waste management units (SWMUs) on the Hanford Facility and conduct of investigations and remediations at such SWMUs. Further discussion of SWMUs is contained in Section 2.5. The corrective action for DOE-RL activities on the Hanford Facility will be as specified in the Tri-Party Agreement. For those SWMUs not covered by the Tri-Party Agreement, RCRA corrective requirements will be addressed by Part III of the HSWA Portion. Thus, the applicability of Part III of the HSWA Portion primarily pertains to those portions of the Hanford Facility where activities are conducted by a lessee or other entity not contractually connected to, and not under the direction of, the DOE-RL.

Subsequent to the issuance of the initial HF RCRA Permit, the EPA delegated HSWA authority for corrective action provisions to Ecology (i.e., on November 4, 1994; refer to Section 2.1.1.3.1). However, all permits issued by the EPA prior to final authorization of Washington State for corrective action will continue to be administered by the EPA until the issuance, or reissuance after modification, of a state RCRA permit (59 FR 55322). Thus, the EPA will continue to administer the corrective action provisions for the Hanford Facility through the HF RCRA Permit (HSWA Portion) until a future modification incorporates these provisions into the DW Portion. At that time, those EPA-issued permit provisions for which Washington 
1 State is authorized will expire; provisions for which Washington State is not authorized will continue in effect 2 under the HSWA Portion.

Part V: Unit-Specific Conditions for TSD Units Undergoing Closure Part V contains those requirements that apply to specific TSD units undergoing closure. Requirements for each TSD unit undergoing closure are found in a permit chapter dedicated to that TSD unit. These unit-specific permit chapters could contain references to Standard Conditions (Part I) and General Facility Conditions (Part II), and additional requirements that are intended to ensure that each TSD unit is closed in an efficient and environmentally protective manner. Further discussion of the permitting process for TSD units undergoing closure' is contained in Section 2.5 .

Part VI: Unit-Specific Conditions for Units in Postclosure Part VI contains requirements that apply to those specific TSD units that have completed (or will complete) modified or landfill closure requirements (refer to Chapter 11.0, Section 11.1.1) and now, or in the future, only need to meet postclosure standards. As set out in Section 5.3 of the Tri-Party Agreement Action Plan, certain TSD units will be permitted for postclosure care pursuant to WAC 173-303 and the HSWA. Requirements for each TSD unit undergoing postclosure care are found in a chapter, within Part VI, dedicated to that unit. These unit-specific chapters could contain references to Standard Conditions (Part I) and General Conditions (Part II), as well as the unit-specific conditions.

The conditions of the HF RCRA Permit (DW Portion) are applied to the Hanford Facility as defined by a Permit Applicability Matrix (Attachment 3, DW Portion) referenced in Condition I.A.1.b. As noted in Condition I.E.2., compliance with the DW Portion constitutes compliance at those areas subject to the HF RCRA Permit for the purpose of enforcement with WAC 173-303-140,-180, -280 through -395, -600 through $-680,-810$, and -830 .

The HF RCRA Permit (DW Portion) is organized to allow a stepwise permitting process as defined in the Tri-Party Agreement. As TSD unit-specific Part B permit application, closure plan, closure/postclosure plan, and postclosure permit application documentation is finalized by the Permittees, and approved by Ecology, additional Unit-Specific Conditions are incorporated into the HF RCRA Permit through the permit modification process.

Modifications to incorporate additional TSD units into the HF RCRA Permit (DW Portion) are conducted in accordance with the Class 3 permit modification procedure specified in WAC 173-303-830 or -840. Except for minor modifications (i.e., Class 1 and Class ${ }^{1} 1$ ), proposed modifications (i.e., Class 2 and 3) are subject to public comment. The permittees may request temporary authorization for Class 2 or 3 modifications in accordance with WAC 173-303-830(4)(e). Condition I.C.3. of the HF RCRA Permit (DW Portion) incorporates a Class 3 Permit Modification Schedule into the HF RCRA Permit (DW Portion) (i.e., Attachment 27). This schedule identifies which TSD units have been, or are to be, incorporated into the HF RCRA Permit (DW Portion) during each annual Class 3 permit modification cycle. Provision of such a schedule supports the planning needs of the Permittees and regulators who process permitting documentation. This schedule also supports the planning needs of the public and affected Indian Tribes who review and comment on this documentation. In summary, the M-20-00 Milestones found in Appendix D of the Tri-Party Agreement Action Plan are complemented by the Class 3 Permit Modification Schedule (Attachment 27) of the HF RCRA Permit (DW Portion). The former specifies when the permitting documentation process for a TSD unit is to be initiated, while the latter specifies when this process is to be finalized. 
The permit modification process is outlined in Figure 2-5. A permit modification does not affect the 10-year term of the HF RCRA Permit [Condition I.C.1. of the HF RCRA Permit (DW Portion)], unless the Permit is revoked and reissued under WAC 173-303-830(3), or terminated under WAC 173-303-830(5), or continued in accordance with WAC 173-303-806(7). In accordance with the stepwise permitting process, only those portions of the HF RCRA Permit (DW Portion) newly proposed for incorporation would be open to public comment. Revocation and reissuance means the existing permit is revoked and an entirely new permit is issued, to include all TSD units permitted as of that date. In this case, all conditions of the permit to be reissued would be open to public comment and a new term would be specified for the reissued permit:

\subsection{Hanford Facility Dangerous Waste Permit Application. The Hanford Facility} Dangerous Waste Permit Application is considered to be a single application organized into a General Information Portion (this document, DOE/RL-91-28) and a Unit-Specific Portion. The scope of the Unit-Specific Portion is limited to individual, 'operating' TSD units for which Part B permit application documentation has been, or is anticipated to be, submitted. Documentation for TSD units 'undergoing closure', or for units that are, or are anticipated to be, 'dispositioned through other options', will continue to be submitted by the Permittees in accordance with the provisions of the Tri-Party Agreement. 'Dangerous waste', as used in the title of the application, refers to waste subject to WAC 173-303 requirements and to requirements of the HSWA, including those for which Ecology has not yet been granted authority by the EPA.

Both the General Information and Unit-Specific portions of the Hanford Facility Dangerous Waste Permit Application address the contents of the Part B permit application guidance documentation prepared by Ecology (Ecology 1987 and 1996) and the EPA (40 CFR 270), with additional information needs defined by revisions of WAC 173-303 and by the HSWA. For ease of reference, the alpha-numeric section identifiers from Ecology's permit application guidance documentation follow, in brackets, the chapter headings and subheadings. Both the General Information and the Unit-Specific portions are organized as follows:

$\begin{array}{ll}\text { - } & \text { Coreword } \\ \text { - Contents } & \\ \text { - Chapter 1.0: } & \text { Part A [A] } \\ \text { - Chapter 2.0: } & \text { Facility Description and General Provisions [B and E] } \\ \text { - Chapter 4.0: } & \text { Process Information [D-1 through D-8] } \\ \text { - Chapter 5.0: } & \text { Groundwater Monitoring for Land-Based Units [D-10] } \\ \text { - Chapter 6.0: } & \text { Procedures to Prevent Hazards [F] } \\ \text { - Chapter 7.0: } & \text { Contingency Plan [G] } \\ \text { - Chapter 8.0: } & \text { Personnel Training [H] } \\ \text { - Chapter 9.0: } & \text { Exposure Information Report } \\ \text { - Chapter 10.0: } 11.0: \text { Closure and Financial Assurance }[1] \\ \text { - Chapter 12.0: } \text { Reporting and Recordkeeping } \\ \text { - Chapter 13.0: Other Federal and State Laws [J] } \\ \text { - Chapter 14.0: } \text { Part B Certification [K] }\end{array}$

A checklist indicating where information is included in either the General Information Portion or the Unit-Specific Portion, in relation to Ecology's permit application guidance documentation, is located in the Contents Section. 
Documentation contained in the General Information Portion is broader in nature and generally applies to multiple TSD units included in the Unit-Specific Portion. Where appropriate, the Unit-Specific Portion makes cross-reference to the General Information Portion, rather than duplicating text. Thus, the General Information Portion could be used by the regulators as a source for both Unit-Specific and General Facility Permit Conditions. To support such use, the General Information Portion is included in its entirety in the "List of Attachments" (i.e., Attachment 33) of the HF RCRA Permit (DW Portion). However, only portions of this attachment will be enforceable. As noted in the Permit, "[O]nly those portions of the Attachments specified in Parts I through VI are enforceable Conditions of this Permit and subject to the Permit modification requirements of Condition I.C.3." The intent of the General Information Portion is: (1) to provide an overview of the Hanford Facility; and (2) to assist in streamlining efforts associated with TSD unit-specific Part B permit application, preclosure work plan, closure work plan, closure plan, closure/postclosure plan, or postclosure permit application documentation development, and the HF RCRA Permit modification process.

2.1.1.4 Hanford Site Missions. Current missions are to safely clean up and manage the legacy wastes on the Hanford Site, and to develop and deploy science and technology (DOE/RL-96-92). To facilitate achievement of these missions, work generally is organized into one of the following projects:

- Tank Waste Remediation System

- Waste Management

- Facility Transition

- Environmental Restoration

- Science and Technology.

A brief discussion of the mission of these projects follows. The TSD units associated with these projects are identified in Chapter 1.0, Table 1-1. 'Operating' TSD units, and their relationship to Hanford's Missions and project missions, are described further in Chapter 4.0. The TSD units 'undergoing closure' or being 'dispositioned through other options' are described briefly in Section 2.5. Project descriptions that follow are based primarily on strategic planning and mission documents (DOE/RL-93-102 and DOE/RL-96-92).

2.1.1.4.1 Tank Waste Remediation System. The Tank Waste Remediation System project mission is to store, treat, and immobilize mixed waste (including current and future tank waste) in an environmentally sound, safe, secure, and cost-effective manner. The project's material management responsibilities include mixed waste stored in the Single-Shell Tank (SST) System and the Double-Shell Tank (DST) System. The primary project disposition responsibilities center on retrieval of both SST and DST waste. Once retrieved, the waste will be immobilized to stable, high-level and low-level forms (Appendix 2B) suitable for disposal.

2.1.1.4.2 Waste Management. The Waste Management Project addresses the handling of solid waste, liquid effluents, and spent nuclear fuel. Two subprojects, Solid Waste Project and 200 Area Liquid Waste Processing Project, currently manage dangerous and mixed waste.

Solid Waste Project. The mission of the Solid Waste Project is to treat, store, and dispose of a wide variety of solid materials that fall into multiple radioactive, dangerous, and mixed waste classes. Material management responsibilities for the Solid Waste Project consist of managing solid waste stored or buried in burial grounds (including retrievable transuranic waste, Appendix 2B) or stored in designated solid waste storage and/or treatment units. The Solid Waste Project also is responsible for managing receipt of newly generated solid waste from onsite generating units and from offsite generators. 
200 Area Liquid Waste Processing Project. The mission of the Liquid Waste Project is to manage current and future Hanford Site liquid effluent streams. The underlying purpose of this Project is to achieve the goal of no longer using the soil column to treat contaminated liquid effluent discharges.

2.1.1.4.3 Facility Transition. The Facility Transition Project mission is to manage facilities such as the PUREX Plant, $\mathrm{UO}_{3}$ Plant, Plutonium Finishing Plant, Fast Flux Test Facility, B Plant, and the former 300 Area Fuel Supply Facility to transition to a deactivated condition. The project will disposition stored nuclear materials. As stored material is dispositioned, the project facilities will be deactivated and transferred to the Environmental Restoration Project for disposition. The project material management responsibilities include managing storage of residual special nuclear material stored in the Plutonium Finishing Plant and stored unirradiated uranium. Management of this material includes responsibility for the facilities used for storage. Many of the activities of the Facility Transition Project are addressed by Section 8.0 of the Tri-Party Agreement Action Plan (refer to Section 2.5.2.1).

2.1.1.4.4 Environmental Restoration. The Environmental Restoration Project is divided into five subprojects: (1) Surveillance/Maintenance and Transition, (2) Decommissioning and N Area Projects, (3) Groundwater Management, (4) Remedial Action and Waste Disposal, and (5) Groundwater and Vadose Zone Integration.

Surveillance/Maintenance and Transition. The Surveillance/Maintenance and Transition subproject is responsible for the disposition of surplus facilities and closure of TSD units. The material management responsibilities of the Surveillance/Maintenance and Transition subproject include the management of existing surplus facilities, including several types of facilities that are no longer in use. The Surveillance/Maintenance and Transition subproject also will be responsible for ultimately receiving additional facilities from all Hanford Site projects to consolidate Surveillance/Maintenance and Transition activities. This responsibility includes establishing the criteria for transferring additional facilities between the Surveillance/Maintenance and Transition portion and the remaining Hanford Site projects. Hence, a key interface exists between the Environmental Restoration Project and Facility Transition Project.

Decommissioning and N Area Projects. The Decommissioning and N Area Project deactivation subprojects are responsible for managing the deactivation and decommissioning of facilities in the $100-\mathrm{N}$ Area. The $\mathrm{N}$ Basin cleanout subproject is separated from the balance of $\mathrm{N}$ Area deactivation and decommissioning activities to focus on completing removal of $\mathrm{N}$ Basin equipment, water, and sludge.

Groundwater Management. The Groundwater Management subproject is responsible for managing and dispositioning groundwater contamination. This contamination has resulted from historical activities. In addition, all groundwater monitoring programs (RCRA, CERCLA, and other environmental programs) are coordinated under this subproject.

Remedial Action and Waste Disposal. The Remedial Action and Waste Disposal subproject is responsible for managing environmental contamination from source areas, including contaminated soils, debris, and other solid waste contained in RCRA, CERCLA, or other TSD units managed under the Environmental Restoration Program. The management responsibilities of this subproject are focused on materials contained in these sites. This subproject is responsible for the design, construction, and operation of the Environmental Restoration Disposal Facility (ERDF). The ERDF is a land disposal facility administered under CERCLA authority meeting the substantive requirements of RCRA and WAC 173-303. 
Groundwater and Vadose Zone Integration. The Groundwater/Vadose Zone/Columbia River subproject's mission is to manage and integrate activities on the Hanford Site that are necessary to provide protection of the water resources of the Hanford Site. A key element of the mission is to infuse sound scientific and technical rationale into the decisionmaking process to provide effective and credible solutions to reduce (or eliminate) the environmental impacts to the vadose zone, groundwater, and Columbia River. The planning and integration of these activities requires active participation by all related DOE-RL project organizations and their respective contractors, as well as Tribal Nations, stakeholders, and regulators. To achieve this mission, the project is committed to several objectives:

- Identify steps needed to establish requirements for all activities to contain contamination and assume protection of groundwater resources and the Columbia River

- Define the process to establish a broad and thorough approach to understanding transport mechanisms and pathways to the Columbia River

- Integrate science, research, and technology development, focused on vadose zone and groundwater remediation, as major components of the Hanford Site's mission

- Establish a strong and effective independent technical review process to include participation by a panel of experts from applicable fields of science and technology, by national laboratories, and by the National Academy of Sciences

- Involve Hanford Site regulators, Tribal Nations, and stakeholders in the development and implementation of the plan.

2.1.1.4.5 Science and Technology. The Science and Technology Project covers a broad spectrum of activities supporting science and technology development. The project responsibilities for management and disposition of materials are limited to quantities associated with past, current, and future development activities.

2.1.1.5 Description of Dangerous Waste Management Operations and Processes. A brief description of dangerous waste management operations and processes for Hanford Facility TSD units is contained in Section 2.5 (for units 'undergoing closure' or being 'dispositioned through other options') and in Chapter 4.0, Section 4.1 (for 'operating' units). Additional detail for 'operating' TSD units is contained in the Unit-Specific Portion.

\subsubsection{Other Processes Regulated Under the Dangerous Waste Regulations. Other Hanford Site} processes or activities regulated under Ecology's Dangerous Waste Regulations include recycling (e.g., WAC 173-303-017,-120,-500), generator activities [e.g., WAC 173-303-170), treatment-by-generator (WAC 173-303-170(3)(b)], transport (e.g., WAC 173-303-240), permits by rule (e.g., WAC 173-303-802), and research, development, and demonstration (RD\&D) permits (WAC 173-303-809). The activities in this section are not included within the scope of this permit application documentation or of the HF RCRA Permit (DW Portion), except where specific language has been included in the Permit.

2.1.1.7 Other Environmental Permits. Other environmental permits that are, or could be, required by the Hanford Facility are addressed in Chapter 13.0. 


\subsubsection{Construction Schedule [B-1b]}

This section addresses the scheduling of construction of new TSD units, or the remodeling of existing units, and the timing of associated permitting activities. Discussions in this section are general, and are based primarily on information contained in WAC 173-303-335, the Tri-Party Agreement, and in U.S. Department of Energy Orders addressing design and construction processes. Additional discussion of construction activities relating to 'operating' TSD units is included in Chapter 4.0.

Existing provisions of the Tri-Party Agreement serve as a means for the timely dissemination to the regulators of construction and associated permitting information that can be used for scheduling purposes. Articles XL and XIVIII of the Tri-Party Agreement outline provisions for DOE-RL to provide cost, schedule, and scope planning and reporting information to Ecology and the EPA. Such information identifies construction activities and schedules related to existing or planned TSD units. In some cases, as outlined in Sections 2.0 and 11.0 and Appendix D of the Tri-Party Agreement Action Plan, construction commitments are associated with Tri-Party Agreement milestones and are tracked as part of milestone statusing activities. Project manager meetings also are used to discuss planned construction, permitting activities, and required timeframes.

Several U.S. Department of Energy Orders establish requirements for the planning and scheduling of construction activities. Requirements to be addressed depend on several factors, including the cost and function of a proposed project. Figure 2-6 provides a generic project schedule keyed to the project process outlined in U.S. Department of Energy Orders. This schedule also illustrates general timeframes for associated permitting documentation. Figure 2-6 illustrates that detailed design information, sufficient to fulfill Part B documentation needs, might not be available until 1 to 2 years before the start of construction. In general, the final status permitting process for a TSD unit of moderate complexity takes at least 3 years. Thus, if a final status permit is required before the initiation of construction, construction delays could be incurred. If such construction is associated with TSD units that are not yet incorporated into the HF RCRA Permit (DW Portion), delays could be avoided by proceeding with construction under interim status or interim status capacity expansion (WAC 173-303-281, -805; refer to Section 2.1.1.3.1). The granting of interim status capacity expansion will be considered on a case-by-case basis, in accordance with WAC 173-303-281, as applicable, and WAC 173-303-805(7).

The generic project schedule shown in Figure 2-6 might not be applicable to TSD units on the Hanford Facility subject to privatization. A discussion of privatization is contained in Section 2.5.1.5.

\subsection{TOPOGRAPHIC MAP [B-2]}

This section addresses general topographic map requirements for the Hanford Facility and additional requirements for land disposal facilities.

\subsubsection{General Requirements [B-2a]}

This section provides topographic and locational information for the Hanford Facility and 'operating' TSD units included in the Unit-Specific Portion. In addition, information on prevailing wind directions and floodplain area is provided. 
1 2.2.1.1 Hanford Facility. Drawing H-6-958 in Appendix 2A provides a general overview of the Hanford

2 Site and surrounding area. The drawing illustrates the following:

3

- Boundary of the Hanford Site (for area shown)

- Contours (at 6.1-meter intervals) sufficient to show surface water flow

- Fire control services

- Access roads, internal roads, railroads, perimeter gates, and barricades

- Longitudes and latitudes.

2.2.1.2 Treatment, Storage, and Disposal Units. General locational maps for Hanford Facility TSD units (refer to Chapter 1.0, Table 1-1) are discussed in Appendix 2A. The specific locations of these TSD units are included in the HF Part A (DOE/RL-88-21). Specific locational information for 'operating' TSD units is contained in topographic maps provided in the Unit-Specific Portion. These maps (unit specific) show a distance of at least 305 meters around the TSD unit, and are often drawn at a scale of 1 centimeter equal to 20 meters $(1: 2,000)$. The contour interval ( 0.5 meter) clearly shows the pattern of surface water flow in the vicinity of each TSD unit. In addition, the following information is included on one or more maps contingent upon scale:
- Map scale
- Date
- Prevailing wind direction
- A north arrow
- Surrounding land use
- Location of the unit
- Access road location
- Access control
- Groundwater monitoring wells (if applicable).
- 100-year floodplain area
- Surrounding land uses
- Location of access control
- Well locations
- Buildings
- Structures (e.g., sewers, loading and unloading areas).

2.2.1.3 Prevailing Wind Directions. Prevailing wind directions across the Hanford Site are presented in Figure 2-7. Prevailing wind directions in the 200 East and 200 West Areas (located approximately in the center of the Hanford Site) are from the northwest in all months of the year. Secondary maxima occur for southwesterly winds.

Monthly average wind speeds are lowest during the winter months, averaging 9.7 to 11.3 kilometers per hour, and highest during the summer, averaging 14.5 to 16.1 kilometers per hour. Wind speeds that are well above average usually are associated with southwesterly winds. However, the summertime drainage winds generally are northwesterly and frequently reach 50 kilometers per hour. Estimates of wind extremes have been summarized (PNL-4622). Information on the likelihood and frequency of strong winds and tornados in the region have been summarized in a final environmental impact statement (DOE/EIS-0113), the Hanford Meteorological Station climatological summary (PNL-4622), and reports from the National Severe Storms Forecast Center. 
2.2.1.4 Floodplain Area. Three sources of potential flooding of the Hanford Facility are considered: (1) the 2 Columbia River, (2) the Yakima River, and (3) storm-induced run-off in ephemeral streams draining the

3 Hanford Facility. No perennial streams occur in the central part of the Hanford Facility.

The Federal Emergency Management Agency has not prepared floodplain maps for the Columbia River through the Hanford Site. The flow of the Columbia River is largely controlled by several upstream dams that are designed to reduce major flood flows. Based on a U.S. Army Corps of Engineers study of the flooding potential of the Columbia River that considered historic data and water storage capacity of the dams on the Columbia River (COE 1969), the U.S. Department of Energy (RLO-76-4) has estimated the probable maximum flood (Figure 2-8). The estimated probable maximum flood would have a larger floodplain than either the 100- or 500-year floods.

The 100-year floodplain for the Yakima River, as determined by the Federal Emergency Management Agency (FEMA 1980), is shown in Figure 2-9.

The only other potential source of flooding of the Hanford Facility is run-off from a large precipitation event in the Cold Creek watershed. This event could result in flooding of the ephemeral Cold Creek. PNL (PNL-4219) has given an estimate of the probable maximum flood using conservative values of precipitation, infiltration, surface roughness, and topographic features. The 100-year flood is less than the probable maximum flood as shown in Figures 2-8 and 2-9.

The location of individual 'operating' TSD units with respect to the identified floodplains is addressed in the Unit-Specific Portion.

\subsubsection{Additional Requirements for Land Disposal Facilities [B-2b]}

For land disposal units, the topographic map or maps (contingent upon scale) indicate the following:

- TSD unit boundaries

- Property boundaries

- Proposed point of compliance

- Proposed groundwater monitoring well locations.

References are provided to publications with maps showing:

- Locations of the uppermost aquifer and aquifers hydraulically interconnected beneath the unit (including flow direction and rate)

- If present, the extent of the plume of contamination that has entered the groundwater from a regulated unit.

Only one Hanford Facility 'operating' TSD unit is classified as a land disposal unit, Low-Level Burial Grounds (LLBG) (refer to Chapter 1.0, Table 1-1). The additional requirements for this TSD unit will be provided through a combination of information contained in the General Information Portion (e.g., in Chapter 5.0) and in the Unit-Specific Portion [e.g., LLBG Part B permit application documentation (DOE/RL-88-20)]. 


\subsection{SEISMIC CONSIDERATION [B-3]}

The Hanford Facility is located in Zone 2B as identified in the Uniform Building Code (ICBO 1991). For a proposed TSD unit or an expansion of an existing unit, a demonstration that the unit is designed to withstand the maximum horizontal acceleration of the "design earthquake" for Zone $2 \mathrm{~B}$ will be made in the Unit-Specific Portion.

No active faults, or evidence of a fault that has had displacement during Holocene times, have been found on the Hanford Facility (DOE/RW-0164). The youngest faults recognized on the Hanford Facility occur on Gable Mountain, approximately 1.6 kilometers north of the 200 East Area, and 7.2 kilometers northeast of the 200 West Area. These faults are of Quaternary age and are considered 'capable' by the U.S. Nuclear Regulatory Commission (NUREG-0892).

\subsection{TRAFFIC INFORMATION [B-4]}

The regional public highway network traversing the Hanford Site (Washington State Highways 24 and 240 ), nonrestricted access roadways (Route 10 , and portions of Route $4 S$ located south of the Wye Barricade), and restricted access roadways are shown in Figure 2-10.

Roadways east of the Yakima Barricade and north of the Wye Barricade, and within the 300 and 400 Areas, are restricted to authorized personnel only. Other U.S. Department of Energy roadways are subject to such restrictions or closure as the U.S. Department of Energy might require.

\subsubsection{Hanford Site Roadways}

Figure 2-10 shows the major roads throughout the Hanford Site. These roads are classified as either primary or secondary routes. The primary routes include Routes $4 \mathrm{~S}, 10,2 \mathrm{~S}, 3,6$, and $11 \mathrm{~A}$, as well as various avenues within each area. The primary routes are constructed of bituminous asphalt (usually 5-centimeters thick, but the thickness of the asphalt layer will vary with each road) with an underlying aggregate base in accordance with U.S. Department of Transportation requirements. The secondary routes are constructed of layers of an oil and rock mixture with an underlying aggregate base. The aggregate base consists of various types and sizes of rock found onsite. The present load-bearing capacities of these roads are unknown; however, loads as large as 9.8 kilograms per square centimeter have been transported without observable damage to road surfaces. All roads originally were constructed to meet the requirements for the American Association of State Highway and Transportation Officials HS-20-44 load rating (AASHTO 1983). An HS-20-44 loading represents a two-axle tractor (front axle loading of 3,630 kilograms and rear axle loading of 14,500 kilograms) plus a single-axle trailer with a 14,500-kilogram axle loading.

\subsubsection{Traffic Control Signs, Signals, and Procedures}

Standard traffic control signs are used throughout the Hanford Site (e.g., octagonal stop signs, triangular yield signs). Speed limits are posted throughout the Hanford Site, and the maximum posted speed is 88 kilometers per hour on major thoroughfares. Inside the various areas, posted speeds are reduced to a maximum of 56 kilometers per hour and held to speeds as low as 24 kilometers per hour. 


\subsubsection{Hanford Site Railroad System}

The general location of rail lines can be found on Figure 2-11 and on Drawing H-6-958 in Appendix 2A. Typically, waste transfers are made during periods of low traffic activity (i.e., between 9:00 a.m. and 3:00 p.m., on weekends, or during off-peak traffic hours). All roads that cross the waste route are barricaded by the Hanford Patrol during waste transfers to prevent motor vehicle accidents. All rail transfers are onsite transfers north of the 1100 Area (Figure 2-11). Based on evaluation of risk, railroad transfers are prohibited during periods of low visibility, when there are winds in excess of 25 kilometers per hour, and during heavy rain, snow storms, or icy conditions.

All railroad track, track beds, and related equipment are maintained to the requirements of Federal Railroad Association track safety standards for Class III track as detailed in 49 CFR 213. Class III track is sufficient for the loads and train speeds on the Hanford Site.

\subsection{WASTE MANAGEMENT UNITS}

This section addresses waste management units (Appendix 2B), including provisions in Section $E$ of Ecology's permit application guidance; Part IV of the HF RCRA Permit (DW Portion); and the HF RCRA Permit (HSWA Portion). The Tri-Party Agreement classifies and outlines the approach for addressing over 2,000 waste management units on the Hanford Site. These waste management units are identified in the Hanford Site Waste Management Units Report (DOE/RL-88-30) (Units Report). The Units Report is updated annually if determined necessary per the Tri-Party Agreement. Because of the comprehensive nature of the Units Report, the list of waste management units is more extensive than that required by Section 3004(u) of HSWA. The classification of Hanford Site waste management units is illustrated in Figure 2-12 and includes the following:

- Solid waste management units

- 'Operating' TSD units

- TSD units 'undergoing closure'

. Non-land disposal TSD units

. Land disposal TSD units

- Past-practice units

- RCRA past-practice

. CERCLA past-practice

- Other SWMUs

- Other waste management units

- Facilities subject to decommissioning

- Miscellaneous waste management units.

The remainder of this section briefly addresses these classes of waste management units, with the exception of 'operating' TSD units. 'Operating' TSD units are addressed in Chapter 4.0, Section 4.1. 


\subsubsection{Solid Waste Management Units [E]}

A SWMU (Appendix 2B) is "any discernable unit at which solid waste has been placed at any time, irrespective of whether the unit was intended for management of solid or hazardous waste. Such units include any area at a facility at which solid waste routinely and systematically has been released [40 CFR 264.501 (proposed)]." The requirements to address SWMUs at a RCRA facility were enacted as part of HSWA [under Section 3004(u), "Continuing Releases at Permitted Facilities"]. The Hanford Site contains approximately 1,100 SWMUs. The remainder of this section, as well as Appendix 2D, provides an overview of Hanford Site SWMUs; with the exception of 'operating' TSD units. An overview of 'operating' TSD units is provided in Chapter 4.0, Section 4.1.

2.5.1.1 Treatment, Storage, and/or Disposal Units 'Undergoing Closure'. This section contains an overview of the documentation process for TSD units 'undergoing closure', as well as a brief description of these units.

2.5.1.1.1 Overview of Treatment, Storage, and/or Disposal Units 'Undergoing Closure'. The Tri-Party Agreement Action Plan defines a TSD as:

"a RCRA term referring to the treatment, storage, or [and/or] disposal of hazardous waste. Under RCRA, TSD activity can occur only at units which received or stored hazardous waste after November 19,1980 , the effective date of the RCRA regulations" (refer to Section 2.1.1.3.1).

Furthermore, the Tri-Party Agreement Action Plan defines a TSD unit as:

"a unit used for treatment, storage, or [and/or] disposal of hazardous waste and is required to be permitted and/or closed pursuant to RCRA requirements as determined in this Action Plan."

Chapter 1.0, Table 1-1, identifies Hanford Facility TSD units that are 'undergoing closure', i.e., TSD units that are no longer active but handled hazardous waste on or after November 19,1980; State-only dangerous waste on or after March 12,1982; mixed waste on or after August 19, 1987; and treated, stored, and/or disposed of such waste, except as provided by WAC 173-303-200 or WAC 173-303-802. Preclosure work plan, closure work plan, closure plan, closure/postclosure plan, or postclosure permit application documentation is to be developed for most of these TSD units in accordance with Sections $2.4,5.3,6.3$, or 8.0 and Appendix D of the Tri-Party Agreement Action Plan. Figure 2-4 depicts a flowchart for processing closure documentation. In accordance with Section 5.3 of the Tri-Party Agreement Action Plan, all TSD units that undergo closure, irrespective of permit status, will be closed in accordance with WAC 173-303-610. Conditions for TSD units undergoing closure are contained in Parts V and VI of the HF RCRA Permit (DW Portion).

For some TSD units 'undergoing closure', it will be possible to remove dangerous waste and waste constituents to Hanford Site background levels (DOE/RL-92-23 and DOE/RL-92-24), as approved by Ecology, or health-based levels defined in accordance with WAC 173-303-610(2)(b), and thereby achieve 'clean closure'. If the waste constituents are at or below agreed to cleanup levels, the TSD unit is considered closed and no further dangerous waste activities are required. For the most part, non-land disposal TSD units (Figure 2-4) will be dispositioned in this manner.

If dangerous waste constituents present at the TSD unit are above MTCA (WAC 173-340) Method B levels, but below MTCA Method C levels, then a 'modified' closure option could be used (refer to 
1 Chapter 11.0, Section 11.1.1.2). Requirements for a modified closure are specified in Condition II.K.3 of the 2 HF RCRA Permit (DW Portion).

3

If levels of dangerous waste constituents are left in place above MTCA Method C levels, TSD units 'undergoing closure' are closed as a landfill (Figure 2-4). Land disposal unit closures are addressed in Section 5.5 and 6.3 of the Tri-Party Agreement Action Plan and WAC 173-303-610. In accordance with Section 6.3.2 of the Tri-Party Agreement Action Plan, units closing as a landfill or under modified closure will require the submittal of a postclosure permit application (i.e., for units "closed as a landfill" Figure 2-4 'transitions' to Figure 2-3, the Permitting Process Flowchart). Where applicable, a postclosure permit application will contain a description of modified closure institutional controls, a description of the landfill final cover, cover maintenance and inspection, groundwater monitoring, and corrective actions if required, that could occur during the postclosure period. Land disposal units 'undergoing closure' most likely will be addressed using the approach discussed in Section 2.5.1.2.

2.5.1.1.2 Description of Specific Treatment, Storage, and/or Disposal Units 'Undergoing Closure'. This section contains a brief description of the TSD units 'undergoing closure'. Information presented in this section has been compiled from existing documents with the primary sources of information as follows: HF Part A, the Tri-Party Agreement, Hanford Site strategic planning and mission documents (DOE/RL-93-102 and DOE/RL-96-92), and the Hanford Site Environmental Permitting Status Report (DOE/RL-96-63). The locations of these TSD units, as well as any operable units cited, are discussed in Appendix 2A. A discussion of 'operable units' is found in Section 2.5.1.2.

2.5.1.1.2.1 207-A South Retention Basin. The 207-A South Retention Basin, located in the 200 East Area, provided interim storage of 242-A Evaporator process condensate before the condensate was discharged to the 216-A-37-1 Crib. The basin consists of three coated, concrete cells with a total capacity of 794,934 liters. The closure plan will be coordinated with the past-practice documentation for the 200-PO-5 operable unit.

2.5.1.1.2.2 216-B-3 Expansion Ponds. The 216-B-3 Expansion Ponds, located in the 200 East Area, consist of three interconnected percolation ponds: $216-\mathrm{B}-3 \mathrm{~A},-3 \mathrm{~B}$, and $-3 \mathrm{C}$. These ponds received cooling water and steam condensate from various 200 East Area buildings. The process design capacity was 105,839,784 liters per day. This TSD unit is included in the HF RCRA Permit (DW Portion, Part V, Chapter 8) and has been clean closed.

2.5.1.1.2.3 216-B-63 Trench. The 216-B-63 Trench, located in the 200 East Area, received mixed waste effluents from the $B$ Plant chemical sewer. The trench also received corrosive dangerous waste from the regeneration of demineralizer columns at $B$ Plant. Treatment of waste occurred by the sequential discharges of acidic and caustic effluents. The process capacity for treatment and disposal was 473,175 liters per day. The closure/postclosure plan will be coordinated with the past-practice documentation for the 200-BP-11 operable unit.

2.5.1.1.2.4 200 West Area Ash Pit Demolition Site. The 200 West Area Ash Pit Demolition Site was used to detonate explosive, ignitable, shock-sensitive, and/or reactive discarded chemical product. The process design capacity for treatment was 568 liters. This TSD unit has been included in the HF RCRA Permit (DW Portion, Part V, Chapter 6) and has been clean closed. 
2.5.1.1.2.5 218-E-8 Borrow Pit Demolition Site. The 218-E-8 Borrow Pit Demolition Site, located in the 200 East Area, was used to detonate explosive, ignitable, shock-sensitive, and/or reactive discarded chemical product. The process design capacity for treatment was 568 liters. This TSD unit is included in the HF RCRA Permit (DW Portion, Part V, Chapter 5) and has been clean closed.

2.5.1.1.2.6 Hanford Patrol Academy Demolition Sites. The Hanford Patrol Academy Demolition Sites, located in the 600 Area, were used to detonate explosive, ignitable, shock-sensitive, and/or reactive discarded chemical product. The process design capacity for treatment was 568 liters. This TSD unit is included in the HF RCRA Permit (DW Portion, Part V, Chapter 9) and has been clean closed.

2.5.1.1.2.7 2727-S Storage Facility. The 2727-S Storage Facility, located in the 200 West Area, stored dangerous waste for eventual shipment offsite. The maximum storage capacity was 102,206 liters. This TSD unit is included in the HF RCRA Permit (DW Portion, Part V, Chapter 3) and has been clean closed.

2.5.1.1.2.8 4843 Alkali Metal Storage Facility. The 4843 Alkali Metal Storage Facility, located in the 400 Area, stored mixed alkali metal waste generated from the Fast Flux Test Facility and various other operations. The maximum design storage capacity was 83,279 liters. This unit is no longer storing dangerous waste. This TSD unit is included in the HF RCRA Permit (DW Portion, Part V, Chapter 12) and has been clean closed.

2.5.1.1.2.9 105-DR Large Sodium Fire Facility. The 105-DR Large Sodium Fire Facility, located in the 100 Areas, was a research laboratory located in the 105-DR Reactor Building. This TSD unit was used to study the behavior of nonradioactive molten alkali metal and fires and treated up to 100 liters per day of alkali metal. Treatment consisted of heating the alkali metals to the point of oxidation. This TSD unit had the capacity to store up to 20,000 liters of dangerous waste. This TSD unit is included in the HF RCRA Permit (DW Portion, Part V, Chapter 10). A portion of the TSD unit has been clean closed in accordance with the approved closure plan. The balance of the TSD unit will undergo decontamination and decommissioning.

2.5.1.1.2.10 3718-F Alkali Metal Treatment and Storage Area. The 3718-F Alkali Metal Treatment and Storage Area, located in the 300 Area, was used to treat and store alkali metal waste from the Fast Flux Test Facility and various laboratories. The alkali metal was treated in a bum shed that oxidized the metal. Used equipment was treated in chemical reaction tanks by dissolving the waste in either water or alcohol. The treatment capacity was 100 liters per day and had a storage capacity of 2,000 liters. This TSD unit is no longer storing or treating dangerous waste. This TSD unit is included in the HF RCRA Permit (DW Portion, Part V, Chapter 13).

2.5.1.1.2.11 304 Concretion Facility. The 304 Concretion Facility, located in the 300 Area, treated and stored pyrophoric waste from the 300 Area fuel fabrication processes. The waste was treated by encapsulation in solid concrete blocks at a rate of 2,082 liters per day. The storage capacity was 4,164 liters. This TSD unit is included in the HF RCRA Permit (DW Portion, Part V, Chapter 11) and has been clean closed.

2.5.1.1.2.12 300 Area Solvent Evaporator. The 300 Area Solvent Evaporator was a treatment tank used to treat mixed waste spent solvents. Containers of spent solvent were stored on a concrete pad adjacent to the evaporator. The treatment capacity for this unit was $\mathbf{8 3 3}$ liters per day, with a storage capacity of 
833 liters. This TSD unit is included in the HF RCRA Permit (DW Portion, Part V, Chapter 2) and has been clean closed.

2.5.1.1.2.13 300 Area Waste Acid Treatment System. The 300 Area Waste Acid Treatment System was used for the storage and treatment of mixed waste generated during the fuel fabrication operations in the 300 Area. The system also was used for disposing of used and/or unneeded chemicals. This system operated in various buildings and tanks throughout the 300 Area. Two treatment processes were used. One treatment process, tank neutralization, had a capacity of 14,006 liters per day. The other treatment process was used to separate the solids from the liquids in the waste. The initial separation process, performed using a centrifuge, had a capacity of 11,356 liters per day; the final separation process, performed using a filter press, had a capacity of 4,542 liters per day. Existing storage capacity was 16,504 liters.

2.5.1.1.2.14 303-M Oxide Facility. The 303-M Oxide Facility, located in the 300 Area, was proposed to be used to treat mixed waste from the 300 Area fuel fabrication process. The waste that was to be treated was pyrophoric chips and fines.

2.5.1.1.2.15 303-K Storage Facility. The 303-K Storage Facility, located in the 300 Area, was used for the storage of mixed waste. Both liquid and solid mixed waste were stored in the unit. The liquid waste was stored within a portion of the $303-\mathrm{K}$ Building. The solid waste was stored outside on an asphalt, concrete, and gravel pad. The storage capacity of this unit was 41,639 liters. This TSD unit is included in the HF RCRA Permit (DW Portion, Part V, Chapter 14).

2.5.1.1.2.16 2101-M Pond. The 2101-M Pond, located in the 200 East Area, received effluents from drains in the 2101-M Laboratory and cooling and heating effluents from the 2101-M Building. The process design capacity was 70,976 liters per day. This TSD unit is included in the HF RCRA Permit (DW Portion, Part V, Chapter 7) and has been clean closed.

2.5.1.1.2.17 Hexone Storage and Treatment Facility. The Hexone Storage and Treatment Facility, located in the 200 West Area, received mixed waste effluents from the REDOX Plant. The mixed waste was stored in two 90,850-liter belowgrade tanks. The waste was treated in a distillation system at a rate of 11,356 liters per day that separated the radioactive component of the waste from the dangerous waste component. The treatment process used railroad cars that had a storage capacity of 151,416 liters.

2.5.1.1.2.18 241-CX Tank System. The 241-CX Tank System, located in the 200 East Area, consists of three tanks (241-CX-70, -71, -72) that stored various mixed wasted streams from the operation of the Hot Semiworks Complex. The combined storage capacity for these tanks is 126,205 liters. The closure plan will be coordinated with the past-practice documentation for the 200-SO-1 operable unit.

2.5.1.1.2.19 183-H Solar Evaporation Basins. The 183-H Solar Evaporation Basins, located in the 100 Areas, were used for the treatment and storage of mixed waste generated by fuels fabrication facilities in the 300 Area. In addition, nonradioactive dangerous waste also was discharged to the basins on a nonroutine basis. The four basins had the capacity of treating 2,650 liters of waste per day by evaporation and capacity to store up to 8,202,962 liters in all four basins. This unit is included in the HF RCRA Permit (DW Portion, Part VI, Chapter 2).

2.5.1.1.2.20 1324-N Surface Impoundment. The 1324-N Surface Impoundment, located in the 100 Areas, was a lined pond with a capacity of $1,514,160$ liters. The unit was used to treat nonradioactive 
1 2

waste effluents from the regeneration of demineralizer columns. Acidic and caustic waste was sequentially added to the pond, which served to neutralize the waste. The closure/postclosure plan for the 1324-N Surface Impoundment will be coordinated with the corrective measures study (CMS) for the 100-NR-1 operable unit.

2.5.1.1.2.21 1301-N Liquid Waste Disposal Facility. The 1301-N Liquid Waste Disposal Facility, located in the 100 Areas, was a percolation unit designed to dispose of liquid waste via the soil column. This TSD unit received radioactive process and cooling waste effluents from $\mathrm{N}$ Reactor for disposal. The unit also received dangerous waste generated from laboratories and may have received waste from spills within the reactor building. The maximum design capacity of the unit was $16,352,900$ liters per day. The closure/postclosure plan for the 1301-N Liquid Waste Disposal Facility will be coordinated with the CMS for the 100-NR-1 operable unit.

2.5.1.1.2.22 1325-N Liquid Waste Disposal Facility. The 1325-N Liquid Waste Disposal Facility, located in the 100 Areas, was a percolation unit designed to dispose of liquid waste via the soil column. This TSD unit received radioactive process and cooling waste effluents from $\mathrm{N}$ Reactor for disposal. The unit also received dangerous waste generated from laboratories and may have received waste from spills within the reactor building. The maximum design capacity of the unit was $16,353,000$ liters per day. The closure/postclosure plan for the 1325-N Liquid Waste Disposal Facility will be coordinated with the CMS for the 100-NR-1 operable unit.

2.5.1.1.2.23 1324-NA Percolation Pond. The 1324-NA Percolation Pond, located in the 100 Areas, received corrosive dangerous waste from the regeneration of demineralizer columns. Acidic and caustic waste was sequentially added to the pond, which served to neutralize the waste. The maximum amount of water discharged to this TSD unit was 3,785,400 liters per day. The closure/postclosure plan for the 1324-NA Percolation Pond will be coordinated with the CMS for the 100-NR-1 operable unit.

2.5.1.1.2.24 100-D Ponds. The 100-D Ponds, a percolation unit located in the 100 Areas, were designed to dispose of liquid waste via the soil column. Approximately 170,343 liters per day were treated. The unit received corrosive dangerous waste from the regeneration of three ion exchange columns and from process water generated from the 183-D Filter Water Plant. Acidic and caustic waste was sequentially added to the pond, which served to neutralize the waste in the pond.

2.5.1.1.2.25 216-S-10 Pond and Ditch. The 216-S-10 Pond and Ditch, a percolation unit located in the 200 West Area, was designed to dispose of liquid waste via the soil column. This TSD unit received waste effluents that consisted of water tower overflow, cooling water, and rainwater. In addition, discharges of dangerous waste to the pond and ditch consisted of simulated DST slurry. This unit was designed to percolate 567,810 liters per day of waste effluents. The closure plan will be coordinated with the past-practice documentation for the 200-RO-1 operable unit.

2.5.1.1.2.26 216-A-29 Ditch. The 216-A-29 Ditch, located in the 200 East Area, was a percolation unit designed to dispose of liquid waste via the soil column. The unit received process and cooling mixed waste effluents from the PUREX Plant and corrosive dangerous waste from the regeneration of demineralizer columns in the PUREX Plant. The process design capacity was $22,712,400$ liters per day. The closure plan will be coordinated with the past-practice documentation for the 200-BP-11 operable unit.

2.5.1.1.2.27 216-B-3 Main Pond. The 216-B-3 Main Pond, a percolation unit located in the 200 East Area, was designed to dispose of liquid waste via the soil column. This TSD unit consisted of the 213-B-3 Main Pond and a portion of the 216-B-3-3 Ditch. The unit received effluents from various 200 East 
1 Area operations, including PUREX Plant, B Plant Complex, 242-A Evaporator, and other units. The types of 2 effluent included process and cooling effluents, chemical sewer effluents, and corrosive dangerous waste from 3 the regeneration of demineralizer columns in the PUREX Plant. Treatment of waste occurred by the 4 sequential discharges of acidic and caustic effluents. The capacity for treatment and disposal for this unit was $53,179,736$ liters per day. The closure plan will be coordinated with the past-practice documentation for the 6 200-BP-11 operable unit.

2.5.1.1.2.28 216-A-10 Crib. The 216-A-10 Crib, located in the 200 East Area, was a percolation unit designed to dispose of liquid waste via the soil column. This TSD unit received process distillate mixed waste effluents from the PUREX Plant. The unit disposed of 272,549 liters per day of waste effluent. The closure plan will be coordinated with the past-practice documentation for the 200-PO-2 operable unit.

2.5.1.1.2.29 216-U-12 Crib. The 216-U-12 Crib, located in the 200 West Area, was a percolation unit designed to dispose of liquid waste via the soil column. This TSD unit received process condensate mixed effluents from the $\mathrm{UO}_{3}$ Plant. The unit disposed of 189,270 liters per day of waste effluents. The closure plan will be coordinated with the past-practice documentation for the 200-UP-2 operable unit.

2.5.1.1.2.30 216-A-36B Crib. The 216-A-36B Crib, located in the 200 East Area, was a percolation unit designed to dispose of liquid waste via the soil column. This TSD unit received mixed waste effluents from the PUREX Plant. The unit disposed of 439,106 liters per day of waste effluents. The closure plan will be coordinated with the past-practice documentation for the 200-PO-2 operable unit.

2.5.1.1.2.31 216-A-37-1 Crib. The 216-A-37-1 Crib, located in the 200 East Area, was a percolation unit designed to dispose of liquid waste via the soil column. This TSD unit received process condensate mixed waste effluents from the 242-A Evaporator. The unit disposed of 327,059 liters per day of waste effluents. The closure plan will be coordinated with the past-practice documentation for the 200-PO-4 operable unit.

2.5.1.1.2.32 300 Area Process Trenches. The 300 Area Process Trenches, a percolation unit, was designed to dispose of liquid waste via the soil column. This TSD unit received process and cooling water from operations in the 300 Area. The unit also received dangerous waste from several research and development laboratories and from the fuel fabrication process. The process trenches were designed to dispose of 11,356,200 liters per day. The closure/postclosure plan has been coordinated with the 300-FF-1 CERCLA documentation.

2.5.1.1.2.33 Nonradioactive Dangerous Waste Landfill. The Nonradioactive Dangerous Waste Landfill, located in the 600 Area, was used for the disposal of nonradioactive dangerous waste. This TSD unit consisted of 19 unlined trenches of which six trenches were used to dispose of dangerous waste, nine trenches were used to dispose of asbestos waste, and one trench was used to dispose of nonhazardous waste. The total design capacity was 6,167 cubic meters. The closure/postclosure plan for the Nonradioactive Dangerous Waste Landfill will be coordinated with the CMS for the 200-IU-3 operable unit.

2.5.1.1.2.34 Simulated High-Level Waste Slurry Treatment/Storage. The Simulated High-Level Waste Slurry Treatment/Storage unit treated and stored a simulated high-level waste slurry. The treatment process consisted of neutralization and immobilization using grout. The unit had a treatment capacity of 757 liters per day and a storage capacity of 75,708 liters. This unit is included in the HF RCRA Permit (DW Portion, Part V, Chapter 4) and has been clean closed. 
2.5.1.1.2.35 224-T Transuranic Waste Storage and Assay Facility. The 224-T TRUSAF is a container storage unit located in the 200 West Area. The 224-T TRUSAF provides a centralized unit for storage of transuranic, transuranic mixed, low-level, and mixed waste (Appendix 2B) from various Hanford Facility operations and from other U.S. Department of Energy and U.S. Department of Defense facilities. The transuranic mixed waste eventually will be transported for disposal at the Waste Isolation Pilot Plant in New Mexico (when this plant becomes operational) or to another approved waste disposal site.

The 224-T TRUSAF currently is managed under the Waste Management Project (Solid Waste Project). The TSD unit will be closed.

2.5.1.1.2.36 1706-KE Waste Treatment System. The 1706-KE Waste Treatment System, located in the 100 Area, was proposed to treat mixed waste generated in the laboratories at the 1706-KE Building. Proposed waste treatment consisted of waste accumulation, mixed-bed resin ion exchange, evaporation, and condensate collection.

2.5.1.2 Past-Practice Units. Section 3.3 of the Tri-Party Agreement Action Plan defines a 'past-practice unit' as a waste management unit where waste or substances (intentionally or unintentionally) have been disposed and that is not subject to regulation as a TSD unit (Appendix 2B) (Figure 2-12). Because of the relatively large number of past-practice units on the Hanford Site, a process has been established for organizing these units into groups called 'operable units' (Appendix 2A). The concept of operable units is to group the numerous units (primarily by type and geographic area) into manageable components for investigation and remedial action and to prioritize the cleanup work to be done on the Hanford Site. Each of the operable units is to be subject to an investigation in the form of either a CERCLA or a RCRA past-practice process as described in Section 7.3 and 7.4, respectively, of the Tri-Party Agreement Action Plan.

As noted in Article III, Article IV, Article XXIV, and Article XXXII of the Tri-Party Agreement, and Sections 3.3, 5.5, and 6.1 of the Tri-Party Agreement Action Plan, some TSD units 'undergoing closure', primarily land disposal units, will be investigated and managed in conjunction with past-practice units; these units have been assigned to appropriate operable units. Those TSD units not assigned to an operable unit are typically treatment or storage units that are likely to be 'clean closed' rather than closed as a land disposal unit (refer to Section 2.5.1.1 and Chapter 11.0). The information necessary for performing RCRA closures within an operable unit will be provided in coordination with various RCRA facility investigation (RFI)/CMS documents (Appendix 2B). These documents will include a coordinated past-practice site investigation/RCRA closure/RCRA corrective action approach in order to efficiently implement applicable regulations. Coordination of the remediation of past-practice operable units with TSD closures will enable RCRA TSD units located within past-practice operable units to have the same cleanup standards. This coordination will minimize the possibility of having different cleanup standards for coincident or adjacent parcels of land.

The coordination approach spelled out in the Tri-Party Agreement Action Plan also is supported by Condition II.K. of the DW Portion of the HF RCRA Permit, "Soil and Groundwater Performance Standards". Condition II.K 7. of the HF RCRA Permit (DW Portion) is particularly relevant. This condition specifies that, when agreed to by Ecology, integration of other statutorily or regulatory mandated cleanups could be accommodated by the HF RCRA Permit (DW Portion). Results from other cleanup investigation activities could be used whenever possible to supplement and/or replace TSD unit closure investigation activities. All, or appropriate parts of, multipurpose cleanup and closure documents could be incorporated into the HF RCRA Permit (DW Portion) through the permit modification process. Cleanup and closures conducted 
under any statutory authority with oversight by either Ecology or EPA, which meets the equivalent of the technical requirements of Condition II.K. of the HF RCRA Permit (DW Portion), could be considered as satisfying the requirements of the HF RCRA Permit (DW Portion). Further discussion of Condition II.K. of the HF RCRA Permit (DW Portion) is contained in Chapters 5.0 and 11.0 of this permit application.

The Tri-Party Agreement requires that the HF RCRA Permit (DW Portion) be the vehicle for the public to become involved in the RCRA past-practice remediation process. Section 7.4 of the Tri-Party Agreement Action Plan contains the information on how the documentation for RCRA past-practice remediation process will be conducted. The milestones to provide the joint documentation of closure/postclosure plans for land disposal units and past-practice operable unit work plans are contained in Appendix D of the Tri-Party Agreement Action Plan. The mechanism for addressing the RCRA past-practice process will be included in a future HF RCRA Permit módification.

2.5.1.3 Procedural Closure. Chapter 1.0, Table 1-1, identifies a number of Hanford Facility TSD units for which procedural closure will be sought in accordance with Section 6.3 of the Tri-Party Agreement Action Plan or in response to withdrawal requests submitted in fulfillment of Tri-Party Agreement Milestone M-20-45. Procedural closure has been approved for three units to date. Procedural closure is used for those units that were classified as being TSD units, but never actually were used to treat, store, or dispose of hazardous waste on or after November 19, 1980; State-only dangerous waste on or after March 12, 1982; and mixed waste on or after August 19, 1987, except as provided by WAC 173-303-200 or WAC 173-303-802. Because another option is being pursued for these units, these units are not included within the scope of the Hanford Facility Dangerous Waste Permit Application. A brief description of the TSD units being considered for procedural closure follows. The locations of these units are discussed in Appendix 2A.

\subsection{1-T Containment Systems Test Facility. The 221-T Containment Systems Test} Facility, located in the 200 West Area, was proposed as a research laboratory to be used to perform experiments with alkali metal compounds. Proposed treatment consisted of heating alkali metal waste in a tank equipped with an offgas system.

2.5.1.3.2 2727-WA Sodium Reactor Experiment Sodium Storage Building. The 2727-WA Sodium Reactor Experiment Sodium Storage Building, located in the 200 West Area, was proposed for storage of 208-liter containers of mixed waste sodium. The sodium to be stored, in metallic form, was used as a primary coolant in a sodium cooled nuclear reactor.

2.5.1.3.3 437 Maintenance and Storage Facility. The 437 Maintenance and Storage Facility, located in the 400 Area, was proposed for maintenance and repair of equipment from the Fast Flux Test Facility. Treatment of dangerous waste was to be conducted by removing residual sodium from waste materials. The process was to consist of placing sodium contaminated material in a tank and reacting surface sodium contamination with water.

2.5.1.3.4 324 Pilot Plant. The 324 Pilot Plant, located in the 300 Area, was proposed for treatment of radioactive alkali metals, including sodium, lithium, and sodium-potassium alloy. Procedural closure was approved on June 9, 1997.

2.5.1.3.5 Biological Treatment Test Facilities. The Biological Treatment Test Facilities, located in the 300 Area, were proposed for treatment of mixed waste via biological treatment $R \& D$ processes. Waste constituents in soil, effluent, and groundwater, through the use of microorganisms, could be treated for 
1 various chemical constituents, such as organics, nitrates, chromium, and cyanide. Procedural closure was 2 approved on December 10, 1996.

2.5.1.3.6 Physical and Chemical Treatment Test Facilities. The Physical and Chemical Treatment Test Facilities, located in the 300 Area, were proposed to test various treatment technologies based on guidance received from EPA and Ecology. Treatment technologies were proposed to include the following:

- pH adjustment

- Ion exchange for selective removal of contaminants from waste solutions

- Waste concentration by evaporation

- Waste dissolution such as waste retrieval from storage tanks by $\mathrm{pH}$ adjustment or fusion

- Precipitation/filtration and solvent extraction from solutions, slurries, and sludges

- Solids washing for separation of contaminants from sludges

- Catalytic destruction methods; for example: electrolytic generation of oxidants such as silver, cerium, and other electrochemically-enhanced processes for decontaminating metals and oxidizing non-metals

- Grouting.

Procedural closure was approved on May 13, 1996.

2.5.1.3.7 Thermal Treatment Test Facilities. The Thermal Treatment Test Facilities, located in the 300 Area, were proposed for treatment of mixed waste via thermal treatment R\&D processes. The primary thermal treatment processes are in situ vitrification and waste vitrification. Other thermal processes were proposed to include the following:

- Plasma arc pyrolysis

- In situ heating of soils and sludges for removal of organics

- Metal melting for volume reduction and immobilization of contaminated metals

- Gamma induced oxidation of organic chemicals

- Thermal treatment for the drying and decomposition of liquid slurries

- In can melting of soil waste and liquid slurries

- Microwave heating to dry and immobilize liquid and solid waste.

Procedural closure was approved on May 13, 1996.

2.5.1.3.8 332 Storage Facility. The 332 Storage Facility, located in the 300 Area, was proposed for the storage of small quantities of mixed and dangerous waste and waste samples in various sized containers from 3.8 to 321.8 liters. Procedural closure was approved on April 21, 1997. 
2.5.1.4 Units with Other Dispositions. This section addresses dispositions for the Fast Flux Test Facility, the 600 Area Purgewater Facility, and the Single-Shell Tank System. The locations of these units are discussed in Appendix 2A.

2.5.1.4.1 Sodium Storage Facility and Sodium Reaction Facility. The 400 Area was developed for the experimentation of breeder reactor technologies, development of isotopes for medical uses, and development and testing of equipment and materials under high radiation fields. The Fast Flux Test Facility (FFTF) was the main reactor used in this experimentation. In 1993, the U.S. Department of Energy announced its decision to shutdown the FFTF. Shutdown began in December 1993-(DOE/RL-93-102) and it was estimated to take about 5 years to place FFTF in an industrially and radiologically safe condition. On January 15, 1997, the Secretary of Energy announced a decision directing that the FFTF be maintained in a standby condition. This will allow the U.S. Department of Energy to determine whether the facility should play a future role in the DOE dual track tritium production strategy and whether it is feasible to use the facility for medical isotope production.

A study to determine if liquid sodium coolant removed from the FFTF has any beneficial use was originally scheduled to be completed in 1998. Due to the decision to maintain FFTF in standby, the decision will be deferred until the final status of FFTF is determined. It is anticipated that one beneficial use for this sodium will be in support of the Tank Waste Remediation System Project. In the event that a beneficial use for the sodium cannot be found, the Sodium Storage Facility and Sodium Reaction Facility will be relied upon to process the sodium for disposal. This TSD unit is being designed and constructed as a RCRA-compliant unit, in the event that the FFTF sodium is determined to be a waste. Additional information on the Sodium Storage Facility and Sodium Reaction Facility is contained in the HF Part A.

Construction of the Sodium Storage Facility under interim status has been completed. The Sodium Reaction Facility will not be constructed until a final decision has been made regarding the disposition of FFTF sodium. When future plans for the Sodium Storage Facility and Sodium Reaction Facility become more definitive, these facilities may be identified as a TSD unit to be added to the HF RCRA Permit (DW Portion) Class 3 Permit Modification Schedule (refer to Chapter 2.0, Section 2.1.1.3.3).

2.5.1.4.2 600 Area Purgewater Storage and Treatment Facility. The 600 Area Purgewater Storage and Treatment Facility is located northeast of the 200 East Area. Liquids associated with groundwater activities and other processes are stored and treated by solar evaporation at the facility. Two above ground modular containment units are located at the facility. Only one of the units is in use. The storage capacity of this single unit is 3,785,400 liters. The facility is permitted per WAC 173-303-400 Interim Status Standards as a chemical, physical, and biological treatment unit per Subpart Q of 40 CFR 265.

The 600 Area Purgewater Storage and Treatment Facility will continue operation as an interim status unit until an alternate disposal pathway can be developed for purgewater. The facility will be closed soon after the development of the alternate pathway.

2.5.1.4.3 Single-Shell Tank System. The SST System, located in both the 200 East Area and 200 West Area, was built to store and treat mixed waste. There are 149 tanks that range in capacity from 208,197 to $3,785,400$ liters with a total storage design capacity of $347,802,552$ liters. Treatment in the system occurs when solids, interstitial liquids, or cooling liquids are removed from the tanks. The treatment design rate is $2,271,240$ liters per day. 
In accordance with Milestone M-45-06 of the Tri-Party Agreement Action Plan, the current estimate for completion of closure of the SST System is September 30,2024. The first closure plan for a SST operable unit or tank farm is scheduled to be submitted to Ecology on November 30, 2004. In the interim period before a closure plan is submitted, a closure work plan was submitted to Ecology (DOE/RL-89-16). This closure work plan will be used by Ecology as a roadmap for the eventual closure of the SST System. The closure work plan contains an integration process and the status of the process on achieving closure. Known issues, and how these issues are being addressed, are included in the work plan. Because of the uncertainties on the resolution of these issues and the closure process, the work plan will evolve and be updated as these uncertainties are resolved. Eventually, the closure work plan will develop into the closure plan. The format of the closure work plan is similar to a closure plan. The areas covered in the work plan include waste retrieval, operable unit characterization, technology development to support closure, and the regulatory pathway and strategy for achieving closure.

2.5.1.5 Privatization. This section addresses privatization associated with TSD units. The term 'privatization' (Appendix 2B) refers to vendors, under contract with the U.S. Department of Energy, using private funding to design, permit, construct, operate, and deactivate their own equipment and facilities to treat tank waste. Currently, development of low-activity and high-level waste pretreatment and immobilization facilities are identified as being subject to privatization. These facilities are proposed to supersede the Grout Treatment Facility and the Hanford Waste Vitrification Plant. Thus, work to proceed with the Grout Treatment Facility and the Hanford Waste Vitrification Plant has been suspended. The locations of these units are discussed in DOE/RL-88-21.

2.5.1.5.1 Grout Treatment Facility. The GTF, located in the 200 East Area, is classified as a tank treatment and storage, a surface impoundment, a miscellaneous treatment, and a land disposal unit. Per Amendment Four of the Tri-Party Agreement, the GTF has been placed in a standby mode until other alternatives for processing DST System waste are studied. The GTF was to treat DST System waste by combining this waste with grout-forming solids and, if necessary, chemical additives. The treatment process forms a cementious slurry that was to be pumped to lined concrete disposal vaults. The disposal vaults were to be managed as surface impoundments when the grout slurry was liquid and closed as landfills after the grout slurry hardened. Part B documentation for the GTF is contained in the Unit-Specific Portion of this permit application (DOE/RL-88-27). The GTF will remain under interim status as long as this TSD unit is in a standby mode. Further work on Part B documentation for the GTF has been suspended while this TSD unit is in a standby mode.

Low-activity waste immobilization facilities have been proposed to supersede the GTF. Development of low-activity waste immobilization facilities currently is being managed under the Tank Waste Remediation System Project. As currently planned, the GTF disposal vault will be used for the interim storage of the immobilized low-activity waste product produced by the privatization contractor. The disposal vault would continue to be operated by the Tank Waste Remediation System Project. Part B permit application documentation for storage of the low-activity waste product is scheduled to be submitted by December 2000 .

2.5.1.5.2 Hanford Waste Vitrification Plant. Under milestones set in the original Tri-Party Agreement, construction of the HWVP was to begin in 1992 and to be completed in 1998. The HWVP, designed to meet the original Tri-Party Agreement milestones, is classified as a tank treatment and storage, a container storage (canister storage building), and a miscellaneous unit. Per Amendment Four of the Tri-Party Agreement, construction of a high-level waste vitrification plant, such as the HWVP, was delayed until 2002 to accommodate changes in waste management planning and prioritization. Hot startup of a high-level waste vitrification plant has been delayed until 2009 (per Tri-Party Agreement Milestone M-51-03). 
The HWVP was to be constructed in the 200 East Area (DOE/RL-88-21). Mixed waste, received from a pretreatment unit, was to be treated at the HWVP in a series of tanks and a melter, classified as a miscellaneous unit. Treatment was to include concentration by evaporation, adjustment with chemicals and glass forming materials, and immobilization in borosilicate glass (vitrification). Part $\mathrm{B}$ documentation for the HWVP is contained in the Unit-Specific Portion of this permit application (DOE/RL-89-02). Further work on this documentation has been suspended. Current plans call for a high-level waste immobilization facility.

Development of a high-level waste immobilization facility currently is being managed under the Tank Waste Remediation System Project. As currently planned, the immobilized high-level waste product will be stored in the Canister Storage Building. Part B permit application documentation for the Canister Storage Building is scheduled to be submitted by December 2000 .

2.5.1.6 Other Solid Waste Management Units. The HF RCRA Permit (HSWA Portion) addresses both SWMUs that are located on the DOE-RL-managed property of the Hanford Facility as well as SWMUs that are not located on DOE-RL-managed property. In accordance with the HF RCRA Permit (HSWA Portion), any SWMUs located on DOE-RL-managed property are, or will be, included in the Tri-Party Agreement and assigned to operable units. The processes and procedures to be followed, and the schedules of compliance for investigation and subsequent remediation, will be contained in the Tri-Party Agreement. An example of a type of 'other SWMU' is inactive miscellaneous underground storage tanks.

The SWMUs not located on DOE-RL-managed property will undergo investigations and remediations, as necessary, in accordance with the requirements and schedules identified in the HF RCRA Permit (HSWA Portion). Additional information on Hanford Site SWMUs is contained in Appendix 2D.

\subsubsection{Other Waste Management Units}

Of the approximately 1,600 Hanford Site waste management units, approximately 470 are classified as 'other waste management units', rather than SWMUs (DOE/RL-88-30). These 'other waste management units' are comprised mainly of one-time spills to the environment, sanitary waste disposal facilities (i.e., septic tanks), and facilities managed or addressed by the Facility Transition or Environmental Restoration Projects.

2.5.2.1 Facilities Subject to Decommissioning. This section addresses waste management units that could be handled under Section 8.0 of the Tri-Party Agreement Action Plan, "Facility Decommissioning Process," or under the HF RCRA Permit (DW Portion). Section 8.0 defines an additional process for the identification and decommissioning of key Hanford facilities (e.g., PUREX Plant, Plutonium Finishing Plant, B Plant Complex, Fast Flux Test Facility) (Appendix 2A). Facilities that are fully dispositioned under the TSD unit closure process, or dispositioned in conjunction with an operable unit cleanup, are not addressed under Section 8.0. The TSD units subject to Section 8.0 have physical closure actions that need to be done in conjunction with the physical disposition actions in the facility (e.g., removal of structural components).

Section 8.0 of the Tri-Party Agreement Action Plan enables DOE-RL and the regulators to enter into negotiations for transition or disposition of key facilities within 3 months of a shutdown notice or decision to proceed with disposition, respectively. Provisions of this section enable the conduct of regulated and nonregulated work in an orderly sequence to ensure coordination with other cleanup actions. Within Section 8.0, the processes and key planning documents associated with the decommissioning phases of transition, surveillance and maintenance, and disposition are defined. 
The nature of the decommissioning process has led DOE-RL and the regulators to evaluate the timing of RCRA closure at key facilities. The phased decommissioning process, combined with other requirements, often makes completion of RCRA closure activities during the transition or surveillance and maintenance phases impracticable. In cases where timely completion of TSD unit closure is practicable, a complete closure plan will be prepared for implementation during the transition phase. In cases where physical conditions and/or unknowns prevent timely completion of closure, a preclosure work plan will be prepared for implementation during the transition phase. The preclosure work plan will detail actions to be completed during the transition phase to facilitate full RCRA closure in the future.

Hanford Facility TSD units that are, or may become key Hanford facility units, subject to Section 8.0 of the Tri-Party Agreement Action Plan, are identified in Chapter 1.0, Table 1-1. In these cases, TSD unit-specific conditions within Parts III and V of the HF RCRA Permit (DW Portion) will need to be crafted to address Section 8.0 considerations. The SST System will not follow Section 8.0 of the Tri-Party Agreement Action Plan, but will instead be addressed in accordance with the Single-Shell Tank Closure Work Plan (DOE/RL-89-16).

2.5.2.1.1 PUREX Plant. The PUREX Facility, located in the 200 East Area, consists of two separate TSD units, the PUREX Plant (202-A Building) and the PUREX Storage Tunnels (refer to Chapter 4.0, Section 4.1.2.11). The PUREX Plant is a canyon building that was used for the recovery of uranium and plutonium from irradiated reactor fuel. Liquid-liquid processes were used to separate the plutonium and uranium from fission products and to separate the plutonium from the uranium.

In 1991, the PUREX Plant ceased operations and was placed in a standby mode. In December 1992, the U.S. Department of Energy notified DOE-RL that the PUREX Plant would no longer operate and directed the PUREX Plant to transition into deactivation. In accordance with Section 8.0 of the Tri-Party Agreement Action Plan, a preclosure work plan (DOE/RL-95-78) has been submitted to address those components of the PUREX Plant contained in the Part A, Form 3, permit application documentation for this unit. The PUREX Storage Tunnels (DOE/RL-90-24) will continue to store mixed waste for an undetermined number of years, and are classified as an 'operating' unit (refer to Chapter 4.0, Section 4.1.2.11).

2.5.2.1.2 241-Z Treatment and Storage Tanks. The 241- $Z$ is a tank treatment and storage unit located in the $241-Z$ Building in the 200 West Area. Mixed waste generated at the Plutonium Finishing Plant is transferred into the $241-Z$ treatment and storage tanks. Waste accumulated in the tank system is treated chemically to meet acceptance criteria for transforring waste to the DST System. Treatment consists of chemical additions to adjust $\mathrm{pH}$, to ensure aluminum compounds remain solubilized, and to provide the appropriate percentage of stable solids. Following treatment, the waste is stored until authorization is received to transfer the waste to the DST System.

The 241-Z currently is managed under the Facility Transition Project. Permitting documentation for this TSD unit could be handled in accordance with Section 8.0 of the Tri-Party Agreement Action Plan. The $241-Z$ will continue to operate under interim status. A closure plan has been submitted for this TSD unit (DOE/RL-96-82).

2.5.2.1.3 B Plant Complex. The B Plant Complex is a tank treatment and storage, container storage, and containment building unit located in the 200 East Area. The B Plant Complex current activities include storage of low-level mixed waste and containerized non-liquid mixed waste. Solid mixed waste is stored on the canyon deck. A low-level waste concentrator currently is inactive with no intention of resuming operations. Solid mixed waste stored on the canyon decks consists of radioactively contaminated failed 
process equipment and jumpers (or isolated components thereof) containing lead used as weights, counterweights, or radiation shielding. The solid mixed waste also could be contaminated with residues from waste processing of tank waste.

The B Plant Complex currently is managed under the Facility Transition Project. Permitting documentation for this TSD unit will be handled in accordance with Section 8.0 of the Tri-Party Agreement Action Plan.

2.5.2.1.4 Waste Encapsulation and Storage Facility. The Waste Encapsulation and Storage Facility (WESF) is a miscellaneous storage unit located in the 200 East Area adjacent to B Plant. The WESF TSD unit consists of several hot cells and pool cells providing capacity for the storage of cesium and strontium capsules and unencapsulated salts, for which no commercialization contract exists. In the past, some of the cesium capsules have been used in private industry as irradiation sources.

Currently, approximately 1,900 capsules (1,300 cesium and 600 strontium) are stored in the WESF TSD unit. It also is anticipated that cesium salts currently located in the 300 Area will be overpacked and shipped to WESF for continued storage. It is expected that the capsule material will be dispositioned with the DST System tank waste vitrification unless a viable use is identified. Should a viable use be identified, the recycling/reuse provisions of WAC 173-303-017 would be applied to eliminate the solid waste designation of the useable portion of the inventory.

WESF is managed by the Facility Stabilization Project and has prepared Part A documentation for interim status operation. It is expected that Part B documentation may be prepared at some date in the future, but discussions between DOE-RL and Ecology are still ongoing and no schedule has been established for this effort.

2.5.2.1.5 Fast Flux Test Facility. Pending permitting considerations associated with the Fast Flux Test Facility are addressed in Section 2.5.1.4.1.

2.5.2.2 Miscellaneous Waste Management Units. Examples of miscellaneous waste management units are one-time spills to the environment and sanitary waste disposal facilities (i.e., septic tanks). All such known units are identified in the Units Report (DOE/RL-88-30). The term "miscellaneous waste management unit" used in this context is different from that defined in WAC 173-303-040 for a "miscellaneous TSD unit" (refer to Appendix $2 \mathrm{~B}$ of this document). 
DOE/RL-91-28, Rev. 4 $05 / 98$

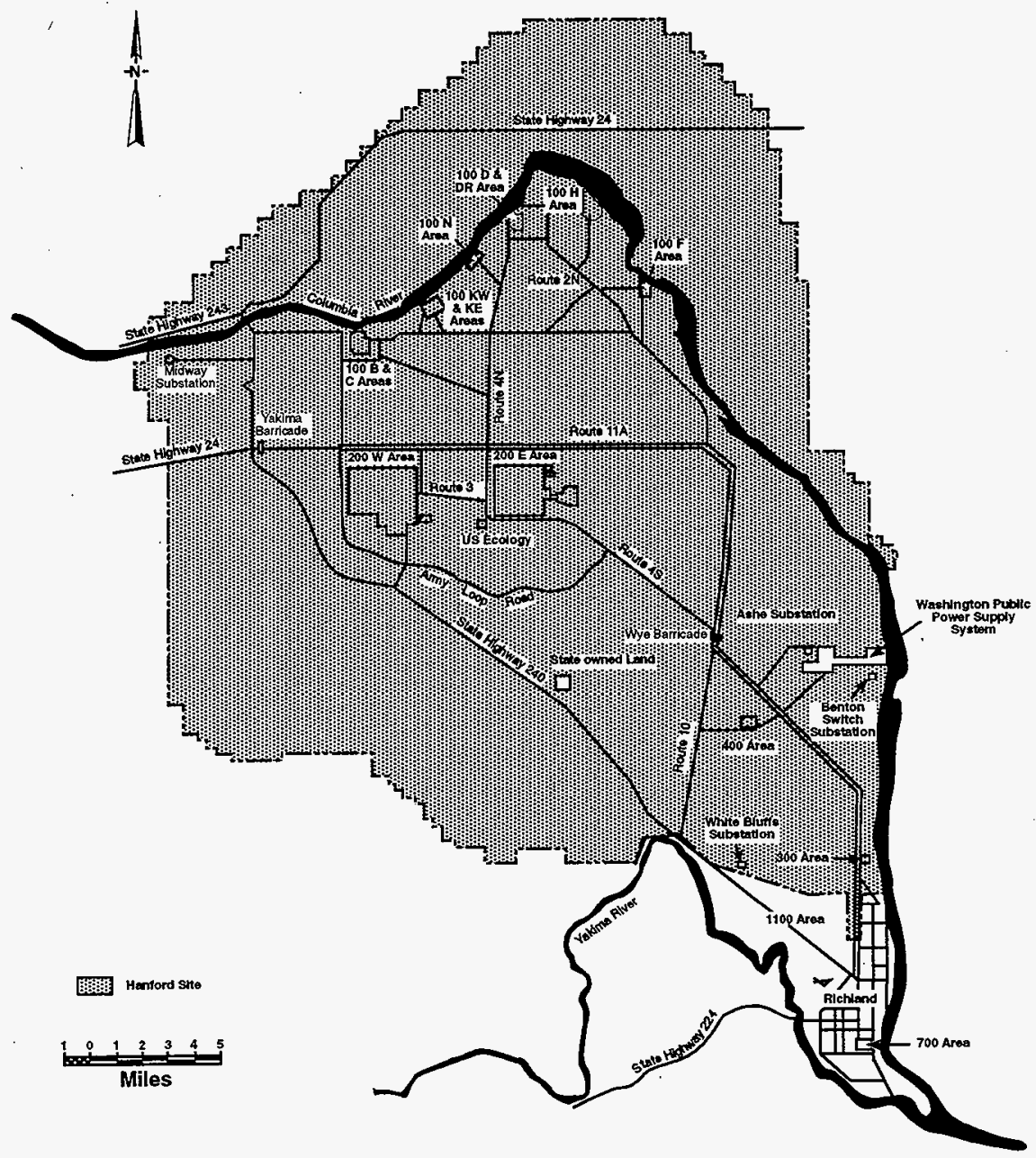

H97020271.2

Figure 2-1. Hanford Site [coincides with Hanford Facility boundary as defined in the HF RCRA Permit (DW Portion), Attachment 2]. 
DOE/RL-91-28, Rev. 4 $05 / 98$

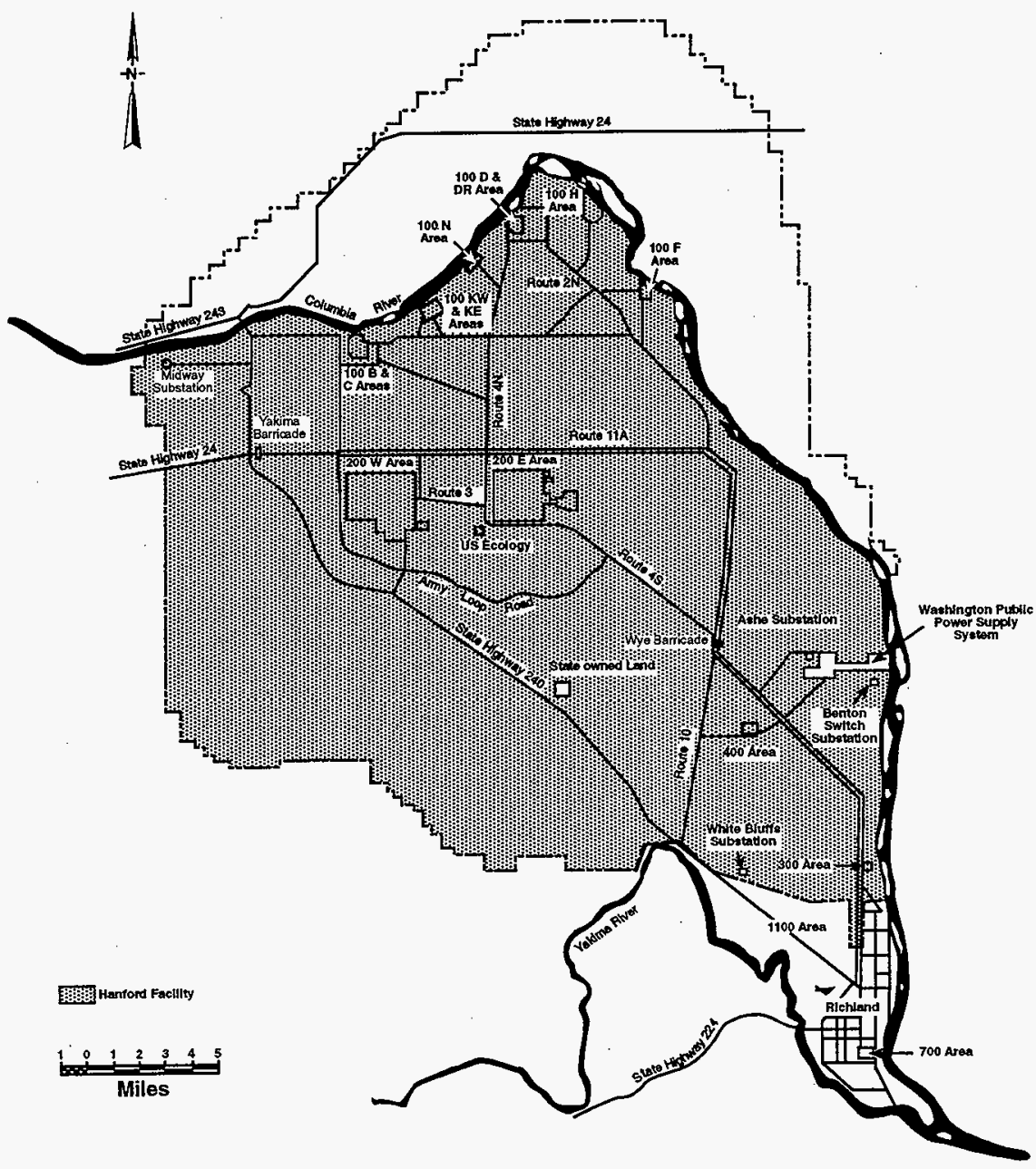

H97020271.1

Figure 2-2. Hanford Facility Boundary (as defined in Appendix 2C, Legal Description). 


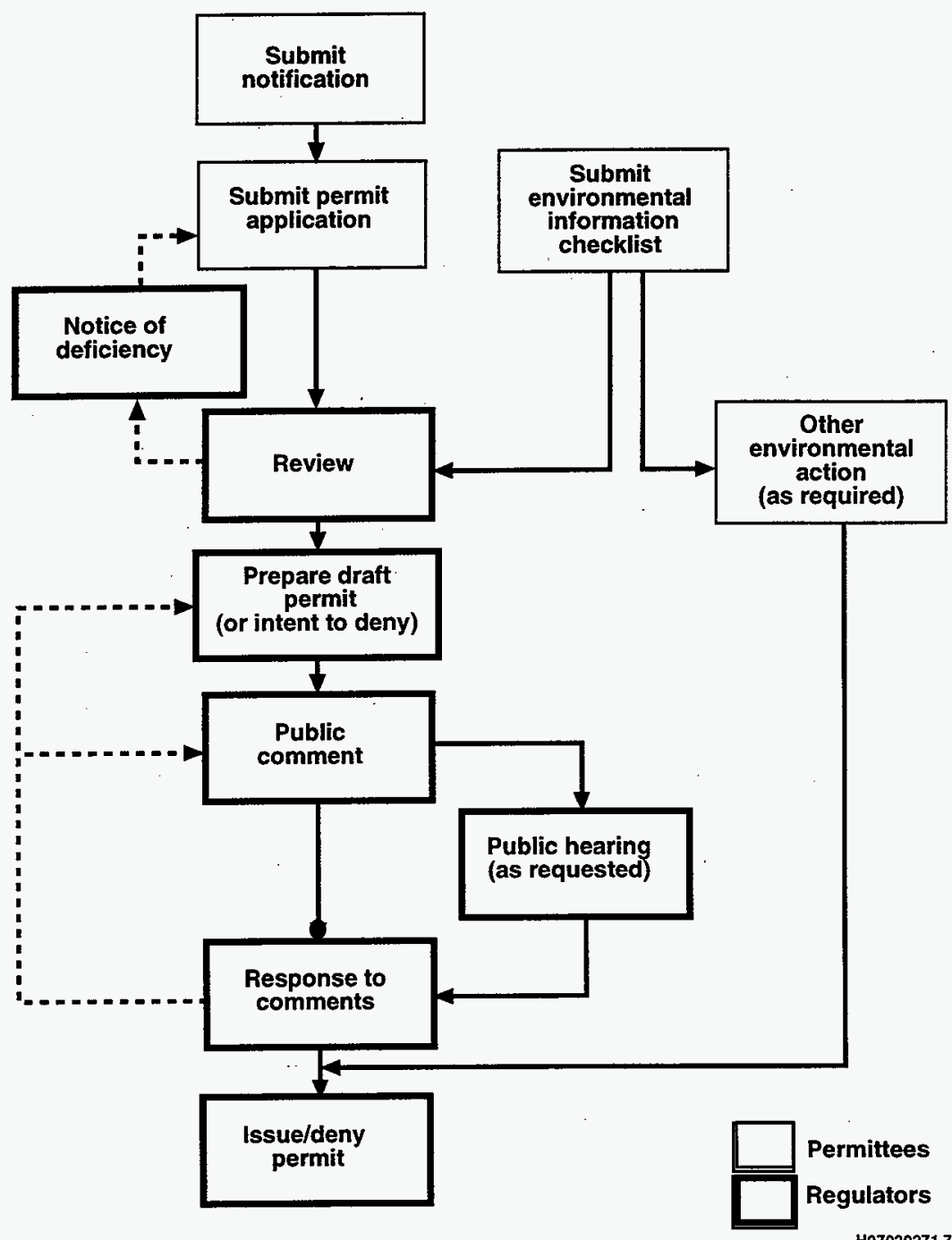

H97020271.7

Figure 2-3. Permitting Process Flowchart (adapted from Tri-Party Agreement). 


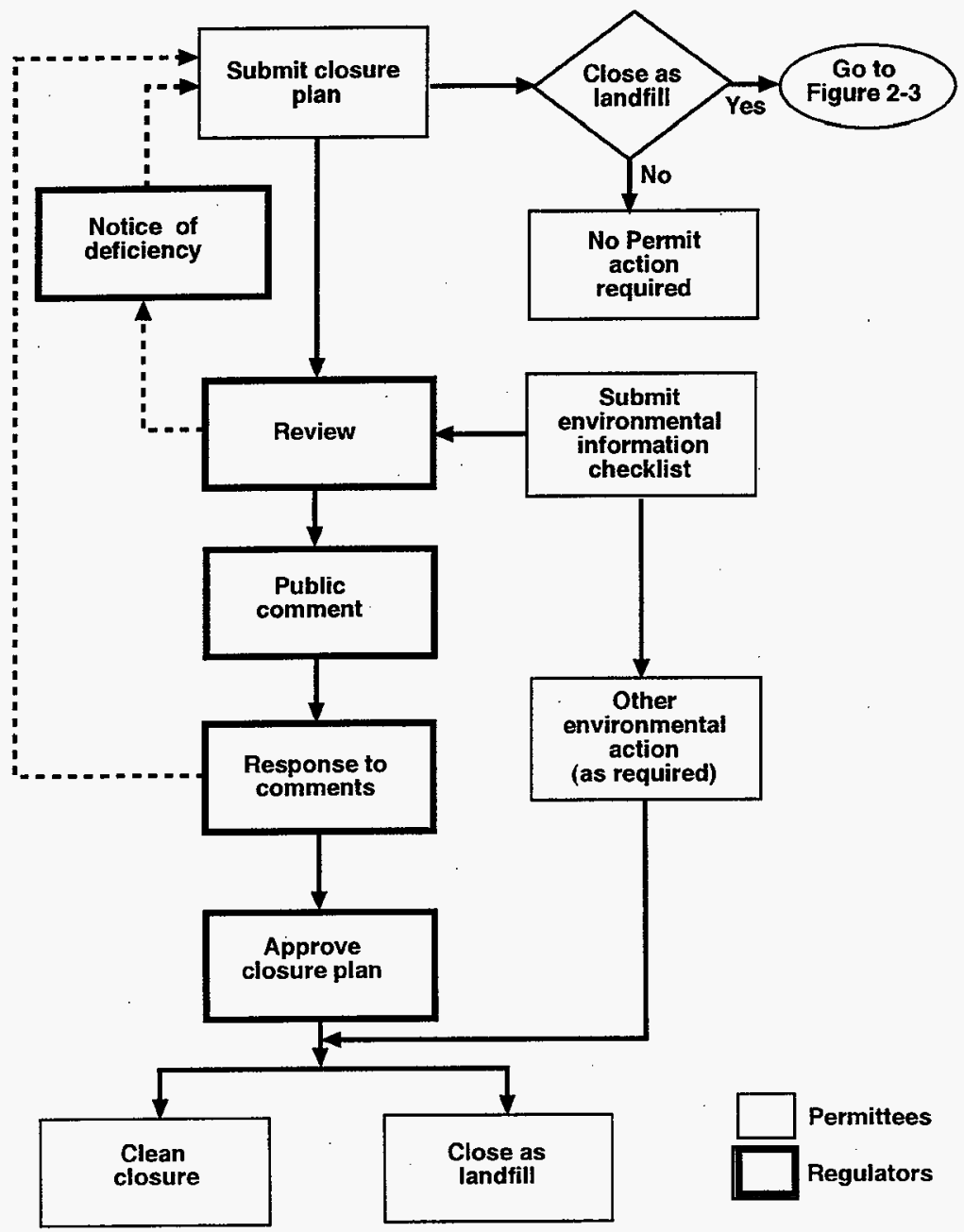

H97020271.6R1

Figure 2-4. Closure Process Flowchart (adapted from Tri-Party Agreement). 


\section{RCRA Permitting Flow Chart}

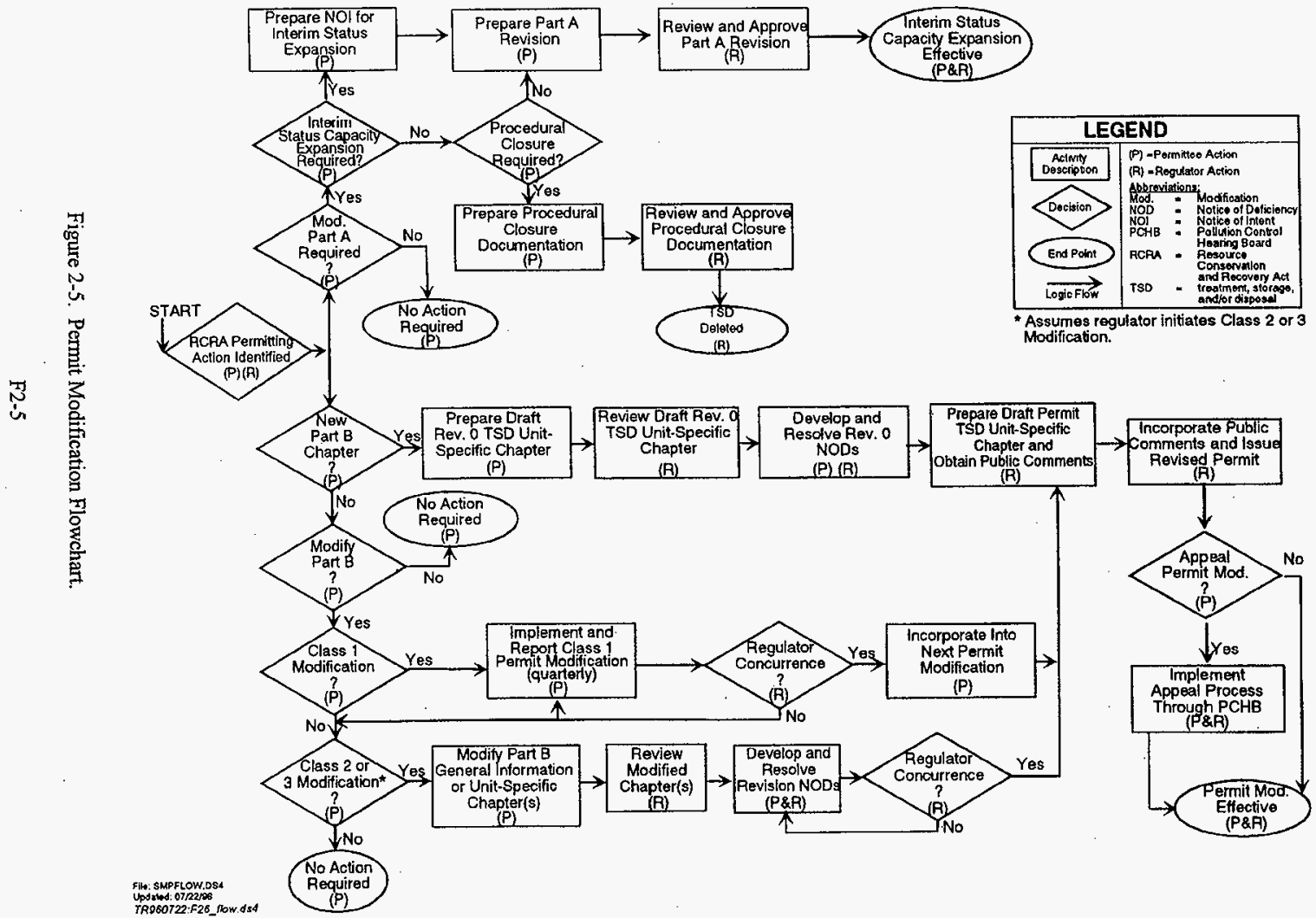




\section{Regulatory Requirements for Generic Project Schedule}

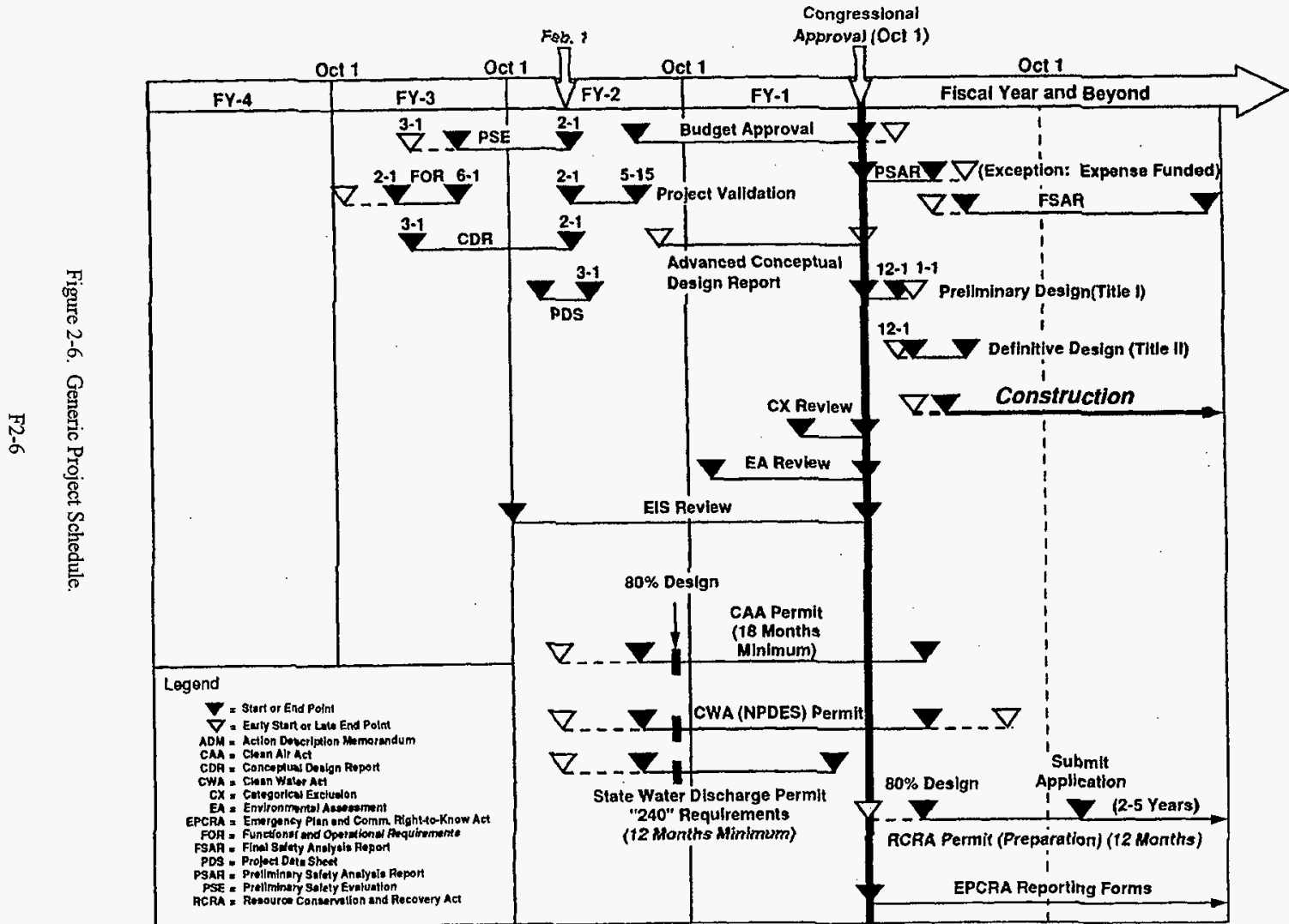




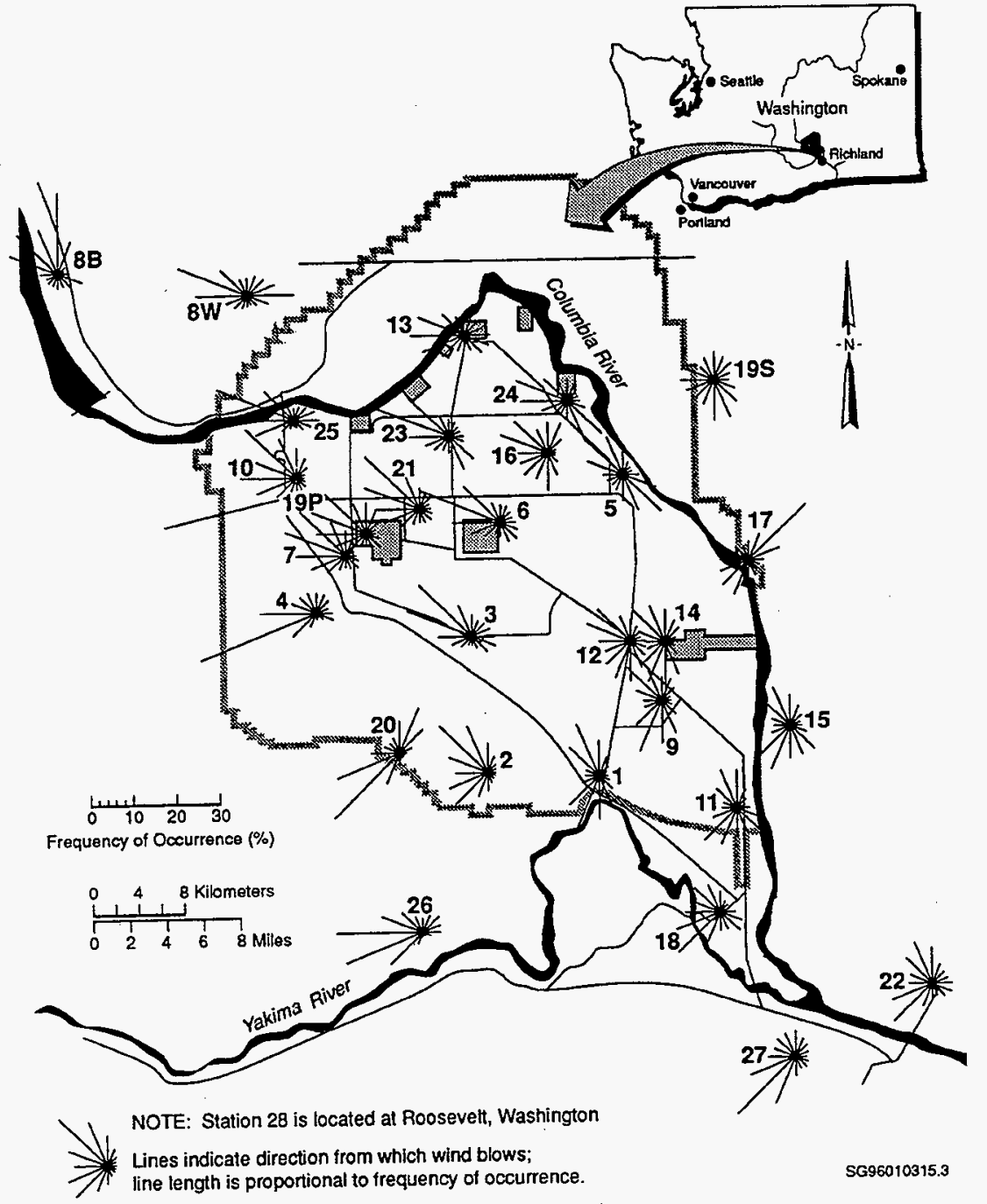

Figure 2-7. Prevailing Wind Direction for the Hanford Site (adapted from PNNL-11139). 
DOE/RL-91-28, Rev. 4

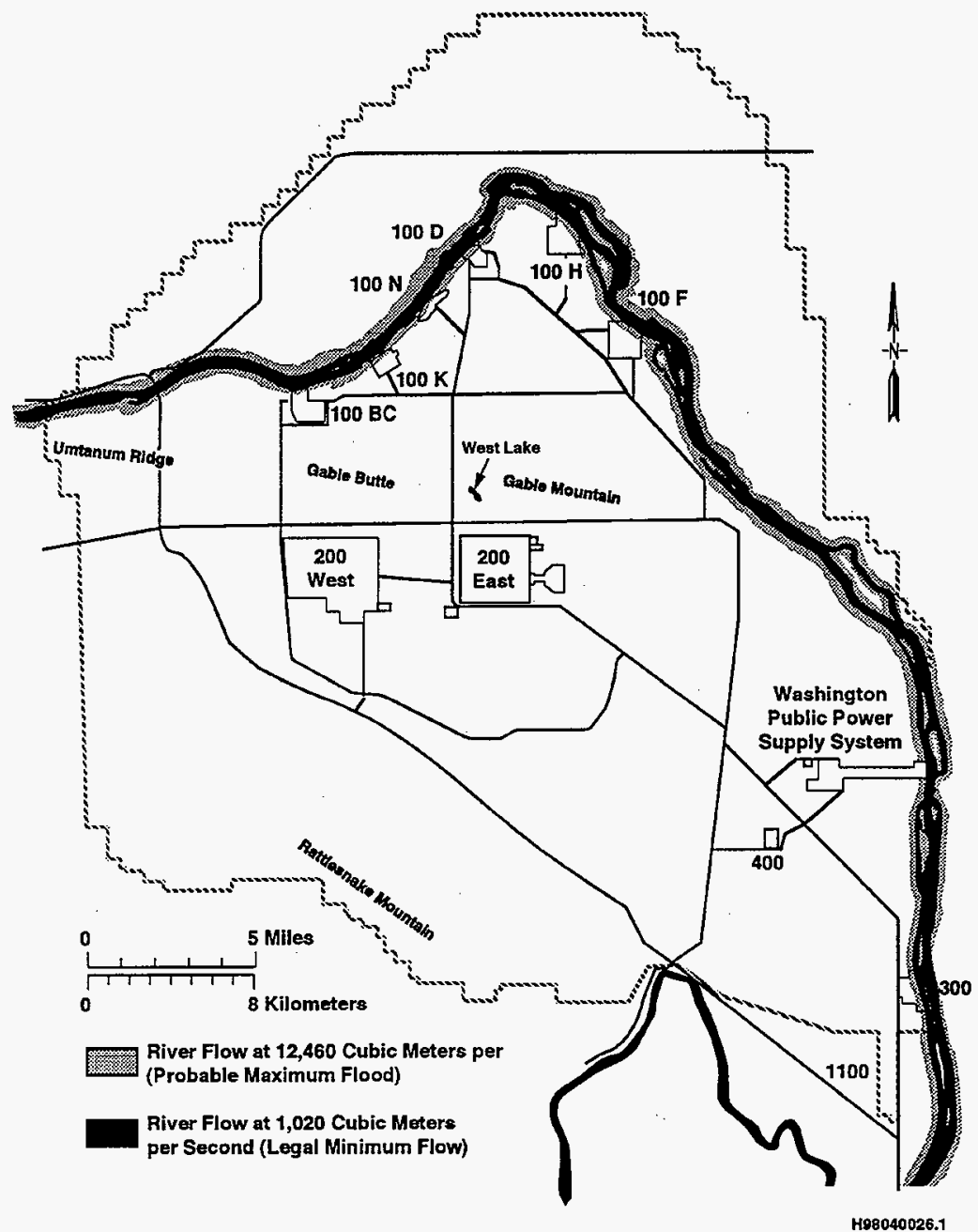

Figure 2-8. Columbia River Floodplain (probable maximum flood) (adapted from DOE/EIS-0222). 


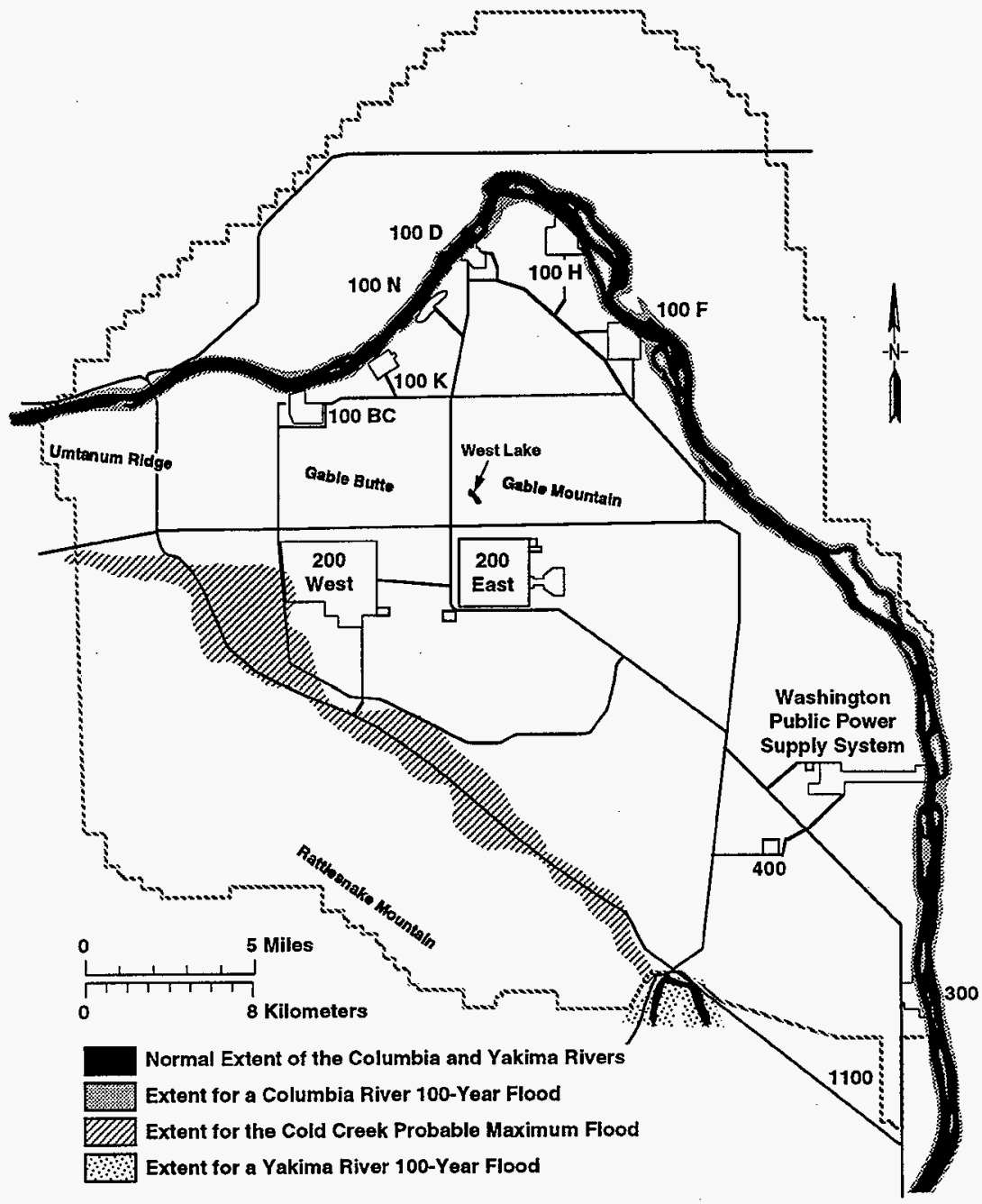

H96050316.4b

Figure 2-9. 100-Year Floodplain of the Columbia River and Yakima River and the Cold Creek Probable Maximum Flood (adapted from DOE/EIS-0222). 


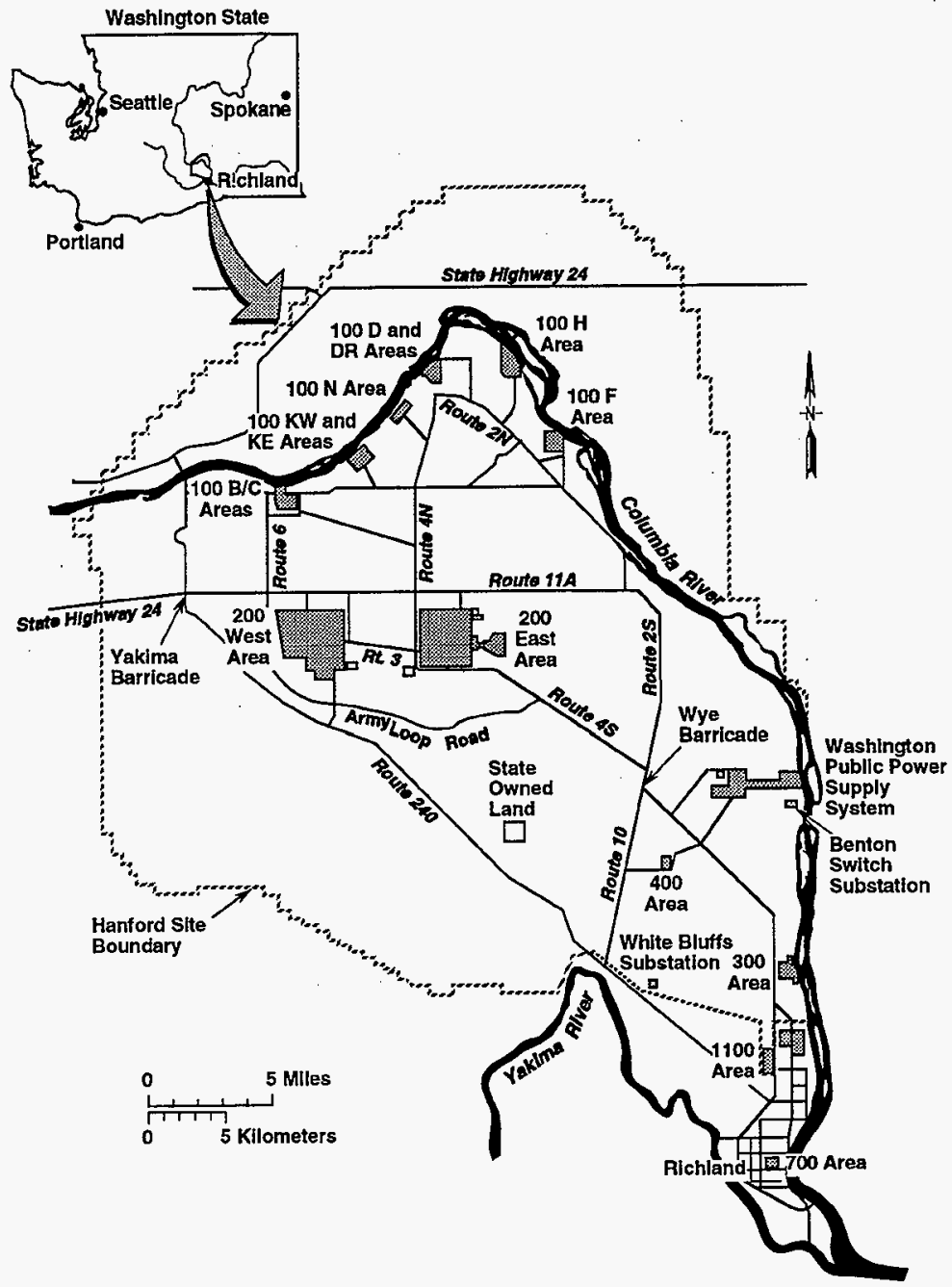

H97020271.4

Figure 2-10. Hanford Site Roadways (adapted from DOE/EIS-0222). 


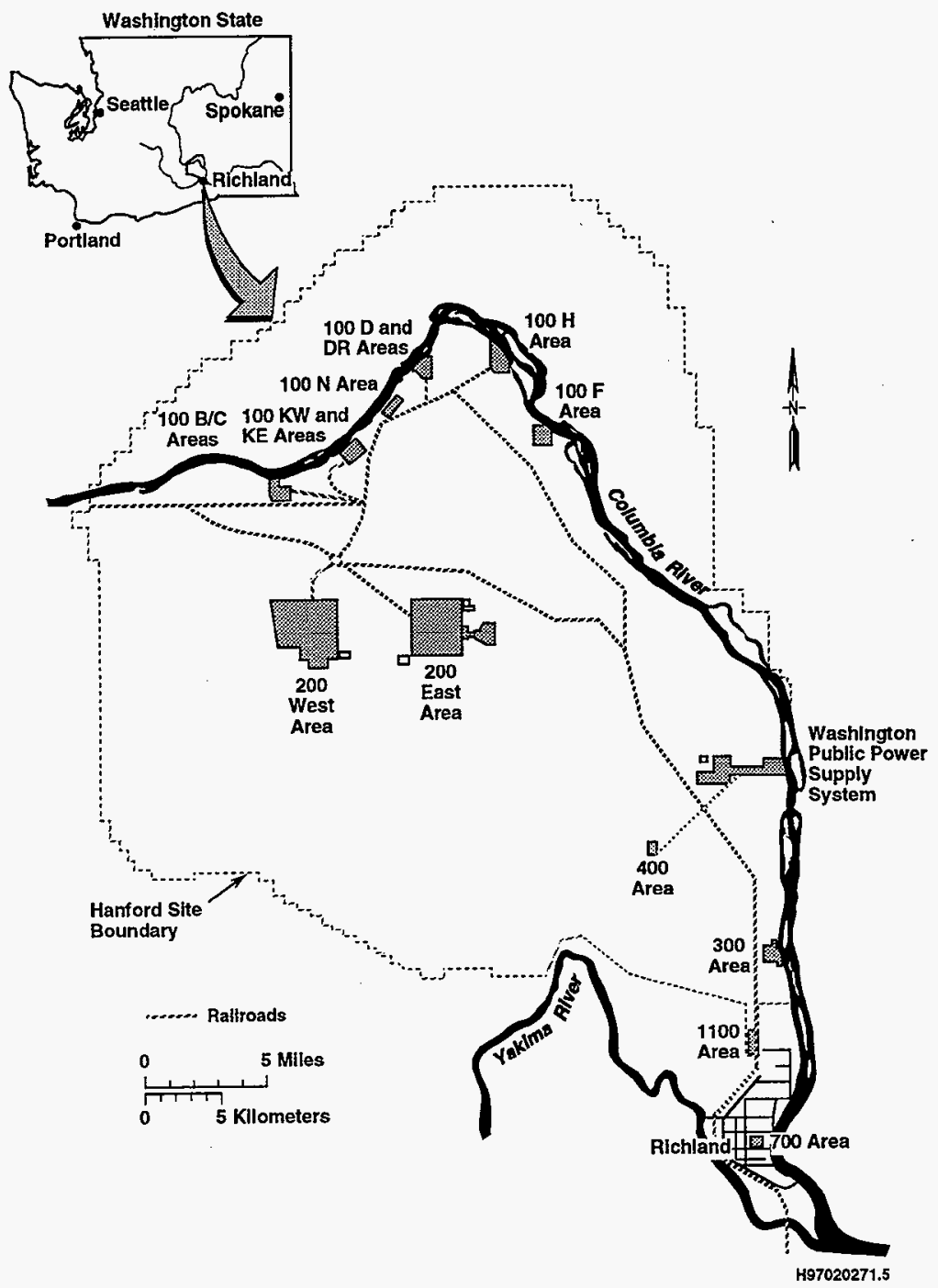

Figure 2-11. Hanford Site Railroad System (adapted from DOE/EIS-0222). 


\section{Classification of Waste Management Units}

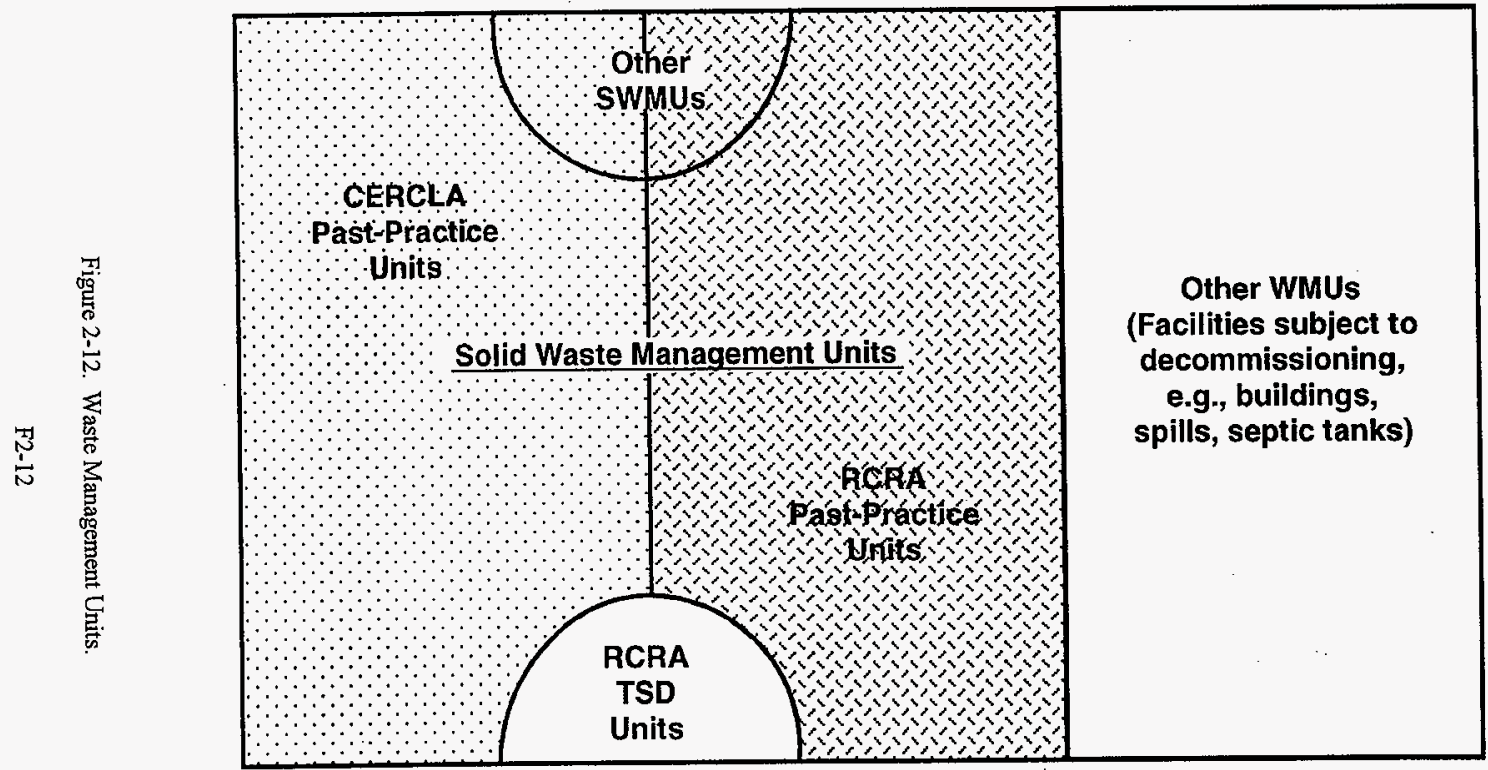

(not to scale)

CERCLA = Comprehenslve Environmental Response, Compensation, and Llabllity Act.

RCRA = Resource Conservation and Recovery Act.

TSD = treatment, storage, and /or disposal units either operating, undergoing closure, or being dispositioned through other options.

WMU = waste management unit. 
3.1 CHEMICAL, BIOLOGICAL, AND PHYSICAL ANALYSIS $[C-1] \ldots \ldots \ldots \ldots \ldots \ldots . .1$

3.1 .1 Land Disposal Restrictions $\ldots \ldots \ldots \ldots \ldots \ldots \ldots \ldots \ldots \ldots \ldots \ldots \ldots \ldots, 3-1$

3.1 .2 Organic Air Emissions $\ldots \ldots \ldots \ldots \ldots \ldots \ldots \ldots \ldots \ldots \ldots \ldots \ldots \ldots \ldots \ldots \ldots, 3-2$

3.1.3 Waste in Piles $[\mathrm{C}-1 \mathrm{a}] \ldots \ldots \ldots \ldots \ldots \ldots \ldots \ldots \ldots \ldots \ldots \ldots \ldots \ldots \ldots \ldots \ldots, 3.2$

3.1.4 Landfilled Wastes $[\mathrm{C}-1 \mathrm{~b}] \ldots \ldots \ldots \ldots \ldots \ldots \ldots \ldots \ldots \ldots \ldots \ldots \ldots \ldots \ldots \ldots \ldots \ldots \ldots \ldots \ldots \ldots, 3$

3.1.5 Wastes Incinerated and Wastes Used in Performance Tests $[\mathrm{C}-1 \mathrm{c}] \ldots \ldots \ldots \ldots$. $\ldots .3$

3.2 WASTE ANALYSIS PLAN $[\mathrm{C}-2] \ldots \ldots \ldots \ldots \ldots \ldots \ldots \ldots \ldots \ldots \ldots \ldots \ldots \ldots \ldots \ldots, 3$

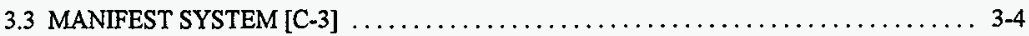

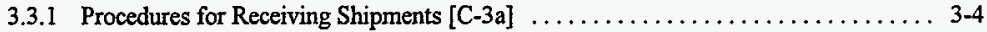

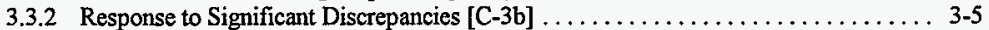

3.3.3 Provisions for Non-acceptance of Shipment $[C-3 c] \ldots \ldots \ldots \ldots \ldots \ldots \ldots \ldots, 3-5$

3.3.3.1 Non-acceptance of Undamaged Shipment $[C-3 c(1)] \ldots \ldots \ldots \ldots \ldots \ldots, 3-5$

3.3.3.2 Activation of Contingency Plan for Damaged Shipment $[C-3 c(2) \ldots \ldots \ldots, 3-5$

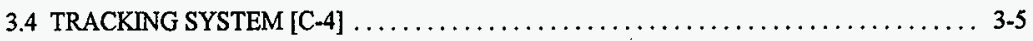

3.5 OTHER WASTE ANALYSIS DOCUMENTATION $\ldots \ldots \ldots \ldots \ldots \ldots \ldots \ldots \ldots, 3-6$

3.5.1 Sampling and Analysis Plan $\ldots \ldots \ldots \ldots \ldots \ldots \ldots \ldots \ldots \ldots \ldots \ldots \ldots, 3-6$

3.5.2 Data Evaluation Report .................................... 3-6 
DOE/RL-91-28, Rev, 4

05/98

1

2

3

4

5

This page intentionally left blank. 


\subsection{WASTE ANALYSIS [C]}

This chapter provides general information, specified in Section C of Ecology's permit application guidance (Ecology 1987 and 1996), on the analysis and handling of waste treated, stored, and/or disposed on the Hanford Facility. Topics discussed include the following:

- Chemical, biological, and physical analyses

- Waste analysis plan

- Manifest system

- Tracking system

- Other waste analysis documentation.

Provisions contained in Conditions I.E. (Duties and Requirements), II.A. (Facility Contingency Plan), II.D. (Waste Analysis), II.E. (Quality Assurance/Quality Control), II.N. (Receipt of Dangerous Wastes Generated Offsite), II.P. (Manifest System), and II.Q. (On-Site Transportation) of the HF RCRA Permit (DW Portion) also are discussed.

Detailed information on the characteristics of the waste treated, stored, and/or disposed at individual 'operating' TSD units is contained in the Unit-Specific Portion of this permit application. Detailed information on waste treated, stored, and/or disposed at individual TSD units 'undergoing closure' or being 'dispositioned through other options' has been, or is anticipated to be, submitted in accordance with the provisions of the Tri-Party Agreement.

\subsection{CHEMICAL, BIOLOGICAL, AND PHYSICAL ANALYSIS [C-1]}

The Hanford Facility treats, stores, and/or disposes of dangerous and/or mixed waste designated as: (1) characteristic dangerous waste (ignitable, corrosive, toxic, reactive); (2) toxic and persistent (by WAC 173-303 criteria); and (3) listed (e.g., due to the presence of spent solvents and discarded pure chemical products). The waste form ranges from liquid to hard crystalline material (e.g., salt cake stored in the DST System), as well as contaminated equipment, paper, rags, etc. A general overview of waste characteristics and process information for each 'operating' TSD unit (as of May 1, 1998) is contained in Chapter 4.0. Such an overview for TSD units 'undergoing closure' or being 'dispositioned through other options' is found in Chapter 2.0, Section 2.5).

Specific information on the type (i.e., DW numbers) and volume of waste that could be managed by each TSD unit is contained in the HF Part A. Part A permit application information is based primarily on process information with additional information provided by waste sampling and analysis programs.

\subsubsection{Land Disposal Restrictions}

Dangerous waste and the dangerous waste component of mixed waste on the Hanford Facility are subject to LDR requirements contained in 40 CFR 268, WAC 173-303-140, Condition II.G of the HF RCRA Permit (HSWA Portion), and in Section 6.1 and Milestone M-26-00 of the Tri-Party Agreement Action Plan. Under the regulations, waste is prohibited from land disposal unless the waste meets treatment standards specified in 40 CFR 268, Subpart D or meets requirements for a treatability variance. In addition, certain 
hazardous debris that have been contaminated with a listed hazardous waste may be excluded if managed pursuant to 40 CFR 261.3(f) and WAC 173-303-070(2)(c). Other environmental media, such as soils contaminated with listed waste, may be excluded from regulation if a determination is made by Ecology that the soil no longer contains a hazardous waste (i.e., contained-in determination).

The specified technologies for treatment of LDR waste are identified in the regulations for some waste in lieu of meeting a specific concentration requirement. While treatment capability generally exists for the dangerous waste subject to LDR, treatment currently is not available for the mixed waste subject to LDR that requires storage on the Hanford Facility. Provisions in the Tri-Party Agreement and in the Federal Facility Compliance Act of 1992 (refer to Chapter 13.0, Section 13.1.1.2) allow for storage of land disposal restricted waste until treatment and disposal capability is available. A brief summary of LDR provisions, described in Section 6.1 of the Tri-Party Agreement Action Plan, follows.

In fulfillment of Section 6.1 and Milestone M-26-00 of the Tri-Party Agreement Action Plan, the DOE-RL submitted to Ecology and the EPA in October 1990 the Hanford Land Disposal Restrictions Plan for Mixed Wastes (LDR Plan) (DOE/RL-90-41). This plan described a process for managing mixed waste subject to $L D R$ and identified actions to be taken by the DOE-RL to achieve full compliance with LDR requirements. These actions are to be in accordance with approved schedules specified in the LDR Plan and in the work schedule found in Appendix D of the Tri-Party Agreement Action Plan. The DOE-RL submits . annual reports (e.g., DOE/RL-95-15) updating the LDR Plan and any prior annual reports, including plans and schedules (refer to Chapter 12.0, Section 12.1.39). The annual report also describes activities taken to achieve compliance and describes the activities to be taken in the next year toward achieving full compliance.

Should it become necessary to seek an exemption from a disposal prohibition pursuant to 40 CFR 268.6; an extension to the effective date of any land disposal restriction pursuant to 40 CFR 268.5; a variance from a treatment standard pursuant to 40 CFR 268.44; an equivalent technology pursuant to 40 CFR 268.42(c); and/or an exemption pursuant to WAC 173-303-140(6), the records documenting the quantities and date each waste was placed under such exemption, extension, or variance will be maintained as required by 40 CFR 264.73(10).

The TSD units will follow the provisions of their waste analysis plans (refer to Section 3.2) to determine which, if any, LDR apply to their waste. Waste analysis plan provisions for 'operating' TSD units are found in the Unit-Specific Portion of this permit application.

\subsubsection{Organic Air Emissions}

Organic air emissions from the Hanford Facility are required to be addressed under the dangerous waste regulations (WAC 173-303-690 and -691) and RCRA (40 CFR 264 Subpart AA, BB, and CC). Information pertaining to these requirements is included in Chapter 4.0, Section 4.10.

\subsubsection{Waste in Piles [C-1a]}

Waste piles and containment buildings associated with TSD units 'undergoing closure' and with units being 'dispositioned through other options' are shown in Chapter 1.0, Table 1-1. 


\subsubsection{Landfilled Wastes [C-1b]}

Currently only one 'operating' TSD unit, the LLBG, is classified as a landfill. Information for this unit, currently operating under interim status, is found in the HF Part A, in Chapter 4.0 of the General Information Portion (refer to Section 4.1.2.8), and in the Unit-Specific Portion (DOE/RL-88-20). Landfills associated with TSD units 'undergoing closure' and with units being 'dispositioned through other options' are shown in Chapter 1.0, Table 1-1, and briefly described in Chapter 2.0, Section 2.5, and in Chapter 4.0, Section 4.1.2.8.

\subsubsection{Wastes Incinerated and Wastes Used in Performance Tests [C-1c]}

No incinerator units currently are found on the Hanford Facility. If incinerator units are established in the future, and if waste is used in performance tests, information for each unit will be entered into the HF Part $A$ and into the Unit-Specific Portion of this permit application.

\subsection{WASTE ANALYSIS PLAN [C-2]}

This section contains a discussion of waste analysis plans and related quality assurance information. The TSD units incorporated into Part III of the HF RCRA Permit (DW Portion) will address waste analysis and quality assurance in accordance with Conditions II.D. and II.E. of the HF RCRA Permit (DW Portion), respectively, and/or in accordance with any unit-specific conditions.

The WAC 173-303-300 requires a facility owner or operator to confirm the knowledge about a dangerous waste before this waste is treated, stored, and/or disposed. The purpose for such knowledge is to ensure that this dangerous waste is managed properly. Waste analysis plans contained in the Unit-Specific Portion of this permit application address the requirements of WAC 173-303-300(5). For TSD units that receive waste from offsite sources, the waste analysis plan includes measures for confirming that each dangerous waste received matches the identity of the waste specified on the accompanying manifest or shipping paper in accordance with WAC 173-303-300(5)(g).

Development and/or revision of TSD unit-specific waste analysis plans generally are carried out using guidance provided by the EPA (EPA/PB94-963-603). The data quality objective (DQO) process developed by the EPA (EPA/600/R-96/055) is a key tool in determining the type, quantity, and quality of data needed to support waste analysis. For Hanford Facility TSD units, DQOs are developed jointly between unit-specific representatives and the regulators in DQO workshops. The DQOs identify data needed for proper waste handling and treatment along with any data needed to ensure protection of the environment. After identification of the data reeded, the appropriate parameters, sampling and analytical methods, and quality assurance levels are selected. Where possible, sampling and analytical methods will be conducted in accordance with SW-846 (EPA/230/02-89-042) or WAC 173-303-110. However, because of the radioactive nature of the mixed waste, sampling and analytical methods could be modified, from those published by EPA and Ecology, to accommodate the special handling needs of mixed waste samples; the intent of EPA's and Ecology's methodologies will be attained where feasible and appropriate.

As noted in Condition II.E.5. of the HF RCRA Permit (DW Portion), the DQO process can be used to determine the level of quality assurance and quality control for the collection, preservation, transportation, and analysis of each sample that is required for the implementation of the HF RCRA Permit. The DQOs are 
1 approved by Ecology, in writing, or through incorporation of the TSD unit waste analysis plans into Part III 2 of the HF RCRA Permit (DW Portion).

Additional information on the quality assurance and quality control for individual TSD units can be found in the Unit-Specific Portion of this permit application. The information is integrated, as appropriate, with the quality assurance and control program discussed in Article XXXI of the Tri-Party Agreement and Sections 6.5 and 7.8 and Appendix F of the Tri-Party Agreement Action Plan. The Tri-Party Agreement reiterates the commitment to the $\mathrm{DQO}$ process as a means of specifying the appropriate levels of quality assurance and quality control.

Specific activities for each 'operating' TSD unit are governed by procedures. In accordance with WAC 173-303-806, a description of procedures pertinent to dangerous waste management activities could be incorporated into the HF RCRA Permit (DW Portion) (e.g., Attachment 10 of the DW Portion pertaining to the 616 NRDWSF).

Conditions II.F. and II.K. of the HF RCRA Permit (DW Portion) address groundwater monitoring and closure performance standards, respectively. Of particular relevance to the quality assurance and quality control of these activities are environmental investigation instructions. The environmental investigation instructions applicable to each 'operating' TSD unit are briefly described in the Unit-Specific Portion of this permit application. Current copies of these instructions are maintained on file and can be located by accessing the 'Records Contacts' identified in Chapter 12.0, Section 12.1.

\subsection{MANIFEST SYSTEM [C-3]}

The Hanford Facility manages dangerous and/or mixed waste from both onsite and offsite sources. Management of waste received from, or sent to, offsite sources is addressed in this section; managing of waste from onsite sources is addressed in Section 3.4.

Offsite shipments of dangerous and/or mixed waste to and from the Hanford Facility are subject to the manifest system requirements specified in WAC 173-303-370 and -180, respectively. The TSD units incorporated into Part III or Part V of the HF RCRA Permit (DW Portion) will address manifest system requirements in accordance with Conditions I.E.17., I.E.18., II.N., and II.P. of the HF RCRA Permit (DW Portion) and/or in accordance with any unit-specific conditions.

Additional manifest system information specific to individual TSD units can be found in the Unit-Specific Portion of this permit application. Manifest system records for TSD units incorporated into Part III or Part V of the HF RCRA Permit (DW Portion) are maintained on file (refer to Chapter 12.0, Section 12.1) and can be located by accessing the 'Records Contacts' identified in Chapter 12.0, Section 12.1.

\subsubsection{Procedures for Receiving Shipments [C-3a]}

The Hanford Facility receives dangerous and mixed waste from offsite (including foreign) sources. Such waste is subject to the manifest system requirements specified in WAC 173-303-370 and to the reporting requirements specified in WAC 173-303-390(1) and WAC 173-303-390(2). The TSD units 
incorporated into Part III of the HF RCRA Permit (DW Portion) will receive offsite waste in accordance with

Condition II.N. of the HF RCRA Permit (DW Portion) and/or in accordance with any unit-specific conditions.

Notification for foreign waste receipt is made in accordance with WAC 173-303-290. Notification of subsequent shipments of the same waste from the same foreign source in the same calendar year is not required.

\subsubsection{Response to Significant Discrepancies [C-3b]}

Appendix 2B contains a definition of 'Significant Discrepancy' taken from the HF RCRA Permit (DW Portion). The TSD units incorporated into Part III of the HF RCRA Permit (DW Portion) will respond to significant discrepancies in accordance with WAC 173-303-370(4) and WAC 173-303-390(1), Conditions I.E.17. and I.E.18. of the HF RCRA Permit (DW Portion), and/or in accordance with any unit-specific conditions.

\subsubsection{Provisions for Non-acceptance of Shipment [C-3c]}

This section addresses non-acceptance of undamaged shipments and activation of the contingency plan for damaged shipments.

3.3.3.1 Non-acceptance of Undamaged Shipment [C-3c(1)]. Provisions for non-acceptance of shipments are contained in WAC 173-303-370(5). The TSD units incorporated into Part III of the HF RCRA Permit (DW Portion) will address these provisions in accordance with WAC 173-303-370(5) and WAC 173-303390(1), Conditions I.E.17., I.E. 18., and II.P.1. of the HF RCRA Permit (DW Portion), and/or in accordance with any unit-specific conditions. Additional discussion of waste acceptance criteria for 'operating' TSD units is contained in the Unit-Specific Portion of this permit application.

\subsubsection{Activation of Contingency Plan for Damaged Shipment [C-3c(2). Attachment 4 of the} HF RCRA Permit (DW Portion) contains the Hanford Emergency Response Plan (DOE/RL-94-02). As specified in Condition II.A. and Attachment 3 of the HF RCRA Permit (DW Portion), this Plan applies to areas of the Hanford Facility between TSD unit boundaries to the extent of hazardous substance releases that threaten human health or the environment Furthermore, the hazardous substance releases are limited to transportation events occurring on the Hanford Facility.

TSD units incorporated into Part III of the HF RCRA Permit (DW Portion) will address damaged shipment response in accordance with the contingency plan developed for each TSD unit.

\subsection{TRACKING SYSTEM [C-4]}

The Hanford Facility has one EPA/State identification number and is considered to be a single RCRA facility. The boundaries of the Hanford Facility, as defined in Attachment 2 of the HF RCRA Permit (DW Portion), are shown in Chapter 2.0, Figure 2-1; roadways on the Hanford Facility are shown in Chapter 2.0, Figure 2-11. With the exception of conditions specified in Condition II.P.2 of the HF RCRA Permit (DW Portion), transportation along these roadways is considered to be onsite. Condition II.P.2. of the HF RCRA Permit (DW Portion) defines transportation of dangerous waste along State Highways 240, 24, 
and 243, and Route 4 South (Stevens Drive) (Chapter 2.0, Figure 2-11) to be offsite shipments requiring manifesting, unless such routes are closed to general public access at the time of the shipment.

Onsite transfers of dangerous or mixed waste are not subject to the manifesting requirements specified in WAC 173-303-370 and -180. However, all onsite waste transfers are conducted in a manner to ensure protection of human health and the environment. Waste tracking forms for the transfer of waste onsite are used. These waste tracking forms effectively track waste inventories from generation through treatment, storage, and/or disposal.

The TSD units incorporated into Part III of the HF RCRA Permit (DW Portion) will address onsite transportation in accordance with Conditions II.Q. of the HF RCRA Permit (DW Portion) and/or in accordance with any unit-specific conditions. Condition II.Q. of the HF RCRA Permit (DW Portion) specifies that documentation must accompany any onsite dangerous waste that is transported to or from any TSD unit subject to the HF RCRA Permit through or within the 600 Area (Chapter 2.0, Figure 2-11), unless the roadway is closed to general public access at the time of shipment. Waste transported by rail or by pipeline is exempt from Condition II.Q. of the HF RCRA Permit (DW Portion). Onsite waste tracking records for TSD units incorporated into Part III of the HF RCRA Permit (DW Portion) are maintained on file and can be located by accessing the 'Records Contacts' identified in Chapter 12.0, Section 12.1.

\subsection{OTHER WASTE ANALYSIS DOCUMENTATION}

Part of the activities associated with closure implementation for a TSD unit is to perform a DQO . process (refer to Section 3.2 and Chapter 11.0, Section 11.1.2). This process assists in determining the data needs for closure. The results of the DQO process are documented in a signed $D Q O$ agreement or in a sampling and analysis plan (SAP). Sampling and analysis activities are carried out in accordance with the SAP. Once the sampling activities are completed, and the analytical data validated, a report is prepared that evaluates the data. The report contains a recommendation on whether or not clean closure can be achieved. Condition II.D.1. of the HF RCRA Permit (DW Portion) addresses the need for a SAP for TSD units included in Part V.

\subsubsection{Sampling and Analysis Plan}

A SAP is prepared to document the DQO strategy developed to support closure of a TSD unit. The SAP describes the type of media that will be sampled, i.e., soil, concrete, gravel, or asphalt. The sample locations, number of samples per location, and the constituents that will be analyzed for also are discussed. In addition, the procedures that will be used to take the samples and prepare the samples for shipment to the laboratory are identified. The types of analytical methods that will be used by the laboratory are listed. Various tables and figures are included in the plan that support discussions on where samples will be taken, what constituents will be analyzed, and the number of samples.

\subsubsection{Data Evaluation Report}

A data evaluation report is prepared once the data have been analyzed and the results have been validated. This report discusses the sampling activities undertaken and the analytical results from the media sampled to support the closure of a TSD unit. The sample collection methods and field quality assurance and 
1 control methods are reviewed. Any field deviations from the SAP that occurred are documented in the report.

2 The previously agreed upon closure performance standards or cleanup levels are identified. Results of the

3 data validation for each sample analyte are discussed. The analytical data are evaluated and organized into

4 categories; for example, organics, metals, and/or anions. Finally, a conclusion section is prepared that states

5 the results of comparing the analytical data with the closure performance standards or cleanup levels. This

6 comparison serves as the basis for a decision on whether or not clean closure can be achieved. Various tables

7 also are included that contain information on the analytical results for each sample, data validation qualifiers

8 for each sample, and a comparison of the data for each sample to the associated closure performance

9 standards or cleanup levels. 
DOE/RL-91-28, Rev, 4

05/98

This page intentionally left blank. 


\section{CONTENTS}

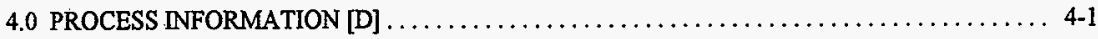

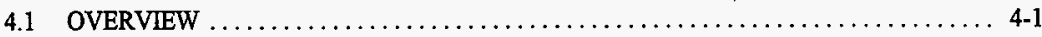

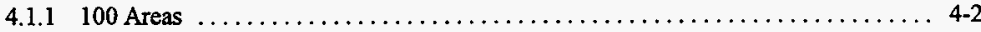

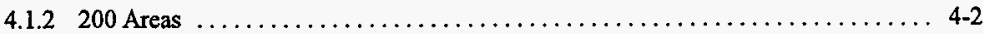

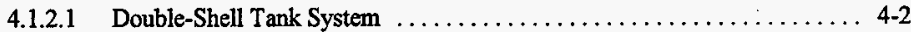

4.1.2.2 204-AR Waste Unloading Station ..................... 4-2

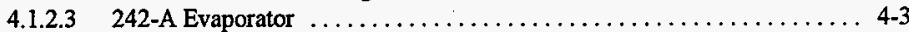

4.1.2.4 Liquid Effluent Retention Facility ................... 4-3

4.1.2.5 200 Area Effluent Treatment Facility .................. 4-3

4.1.2.6 Central Waste Complex .......................... 4-4

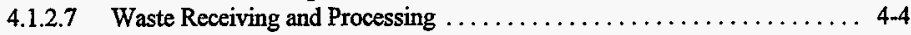

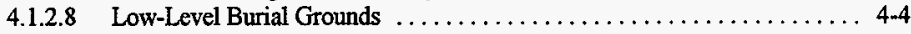

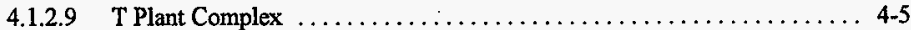

4.1.2.10 PUREX Storage Tunnels ............................ 4 .5

4.1.2.11 222-S Laboratory Complex ....................... 4-5

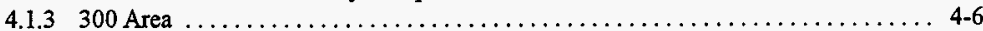

4.1.3.1 325 Hazardous Waste Treatment Units ................. 4-6

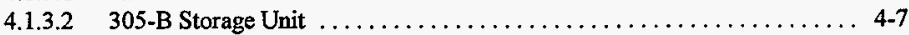

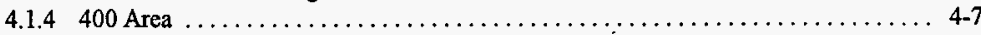

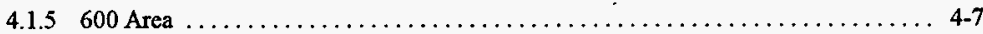

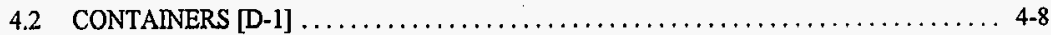

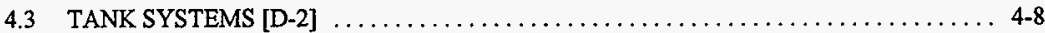

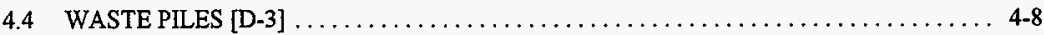

4.5 SURFACE IMPOUNDMENTS $[\mathrm{D}-4] \ldots \ldots \ldots \ldots \ldots \ldots \ldots \ldots \ldots \ldots \ldots \ldots \ldots$

4.6 INCINERATORS $[\mathrm{D}-5] \ldots \ldots \ldots \ldots \ldots \ldots \ldots \ldots \ldots \ldots \ldots \ldots \ldots \ldots \ldots \ldots \ldots \ldots \ldots \ldots$

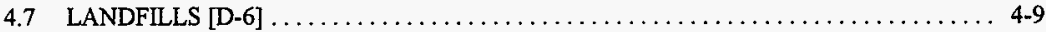

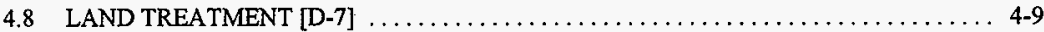

4.9 MISCELLANEOUS UNITS $\ldots \ldots \ldots \ldots \ldots \ldots \ldots \ldots \ldots \ldots \ldots \ldots \ldots \ldots \ldots \ldots$

4.10 AIR EMISSIONS CONTROL $[\mathrm{D}-8] \ldots \ldots \ldots \ldots \ldots \ldots \ldots \ldots \ldots \ldots \ldots \ldots \ldots \ldots \ldots$

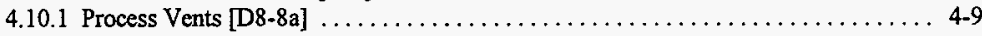

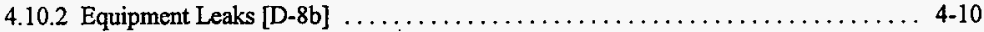

4.10.3 Tanks, Containers, and Surface Impoundments $[\mathrm{D}-8 \mathrm{c}] \ldots \ldots \ldots \ldots \ldots \ldots \ldots \ldots$ 4-10

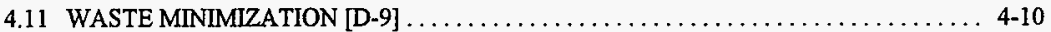


4.12 GROUNDWATER MONITORNG FOR LAND-BASED UNITS $[\mathrm{D}-10] \ldots \ldots \ldots \ldots, 4-10$

4.13 DESIGN AND OPERATIONAL INFORMATION $\ldots \ldots \ldots \ldots \ldots \ldots \ldots \ldots \ldots \ldots, 4-10$

4.13.1 Transmittal of Design Information to Regulatory Agencies $\ldots \ldots \ldots \ldots \ldots \ldots \ldots$ 4-10

4.13.2 Utilization of Aperture Cards ............................... 4-12

4.13.3 Replacement or Upgrading With Functionally Equivalent Components . . . . . . . . 4-12

4.13.4 Professional Engineer Certification ............................... 4-13

4.13.5 Mapping and Marking of Underground Pipelines ................... 4-13 


\subsection{PROCESS INFORMATION [D]}

This chapter provides general process information on the management of dangerous waste and mixed waste for Hanford Facility TSD units and addresses the provisions identified in Section D of Ecology's permit application guidance (Ecology 1987 and 1996). Also addressed are provisions contained in Conditions II.L., II.R., II.U., and II.V. of the HF RCRA Permit (DW Portion).

A brief description of process information for 'operating' TSD units is provided. A brief description of process information for TSD units 'undergoing closure' and for units being 'dispositioned through other options' is found in Chapter 2.0, Section 2.5 .

Also included is a discussion of the processes used to control design and operational information, and the method for transmitting design and operational changes to the regulators. In addition, a discussion of certification is included, as it pertains to supporting certain RCRA and dangerous waste permitting activities. Furthermore, mapping and marking activities conducted to meet HF RCRA Permit (DW Portion) requirements are summarized.

Activities conducted on the Hanford Facility that involve only the management of radioactive waste are not considered by the DOE-RL to be regulated under the RCRA or WAC 173-303 and, therefore, are not fully addressed in this chapter (refer to Chapter 2.0, Section 2.1.1.3.1). References to such activities are included for informational purposes only.

\subsection{OVERVIEW}

The Hanford Facility treats, stores, and/or disposes of dangerous and mixed waste generated on the Hanford Facility. Mixed waste generated offsite also is managed within certain TSD units. The Hanford Facility 'operating' TSD units are located in the 200,300,400, and 600 Areas (refer to Chapter 1.0, Table 1-1 and Appendix 2A). These TSD units are described briefly, by area, in the remainder of this section. For each of the 'operating' TSD units, the following information is provided: the classification of the TSD unit (e.g., surface impoundment, container storage unit, etc.); the type of waste processed at the TSD unit (dangerous and/or mixed waste); and a brief description of the waste management process or processes conducted at the TSD unit. Information presented in this chapter has been compiled from existing documents with the primary sources of information as follows: the HF Part A, the Tri-Party Agreement, the Hanford Mission Plan (DOE/RL-93-102), and the Hanford Site Environmental Permitting Status Report (DOE/RL-96-63).

More detailed process information for 'operating' TSD units is presented in the HF Part A, Form 3s (refer to Chapter 1.0). These Form $3 \mathrm{~s}$ contain an identification of specific dangerous waste numbers, process design capacities, and estimated annual quantities of waste handled.

Management of 'operating' TSD units is conducted in accordance with the current Hanford Missions (refer to Chapter 2.0, Section 2.1.1.4): to safely clean up and manage the legacy waste on the Hanford Site, and to develop and deploy science and technology (DOE/RL-96-92). To facilitate achievement of the Hanford Mission, work generally is organized into one of the following projects: 
- Tank Waste Remediation System

- Waste Management

- Facility Transition

- Environmental Restoration

- Science and Technology.

The relationship of 'operating' TSD units to the Hanford Mission and to onsite projects also is described. All TSD units discussed, except where noted, will operate under interim status until incorporated into the HF RCRA Permit (DW Portion) in accordance with the Class 3 Permit Modification Schedule (refer to Chapter 2.0, Section 2.1.1.3.3).

\subsubsection{Areas}

The 100 Areas contain no 'operating' TSD units.

\subsubsection{Areas}

The 200 East and 200 West Areas encompass the chemical separations plants used for the reprocessing of nuclear materials. These reprocessing plants generated various dangerous and mixed waste that was discharged to the soil column or stored in underground storage tanks (referred to as tank farms). The original mission for the plants in the 200 Areas was in support of nuclear weapons development and production related to national defense. The end of the Cold War prompted the shutdown of chemical separations activities supporting this original mission.

Most of the 'operating' TSD units are located in the 200 East and/or 200 West Areas (refer to Chapter 2.0, Figure 2-1 and Appendix 2A). A brief description of the 'operating' TSD units located in the 200 Areas is provided in the following sections.

4.1.2.1 Double-Shell Tank System. Mixed waste is managed in the DST System, a tank treatment and storage unit located in the 200 Areas. The DST System includes 28 tanks of approximately $4,000,000$ liter capacity, six smaller tanks in concrete vaults, ancillary equipment such as diversion boxes and waste transfer pipelines, and the 204-AR Waste Unloading Station (204-AR) (refer to Section 4.1.2.2). The DST System waste is treated by the addition of chemicals to control corrosion, by mixing using equipment such as airlift circulators or pumps, and could be treated by evaporation in four of the aging waste tanks (Appendix 2B). However, there are no future plans to perform evaporation in these tanks. The waste eventually will be retrieved, treated as necessary, and disposed (DOE/RL-93-102; Tri-Party Agreement).

The DST System currently is managed under the Tank Waste Remediation System Project. Part B documentation for the DST System is contained in the Unit-Specific Portion of this permit application (DOE/RL-90-39).

4.1.2.2 204-AR Waste Unloading Station. The 204-AR is a miscellaneous treatment unit located in the 200 East Area. This unit is used for the unloading and treatment of liquid mixed waste received from railroad tank cars and tanker trucks. The waste is generated from a variety of activities conducted in the 100,200 , 300 , and 400 Areas. During unloading operations, the $\mathrm{pH}$ of the waste can be adjusted chemically in-line during pumpout to meet the corrosion protection requirements of the DST System. 
The 204-AR currently is managed under the Tank Waste Remediation System Project. The 204-AR will be addressed in Part B permit application documentation for the DST System (DOE/RL-90-39).

4.1.2.3 242-A Evaporator. The 242-A Evaporator is a tank treatment and storage unit located in the 200 East Area. The 242-A Evaporator consists of process vessels and support systems for heating, evaporating, and condensing waste stored in the DST System. Thus, processing of waste through the 242-A Evaporator enables additional tank volume to become available to support such site activities as surplus facility decontamination, waste retrieval from DST and SST tanks, and waste vitrification. The 242-A Evaporator receives a mixed waste stream from the DST System that contains radionuclides, inorganic, and trace organic constituents. Treatment of the waste at the 242-A Evaporator results in two mixed waste streams. One mixed waste stream (slurry) contains the majority of the radionuclides and inorganic constituents and the nonvolatile organics. The other mixed waste stream (process condensate) contains greatly reduced concentrations of radionuclides and volatile organics. The slurry is routed back to the DST System for storage pending further treatment. The process condensate is routed to the Liquid Effluent Retention Facility (LERF) (refer to Section 4.1.2.4) for storage and treatment until transferred to the 200 Area ETF (refer to Section 4.1.2.5) for final treatment.

The 242-A Evaporator currently is managed under the Waste Management Project (200 Area Liquid Waste Processing Project). The 242-A Evaporator (based on documentation contained in DOE/RL-90-42) was incorporated into the HF RCRA Permit (DW Portion) and is currently operating under final status provisions contained in Chapter 5 of Part III of the HF RCRA Permit.

4.1.2.4 Liquid Effluent Retention Facility. The LERF, located in the 200 East Area, is classified as a surface impoundment. The LERF provides treatment and storage of 242-A Evaporator process condensate and dilute aqueous waste streams from other onsite waste management and remediation activities. Treatment is performed by flow and $\mathrm{pH}$ equalization of the waste to improve 200 Area ETF performance. The wastewater is stored and treated until transferred to the 200 Area ETF for treatment. The LERF is a retention facility consisting of three basins (surface impoundments). Each basin is constructed with two liners, a leachate collection system between the liners, and a floating cover.

The LERF currently is managed under the Waste Management Project (200 Area Liquid Waste Processing Project). The LERF (based on documentation contained in DOE/RL-97-03) was incorporated into the HF RCRA Permit (DW Portion) and is currently operating under final status provisions contained in Chapter 4 of Part III of the HF RCRA Permit.

\subsubsection{200 Area Effluent Treatment Facility. The 200 Area ETF is a tank treatment and storage and container storage unit located in the 200 East Area. This TSD unit treats and stores 242-A Evaporator process condensate and dilute aqueous waste streams from other onsite waste management and remediation activities. The 200 Area ETF contains a series of systems to reduce the concentration of organic, inorganic, and radioactive constituents (except tritium).}

The 200 Area ETF process involves two treatment trains. The waste water enters the primary treatment train where the inorganic and radioactive constituents are removed, and organic constituents are destroyed. The components of the primary treatment train include, but are not limited to, filtration, $\mathrm{pH}$ adjustments, ultraviolet light oxidation, reverse osmosis, and ion exchange. Treated effluent is collected in tanks, sampled to verify that discharge requirements have been met, and discharged to an approved disposal site. Once the discharge requirements have been met, the treated effluent is considered delisted and is no longer managed as a dangerous waste (40 CFR 261, Appendix IX, Table 2). The solids that are removed 
from the waste. water enter the secondary treatment train where the solids are dried and packaged for storage and/or disposal.

The 200 Area ETF currently is managed under the Waste Management Project (200 Area Liquid Waste Processing Project). The 200 Area ETF (based on documentation contained in DOE/RL-97-03) was incorporated into the HF RCRA Permit (DW Portion) and is currently operating under final status provisions contained in Chapter 4 of Part III of the HF RCRA Permit.

4.1.2.6 Central Waste Complex. The CWC is located in the 200 West Area. This storage and treatment unit consists of multiple storage structures (e.g., storage modules, buildings, and storage pads). Treatment includes absorption and solidification of free liquids and the neutralization of corrosive materials. The CWC provides the capacity to store both onsite and offsite mixed waste, low-level waste, and transuranic waste. A phased construction schedule is used to accommodate any changes in the mixed waste, low-level waste, and transuranic waste production rate.

The CWC currently is managed under the Waste Management Project (Solid Waste Project). Part B documentation for the CWC is contained in the Unit-Specific Portion of this permit application (DOE/RL-91-17).

4.1.2.7 Waste Receiving and Processing Facility. The WRAP will treat and store mixed waste, low-level waste, and transuranic waste. This TSD unit, located in the 200 West Area directly north of the CWC, will have the capability to change the physical form of the radioactive and/or mixed waste through compaction (volume reduction), repackaging, stabilization, solidification of liquids, neutralization, etc. The treated transuranic waste eventually will be transported for disposal at the Waste Isolation Pilot Plant in New Mexico (when this plant becomes operational) or to another transuranic waste disposal site.

The WRAP currently is managed under the Waste Management Project (Solid Waste Project). Part B documentation for WRAP is contained in the Unit-Specific Portion of this permit application (DOE/RL-91-16).

4.1.2.8 Low-Level Burial Grounds. The LLBG are a land-based unit consisting of eight burial grounds located in the 200 East Area and 200 West Area. Seven of the eight burial grounds (218-E-12B, 218-E-10, 218-W-3A, 218-W-3AE, 218-W-4C, 218-W-5, and 218-W-6) are, or will be, used for the disposal of mixed waste and are subject to WAC 173-303. Current plans call for designating one of the burial grounds (218-W-4B), and portions of burial grounds 218-E-10, 218-E-12B, 218-W-3A, 218-W-3AE, 218-W-4C, and 218-W-5 as SWMUs (Appendix 2A). These areas received solid waste prior to enactment of HSWA as described in Chapter 2.0, Section 2.5.1. The SWMU portions of the LLBG will continue to accept for disposal low-level (radioactive) waste only.

The LLBG consist of both lined and unlined trenches of various sizes and depths. Mixed waste is disposed in lined trenches or in unlined trenches for which an exemption from the liner/leachate collection system requirements is sought. The unlined trenches that are not exempt from liner/leachate collection system requirements are used for radioactive waste disposal and are not subject to RCRA or WAC 173-303 regulations. Trenches $3 i$ and 34 of the $218-\mathrm{W}-5$ Burial Ground are currently being used for greater than 90-day container storage. At a future date these trenches will be managed in a disposal configuration. 
The LLBG currently is managed under the Waste Management Project (Solid Waste project). Part B documentation for the LLBG is contained in the Unit-Specific Portion of this permit application (DOE/RL-88-20).

4.1.2.9 T Plant Complex. The T Plant Complex consists of two main structures: the 221-T Building and the 2706-T Building and various support structures and storage units. The T Plant Complex provides storage (tank, container, and miscellaneous equipment) and treatment (tank, container, and decontamination activities) of mixed (radioactive and dangerous) waste before transfer to an onsite TSD unit or an offsite TSD facility. Types of waste processing at these buildings and various support structures or units could include characterization, verification, assay, sampling and analysis, repackaging, and various treatments. Waste equipment or useable equipment could be stored temporarily, and treatment or decontamination of equipment could be performed at various facilities at the T Plant Complex.

The tank systems housed in the 221-T building are used to manage mixed waste. The tank systems are used to store and treat waste generated by equipment decontamination activities and other treatment activities in the 221-T and 2706-T Buildings. The 2706- $\mathrm{T}$ Building waste is transferred to the 221-T Building via the 211-T collection sump. Alternatively, the 2706-T Building waste could be pumped directly to a railroad tank car or tanker truck. The liquid waste is pumped from the tanks to a railroad tank car or tanker truck and transferred to an onsite TSD unit or an offsite TSD Facility when a sufficient quantity is collected. The liquid mixed waste also could be transferred from storage tanks by underground pipelines to the DST System.

The T Plant Complex currently is managed under the Waste Management Project (Solid Waste Project). Part B documentation for the T Plant Complex is contained in the Unit-Specific Portion of this permit application (DOE/RL-95-36).

4.1.2.10 PUREX Storage Tunnels. The PUREX Facility, located in the 200 East Area, consists of two separate TSD units, the PUREX Plant (202-A Building) (refer to Chapter 2.0, Section 2.5.2.1.1) and the PUREX Storage Tunnels. The PUREX Storage Tunnels, a miscellaneous storage unit, are located next to the PUREX Plant in the 200 East Area. The PUREX Storage Tunnels include two underground railroad storage tunnels used for the long-term storage of material removed from the PUREX Plant and from other onsite activities. Tunnel number 1 provides storage space for eight railroad cars. Between June 1960 and January 1965, all eight railroad car positions were filled and the tunnel subsequently sealed. Tunnel Number 2 provides storage space for 40 railroad cars. The first railroad car was placed in Tunnel Number 2 in December 1967. Space for additional railroad cars is still available in Tunnel Number 2.

The PUREX Storage Tunnels currently are managed under the Facility Transition Project. The PUREX Storage Tunnels (based on documentation contained in DOE/RL-90-24) was incorporated into the HF RCRA Permit (DW Portion) and currently is operating under final status provisions contained in Chapter 3 of Part III of the HF RCRA Permit.

4.1.2.11 222-S Laboratory Complex. The 222-S Laboratory Complex has a tank storage treatment unit and container storage units located in the 200 West Area. The 222-S Laboratory Complex provides analytical support services for the Hanford Site and includes the storage and treatment of dangerous and/or mixed waste generated during analytical operations. The 222-S Laboratory Complex consists of three areas: the 219-S Waste Handling Facility, the 222-S Dangerous and Mixed Waste Storage Area, and Room 2-B Storage Area. 
The 219-S Waste Handling Facility is located northeast of the 222-S Analytical Laboratory building and consists of a primary storage/treatment tank and two backup storage tanks. The liquid mixed waste generated from the laboratory flows by gravity to the 219-S Waste Handling Facility tanks where the waste is treated to adjust the $\mathrm{pH}$ before transfer to the DST System.

The 222-S Dangerous and Mixed Waste Storage Area is located on the north side of the 222-S Analytical Laboratory building. The 222-S Dangerous and Mixed Waste Storage Area consists of two metal storage structures resting on a concrete pad. The 222-S Dangerous and Mixed Waste Storage Area provides storage for various sized containers or other packages and overpacks of mixed and/or dangerous waste.

A portion of Room 2-B, located within the 222-S Analytical Laboratory Building, provides for container storage of various sized containers or other packages and overpackages of mixed and/or dangerous waste.

The 222-S Laboratory Complex currently is managed under the Waste Management Project. Part B documentation for the 222-S Laboratory Complex is contained in the Unit-Specific Portion of this permit application (DOE/RL-91-27).

\subsubsection{Area}

The 300 Area historically was used for the fabrication of the 100 Areas reactor fuels and for the main $\mathrm{RD} \& \mathrm{D}$ activities. Fuel fabrication activities ceased when $\mathrm{N}$ Reactor was placed in standby and shutdown. Current activities include RD\&D supporting the waste management and environmental restoration and remediation mission, including the development of new technologies for the treatment and disposal of the waste accumulated throughout the life of the Hanford Site. A brief description of the two 'operating' TSD units located in the 300 Area follows.

4.1.3.1 325 Hazardous Waste Treatment Units. The 325 HWTUs are located in the 325 Building within the 300 Area. The 325 HWTUs consist of the following treatment and storage areas: Hazardous Waste Treatment Unit, Shielded Analytical Laboratory, and the 325 Collection/Loadout Station Tank.

The Hazardous Waste Treatment Unit is located in the northeast corner of the 325 Building. The Hazardous Waste Treatment Unit provides treatment and storage of mixed waste and/or dangerous waste in approved containers.

The Shielded Analytical Laboratory is located in the west side of the 325 Building. The Shielded Analytical Laboratory provides analytical chemistry services within six interconnected hot cells to prepare and analyze samples of mixed waste. The Shielded Analytical Laboratory also provides storage and treatment of mixed waste in approved containers and in the 325 Shielded Analytical Laboratory tank.

The 325 Collection/Loadout Station Tank (under design) will be located in the southeast comer of the basement of the 325 Building. The 325 Collection/ Loadout Station Tank will store and treat mixed waste from various laboratory activities throughout the 325 Building.

The 325 HWTUs currently are managed under the Science and Technology Project. The 325 HWTUs (based on documentation contained in DOE/RL-92-35) was incorporated into the HF RCRA Permit 
(DW Portion) and currently is operating under final status provisions contained in Chapter 6 of Part III of the 2 HF RCRA Permit.

3

4.1.3.2 305-B Storage Unit. The 305-B is a container storage unit in the 300 Area. This unit is used to receive, store, and prepare dangerous and mixed waste for shipment. Waste managed at the $305-\mathrm{B}$ is generated primarily in support of $R D \& D$ activities. Waste is characterized by the generating unit as required for designation and transported to the $305-\mathrm{B}$ by truck or light utility vehicle. On receipt at the $305-\mathrm{B}$, the waste is placed into the proper storage area depending on the waste type and quantity. When a sufficient quantity of waste has been accumulated, the waste is inspected for shipment, and transported to an onsite TSD unit (for mixed waste, e.g., CWC; refer to Section 4.1.2.6) or an offsite TSD facility (for dangerous waste).

The 305-B currently is managed under the Science and Technology Project. The 305-B (based on documentation contained in DOE/RL-90-01) was incorporated into the initial HF RCRA Permit (DW Portion) and is operating under final status provisions contained in Chapter 2 of Part III of the HF RCRA Permit (DW Portion).

\subsubsection{Area}

The 400 Area contains no 'operating' TSD units.

\subsubsection{Area}

The 600 Area includes everything within the Hanford Facility boundary that is not within any other specific area (Chapter 2.0, Figure 2-3). A brief description of the one 'operating' TSD unit located in the 600 Area follows.

The 616 NRDWSF is a container storage unit, located between the 200 East and 200 West Areas. The 616 NRDWSF provides a centralized unit to receive, store, and prepare nonradioactive dangerous waste for offsite shipment. Before receipt of dangerous waste at the TSD unit, the generating unit characterizes the waste, assigns waste numbers according to WAC 173-303, and packages the waste according to U.S. Department of Transportation regulations. The waste is transferred to the 616 NRDWSF by truck. Once a waste transfer is accepted from the transporter, an appropriate storage cell for each container is selected, depending on the dangerous waste designation. Periodically during the year, depending on the rate of waste accumulation, containers are remanifested, inspected for offsite shipment, and transported to an offsite TSD facility.

The 616 NRDWSF is currently managed under the Waste Management Project (Solid Waste Project). The 616 NRDWSF (based on documentation contained in DOE/RL-89-03) was incorporated into the initial HF RCRA Permit (DW Portion) and currently is operating under final status provisions contained in Chapter 1 of Part III of the HF RCRA Permit. 


\subsection{CONTAINERS [D-1]}

The Hanford Facility 'operating' TSD units with container handling capabilities (refer to Chapter 1.0, Table 1-1) include the following:

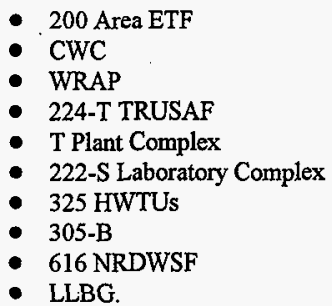

The T Plant Complex also includes a containment building.

\subsection{TANK SYSTEMS [D-2]}

The Hanford Facility 'operating' TSD units with tank systems (refer to Chapter 1.0, Table 1-1) include the following:

- DST System

- 242-A Evaporator

- 200 Area ETF

- T Plant Complex

- 222-S Laboratory Complex

- 325 HWTUs.

\subsection{WASTE PILES [D-3]}

No Hanford Facility 'operating' TSD units currently are classified as waste piles.

\subsection{SURFACE IMPOUNDMENTS [D-4]}

The LERF is the only Hanford Facility 'operating' TSD unit classified as a surface impoundment (refer to Chapter 1.0, Table 1-1).

\subsection{INCINERATORS [D-5] .}

No Hanford Facility 'operating' TSD units currently are classified as incinerators. 


\subsection{LANDFILLS [D-6]}

The LLBG are the only Hanford Facility 'operating' TSD unit classified as a landfill (Chapter 1.0, Table 1-1).

\subsection{LAND TREATMENT [D-7]}

No Hanford Facility 'operating' TSD units currently are classified as land treatment units.

\subsection{MISCELLANEOUS UNITS}

The PUREX Storage Tunnels are the only Hanford Facility 'operating' TSD unit classified as a miscellaneous unit (refer to Chapter 1.0, Table 1-1).

\subsection{AIR EMISSIONS CONTROL [D-8]}

Air emissions released from certain or applicable Hanford Facility TSD units are regulated under the dangerous waste regulations (WAC 173-303-690 and -691) and RCRA (40 CFR 264 Subpart AA, BB, and CC). The following sections discuss air emissions on the Hanford Facility.

\subsubsection{Process Vents [D8-8a]}

Hanford Facility process vents associated with specific separation processes identified in WAC 173-303-690(1)(6), which are used to manage hazardous waste with organic concentrations of at least 10 parts per million by weight, are regulated under WAC 173-303-690. Threshold limits that require emission controls apply to the summation of all applicable emission sources for the entire Hanford Facility.

To determine whether the threshold limits are exceeded, thereby requiring emission controls, the applicable processes were identified first for each TSD unit. Of the Hanford Facility TSD units, only the 242-A Evaporator and 200 Area ETF currently operate processes that contribute to the Hanford Facility organic emissions release rate.

Estimates for a 1995 242-A Evaporator campaign (Campaign 95-1) yielded a maximum emission rate of 0.316 kilogram per hour and a 212-kilogram total release (WHC-SD-WM-PE-056). Future plans are to operate an average of two campaigns per year with organic emissions similar to Campaign 95-1. Performance tests for volatile organic compound emissions at the 200 Area ETF were completed in January of 1996 . These tests yielded an average emission rate of 0.35 gram per minute measured at stream number G6 of the ventilation offgas system. When combined, the 242-A Evaporator and 200 Area E'TF emission rates total 0.337 kilogram per hour. This combined release rate is well below the threshold of 1.4 kilograms per hour or 2,800 kilograms per year.

In summary, the process vents on the Hanford Facility currently do not exceed the threshold limits triggering process controls under the regulations. However, the amount of organic emissions could change as waste streams are changed, or TSD units are brought online or are deactivated. The organic air emissions 
summation will be re-evaluated periodically as conditions warrant. Further details regarding process vents are discussed in the applicable Unit-Specific Portion of this permit application.

\subsubsection{Equipment Leaks [D-8b]}

The organic air emissions released from Hanford Facility equipment leaks are regulated under dangerous waste regulations WAC 173-303-691. These regulations apply to equipment that manages hazardous waste with organic concentrations of at least 10 percent by weight. Individual TSD units managing waste with organic concentrations of at least 10 percent by weight include special precautions and equipment to mitigate air emissions from leakage. Further details specific to individual TSD units can be found in the Unit-Specific Portion of this permit application:

\subsubsection{Tanks, Containers, and Surface Impoundments [D-8c]}

Certain organic air emissions released from Hanford Facility hazardous waste tanks, containers, and surface impoundments are regulated under 40 CFR 264, Subpart CC. These regulations apply to tanks, containers, and surface impoundments used to manage certain organic-containing hazardous waste. Mixed waste has been deferred from the regulations under Subpart CC. Therefore, only individual TSD units at the Hanford Facility that manage hazardous waste (not mixed waste) will address Subpart CC. Further details specific to individual TSD units can be found in the Unit-Specific Portion of this permit application.

\subsection{WASTE MINIMIZATION [D-9]}

Waste minimization information is presented in Chapter 10.0 .

\subsection{GROUNDWATER MONITORING FOR LAND-BASED UNITS [D-10]}

Groundwater monitoring for land-based units is presented in Chapter 5.0.

\subsection{DESIGN AND OPERATIONAL INFORMATION}

This section presents a discussion of the processes used to control design and operational information, and the method for transmitting design and operational changes to the regulators in accordance with the HF RCRA Permit (DW Portion). In addition, a discussion of certification is included, as it pertains to supporting certain RCRA and dangerous waste permitting activities. Furthermore, mapping and marking activities conducted to meet HF RCRA. Permit (DW Portion) requirements are summarized.

\subsubsection{Transmittal of Design Information to Regulatory Agencies}

Design of TSD units on the Hanford Facility is controlled in accordance with an established engineering control system. This system serves as the basis for meeting HF RCRA Permit (DW Portion) 
design information requirements. Standard engineering practices ensure that uniform methods are in place to control tasks such as design review, configuration control, change control, specification preparation, and review and approval requirements. These practices are used on all engineering, development, and project work on the Hanford Facility that result in a documented design or deliverable hardware end item.

Development of, and changes to, design specifications and drawings related to TSD units on the Hanford Facility are carried out in accordance with the engineering practices of the contractor responsible for the activity. Although there is some variation among contractors, no work affecting design (excluding emergency response activities that will be conducted in accordance with contingency plans) is allowed to be performed at a TSD unit until an approved design drawing or appropriate engineering design directive has been issued. This process ensures that components and materials selected meet system requirements while providing a means for configuration control.

Condition II.L. of the HF RCRA Permit (DW Portion) establishes general requirements for design and operation of TSD units incorporated into Part III of the HF RCRA Permit, particularly those related to 'critical systems'. 'Critical systems' are defined in the Definitions section of the HF RCRA Permit (DW Portion) as follows:

"The term Critical Systems as applied to determining whether a permit modification is required means those specific portions of a TSD unit's structure or equipment whose failure could lead to the release of dangerous waste into the environment and/or systems which include processes which treat, transfer, store or dispose of regulated wastes."

Critical systems will be defined as applicable, for each 'operating' TSD unit within the Unit-Specific Portion of this permit application.

Condition II.L.1. of the HF RCRA Permit (DW Portion) addresses the need for proper design, construction, maintenance, and operational controls to minimize the possibility of a fire, explosion, or any unplanned sudden or non-sudden release of hazardous substances that could threaten human health or the environment. Existing Hanford Site design standards (DOE Order 6430.1A) generally address these requirements and are factored into Hanford Facility design and construction activities.

Condition II.L. 2 of the HF RCRA Permit (DW Portion) establishes general requirements for design changes, nonconformance, and as-built drawings. Condition II.L.2.b. of the HF RCRA Permit (DW Portion) requires that during construction of a project subject to the HF RCRA Permit, changes to the approved design, plans, and specifications be documented with an engineering change notice. $(\mathrm{ECN})$. Condition II.L.2.b. of the HF RCRA Permit (DW Portion) further requires:

- All ECNs be maintained in the TSD unit-specific portion of the Hanford Facility Operating Record (refer to Chapter 12.0, Section 12.1.35) and be available to Ecology upon request or during the course of an inspection

- Copies of ECNs affecting any critical system be provided to Ecology within 5 working days of initiating the $\mathrm{ECN}$

- Ecology to review an ECN modifying a critical system and inform the Permittees within 2 working days in writing whether the proposed $\mathrm{ECN}$, when issued, will require a Class 1,2 , or 3 permit 
modification. If after 2 working days Ecology has not responded, it will be deemed as acceptance of the ECN by Ecology.

Condition II.L.2.c. of the HF RCRA Permit (DW Portion) requires that during construction of a project subject to the HF RCRA Permit, any work completed that does not meet or exceed the standards of the approved design, plans and specifications be documented with a nonconformance report (NCR). Condition II.L.2.c. of the HF RCRA Permit (DW Portion) further requires:

- All NCRs be maintained in the TSD unit-specific portion of the Hanford Facility Operating Record (refer to Chapter 12.0, Section 12.1.35) and be available to Ecology upon request or during the course of an inspection

- Copies of NCRs affecting any critical system be provided to Ecology within 5 working days after identification of the nonconformance

- Ecology to review an NCR affecting a critical system and inform the Permittees within 2 working days in writing whether a permit modification is required of any nonconformance and whether prior approval is required from Ecology before work proceeds that affects the nonconforming item. If after 2 working days Ecology has not responded, it will be deemed as acceptance and no permit modification is required.

Condition II.L.2.d. of the HF RCRA Permit (DW Portion) requires that upon completion of a construction project subject to the HF RCRA Permit, as-built drawings be prepared. These as-built drawings are to incorporate the design and construction modifications resulting from all project ECNs and NCRs as well as modifications made pursuant to WAC 173-303-830. Completed as-built drawings are to be placed within the TSD unit-specific portion of the Hanford Facility Operating Record (refer to Chapter 12.0, Section 12.1.36) within 12 months of completing construction, or within an altemate period of time specified in Part III of the HF RCRA Permit (DW Portion).

On an ongoing basis, a tabulation of design changes [for those TSD units incorporated into Part III of the HF RCRA Permit (DW Portion)] can be located by accessing the 'Records Contact' identified in Chapter 12.0, Section 12.1 .

\subsubsection{Utilization of Aperture Cards}

Design drawings included as part of unit-specific documentation normally will be provided in an 27.9-centimeter by 43.2-centimeter format. Drawings provided in this format, for the most part, will exhibit a sufficient degree of legibility to support document review. In selected cases, it could be necessary to enlarge certain portions of drawings to enhance legibility. To support this need, drawings included as part of unit-specific documentation also will be provided in an aperture card format.

\subsubsection{Replacement or Upgrading With Functionally Equivalent Components}

All maintenance on the Hanford Facility is controlled and performed in accordance with an established work control system. The work control system ensures that the proper documentation is prepared for the activity, and also provides a means to track work from initiation to completion. The work control system also 
addresses replacement or upgrading with functionally equivalent materials. This system serves as the basis for meeting HF RCRA Permit (DW Portion) equivalent component requirements.

Condition II.R of the HF RCRA Permit (DW Portion) establishes general requirements for the substitution of an equivalent or superior product for any equipment or materials specified in the HF RCRA Permit. Use of these products are not considered a permit modification. However, a substitution will not be considered equivalent unless it is at least as effective as the original equipment or materials in protecting human health and the environment.

Condition II.R of the HF RCRA Permit (DW Portion) also requires substitution documentation to be placed in the TSD unit-specific portion of the Hanford Facility Operating Record within 7 days after the change is put into effect. The substitution documentation is to be accompanied by a narrative explanation, and the date the substitution became effective. The location of substitution documentation for TSD units incorporated into Part III the HF RCRA Permit (DW Portion) can be determined by accessing the 'Records Contact' identified in Chapter 12.0, Section 12.1.

\subsubsection{Professional Engineer Certification}

Certifications in accordance with WAC 173-303-810(13)(a) by an independent qualified registered professional engineer/registered professional engineer are required to support certain RCRA and dangerous waste permitting activities on the Hanford Facility (e.g., tank integrity assessments, closures, etc.). Certifications will be performed in accordance with practices used by TSD facilities throughout the rest of Washington State. Multiple certifications by the same individual will not nullify the individual's independent status.

\subsubsection{Mapping and Marking of Underground Pipelines}

Conditions II.U. and II.V. of the HF RCRA Permit (DW Portion) specify requirements for the mapping and marking of underground pipelines, respectively. These conditions apply to dangerous waste underground pipelines, including active, inactive, and abandoned pipelines that contain or contained dangerous waste subject to the provisions of WAC 173-303. The requirements associated with these mapping and marking conditions were further clarified and refined through a value engineering study conducted in May 1995 (ICF KH ENG-W-95-2160).

Condition II.U. of the HF RCRA Permit (DW Portion) specifies a time-phased approach be taken for the mapping of underground pipelines, involving the following:

- Condition II.U.1. of the HF RCRA Permit (DW Portion) required the Permittees to complete a methodology report within 24 months of the effective date of the HF RCRA Permit (i.e., by September 27, 1996). This report (DOE/RL-96-50) describes the methods used to generate information required by Conditions II.U.2., II.U.3., and II.U.4. of the HF RCRA Permit (DW Portion).

- Condition II.U.2. of the HF RCRA Permit (DW Portion) required the Permittees to complete an initial submittal within 36 months of the effective date of the HF RCRA Permit (i.e., by September 29, 1997). The submittal consisted of maps showing the location of dangerous waste 
underground pipelines that are located outside of the fences enclosing the 200 East, 200 West, $300,400,100 \mathrm{~N}$, and $100 \mathrm{~K}$ Areas. The maps (aperture cards) showing the location of these pipelines were submitted to Ecology on September 29, 1997.

- Condition II.U.3. of the HF RCRA Permit (DW Portion) requires the Permittees to complete an initial submittal within 48 months of the effective date of the HF RCRA Permit (i.e., by September 28, 1998). This submittal is to consist of pipeline schematics for dangerous waste underground pipelines within the 200 East, 200 West, $300,400,100 \mathrm{~N}$, and $100 \mathrm{~K}$ Areas. Information that is to accompany these schematics also is specified in Condition II.U.3. of the HF RCRA Permit (DW Portion). These schematics are to be maintained in the Hanford Facility Operating Record (refer to Chapter 12.0, Section 12.1.40) and updated annually after the initial submittal. The results of the value engineering study (ICF KH ENG-W-95-2160) determined that the information required by Condition II.U.3. of the HF RCRA Permit (DW Portion) (i.e., pipeline attributes, pipeline status, and direction of flow) can be incorporated into the Condition II.U.4. of the HF RCRA Permit (DW Portion) submittal. Thus, the enhanced Condition II.U.4. of the HF RCRA Permit (DW Portion) submittal also will satisfy Condition II.U.3. of the HF RCRA Permit (DW Portion), as both are due within 48 months.

- Condition II.U.4. of the HF RCRA Permit (DW Portion) requires the Permittees to complete an initial submittal within 48 months of the effective date of the HF RCRA Permit (i.e., by September 28, 1998). This submittal is to consist of maps showing the location of dangerous waste underground pipelines within the 200 East, $200 \mathrm{West}, 300,400,100 \mathrm{~N}$, and $100 \mathrm{~K}$ Areas. Information that is to accompany these maps also is specified in Condition II.U.4. of the HF RCRA Permit (DW Portion). The methodology report (DOE/RL-96-50) submitted to satisfy Condition II.U.1 provides the methods used to present, qualify, archive, etc. the required information. These maps are to be maintained in the Hanford Facility Operating Record (refer to Chapter 12.0, Section 12.1.40) and updated annually after the initial submittal.

Condition II.V. of the HF RCRA Permit (DW Portion) specifies that within 36 months of the effective date of the HF RCRA Permit (DW Portion) (i.e., by September 29, 1997), the pipelines specified in Condition II.U.2. of the HF RCRA Permit (DW Portion) are to be marked. These pipelines are to be marked at the point the pipelines pass beneath a fence enclosing the 200 East, $200 \mathrm{West}, 300,400,100 \mathrm{~N}$, or $100 \mathrm{~K}$ Areas, at the origin and destination, at any point the pipelines cross an improved road, and every 100 meters along the pipeline corridor where practicable. The markers are to be labeled with a sign that reads "Buried Dangerous Waste Pipe" and visible from a distance of 15 meters. The value engineering study (ICF KH ENG-W-95-2160) concluded that equivalent worded signs, already in place, could be used to meet this condition. Ecology was notified on September 29, 1997 that Permit Condition II.V. was complete. 


\section{CONTENTS}

5.0 GROUNDWATER MONTTORING FOR LAND-BASED UNITS [D-10] $\ldots \ldots \ldots \ldots \ldots \ldots, 5-1$

5.1 EXEMPTION FROM GROUNDWATER PROTECTION REQUIREMENTS [D-10a] . . . . 5-3

5.2 INTERIM STATUS PERIOD GROUNDWATER MONITORING DATA [D-10b] . . . . 5-3

5.2.1 Interim Status Groundwater Monitoring Approach $\ldots \ldots \ldots \ldots \ldots \ldots \ldots \ldots \ldots \ldots$.4

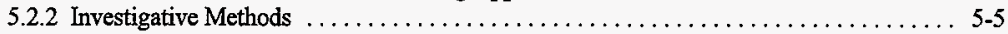

5.2.2.1 Existing Hanford Site Hydrogeologic Information $\ldots \ldots \ldots \ldots \ldots \ldots \ldots .5-5$

5.2 .2 .2 General Well Design . . . . . . . . . . . . . . . . . . . . . . . . $5-5$

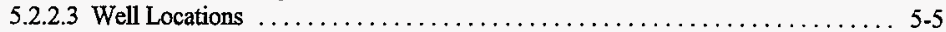

5.2.2.4 Downgradient and Upgradient Interim Status Wells $\ldots \ldots \ldots \ldots \ldots \ldots \ldots . .6-6$

5.2.2.5 General Hydrogeologic Investigative Techniques $\ldots \ldots \ldots \ldots \ldots \ldots \ldots \ldots$ 5-6

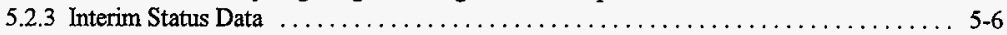

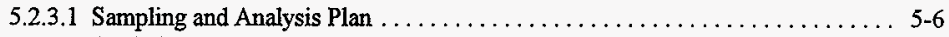

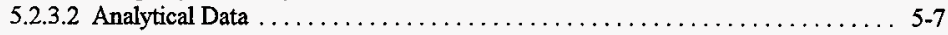

5.3 AQUIFER IDENTIFICATION $[\mathrm{D}-10 \mathrm{c}] \ldots \ldots \ldots \ldots \ldots \ldots \ldots \ldots \ldots \ldots \ldots \ldots \ldots \ldots \ldots, 8$

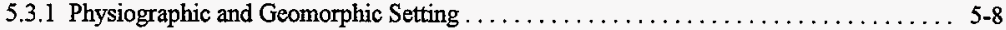

5.3 .2 Climate and Meteorology $\ldots \ldots \ldots \ldots \ldots \ldots \ldots \ldots \ldots \ldots \ldots \ldots \ldots \ldots \ldots \ldots$

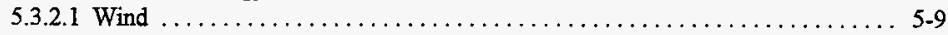

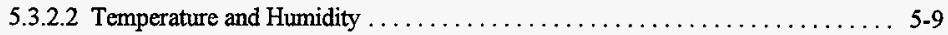

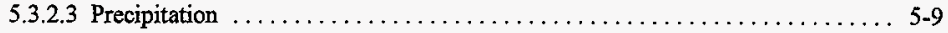

5.3 .3 Regional Geology .................................. $5-10$

5.3 .4 Regional and Hanford Site Hydrology $\ldots \ldots \ldots \ldots \ldots \ldots \ldots \ldots \ldots \ldots \ldots \ldots \ldots \ldots \ldots \ldots \ldots$

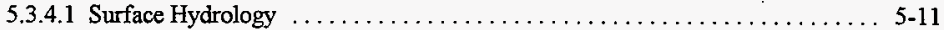

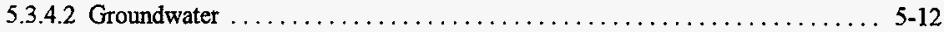

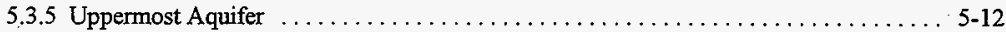

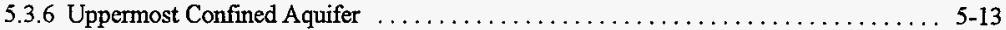

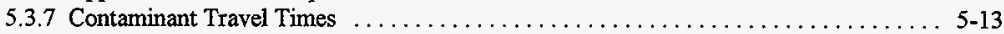

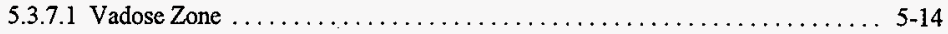

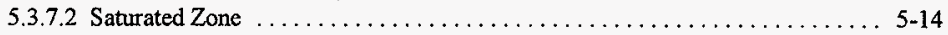

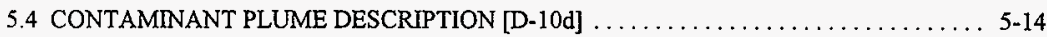

5.4 .1 Radionuclide Contamination .............................. 5-15

5.4 .2 Nonradioactive Contamination $\ldots \ldots \ldots \ldots \ldots \ldots \ldots \ldots \ldots \ldots \ldots \ldots \ldots \ldots \ldots \ldots \ldots, 5,15$

5.5 DETECTION MONITORING PROGRAM [D-10e] ................... 5-15

5.5.1 Indicator Parameters, Waste Constituents, Reaction Products to be Monitored

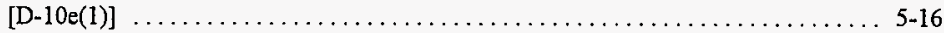

5.5.1.1 Dangerous Waste Characterization [D-10e(1)(a)] ................. 5-16

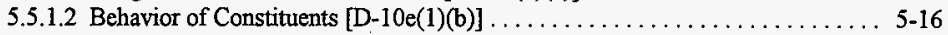

5.5.1.3 Detectability $[\mathrm{D}-10 \mathrm{e}(\mathrm{l})(\mathrm{c})] \ldots \ldots \ldots \ldots \ldots \ldots \ldots \ldots \ldots \ldots \ldots \ldots \ldots \ldots \ldots \ldots, 17$

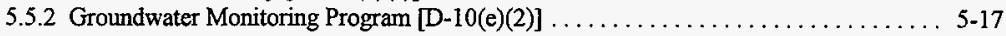

5.5.2.1 Description of Wells [D-10e(2)(a)] .......................... 5-17

5.5.2.2 Equipment Decontamination [D-10e(2)(b)] .................... 5-19 


\section{CONTENTS (cont)}

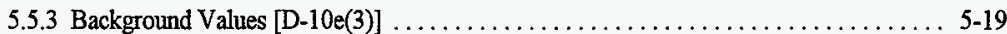

5.5.4 Sampling, Analysis, and Statistical Procedures $[\mathrm{D}-10 \mathrm{e}(4)] \ldots \ldots \ldots \ldots \ldots \ldots \ldots . \ldots \ldots$

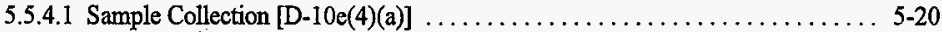

5.5.4.2 Sample Preservation and Shipment [D-10e(4)(b)] . . . . . . . . . . . 5-21

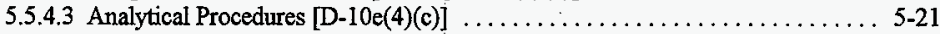

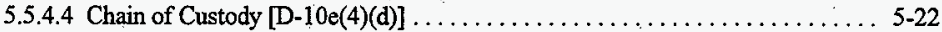

5.5.4.5 Additional Requirements for Compliance Point Monitoring

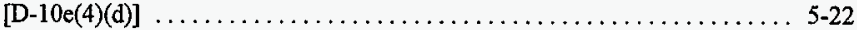

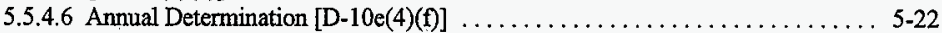

5.5.4.7 Statistical Determination for Detection Monitoring Program

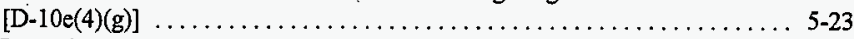

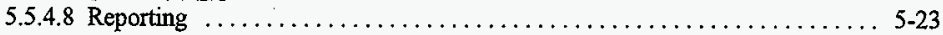

5.6 COMPLIANCE MONITORING PROGRAM [D-10f] $\ldots \ldots \ldots \ldots \ldots \ldots \ldots \ldots \ldots \ldots \ldots$

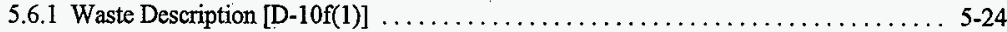

5.6.2 Characterization of Contaminated Groundwater $[\mathrm{D}-10 \mathrm{f}(2)] \ldots \ldots \ldots \ldots \ldots \ldots \ldots . \quad 5-24$

5.6.3 Dangerous Constituents to be Monitored $[\mathrm{D}-10 \mathrm{f}(3)] \ldots \ldots \ldots \ldots \ldots \ldots \ldots \ldots . \ldots \ldots$

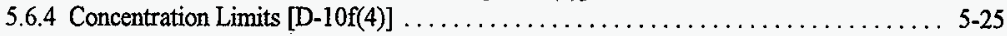

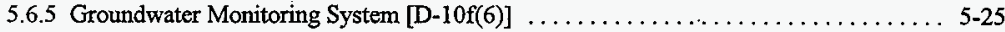

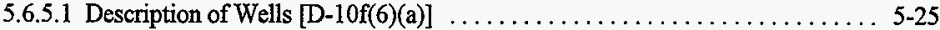

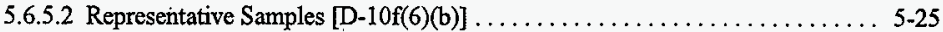

5.6.5.3 Location of Background Monitoring Wells that Are Not Upgradient

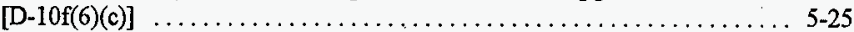

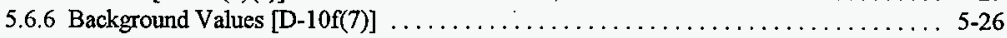

5.6.7 Sampling, Analysis, and Statistical Procedures $[\mathrm{D}-10 \mathrm{f}(8)] \ldots \ldots \ldots \ldots \ldots \ldots \ldots . \ldots \ldots$

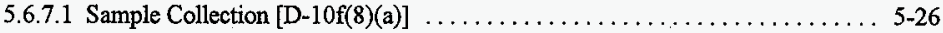

5.6.7.2 Additional Requirements for Compliance Point Monitoring

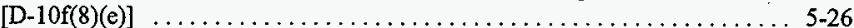

5.6.7.3 Annual Determination of Hydraulic Gradient [D-10f(8)(f)] . . . . . . . . . . 5-27

5.6.7.4 Statistical Determination for Compliance Monitoring Program

[D-10f(8)(g)]

5.7 CORRECTIVE ACTION PROGRAM $[\mathrm{D}-10 \mathrm{~g}] \ldots \ldots \ldots \ldots \ldots \ldots \ldots \ldots \ldots \ldots \ldots \ldots \ldots \ldots \ldots \ldots$

\section{FIGURES}

5-1. Generalized Configuration for a Detection Monitoring Groundwater Well System ........... F5-1

5-2. Flow Chart for Selection of Appropriate Statistical Method Used for Data Interpretation . . . . . . . F5-2

5-3. Location of Bounding Structures of the Pasco Basin $\ldots \ldots \ldots \ldots \ldots \ldots \ldots \ldots \ldots \ldots \ldots \ldots \ldots$

5-4. Generalized Stratigraphic Column of Formations at the Hanford Site . . . . . . . . . . . F5-4

5-5. Generalized Geologic Cross-Section Through the Hanford Site $\ldots \ldots \ldots \ldots \ldots \ldots \ldots \ldots \ldots$ F5-5

$5-6$. Water Table Map of the Hanford Site $\ldots \ldots \ldots \ldots \ldots \ldots \ldots \ldots \ldots \ldots \ldots \ldots \ldots \ldots \ldots$ F5-6

5-7. Distribution of Tritium on the Hanford Site $\ldots \ldots \ldots \ldots \ldots \ldots \ldots \ldots \ldots \ldots \ldots \ldots \ldots \ldots$ F5-7 


\subsection{GROUNDWATER MONITORING FOR LAND-BASED UNITS [D-10]}

This chapter describes the groundwater monitoring activities for land-based TSD units (dangerous waste surface impoundment, land treatment, or landfill units) by addressing the provisions identified in Section D-10 of Ecology's permit application guidance (Ecology 1987 and 1996). Furthermore, the chapter discusses groundwater monitoring provisions contained in Condition II.F. of the HF RCRA Permit (DW Portion). The general groundwater monitoring information contained in this chapter (e.g., Section 5.3, "Aquifer Identification") need not be duplicated in the Unit-Specific Portion of the Hanford Facility Dangerous Waste Permit Application, but can be cross-referenced as appropriate. Pertinent information also can be cross-referenced in preclosure work plan, closure work plan, closure plan, closure/postclosure plan, or postclosure permit application documentation (refer to Chapter 2.0, Section 2.5).

Currently, Hanford Facility RCRA groundwater monitoring activities are structured to provide groundwater monitoring information for individual land-based TSD units. This approach was outlined in the original Tri-Party Agreement and largely has been retained throughout subsequent amendments of the Tri-Party Agreement and throughout interactions with the regulators. This chapter primarily addresses this TSD unit-specific groundwater monitoring approach. However, a need to more fully integrate Hanford Site groundwater monitoring activities has become increasingly evident. Such integration also would support the Cost and Management Efficiency Initiative (Ecology et al. 1994). A collaborative effort to develop a groundwater monitoring strategy based on the data quality objective process (EPA540-R-93-007land EPA 600/R-96-055)currently is underway. This process is being used to justify why data are being collected, how the data are expected to be used to make decisions, and how much data are needed to meet criteria specified by the stakeholders. The results of this effort will be incorporated through the provision of a revised Hanford Site Ground Water Protection Management Plan (DOE/RL-89-12).

A summary of RCRA groundwater monitoring activities on the Hanford Facility is contained in the Hanford Site Groundwater Monitoring for Fiscal Year 1997 (PNNL-11793). This report summarizes monitoring information for two land-based 'operating' TSD units, LERF and LLBG (refer to Chapter 4.0, Sections 4.1.2.4 and 4.1.2.8, respectively). A more detailed description of the groundwater programs for these units is contained in the Unit-Specific Portion of this permit application [i.e., DOE/RL-97-03 (LERF) and DOE/RL-88-20 (LLBG)]. The aforementioned Hanford Site Groundwater Monitoring Report also summarizes monitoring information for land-based TSD units 'undergoing closure' (refer to Chapter 2.0, Section 2.5). For certain of these TSD units, more detailed information is contained in closure plan/postclosure plan documentation. The content of this chapter focuses on groundwater monitoring for 'operating' TSD units. However, this information also is relevant to TSD units 'undergoing closure'.

Unit-specific groundwater monitoring programs are designed to comply with applicable regulations and agreements for TSD units operating under both interim status (WAC 173-303-400 and WAC 173-303-805) and final status (WAC 173-303-645 and WAC 173-303-806). The following is a generalized discussion of the RCRA groundwater monitoring requirements for a TSD unit. This discussion provides background information relevant to subsequent, more specific groundwater monitoring discussions. In these discussions, the term 'RCRA' refers to both federal and state groundwater monitoring regulations as appropriate.

The RCRA groundwater monitoring programs are implemented under two types of groundwater monitoring regulations: interim status and final status. A land-based TSD unit operating under interim status must have implemented a monitoring program capable of determining the impact of the TSD unit on 
groundwater quality in the uppermost aquifer beneath the TSD unit. The interim status program can take the form of either detection monitoring or assessment monitoring. An interim status corrective action order, however, may be issued (by the regulators) when the facility releases hazardous waste to the environment. 'Detection-level' monitoring also is referred to as 'indicator evaluation' monitoring in the regulations for interim status facilities; 'detection-level' is used throughout this chapter to refer to this type of monitoring for both interim status and final status TSD units. At a minimum, an interim status detection monitoring system must include one upgradient and three downgradient groundwater monitoring wells. A generalized configuration for such a system is shown in Figure 5-1. The LLBG and LERF currently are monitored under interim status regulations. Final status groundwater requirements for the LERF, which has been incorporated into the HF RCRA Permit (DW Portion), will take effect when Ecology approves the final status groundwater monitoring plan. Final status groundwater requirements for the LLBG will take effect when this TSD unit is incorporated into the HF RCRA Permit (DW Portion). A groundwater monitoring plan for LLBG that meets final status requirements may be implemented before this time if approved by Ecology.

Before the installation of a detection monitoring system, a groundwater monitoring plan must be developed and followed. This plan details well locations, procedures, requirements for vadose zone and aquifer characterization, and well installation; sample collection, preservation, and transportation; and sample analysis. Chain-of-custody control must be developed and followed. Additionally, relevant components of the DQO process are to be incorporated in a site-specific 120 groundwater monitoring plan and a quality assurance project plan (QAPjP). Methods to be used to interpret groundwater monitoring data also are specified.

Under interim status, groundwater monitoring data obtained from the detection monitoring system are used to establish background groundwater quality through quarterly sampling and analysis of several water quality parameters (as specified in 40 CFR 265.92) for 1 year. After the first year, sampling and analysis must be conducted at least annually for the parameters related to groundwater quality, and semiannually for the indicator parameters related to groundwater contamination (i.e., $\mathrm{pH}$, specific conductance, total organic carbon, and total organic halogen).

If a confirmed statistically significant evidence of contamination (i.e., as revealed in indicator parameters) in the groundwater exists, the regulatory agency is notified and a groundwater quality assessment monitoring plan developed. The objective of assessment monitoring is to determine if dangerous waste or dangerous waste constituents from the regulated unit have entered the groundwater and, if so, the concentration, rate, and extent of migration of the constituents in the groundwater. This determination is achieved through quarterly sampling and could require the installation of additional wells and/or additional sampling of existing wells. Monitoring must continue during the active life of the facility, and for disposal facilities during the postclosure care period unless the regulated unit is to be clean closed.

For final status TSD units, there could be a three-stage groundwater monitoring program that involves detection, compliance, and corrective action, as warranted (EPA-230/02-89-042). A final status detection monitoring system must include both background (generally upgradient) and compliance (generally downgradient) wells (Figure 5-1). Wells installed to support interim status could be used as final status monitoring wells. A groundwater monitoring plan is developed to address each final status monitoring stage, using the DQO process. Also specified in each plan are methods to be used to conduct and interpret groundwater monitoring data. The choice of an appropriate statistical method depends on the monitoring stage and the nature of the data. A flow chart that guides the selection of the appropriate method to be used for data interpretation is presented in Figure 5-2. 
The final status detection monitoring program is designed to determine whether a RCRA-regulated unit has adversely affected the groundwater quality in the uppermost aquifer beneath the site. This is accomplished by testing for statistically significant changes in concentrations of constituents of interest in a downgradient monitoring well relative to baseline levels. These baseline levels could be obtained from upgradient (or background) wells, and are referred to as interwell (or between-well) comparisons. Alternatively, if baseline values are obtained from historical measurements from that same well, the comparisons are referred to as intrawell (or within-well) comparisons. If a statistically significant increase (or $\mathrm{pH}$ decrease) over baseline condition occurs in a downgradient compliance well, a compliance monitoring program might be initiated. A compliance monitoring program must be initiated after the owner and/or operator cannot successfully demonstrate that a source other than the regulated TSD unit has caused the contamination or that the increase resulted from an error in sampling, analysis, or evaluation.

In a compliance monitoring program, the monitoring objective is to determine whether groundwater protection standards have been exceeded. This is accomplished by comparing the concentration of a constituent of concern to groundwater protection standards, such as an alternate concentration limit, maximum concentration limit, background, health-based standards, or any other standards that constitute applicable, relevant, and appropriate requirements. Monitoring must continue at the TSD unit, if a detection monitoring is conducted, through the postclosure care period.

A third stage, a corrective action program, is initiated if a groundwater protection standard is exceeded at the point of compliance. Exceeded is defined as statistically significant evidence of increased contamination. Corrective action could consist of additional vadose zone and aquifer characterization and the removal or treatment in place of the dangerous constituents.

The remainder of this chapter includes a more specific discussion of the implementation of Hanford Facility groundwater monitoring activities.

\subsection{EXEMPTION FROM GROUNDWATER PROTECTION REQUIREMENTS [D-10a]}

An exemption from the groundwater monitoring requirements as allowed under WAC 173-303-645(I)(b)(I), (ii), and (iv) is not requested at this time.

\subsection{INTERIM STATUS PERIOD GROUNDWATER MONITORING DATA [D-10b]}

In 1986, interim status groundwater monitoring for four Hanford Facility TSD units was implemented through a Consent Agreement and Compliance Order (Ecology DE-86-133). Three of these TSD units are undergoing closure and are currently in interim status or in final status. The fourth TSD unit, the LLBG, is an 'operating' unit. As specified in the Tri-Party Agreement, permit application documentation for the LLBG was submitted in 1989 (DOE/RL-88-20); in accordance with the Class 3 Permit Modification Schedule (refer to Chapter 2.0, Section 2.1.1.3.3), the status of this TSD unit is anticipated to change from interim to final in 1999. Final status is sought for at least one other 'operating' TSD unit requiring a groundwater monitoring system, the LERF (DOE/RL-97-03). The initial permit application documentation for the LERF was submitted in June 1991; in accordance with the Class 3 Permit Modification Schedule (refer to Chapter 2.0, Section 2.1.1.3.3), the status of this TSD unit change from interim to final in 1998. With the exception of the 183-H Solar Evaporation Basins and the 300 Area Process Trenches (refer to Chapter 2.0, Section 2.5.1.1.2), 
Chapter 2.0, Section 2.5) are not scheduled to be entered into the HF RCRA Permit (DW Portion) until 1998 or later.

The interim status groundwater monitoring program implemented for a TSD unit is summarized in the following sections. The information presented includes a (1) summary of the existing hydrogeologic data, (2) description of the general well design, (3) discussion of the groundwater monitoring system design,

(4) summary of the interim status groundwater sampling and analysis plan for monitoring wells, and

(5) preliminary description of the statistical procedures used to assess water quality results. In addition, a summary is presented on the techniques and methods used to characterize the uppermost aquifer beneath the Hanford Site in support of the monitoring.well system design.

\subsubsection{Interim Status Groundwater Monitoring Approach}

A specific investigative approach is taken to support the design of each TSD unit groundwater monitoring system in the interim status period. This approach consists of the following two elements.

- Establish an initial groundwater monitoring well system from which stratigraphic, hydrogeologic, and background water quality information can be obtained for the uppermost aquifer. Data from this initial system are used to determine the need for additional monitoring wells.

- Provide hydrogeologic properties of the uppermost aquifer system beneath the TSD unit using data collected from the monitoring well system and from previously collected or published data.

Groundwater monitoring plans are developed for each TSD unit to address these elements. These groundwater monitoring plans contain specific details regarding characterization needs and details regarding the monitoring system design. The groundwater monitoring plans also contain a sampling and analysis plan.

Groundwater monitoring plans were developed for the two 'operating' TSD units: LLBG (WHC-SD-EN-AP-015) and LERF (WHC-SD-AP-024). Two assessment monitoring plans also have been prepared for the LLBG (WHC-SD-EN-AP-021 and -022). In each case, the assessment monitoring indicated that the detection was a 'false positive', and the LLBG resumed detection monitoring. Interim status groundwater monitoring plans also have been developed for land-based TSD units 'undergoing closure' (refer to Chapter 1.0, Table 1-1 and Chapter 2.0, Section 2.5).

As part of groundwater monitoring system installation, subsurface sediment samples are collected during drilling at each well location. Grab samples, as a minimum, are described and classified in the field (Appendix 2B) and are considered adequate for general geologic and some physical/chemical analysis. Selected samples, collected by various techniques, are submitted to a laboratory for analyses to determine various physical and chemical properties.

Data collected from installation of the monitoring system and from previously collected or published data are summarized in a characterization report. Characterization reports have been completed for both land-based 'operating' TSD units for which final status is sought and are summarized in the respective Part B permit application documentation [i.e., DOE/RL-88-20 (LLBG) and DOE/RL-97-03 (LERF)]. Groundwater monitoring information for land-based TSD units 'undergoing closure' is summarized in 'borehole completion data packages' (Appendix 2B), Hanford Site groundwater monitoring annual reports, and in quarterly reports. 
Groundwater is collected and analyzed from monitoring wells under the interim status programs. During the first year of monitoring, samples are collected quarterly to establish background water quality for each well. Statistical evaluations of subsequent data are compared with these background concentrations to provide an indication of whether dangerous constituents from the TSD unit are significantly affecting the groundwater quality.

The annual groundwater monitoring report provides an interpretation of the data obtained through the sampling and analysis programs for the interim status groundwater projects, including such information for the LLBG, LERF, and other RCRA units. Groundwater monitoring results have been, and will continue to be, reported in the annual groundwater monitoring report released by March 1 of each calendar year.

\subsubsection{Investigative Methods}

The techniques and methods used to assess the hydrogeologic properties of the uppermost aquifer beneath the Hanford Site are summarized in this section.

5.2.2.1 Existing Hanford Site Hydrogeologic Information. Hydrogeologic information has been collected since activities began on the Hanford Site in the mid-1940s. Much of the information on subsurface geology is derived from the analyses and interpretations of boreholes and wells completed in and around the Hanford Site. These data are available in formal borehole data packages and in the well file library (refer to Chapter 12.0, Section 12.1.26). Some of the historical data have been entered into the Hanford Environmental Information System (HEIS). Data used in the Unit-Specific Portion are documented in groundwater monitoring plans, reports, and in unit-specific Part B permit application documentation.

There are numerous reports that provide interpretations of raw data. Much of what is known about the geology, hydrology, climatology, and meteorology of the Hanford Site has been compiled in the Consultation Draft Site Characterization Plan (DOE/RW-0164, volumes 1,2, and 3). Hanford Site studies include a summary of groundwater quality (WHC-EP-0260) and a compilation of water table elevation maps (WHC-EP-0394).

5.2.2.2 General Well Design. As required by WAC 173-303-400(3)(a) and 40 CFR 265.91, the interim status groundwater monitoring system includes the completion of monitoring wells to obtain representative groundwater samples from the uppermost aquifer beneath each of the land-based TSD units. Wells are designed to meet the requirements of WAC 173-160.

In some circumstances, wells that existed before implementing the RCRA groundwater monitoring requirements are used as part of the monitoring network. Authorization and criteria for using groundwater wells that existed before the lists of the RCRA parameters were established are provided in a letter from Ecology and the EPA dated July 16, 1990 (EPA and Ecology 1990). No pre-RCRA wells currently are used for RCRA monitoring at the LLBG or the LERF.

Details on the individual well completion methods are provided in the TSD unit-specific groundwater monitoring plans. Specifications for well designs (e.g., WHC-S-014) and procedures for performing the well installations are contained in contractor procedure manuals. 
1 5.2.2.3 Well Locations. The locations of the interim statas monitoring wells for the individual TSD units 2 are documented in the TSD unit-specific groundwater monitoring plans, unit-specific borehole data packages, 3 and in the Unit-Specific Portion of this permit application.

5.2.2.4 Downgradient and Upgradient Interim Status Wells. At least one monitoring well is installed hydraulically upgradient from each TSD unit. Their number, location(s), and depth(s) must be sufficient to yield groundwater samples that are representative of the background groundwater quality in the uppermost aquifer beneath the TSD unit and not impacted by the TSD unit.

There must be at least three groundwater monitoring wells located hydraulically downgradient of the TSD boundary (e.g, point of compliance) (Figure 5-1). Their number, locations, and depths of the wells are designed for the detection of any statistically significant amount of dangerous waste or dangerous waste constituents that might migrate from the TSD unit to the uppermost aquifer.

The upgradient and downgradient well locations for each TSD unit are selected on the basis of water table elevations and any other applicable information available at the time of well installation. The well locations for TSD units are found in the interim status groundwater monitoring plans and in the Unit-Specific Portion of this permit application. Specific well location coordinates and elevations are found in the well information system (WIS) database.

5.2.2.5 General Hydrogeologic Investigative Techniques. Characterization of the hydrogeologic properties of land-based TSD units could be based on information gained from borehole sediment samples, geophysical logging, aquifer testing, water level measurements, and other pertinent sources of information (EPA 1986b). The unit-specific permit application documentation contains details regarding sample collection intervals and tests performed.

Limited hydraulic properties have been obtained from field determinations as well as permeameter testing in the laboratory. Aquifer testing (constant-discharge production and recovery phases) was performed primarily before 1989 . Increased restrictions on purgewater disposal resulted in the use of alternative testing methods from 1989 through September 15, 1991. During this period, slug testing was the preferred method used to obtain field information on the aquifer properties. Descriptions of the test method used to obtain hydraulic property information are provided in groundwater monitoring plans and in unit-specific permit application documentation.

\subsubsection{Interim Status Data}

Groundwater monitoring activities performed during the interim status period are summarized in this section.

5.2.3.1 Sampling and Analysis Plan. Sampling and analysis plans are found in the unit-specific groundwater monitoring plans. The aspects of the groundwater sampling and analysis plans that have been used, and currently are being used for the interim status program monitoring wells, are described in this section. Representative groundwater samples from the uppermost aquifer beneath the Hanford Facility are obtained and analyzed for the purpose of detecting potential contaminant releases from TSD units. All interim status sampling activities on the Hanford Facility currently are performed in accordance with SW-846 protocol or an equivalent EPA-approved method (EPA-0230). 
The following sections describe the general methods used in the acquisition of groundwater samples.

5.2.3.1.1 Static Water-Level Measurements. The static water level is measured, recorded, and remeasured until reproducible results are obtained before purging or sampling monitoring wells. Procedures for water level measurements are found in subcontractor procedure manuals.

5.2.3.1.2 Well Purging. Monitoring wells are purged before sample collection to obtain groundwater samples that are representative of groundwater. Most monitoring wells are purged until a minimum of three casing volumes of water have been removed from the wells; the wells may be sampled after field parameters stabilize (Section 5.2.3.1.4). Methods of minimizing or eliminating purge volumes before sampling currently are being evaluated.

5.2.3.1.3 Sample Withdrawal. After the monitoring well has been purged, the pumping rate is reduced and samples are withdrawn. Multiple groundwater samples are obtained for laboratory analyses during the sampling event. Samples typically are collected and bottled in the following order:

- Bottles with septum caps (volatiles)

- Unfiltered samples (major-ions, cyanide, semivolatiles, metals)

- Filtered samples (metals).

5.2.3.1.4 Field Analyses. Temperature, $\mathrm{pH}$, turbidity, and specific conductance are measured and recorded during well purging and sample withdrawal. Groundwater samples for laboratory analysis are generally not collected until each of these parameters has stabilized.

5.2.3.1.5 Chain of Custody. Chain-of-custody procedures are followed in collecting interim status data to ensure the compositional integrity of groundwater samples from the time of collection through laboratory analysis and data reporting.

5.2.3.1.6 Quality Assurance and Quality Control Procedures. Quality assurance and quality control procedures are applied to both field and laboratory data to ensure the reliability and validity of the data. The Tri-Party Agreement (Article XXXI, Paragraph 105, and Sections 6.5 and 7.8 of the Tri-Party Agreement Action Plan) also specifies quality assurance and quality control requirements that are to be implemented.

5.2.3.2 Analytical Data. Analytical data on the interim status groundwater program are presented in the following sections.

5.2.3.2.1 Groundwater Elevations. Groundwater elevation data have been obtained since RCRA groundwater monitoring began. Water levels also are available for existing wells prior to the RCRA groundwater monitoring program. Water level data are compiled into the HEIS database. Hanford sitewide groundwater maps are produced at least annually.

5.2.3.2.2 Results of Water Quality Analyses. Quarterly samples are collected for the first year to establish background water quality. Constituents analyzed for are specified by 40 CFR 265.92 (b)(1)(2)(3). Specific analytical parameters are specified in unit-specific permit application documentation. After the first year, the wells are sampled for 40 CFR 265.92 (b)(2) groundwater quality parameters at least annually and are sampled for 40 CFR 265.92 (b)(3) indicator parameters and site-specific parameters semiannually. The TSD units in assessment-level monitoring require sampling quarterly or an agreed upon sampling frequency. 
The constituents analyzed for are detailed in the groundwater monitoring plans and in the unit-specific permit application documentation.

All groundwater quality data from the monitoring well network are entered into the HEIS database for permanent storage and are available electronically. Data from the HEIS database may be downloaded to smaller databases, such as the Geosciences Data Analysis Toolkit (GeoDAT) for data validation, data reduction, and trend analysis.

5.2.3.2.3 Statistical Results. Statistical analyses of the sampling results for indicator parameters (including $\mathrm{pH}$, specific conductance, total organic carbon, and total organic halogens) are discussed in unit-specific permit application documentation. Detailed statistical analysis methods have been documented (WHC-SA-1124-FF). Results of statistical analyses are presented in groundwater monitoring annual reports (e.g., DOE/RL-91-03).

\subsection{AQUIFER IDENTIFICATION [D-10c]}

The characteristics of the uppermost aquifer beneath the Hanford Site and regional hydrogeologic factors influencing this aquifer are summarized in the following section. This summary begins with a brief description of the regional physiographic and geomorphic setting of the Hanford Site. The climate and meteorology of the region also are summarized to address aquifer recharge potential from precipitation. An overview of the regional geologic framework follows, as this framework provides a major influence on aquifer characteristics. A description of the physical characteristics of the uppermost aquifer and a summary of contaminant travel time determinations comprise the remainder of this section. Hydrogeologic terms used in this discussion are defined in the glossary contained in Appendix 2B. A brief parenthetical explanation follows the initial use of these terms within the text.

The hydrogeologic information discussed for the Hanford Site also applies to the Hanford Facility, unless otherwise designated.

\subsubsection{Physiographic and Geomorphic Setting}

This section addresses the physiographic and geomorphic setting of the Hanford Site, or a description of the nature and origin of landforms. The Hanford Site is situated within the Pasco Basin of south-central Washington (Figure 5-3). The Pasco Basin is bounded on the north by the Saddle Mountains, on the west by Umtanum Ridge, Yakima Ridge, and the Rattlesnake Hills, and on the south by Rattlesnake Mountain, all anticlinal folds of the Yakima Fold Belt (a physiographic subdivision of the Columbia Plateau characterized by anticlinal upwarps and synclinal downwarps of the underlying bedrock). The Pasco Basin is bounded on the east by the Palouse slope, a monocline (broad fold) that inclines to the east (Figure 5-3).

Surface topography seen at the Hanford Site is the result of: (1) anticlinal ridges, (2) Pleistocene cataclysmic flooding (flooding resulting from glacial activity occurring north of the Hanford Site 13,000 to 10,000 years ago), (3) Holocene eolian activity (relatively recent wind activity), and (4) landsliding. Since the end of the Pleistocene, winds have locally reworked the flood sediments, depositing dune sands in the lower elevations and loess (windblown silt) around the margins of the Pasco Basin. Sand dunes have largely stabilized except where these dunes have been reactivated because of the disturbance of anchoring vegetation (WHC-SD-ER-TI-0003). 


\subsubsection{Climate and Meteorology}

The Hanford Site is located in a semiarid desert area. The climate in the vicinity of the Hanford Site is largely influenced by the rain-shadow effect of the Cascade Range located in western Washington. This effect results in cold air drainage across the region that largely controls the wind regime of the Hanford Site.

Climatological data have been collected at the Hanford Meteorological Station, located between the 200 Areas, since 1945 (PNL-6415). Temperature and precipitation data also are available from nearby locations for the period 1912 through 1943. A summary of these data through 1980 has been published (PNL-11793). Data from the Hanford Meteorological Station are representative of the general climatic conditions for the region and describe the specific climate of the 200 Areas Plateau.

5.3.2.1 Wind. Prevailing wind directions on the 200 Areas Plateau are from the northwest in all months of the year (refer to Chapter 2.0, Figure 2-8). Secondary maxima occur for southwesterly winds.

Monthly average wind speeds are lowest during the winter months, averaging 10 to 11 kilometers per hour, and highest during the summer, averaging 15 to 16 kilometers per hour. Wind speeds that are well above average usually are associated with southwesterly winds. However, the summertime drainage winds generally are northwesterly and frequently reach 50 kilometers per hour. Estimates of wind extremes have been summarized (PNL-4622). Information on the likelihood and frequency of strong winds and tornadoes in the region have been summarized in a final environmental impact statement (DOE/EIS-0113), the Hanford Meteorological Station climatological summary (PNL-4622), and by the National Severe Storms Forecast Center.

5.3.2.2 Temperature and Humidity. Ranges of daily temperatures vary of $1.6^{\circ}$ from normal maxima $\mathrm{C}$ in early January to $35^{\circ} \mathrm{C}$ in late July. The record maximum temperature is $46^{\circ} \mathrm{C}$, and the record minimum temperature is $-32.7^{\circ} \mathrm{C}$.

The annual average relative humidity at the Hanford Meteorological Station is 54 percent. It is highest during the winter months, averaging approximately 75 percent, and lowest during the summer months, averaging approximately 35 percent.

5.3.2.3 Precipitation. Precipitation measurements have been made at the Hanford Meteorological Station since 1945. Average annual precipitation at the Hanford Meteorological Station is 16 centimeters per year. Most of the precipitation occurs during the winter, with nearly half of the annual amount occurring in the months of November through February. Days with greater than 1.3 centimeter precipitation occur less than 1 percent of the year. Rainfall intensities of 0.5 inch ( 1.3 centimeter) per hour persisting for 1 hour are expected once every 10 years. Rainfall intensities of 2.54 centimeter per hour for 1 hour are expected only once every 500 years. Winter monthly average snowfall ranges from 0.76 centimeter in March to 13.5 centimeter in January. The record snowfall of 59.4 centimeters occurred in January 1950 . Snowfall accounts for approximately 38 percent of all precipitation during the months of December through February. 


\subsubsection{Regional Geology}

The regional geology provides the framework for understanding the stratigraphic (rock layers) and structural (rock deformation) controls on the aquifers beneath the Hanford Site. An overview of the regional geology and a description of the primary stratigraphic units that comprise these aquifers are provided in this section.

The Hanford Site lies in the Pasco Basin near the eastern limit of the Yakima Fold Belt. The Pasco Basin is divided by the Gable Mountain anticline into the Wahluke syncline to the north and the Cold Creek syncline to the south. The Pasco Basin is underlain by Miocene-aged (approximately 17 to 8.5 million years before present) volcanic (molten rock) flows of the Columbia River Basalt Group and late Miocene- to Pleistocene-aged sediments (approximately 10.5 million to 12,000 years before present) that overlie the basalts. The basalts and sediments thicken into the Pasco Basin and generally reach maximum thicknesses in the Cold Creek syncline in the vicinity of the 200 Areas. Hanford Site structure and stratigraphy are illustrated in Figures 5-3 and 5-4, respectively, and described in WHC-SD-ER-TI-0003. A brief review of this information follows.

The Columbia River Basalt Group is greater than 3,658-meters thick beneath the Pasco Basin. The sequence of volcanic flows within the Pasco Basin can be divided into the Grande Ronde, Wanapum, and Saddle Mountains formations (major rock divisions) (listed from oldest to youngest). The youngest formation of the Group, the Saddle Mountain Basalt, is characterized by a sequence of volcanic flows and intercalated sedimentary units called interbeds.

Late Miocene to Quaternary sediments overly the basalts. Most of this sedimentary sequence can be divided into two main units: the Ringold Formation of late Miocene to middle-Pliocene age (approximately 10.5 million to 3 million years before present) and the Hanford formation of Pleistocene to Recent age (approximately 1 million to 12,000 years before present).

The Ringold Formation was formed by fluvial-lacustrine (stream-lake) processes. This formation comprises the basal part of the sedimentary sequence above the basalt. The Ringold Formation is up to 185-meters thick at the Hanford Site in the deepest part of the Cold Creek syncline south of the 200 West Area, and up to 170-meters thick in the western Wahluke syncline. The Ringold Formation pinches out against Gable Mountain, Yakima Ridge, Saddle Mountains, and Rattlesnake Mountain anticlines. The Ringold Formation is largely absent in the northern and northeastern parts of the 200 East Area and adjacent areas to the north in the vicinity of West Lake, located south of Gable Mountain. The Ringold Formation is composed of unindurated to semi-indurated (loose to semi-hardened) clay, silt, fine to coarse-grained sand, or granule to cobble gravel that can be divided into five facies (lateral subdivisions of a rock type) (WHC-SD-EN-EE-004). The five facies include: (1) fluvial gravel (generally with a fine to medium sand matrix); (2) fluvial sand; (3) overbank deposits (sediments deposited beyond the natural levee of a stream or river during a flooding event) and paleosols (ancient soils) composed of silty sand to clay; (4) lacustrine sandy silts to clays; and (5) basaltic alluvium or fanglomerate deposited at the foot of ridges (anticlines).

The distribution of facies associations within the Ringold Formation forms the basis for three stratigraphic subdivisions (WHC-SD-EN-EE-004). The first of these subdivisions forms the lower half of the formation and is characterized by intervals dominated by fluvial gravel and sand (facies 1 and 2) that interfinger with intervals containing fine-grained deposits (facies 3 and 4). Interstratified deposits typical of the fluvial sand (facies 2) and overbank-paleosol facies (facies 3) associations dominate the second 
subdivision. The third and uppermost subdivision is dominated by the lacustrine facies association (facies 4). Facies 5 are mainly found in the vicinity of the anticlinal ridges to the west and north of the Hanford Site.

Other less extensive stratigraphic units within the Pasco Basin overlie the Ringold Formation and underlie the Hanford formation. These units include a laterally discontinuous Plio-Pleistocene unit and pre-Missoula gravels. The pre-Missoula gravels are approximately equivalent in age to the Plio-Pleistocene unit.

The Hanford formation was formed by glaciofluvial processes. During Pleistocene glaciation, eastern Washington was subjected to a number of cataclysmic floods that resulted from the breakup of ice dams impounding glacial lakes in Idaho, Montana, and northeastern Washington. The Hanford formation generally can be divided into two main facies: coarse-grained or gravelly deposits and fine-grained or sandy and silt deposits. The Hanford formation also is commonly divided into two informal members: the Pasco gravels and the Touchet beds (DOE/RW-0164). The Pasco gravels generally correspond to the gravelly facies, and the Touchet beds correspond to the sandy to silty facies. The Hanford formation is thickest in the Cold Creek bar in the vicinity of the 200 West and 200 East Areas where the formation is up to 64 meters thick. Hanford formation deposits are absent on ridges approximately 360 meters above sea level.

Holocene surficial deposits consist of silt, sand, and gravel that form a thin (less than 4.9-meter) veneer across much of the Pasco Basin. These sediments were deposited by a mix of eolian and alluvial processes during the past 10,000 years.

Details of the geology for 'operating' TSD units for which final status is sought are provided in groundwater monitoring plans included in the unit-specific portion.

\subsubsection{Regional and Hanford Site Hydrology}

The regional and Hanford Site surface and groundwater hydrology are discussed in the following sections. Primary surface-water features associated with the Hanford Site and region are the Columbia River and its major tributaries, the Yakima, Snake, and Walla Walla Rivers. With regard to groundwater hydrology, the uppermost aquifer is primarily in the Ringold Formation and the vadose zone (unsaturated zone above the water table) is primarily in the Hanford formation. The Hanford formation comprises the upper 9 to 91 meters of the vadose zone throughout most of the Hanford Site, but extends below the regional water table in parts of the 200 East Area and eastward towards the Columbia River.

5.3.4.1 Surface Hydrology. Surface drainage enters the Pasco Basin from several other surrounding basins. Within the Pasco Basin, the Columbia River is joined by major tributaries including the Yakima, Snake, and Walla Walla Rivers. Two intermittent streams traverse through the Hanford Site: Cold Creek and Dry Creek (refer to Chapter 2.0, Section 2.2.1.4). Water drains through these creeks during the wetter winter and spring months. No perennial streams originate within the Pasco Basin.

Total estimated precipitation over the Pasco Basin averages 16 centimeters per year (Section 5.3.2.3). Mean annual run-off from the Pasco Basin is estimated to be less than $3.1 \times 10^{7}$ cubic meters per year, or approximately 3 percent of the total precipitation. Recharge from infiltration of precipitation is highly variable on the Hanford Site both spatially and from year to year. The rate of natural recharge depends primarily on soil texture, vegetation, and climate, and ranges from near zero, where fine-grained soils and 
1 deep-rooted vegetation are present, to $>10 \mathrm{~cm} / \mathrm{yr}(4 \mathrm{in} / \mathrm{yr})$ in areas where soils are coarse textured and bare of 2 vegetation (Gee et al. 1992; PNNL-10285).

Within the vicinity of the Hanford Site, primary surface-water features are the Columbia and Yakima Rivers. West Lake, about 4 hectares in size and less than 0.9 -meter deep, is the only natural lake within the Hanford Site. Waste water ponds, cribs, and ditches associated with waste management activities also are present on the Hanford Site.

5.3.4.2 Groundwater. Confined and semiconfined aquifer systems occur beneath the Hanford Site in the basalt flow tops, flow bottom zones, and sedimentary interbeds (DOE/RW-0164). These deeper aquifers are intercalated with aquitards consisting of basalt flow interiors. Vertical flow across the aquitards within the basalt aquifer system is inferred from water level or potentiometric surface data, but the leakage is not quantified and direct measurements are not available (DOE/RW-0164). The multiaquifer system within the Pasco Basin has been conceptualized as consisting of four primary hydrogeologic units: (1) Hanford and Ringold formation sediments, (2) Saddle Mountain Basalt, (3) Wanapum Basalt, and (4) Grande Ronde Basalt. The discussion in the following sections focuses on the uppermost aquifer systems within the Ringold and Hanford formations and within the Saddle Mountains Basalt, the aquifer comprised of the Rattlesnake Ridge interbed.

\subsubsection{Uppermost Aquifer}

The unconfined to semiconfined aquifer associated with the sedimentary units stratigraphically above the basalts is the uppermost regionally extensive aquifer beneath the Hanford Site. The water table ranges in depth from 0 meter at West Lake and the Columbia and Yakima Rivers, to greater than 106.7 meters near the center of the Hanford Site. Groundwater within this aquifer system is contained within the glaciofluvial sands and gravels of the Hanford formation and the fluvial-lacustrine sediments of the Ringold Formation. The position of the water table beneath the western portion of the Hanford Site is generally within the coarse-grained gravel units of the Ringold Formation (WHC-SD-EN-EE-004). In the northern and eastern portions of the Hanford Site, the water table is generally within the Hanford formation. Hydraulic conductivities for the Hanford formation (610 to 3,048 meters per day) are much greater than those of the coarse-grained gravel units of the Ringold Formation (186 to 930 meters per day) (RHO-RE-SR-87-24, WHC-SD-EN-EE-004). Stratigraphic divisions of these units and their hydrologic properties are discussed in detail in the geology and hydrology of the Hanford Site (WHC-SD-ER-TI-0003).

This aquifer system is approximately 152-meters thick near the center of the Pasco Basin. Laterally, the aquifer system is bounded by anticlinal basalt ridges that extend above the water table. A generalized east-west geologic cross-section showing the position of the water table and major stratigraphic units beneath the Hanford Site is presented in Figure 5-5.

The base of the uppermost aquifer generally is regarded as the basalt surface. On a local scale where the Ringold Formation is present, the silts and clays of the Formation's.lower mud unit and the Formation's fine-grained units (WHC-SD-EN-EE-004) form a confining layer. Thus, in the strict sense, the groundwater is unconfined above this layer and semiconfined below this layer.

Significant water level changes have occurred on the Hanford Site. Water levels in the uppermost aquifer have risen because of artificial recharge mechanisms. Waste water ponds on the Hanford Site have artificially recharged the uppermost aquifer below the 200 East and 200 West Areas. Recharge from the 
200 Areas waste water disposal units is estimated to be approximately 10 times the natural recharge on the

2 Hanford Site (RHO-ST-42). The increase in water table elevations was most rapid from 1950 to 1960 and 3 apparently stabilized between 1970 and 1980 , when only small increases in water table elevations occurred.

4 Waste water discharges from the 200 Areas have been reduced since 1984 and the water levels have declined

5 significantly. Other artificial recharge mechanisms include excessive application of imported irrigation water

6 or impoundment of streams.

The general direction of groundwater flow is primarily from natural recharge areas west of the Hanford Site to discharge areas toward the Columbia River. The general west-to-east flow pattern is interrupted locally by the groundwater mounds in the 200 Areas. From the 200 Areas, there is also a component of groundwater flow to the north, between Gable Mountain and Gable Butte. Figure 5-6 illustrates the water table conditions beneath the Hanford Site.

Details of the hydrology for 'operating' TSD units for which final status is sought are provided in the unit-specific groundwater monitoring plans and permit application documentation.

\subsubsection{Uppermost Confined Aquifer}

The Rattlesnake Ridge aquifer is the uppermost fully-confined aquifer system that occurs beneath the Hanford Site. As discussed previously, Ringold Formation sediments are semiconfined in some areas. The Rattlesnake Ridge aquifer consists of the flow bottom of the Elephant Mountain Basalt member, the flow top of the Pomona basalt, and the Rattlesnake Ridge interbed. The thickness of the Rattlesnake Ridge interbed, which is the principal transmissive zone within the aquifer, ranges from 15 to 25 meters beneath the 200 Areas and generally thickens toward the west (RHO-ST-42, RHO-RE-ST-12P). Erosional windows (gaps in the rock) in the Elephant Mountain basalt confining layer exist locally. This could allow hydraulic communication between the Rattlesnake Ridge aquifer and the overlying unconfined aquifer (RHO-RE-ST-12P).

Natural recharge to the Rattlesnake Ridge aquifer occurs in the higher elevations surrounding the Pasco Basin to the west, north, and northeast. The flow of groundwater generally is toward the northeast beneath the 200 West Area and possibly east to north beneath the 200 East Area. The aquifer is heterogeneous in composition because the aquifer consists of a basalt flow top and flow bottom, a clayey basalt conglomerate, an epiclastic fluvial-floodplain unit, an air-fall tuff, and a volcaniclastic unit derived from fluvial reworking of the tuff and detrital sediments (RHO-RE-ST-12P). This heterogeneity produces variability of groundwater flow through the aquifer (RHO-RE-ST-12P).

\subsubsection{Contaminant Travel Times}

The travel time of a contaminant from the Hanford Site to the Columbia River is the sum of the time required for the contaminant to travel through the vadose zone to reach the water table and the time required for the contaminant to travel in the groundwater to the Columbia River. Travel time determinations can be based on small- or large-scale field measurements of transport rates or on calculations supported by laboratory scale measurements of the transport parameters. Further discussion of contaminant travel time is contained in Chapter 9.0.

The parameters that affect the travel time in the unconfined aquifer are the following: 
- Distance

- Permeability (or hydraulic conductivity)

- Porosity

- Hydraulic gradient

- Dispersivity

- Retardation

- Heterogeneity (geologic structure).

In addition to these parameters, the vadose zone travel times are further affected by the relative permeability, the moisture content, and the recharge rate. Because of the variability of the sediments, the calculation of travel times based on laboratory derived parameters is considered less accurate than the large scale field measurements. The following sections summarizes the work that has been done in determining travel times in the vadose zone and unconfined aquifer.

5.3.7.1 Vadose Zone. The travel time through the vadose zone depends on the moisture content, which in turn depends on the recharge rate. In the cases of artificial recharge where near saturated conditions have been maintained down to the water table (e.g., 216-B-3 Expansion Ponds), the flow velocity is nearly equal to the saturated hydraulic conductivity of the soil column. This implies a travel time on the order of days. For other cases where the natural recharge is the driving force, the travel time varies considerably depending on the assumed recharge. Several calculations have been done (DOE/EIS-0013) for natural recharge in the 200 East Area ranging from 0.5 centimeter per year to 5.0 centimeters per year. These values were chosen to reflect current and possibly future wetter conditions. The computational results indicated travel times on the order of 900 years to 100 years, respectively, for conservative contaminants. An estimate of travel time as a function of recharge in a 60-meter deep vadose zone has been provided by Gee (Gee et al. 1992).

5.3.7.2 Saturated Zone. More than 20 estimates of travel times from the 200 East and 200 West Areas to the Columbia River have been made by investigators using a number of different methodologies and assumptions. A review of the various travel time estimates has been made over the past 40 years (PNL-6328). These estimates can be classified as being based on one of the following methods:

(1) extrapolation of local groundwater velocity measurements, (2) mathematical methods, and (3) monitoring the movement of contaminant plumes.

The rate and direction of groundwater flow in the vicinity of the 100 Areas are greatly influenced by the level of the Columbia River. This can severely alter the groundwater gradient and even cause flow to be reversed up to 305 meters inland during periods of high water. A similar effect occurs in the 300 Area (WHC-SD-ER-TI-0003).

\subsection{CONTAMINANT PLUME DESCRIPTION [D-10d]}

Ecology regulations [WAC 173-303-806(4)(a)(xx)(D)] require "A description of any plume of contamination that has entered the groundwater from a regulated unit at the time that the application was submitted..." This section contains a description of contaminant plumes identified in the aquifers beneath the Hanford Site. Information provided in this section is relevant to SWMU discussions contained in Chapter 2.0, Section 2.5 and Appendix 2D.

Groundwater contamination currently is monitored under a comprehensive groundwater monitoring and long-tern surveillance program. The results of the monitoring program along with isopleth maps are 
prepared and published anmually (e.g., PNNL-11793). Contaminant plumes are primarily delineated using isopleth maps (i.e., maps with lines connecting points of equal concentration or values).

\subsubsection{Radionuclide Contamination}

Isopleth maps are prepared to track the movement of radiological contaminant plumes (e.g., tritium, gross beta) in the unconfined groundwater flow system beneath the Hanford Site. A study of these plumes can be used to provide an early indication of the rate and direction of contaminant movement. An example of an isopleth map delineating a contamination plume is shown in Figure 5-7 (PNNL-11793). This figure depicts the distribution of average triium concentrations in the unconfined aquifer in 1996. Tritium and iodine-129 are the most widespread radionuclides in the unconfined aquifer (PNNL-11793).

\subsubsection{Nonradioactive Contamination}

The most common nonradioactive inorganic contaminants that have been observed in groundwater are nitrate, cyanide, fluoride, and hexavalent chromium. Among the nonradioactive organic contaminants routinely observed in the groundwater samples are carbon tetrachloride, trichloroethylene, cis-1,2-dichloroethene, and chloroform (PNNL-11793).

Nitrate, like tritium, can be used to define the extent of contamination because nitrate is present in many waste streams at the Hanford Site and is mobile in the groundwater (PNNL-11793). Isopleth maps are prepared to show levels of nitrate concentrations in the groundwater. The configuration of the nitrate plumes can be found in PNNL (1997, Figure S.2). Additional information on nonradioactive contamination is found in groundwater status reports (e.g., PNNL-11793).

It should be noted that the present extent of detectable contamination is primarily the result of past liquid waste discharges to the ground.

\subsection{DETECTION MONITORING PROGRAM [D-10e]}

The final status detection monitoring program is designed to detect the impact of the land-based TSD unit on groundwater quality in the uppermost unconfined aquifer beneath the unit. The final status detection monitoring plan contains details regarding the following:

- Design of the monitoring well network (number and locations of monitoring wells, well construction)

- Frequency of groundwater monitoring

- Type and behavior of chemical parameters that will be used to indicate the presence of groundwater contamination

- Sampling, analysis, and statistical procedures that will be used 
- Methods by which regular determinations of the groundwater flow rate and direction will be determined.

A description of unit-specific monitoring networks is found in the Unit-Specific Portion of this permit application. Final status requirements are applicable to land-based TSD units on incorporation into the HF RCRA Permit (DW Portion).

The following sections provide the necessary data and information to support the implementation of a final status detection monitoring program at land-based TSD units.

\subsubsection{Indicator Parameters, Waste Constituents, Reaction Products to be Monitored [D-10e(1)]}

The monitoring parameters are selected on the basis of suitability to groundwater monitoring at land-based TSD units, and do not necessarily apply to the entire Hanford Facility. The following criteria are considered in the selection of monitoring parameters for each land-based TSD unit:

- Process knowledge and/or use of the TSD unit

- Present in significant quantity in the waste that has been disposed

- Relative mobility and low retardation with respect to groundwater flow, and the stability and persistence in the environment

- Lack of significant natural presence of the parameters in the groundwater

- Ease of detection and minimal sampling and analytical interferences (detectability)

- Usefulness as indicators of other potential contaminants

- Lack of data interpretation problems caused by common laboratory and field contaminants.

5.5.1.1 Dangerous Waste Characterization [D-10e(1)(a)]. A list of the dangerous waste numbers that could be disposed in each land-based TSD unit is included in the HF Part A and in unit-specific permit application, preclosure work plan, closure work plan, closure plan, and closure/postclosure plan documentation. These sources include, to the degree possible, compositions, quantities, and dates of waste disposal, and have, or will, form the basis for the selection of the unit-specific monitoring parameters and constituents.

\subsubsection{Behavior of Constituents [D-10e(1)(b)]. The mobility, stability, and persistence of waste} constituents and their reaction products that have been disposed at a TSD unit are of prime importance in determining the proper unit-specific monitoring parameters and constituents. Constituents that generally are mobile and persistent through the unsaturated zone and into the saturated zone are useful indicators of chemical migration from a waste disposal site.

Parameters such as distribution or sorption coefficients for inorganic (e.g., Freeze and Cherry 1979, pp. 402-408) and organic constituents (Lyman et al. 1982) and chemical solubilities are used in these evaluations. Other important properties that are considered for organic constituents are vapor pressure and 
the Henry's Law constant (used to evaluate to what degree compounds will be partitioned into the aqueous phase and to what degree this phase is likely to migrate as a vapor).

5.5.1.3 Detectability [D-10e(1)(c)]. The detectabilities (the presence or absence) of the groundwater sampling parameters for each land-based TSD unit are to be given in terms of the method detection limit for each of the constituents listed. The practical quantification limits (PQLs) are used to determine if concentration is quantifiable. The PQLs represent the lowest concentrations of analytes in groundwater that can be reliably determined within specified limits of precision and accuracy by the standard analytical methods under routine laboratory operating conditions. Specific requirements are addressed in the unit-specific groundwater monitoring plans.

\subsubsection{Groundwater Monitoring Program [D-10(e)(2)]}

This section describes a comprehensive program to be used during the final status detection monitoring program. The final status detection monitoring system is designed to detect the migration of releases of dangerous waste or dangerous waste constituents within the uppermost unconfined aquifer at compliance points immediately downgradient from potential leak sources. The groundwater will be monitored as required during the active life of the regulated unit (including the closure/postclosure care period).

Groundwater monitoring requirements are contained in Condition II.F. of the HF RCRA Permit (DW Portion).

5.5.2.1 Description of Wells [D-10e(2)(a)]. The basis for locating the monitoring wells around individual land-based TSD units, and the well locations selected to achieve the desired coverage with the minimum number of wells, are discussed in the following sections.

5.5.2.1.1 Background. Groundwater monitoring wells that are required to be installed will be in compliance with the general groundwater monitoring requirements of WAC 173-303-645(8). These wells will yield groundwater samples from the uppermost unconfined aquifer that are representative of the quality of background water immediately upgradient of the unit and the quality of water passing beneath the unit. A determination of background quality may include sampling of wells that are not hydraulically upgradient of the waste management area.

5.5.2.1.2 Design Approach for Monitoring Wells. Tentative locations for monitoring wells are identified along the downgradient sides (point of compliance) of the TSD unit. Initial well locations are determined based on consideration of the interpreted direction of groundwater flow crossing the unit.

The groundwater monitoring system must be capable of yielding groundwater samples for analysis and must consist of the following:

- Monitoring wells installed hydraulically upgradient from the limit of the TSD unit. The number, location, and depths of the wells must be sufficient to yield groundwater samples that are (1) representative of groundwater quality in the uppermost aquifer near the unit and (2) not affected by leakage from the unit 
- Monitoring wells installed hydraulically downgradient at the boundary of the TSD unit. The number, location, and depth of the wells must allow for the detection of dangerous waste or dangerous waste constituents that migrate from the TSD unit to the uppermost aquifer

- All monitoring wells must be cased in a manner that maintains the integrity of the monitoring well borehole. This casing must allow collection of representative groundwater samples and prevent contamination of the samples or the aquifer.

Existing wells might be used as part of the monitoring network provided the wells are: (1) in compliance with WAC 173-160; or (2) meeting criteria as 'equivalent' to a RCRA standard well; or (3) meeting specific DQOs for each monitoring well [Attachment 7 of the HF RCRA Permit (DW portion)]. The reasoning for selection of the location of the individual wells is, or will be, included in unit-specific permit application documentation. Well remediation and abandonment will be accomplished in accordance with WAC 173-160 and the requirements of Condition II.F.2. of the HF RCRA Permit (DW Portion).

5.5.2.1.3 Well Maintenance and Remediation. Monitoring well maintenance, remediation, and abandonment will be performed in accordance with Attachment 6 of the HF RCRA Permit (DW Portion), WAC 173-160, the Tri-Party Agreement, and the HF RCRA Permit (DW Portion). Condition II.F.2. of the HF RCRA Permit (DW Portion) specifically addresses requirements for well remediation and abandonment, involving the following:

- Development of a well inspection plan involving inspection of wells at least once every 5 years; placement of inspection documentation in the Hanford Facility Operating Record (refer to Chapter 12.0, Section 12.1.26)

- Evaluation of wells in accordance with Sections 4.2 through 4.8.3 of Attachment 6 of the HF RCRA Permit (DW Portion) and Attachment 7 of the HF RCRA Permit (DW Portion)

- Provision of written notice to Ecology at least 72 hours before the Permittees remediate (excluding maintenance activities) or abandon any well subject to the HF RCRA Permit

- Construction of wells pursuant to the HF RCRA Permit in compliance with WAC 173-160.

5.5.2.1.4 Monitoring Well Locations and Design. To comply with groundwater monitoring requirements, monitoring wells (i.e., point of compliance) at land-based TSD units are located at intervals along "the hydraulically downgradient limit of the waste management area..." [WAC 173-303-645(6)(a)]. The waste management area is defined as "the limit projected in the horizontal plane of the area on which waste will be placed during the active life of the regulated unit" [WAC 173-303-645(6)(b)]. If the facility contains more than one regulated unit, the waste management area is described by an imaginary line circumscribing the several regulated units. These regulations, therefore, require that monitoring wells be placed as close as reasonably possible to the edge of the regulated unit (i.e., unit boundary). Installation of monitoring wells will be based on the following criteria:

- Satisfy the regulatory requirements for a groundwater monitoring system that consists of a sufficient number of wells installed at appropriate locations and depths to yield groundwater samples that: 
(1) represent the composition of background groundwater that has not been impacted by a TSD unit.

(2) represent the composition of groundwater passing the point of compliance.

- Location of monitoring wells should ensure a high level of confidence that dangerous waste or dangerous constituents migrating from a regulated unit would be reliably detected.

- Wells should be placed in locations that will afford the collection of hydrogeologic information.

5.5.2.2 Equipment Decontamination [D-10e(2)(b)]. All field equipment decontamination and sampling activities will comply with aspects of a health and safety plan and procedures manuals. The procedures are intended to prevent cross-contamination between boreholes during drilling activities. Field equipment decontamination activities will be reported in field documentation.

\subsubsection{Background Values [D-10e(3)]}

Background values are defined as the concentrations of chemical, physical, biological, or radiological constituents, or other characteristics in or of groundwater at a particular point in time and upgradient of a unit, that have not been affected by that unit. Background groundwater quality for detection monitoring can be based on sampling of wells that are not upgradient from the unit if (1) hydrogeologic conditions do not allow the owner or operator to determine what wells are upgradient or (2) sampling at other wells will provide a better indication of background groundwater composition that is as or more representative than that obtained from samples from upgradient wells [WAC 173-303-645(8)(a)(i) and (b) and 40 CFR 264.97(a)(1)]. In this case, baseline values will be determined using historical measurements from each well.

Background or baseline values will be determined for final status detection-level groundwater monitoring parameters. These include general contamination indicator parameters such as specific conductance, $\mathrm{pH}$, total organic carbon, total organic halogen, or heavy metals and site-specific parameters (waste constituents or reaction products) that will provide a reliable indication of the presence of dangerous constituents in groundwater. The site-specific parameters (described in unit-specific permit application documentation) will be selected based on (1) the types, quantities, and concentrations of waste constituents present; (2) the mobility, stability, and persistence of the waste constituents; (3) the detectability of the parameters; and (4) existing data.

Background or baseline values are used to determine whether a RCRA-regulated unit has adversely affected the groundwater quality in the uppermost aquifer beneath the site. This is accomplished by testing for statistically significant changes in concentrations of constituents of interest in a downgradient monitoring well relative to baseline levels. These baseline levels could be obtained from upgradient (or background) wells, and are referred to as interwell (or between-well) comparisons. Alternatively, if baseline values are obtained from historical measurements from that same well, the comparisons are referred to as intrawell (or within-well) comparisons. Requirements for sampling frequency are discussed in Section 5.5.4.5.1. Statistical analyses are presented in Section 5.5.4.7. 
Background data (used for inter-well comparisons) subsequently will be reviewed for seasonal variations, trends, and significant differences among the wells. The background statistics and/or statistical methodology might be modified, if required, to address temporal or spatial variation. Background data also will be reevaluated if changes in groundwater flow direction results in changes in definition of upgradient wells. Additionally, baseline data (used for intra-well comparisons) will be updated periodically (every one to two years) and must be modified for non-detects, seasonal variations, or trend.

\subsubsection{Sampling, Analysis, and Statistical Procedures [D-10e(4)]}

This section provides information on the groundwater sampling, analysis, and statistical evaluation procedures that are proposed for use with the monitoring well system. The choice of an appropriate statistical test depends on the type of monitoring (i.e., detection or compliance) and the nature of the data (e.g., the proportion of values in the data set that are below detection limit) (Figure 5-2). Statistical procedures under final detection or compliance monitoring program status are discussed in Section 5.5.4.7 and Section 5.6.7.4, respectively. As the postclosure monitoring program will be implemented at least 30 years in the future, actual protocols and procedures likely will be equivalent to those cited in this section.

\subsubsection{Sample Collection [D-10e(4)(a)]. The groundwater monitoring system proposed for use on the} Hanford Facility is designed to provide representative groundwater quality data from the uppermost aquifer beneath each land-based TSD unit. Procedures to be followed during the collection of groundwater samples from the network have been developed and will be available to all onsite personnel and to the regulators. These procedures will be consistent with those listed in EPA SW-846.

5.5.4.1.1 Static Water Level Measurements. Before purging or sampling the monitoring well, the static water elevation will be measured, recorded, and remeasured until reproducible results are obtained. The measurements will be taken as depth-to-water from the top of the well casing and the values will be subtracted from the surveyed elevation of the casing to obtain the elevation of the water table. Graduated steel measuring tapes or other approved devices will be used for the measurements.

5.5.4.1.2 Well Purging. Monitoring wells will be purged using a dedicated pump before samples are collected. This action will be taken to obtain groundwater samples that are representative of the formation water, rather than of the stagnant water from the well casing. Groundwater that has occupied the well casing for a long duration often is oxidized and might not be indicative of true formation water.

As a gaideline, high-yielding monitoring wells will be purged until a minimum of three casing volumes have been removed. However, a well will not be considered ready for sample collection until concurrent measurements of $\mathrm{pH}$, specific conductivity, and water temperature have stabilized to at least plus or minus 10 percent over two well volumes pumped (EPA 600/2-85-104). Wells with excessively long purge times could be considered adequately purged when the parameters listed previously have stabilized. Purging of low-yielding monitoring wells (i.e., those that are pumped dry) will consist of removing all standing water. Methods of minimizing or eliminating purge volumes before sampling currently are being evaluated. If the results are favorable, alternate purging and sample-collection techniques will be documented and reflected in revised groundwater monitoring plans.

The pumping rate at each well will be chosen to minimize turbidity and aquifer stress. Generally, the rate of pumping during sampling will be kept below the rate used during well development (EPA 600/2-85-104). 
Water levels, pumping rates, and values of sampling parameters (i.e., $\mathrm{pH}$, specific conductance, and temperature) will be recorded in field logbooks and transferred to a sample groundwater field record form.

Requirements for purgewater management are specified in Condition II.F.1. of the HF RCRA Permit (DW Portion). This condition specifies that purgewater be handled in accordance with requirements of Attachment 5 of the HF RCRA Permit (DW Portion).

5.5.4.1.3 Field Analysis. During well purging and sample withdrawal, field determinations of temperature, turbidity, $\mathrm{pH}$, and specific conductance will be measured and recorded. The stabilization of these parameters will be an indication that well water has been purged and formation water is being sampled. Other methods of determining the presence of formation water (e.g., measuring the concentration of specific ionic species during the well purging process) might be proposed at a future time.

5.5.4.1.4 Sample Withdrawal. After the monitoring well has been purged, water samples will be withdrawn from the well using a dedicated pump. The sample withdrawal rate will be kept to approximately 1 liter per minute as recommended for groundwater sampling when volatile organic compounds are involved (EPA 600/2-85-104).

Samples will be collected and containerized in the order of volatilization sensitivity of the parameters to be analyzed. Samples to be analyzed for volatile organic compounds or other organics will not be filtered.

5.5.4.2 Sample Preservation and Shipment [D-10e(4)(b)]. Sample container and preservation methods that will be used during the groundwater monitoring program are in accordance with EPA SW-846. Measurements of $\mathrm{pH}$ and specific conductance will be taken in the field on unpreserved samples.

Precleaned and prelabeled sample containers will be supplied for each monitoring well and will include the appropriate preservatives. To ensure zero head space, the containers for samples analyzed for volatile organic compounds will be filled to slightly more than full before being capped. Samples typically are collected in the following order:

- Bottles with septum caps (volatiles)

- Unfiltered samples (major-ions, cyanide, semivolatiles)

- Filtered samples (metals).

Immediately after collection, the sample containers will be placed in sealed, insulated coolers packed with ice to cool the ambient temperature to approximately $4^{\circ} \mathrm{C}$. The samples will be transported to the laboratory for arrival within sufficient time to meet holding time requirements. Field parameter record forms and approved sample analysis request forms will be attached to the sealed containers.

5.5.4.3 Analytical Procedures [D-10e(4)(c)]. The laboratory approved for the groundwater monitoring program will use standard laboratory procedures as listed in EPA SW-846 or an alternate equivalent Alternate procedures, when used, will meet the guidelines of EPA SW-846, Chapter 1.0.

Quality control samples, e.g., field duplicates, blanks, and spiked samples, will be collected and analyzed to assess the performance of the sampling program and the analytical laboratories. 
5.5.4.4 Chain of Custody [D-10e(4)(d)]. Chain-of-custody procedures will be followed to ensure the integrity of groundwater samples and to trace the possession and handling of the individual samples from the time of collection through laboratory analyses and data reporting.

Additional quality assurance and quality control methods include sample labels, sample seals, field logbooks, sample analysis request sheets, and laboratory notebooks.

5.5.4.5 Additional Requirements for Compliance Point Monitoring [D-10e(4)(d)]. The following sections discuss additional requirements for compliance point (downgradient) monitoring.

5.5.4.5.1 Sample Frequency [D-10e(4)(e)(i)]. In compliance with regulations, all wells (compliance and background) will be sampled at least semiannually during detection monitoring [WAC 173-303-645(9)(d) and 40 CFR 264.98(d)] and during the active and postclosure period of each land-based TSD unit. The default sampling requirement of taking a sequence of four samples from each well during each sampling interval will be followed, if it is appropriate for the proposed statistical evaluation method (e.g., analysis of variance procedures) . In this case, these four samples will be taken at an interval that ensures, to the greatest extent technically feasible, that an independent sample is obtained. This requirement could be accomplished by reference to the uppermost aquifer's effective porosity, hydraulic conductivity, and hydraulic gradient, and the fate and transport characteristics of the potential contaminants. An alternate sampling procedure approved by Ecology will be used, if the owner/operator finds it to be protective of human health and the environment [EPA 1989b, page 2-8, WAC 173-303-656(8)(g)(ii) and 40 CFR $264.97(\mathrm{~g})(2)]$. Specific sampling requirements will be presented in unit-specific permit application documentation.

5.5.4.5.2 Compliance Point Groundwater Quality Values [D-10e(4)(e)(ii)]. The groundwater quality data obtained from the compliance point monitoring wells will be documented in a form that expresses each groundwater sampling parameter, the analytical value of the concentration in groundwater from the most recent sampling event, the analytical detection limit, and the background (for inter-well comparisons) or baseline (for intra-well comparisons) concentration limit for each parameter. Summary statistics, if needed, will be provided.

5.5.4.6 Annual Determination [D-10e(4)(f)]. Groundwater flow rates and flow direction within the uppermost aquifer will be determined annually for those land-based TSD units being monitored. Average horizontal flow rates and directions could be determined in several ways, e.g.: (1) movement of groundwater plumes over time; (2) in situ measurement devices (e.g., downhole flow meter); or (3) calculated from the groundwater gradient and aquifer properties using the Darcian flow theory:

$$
\mathrm{v}_{\mathrm{h}}=\mathrm{K}_{\mathrm{h}} \mathrm{i}_{\mathrm{h}} / \mathrm{n}_{\mathrm{e}}
$$

where

$$
\begin{aligned}
& \mathrm{v}_{\mathrm{h}}=\text { the horizontal groundwater velocity } \\
& \mathrm{K}_{\mathrm{h}}=\text { the horizontal hydraulic conductivity } \\
& \mathrm{i}_{\mathrm{h}}=\text { the horizontal hydraulic gradient } \\
& \mathrm{n}_{\mathrm{e}}=\text { the effective porosity. }
\end{aligned}
$$

The value of $\mathrm{K}_{\mathrm{h}}$ will be determined from hydraulic property investigations performed on monitoring wells. The average value of $i_{h}$ at the location of each monitoring well will be calculated from the water table 
1 elevations. Effective porosities range between 10 percent and 30 percent (RHO-ST-42). These data will

enable the groundwater flow velocity to be determined in the vicinity of each monitoring well.

\subsubsection{Statistical Determination for Detection Monitoring Program [D-10e(4)(g)]. The concentrations} of constituents of concern in compliance point wells will be compared with background (inter-well comparisons) or with baseline (intra-well comparisons) values semiannually to determine whether there is statistically significant evidence of contamination. Statistical methods appropriate for a final status detection monitoring program will include analysis of variance, tolerance intervals, predication intervals, control charts, test of proportions, or other statistical methods approved by Ecology [WAC 173-303-645(8)(h)]. The type of monitoring, the nature of the data, the proportions of nondetects, and temporal variation are important factors to consider when selecting appropriate statistical methods. The statistical evaluation procedures chosen will be based on the EPA guidance document, Statistical Analysis of Ground-Water Monitoring Data at RCRA Facilities - Interim Final Guidance and its addendum (EPA/530-SW-89-026 and EPA 1992) and Provisional Standard Guide for Developing Appropriate Statistical Approaches for Ground-Water Detection Monitoring Programs developed by American Society for Testing and Materials (ASTM PS64-96). Specifics will be addressed in unit-specific permit application documentation.

The background (or baseline values) and the statistical approach will be evaluated and updated periodically. If changes in groundwater-flow directions result in changes in definition of upgradient well(s) or changes in site conditions, background (or baseline) values will be reestablished. If statistical evaluation methods are no longer effective to achieve the objective because of changing site conditions, a new statistical approach will be proposed in the unit-specific groundwater monitoring plan.

5.5.4.8 Reporting. The results of the statistical evaluation will be reported to Ecology in RCRA quarterly letters and annual groundwater monitoring reports. The statistical results could include a list of groundwater parameters analyzed, detection limits and background or baseline values for each parameter, and the quantified laboratory results. For a particular TSD unit, if statistically significant evidence of contamination is obtained and the owner/operator decide not to make a false-positive claim, the following steps will be taken.

- Ecology will be notified in writing within 7 days of the finding with a report indicating which indicator parameters and or constituents have shown a statistically significant increase over the background or baseline values.

- A determination will be made as to whether dangerous constituents are present, and if so, in what concentration;

- The owner/operator may resample within one month and repeat the analysis for those compounds detected in the above;

- The dangerous constituents detected either in the initial analysis or in the second confirmation analysis will form the basis for compliance monitoring.

- Within 90 days or time agreed to in writing by Ecology, a plan will be submitted to Ecology to establish a compliance monitoring program meeting the requirements of WAC 173-303-645(10) or 40 CFR 264.99. 
In case of a false-positive claim, the following will be taken:

- Notify Ecology in writing within 7 days of the finding (i.e., exceedance) and indicate that a false-positive claim will be made;

- Submit a report to Ecology within 90 days or time agreed to in writing.by Ecology. This report should demonstrate that a source other than the regulated unit caused the contamination or that the contamination resulted from an error in sampling, analysis, or evaluation or natural variation in groundwater chemistry;

- Submit an application for a permit modification, if necessary, to make any appropriate changes to the detection-monitoring program within 90 days or time agreed to in writing by Ecology;

- Continue to monitor in accordance with the detection-monitoring program;

- Submit an application for a permit modification, if the detection monitoring program no longer satisfies the requirements [of WAC 173-303-645(9)], to make any appropriate changes to the program within 90 days or time agreed to in writing by Ecology.

Groundwater monitoring records will be retained in the Hanford Facility Operating Record as discussed in Chapter 12.0, Section 12.1.26.

\subsection{COMPLIANCE MONITORING PROGRAM [D-10f]}

A compliance monitoring program will be established for a land-based TSD unit if groundwater sampling during detection-level monitoring reveals statistically significant evidence of contamination (confirmed by verification sampling) at the point of compliance. In a compliance monitoring program, the monitoring objective is to determine whether groundwater protection standards have been exceeded. This is accomplished by comparing the concentration of a constituent of concern to groundwater protection standards such as maximum concentration limit and alternate concentration limit; background; or applicable, relevant, and appropriate requirements.

\subsubsection{Waste Description [D-10f(1)]}

Waste that could be managed by TSD units is included in the HF Part A. If required, additional information will be provided on (1) the results of any direct sampling of the waste, (2) a list of expected waste constituents, and (3) an estimate of the composition and physical properties of any immiscible fluids that could be expected to have been derived from the waste.

\subsubsection{Characterization of Contaminated Groundwater [D-10f(2)]}

If a compliance-level monitoring program at a given TSD unit is considered necessary, a complete characterization of groundwater will be provided in which an increase in dangerous chemicals above appropriate reference levels is indicated. In general, the characterization of groundwater could include (I) concentrations of each constituent detected in 40 CFR 264, Appendix IX, (2) concentrations of major 
anions and cations, and/or (3) concentrations of any other appropriate constituents [e.g., Table I of

2 WAC 173-303-645(5)]. However, specific requirements will be proposed in unit-specific permit application

3 documentation. Disposal of purgewater is determined by analytical results of the groundwater. If the

4 analytical results exceed the criteria established in Attachment 5 of the HF RCRA Permit (DW Portion), the

5 purgewater is contained. All other purgewater is returned to the ground or as specified in Attachment 5 of the

6 HF RCRA Permit (DW Portion) and complies with Permit Condition II.F.

\subsubsection{Dangerous Constituents to be Monitored [D-10f(3)]}

If compliance monitoring is required, the DQO process will be used to guide the selection of constituents of concern, sampling and analysis, statistical methods, etc. If other groundwater constituents indicative of migrating waste products are identified, the list of groundwater parameters will be revised to include such constituents.

\subsubsection{Concentration Limits [D-10f(4)]}

With enactment of compliance-level monitoring, maximum concentration limits will be identified for applicable groundwater monitoring parameters listed in Table 1 of WAC 173-303-645, and other appropriate constituents for the specific TSD unit. Alternate concentration limits will be proposed after considering the observed concentrations of chemical constituents in the groundwater that might have been derived from the regulated unit in question. The Hanford Site groundwater background (DOE/RL-96-61), and other standards that are applicable, relevant, and appropriate requirements, will be considered when proposing an alternate concentration limit. Concentration limits will be proposed in unit-specific permit application documentation.

If, during compliance-level monitoring, the reference concentration limits for a given groundwater parameter or parameters are significantly exceeded, a corrective action program will be established (Section 5.7).

\subsubsection{Groundwater Monitoring System [D-10f(6)]}

The compliance-level groundwater monitoring system will be designed to determine whether groundwater protection standards have been exceeded. Thus, the compliance-level groundwater monitoring system will comply with WAC 173-303-645(10) or agreement for a compliance monitoring program.

5.6.5.1 Description of Wells [D-10f(6)(a)]. The system design will consist of those wells installed uncer the detection-level monitoring program and any additional wells that are determined to be required after assessing the detection efficiency of the present well network.

5.6.5.2 Representative Samples [D-10f(6)(b)]. The compliance monitoring system will be designed to provide groundwater samples that are representative of groundwater composition at the point of compliance.

5.6.5.3 Location of Background Monitoring Wells that Are Not Upgradient [D-10f(6)(c)]. Background groundwater composition could be based on samples from wells that are not upgradient from the TSD unit. 
The justification of well locations for unit background water quality is addressed in unit-specific permit application documentation.

\subsubsection{Background Values [D-10f(7)]}

Background concentration values, if appropriate, will be proposed for each groundwater monitoring parameter identified for the compliance-level monitoring program. The exact sampling periods, frequencies, and statistical methods used to establish the background values will be presented in unit-specific permit application documentation. Background values will be established in conjunction with the Hanford Sitewide background study (DOE/RL-96-61). Background will be established for additional constituents identified in the Appendix IX analysis, if necessary. It is anticipated that those procedures and techniques used to establish background conditions under the final status detection-level monitoring program will be applied.

\subsubsection{Sampling, Analysis, and Statistical Procedures [D-10f(8)]}

A proposed sampling and analysis plan, including procedures for sample collection, sample preservation and shipment, analytical methods, and chain-of-custody controls, will be prepared if compliance-level monitoring becomes necessary. The basic information for sample collection, sample preservation and shipment, analytical methods, and chain-of-custody procedures will not likely change from the proposed plans submitted under the detection-level monitoring program (Section 5.5). To comply with WAC 173-303-645(10)(f), the compliance-level monitoring wells will be sampled at least semiannually for the specified groundwater parameters and waste constituents. If verified groundwater monitoring results indicate that appropriate groundwater protection standards (e.g., maximum concentration limit or alternate concentration limit; or applicable, relevant, and appropriate requirements) are exceeded at any monitoring well along the line of compliance, written notification will be made to Ecology within 7 days of the finding. An application for a permit modification to establish a corrective action program (Section 5.7) will be submitted within 90 days [WAC 173-303-645(10)(g)(I)(ii)] or time agreed to in writing by Ecology. In the case of a false positive claim, the owner/operator will notify Ecology within 7 days in accordance with WAC 173-303-645(10)(I)(1).

5.6.7.1 Sample Collection [D-10f(8)(a)]. This information will not likely change from the proposed plans submitted under the detection-level monitoring program (Section 5.5.4). The number of samples collected will be specified in the unit-specific documentation (e.g., groundwater monitoring plan).

5.6.7.2 Additional Requirements for Compliance Point Monitoring [D-10f(8)(e)]. Under compliance monitoring, additional activities will be conducted, if necessary, to provide a more protective monitoring program.

5.6.7.2.1 Sample Frequency [D-10f(8)(e)(I))]. Under compliance monitoring, downgradient compliance wells will be sampled semiannually [WAC 173-303-645(10)(f)].

\subsection{Compliance Point Groundwater Quality Values [D-10f(8)(e)(iii)]. Analytical} groundwater quality data will be prepared in an appropriate form for full statistical analysis. These data will exist primarily in tabular form and will consist of raw data from each individual sample obtained during each sampling event. The presentation of the statistical evaluation of the data will depend on the monitoring objectives (Section 5.6.4). 
1 5.6.7.3 Annual Determination of Hydraulic Gradient [D-10f(8)(f)]. Under compliance monitoring, the 2 hydraulic gradient will be determined anmually and the efficiency of the monitoring well network will be 3 addressed. If warranted, additional monitoring wells will be installed.

5.6.7.4 Statistical Determination for Compliance Monitoring Program [D-10f(8)(g)]. Statistical evaluation of groundwater monitoring data will comply with requirements set forth in the WAC 173-303-645 (8)(h) final status regulations. Procedures outlined in the following EPA technical guidance documents will be followed:

- Statistical Analysis of Groundwater Monitoring Data at RCRA Facilities: Interim Final Guidance (EPA/530-SW-89-026)

- Statistical Analysis of Groundwater Monitoring Data at RCRA Facilities - Draft Addendum to Interim Final Guidance (EPA 1992).

- Provisional Standard Guide for Developing Appropriate Statistical Approaches for Ground-Water Detection Monitoring Programs (ASTM PS64-96).

For a compliance-level groundwater monitoring program, the choice of an appropriate statistical method depends on the type of groundwater concentration limit and whether the compliance well exceeds the concentration limit. Appropriate statistical methods include, but are not limited to, tolerance limit, prediction limit, and the Combined Shewhart-CUSUM control chart. Specifics will be proposed in unit-specific groundwater monitoring documentation (e.g., groundwater monitoring plan).

Groundwater monitoring records will be retained in the Hanford Facility Operating Record as discussed in Chapter 12.0, Section 12.1.26.

\subsection{CORRECTIVE ACTION PROGRAM [D-10g]}

If, at the point of compliance, dangerous constituents are measured in the groundwater at concentrations that exceed accepted groundwater protection standards, sufficient data, supporting information, and analyses will be provided to establish a corrective action program.

A description of the groundwater monitoring plan that will be used to assess the effectiveness of the corrective action measures will be submitted. This groundwater monitoring plan could be similar in scope to a compliance- level monitoring program developed under Section 5.6 and will include all relevant information pertaining to the location and description of monitoring wells, groundwater sampling and analysis plans, statistical methods, and quality assurance and quality control procedures [WAC 173-303-645(11)(d)].

The concentrations established in the Hanford Sitewide background study, in conjunction with local background concentrations and applicable risk-based standards, will determine groundwater protection standards for each land-based TSD unit. This will reduce the time and costs currently being expended for sampling unit-specific background wells, and will further benefit cleanup efforts by the uniform application of cleanup standards across the Hanford Site. The Hanford Sitewide groundwater background study is discussed in DOE/RL-96-61. 
This page intentionally left blank. 


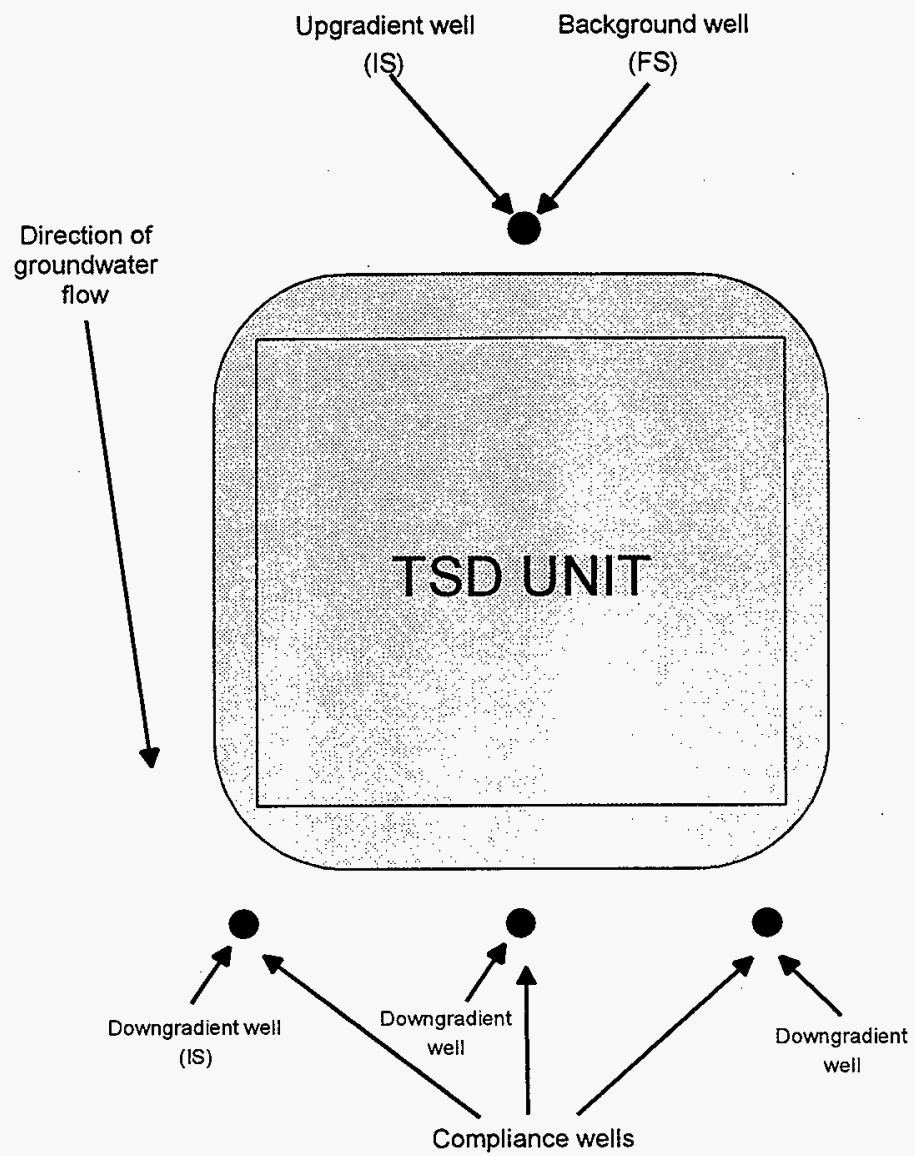

Waste management area.

(FS)

[The limit projected in the horizontal plane of the area on which waste will be placed during the active life of the regulated unit (WAC 173-303-645(6)(b).]

IS = interim status

FS $=$ Final status

TR960606:F51_wI:ds4

Figure 5-1. Generalized Configuration for a Detection Monitoring Groundwater Well System. 


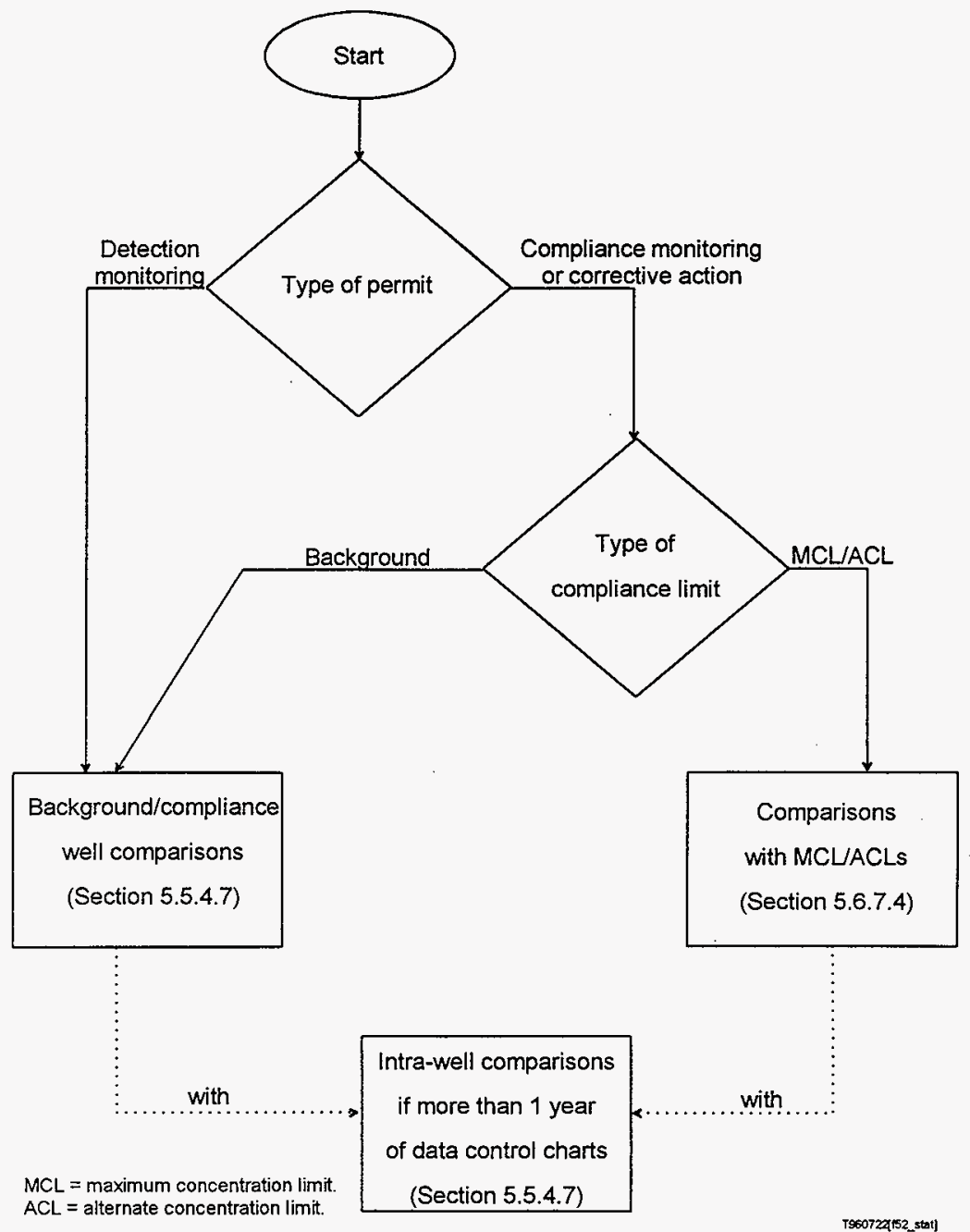

$M C L=$ maximum concentration limit. $\mathrm{ACL}=$ alternate concentration limit.

T960724152_stat]

Figure 5-2. Flow Chart for Selection of Appropriate Statistical Method Used for Data Interpretation. 
DOE/RL-91-28, Rev. 4

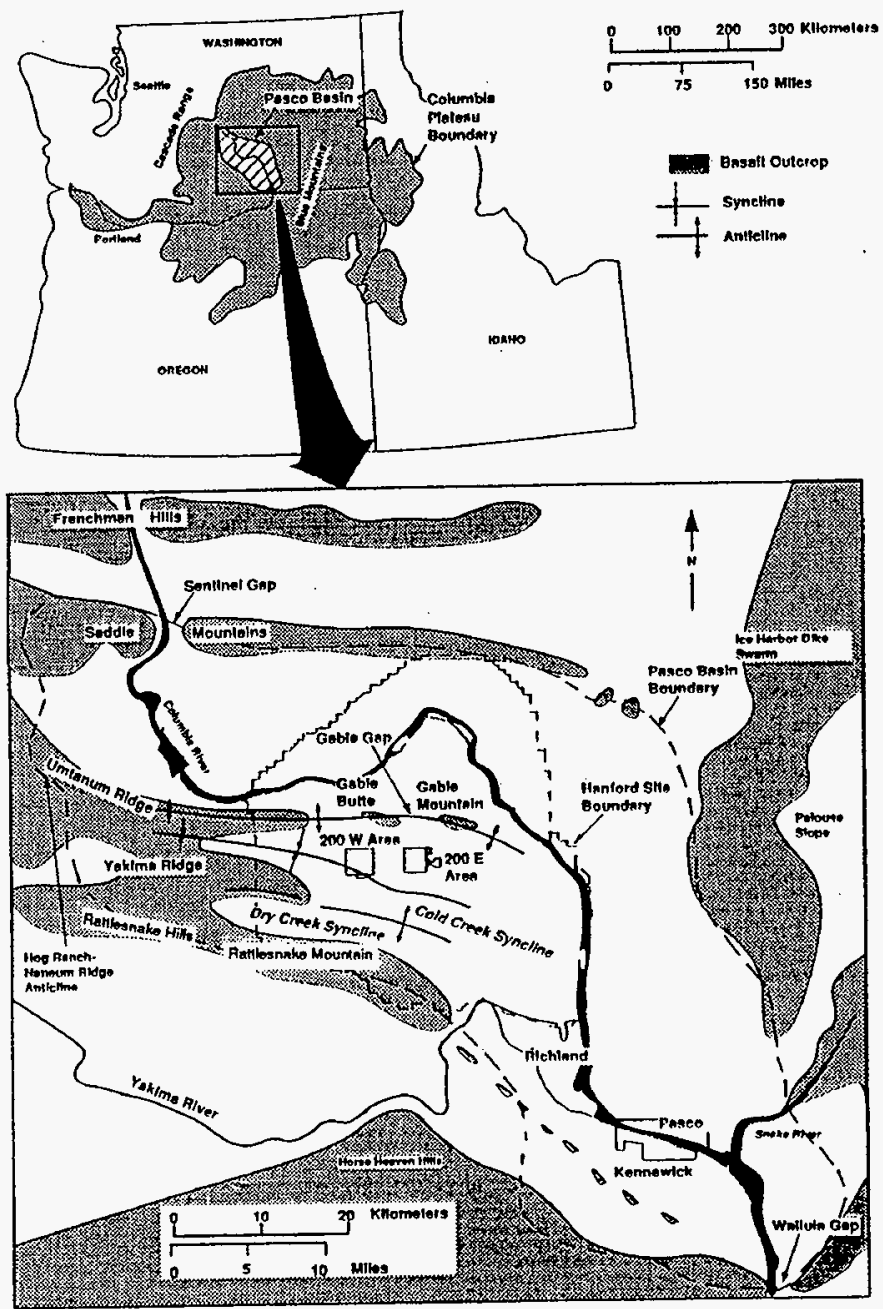

39103001.5

Figure 5-3. Location of Bounding Structures of the Pasco Basin. 
әฺ! projur

\section{8*1008016E $22 \angle 0961$}

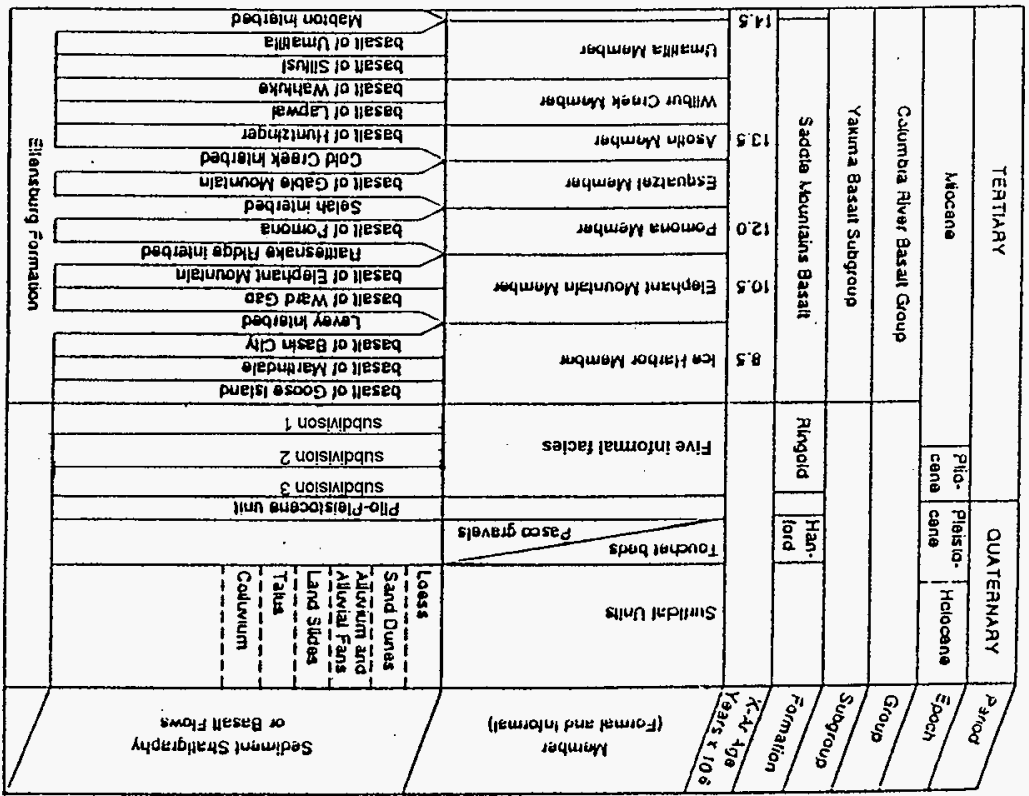



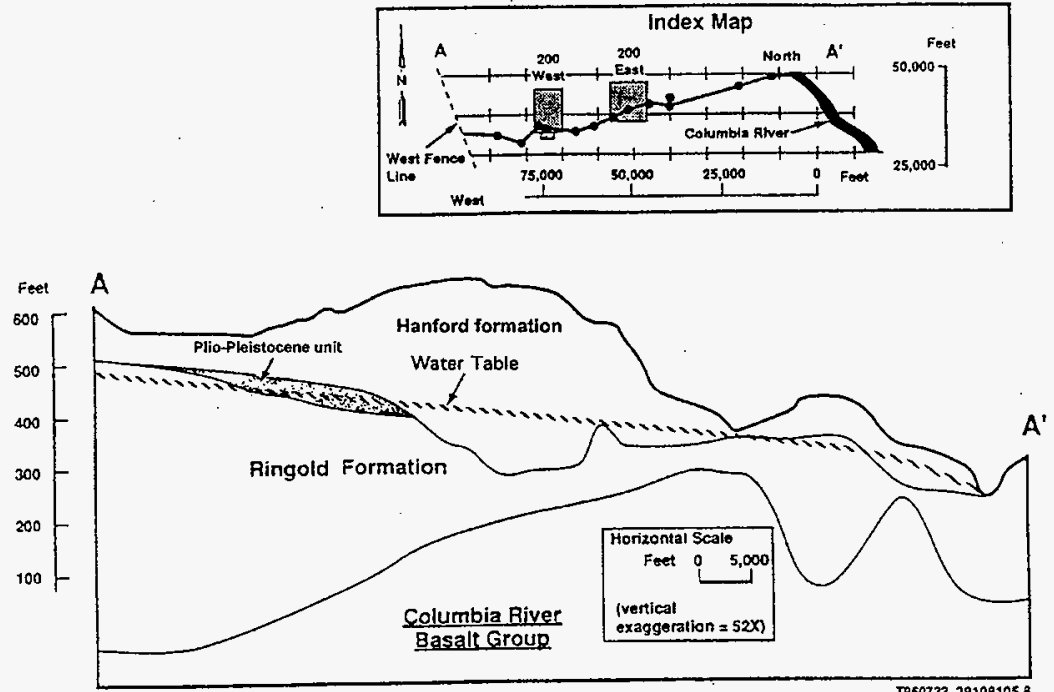

T960722 09108105.8

Figure 5-5. Generalized Geologic Cross-Section Through the Hanford Site (RHO-ST-23). 
DOERL-91-28, Rev. 4

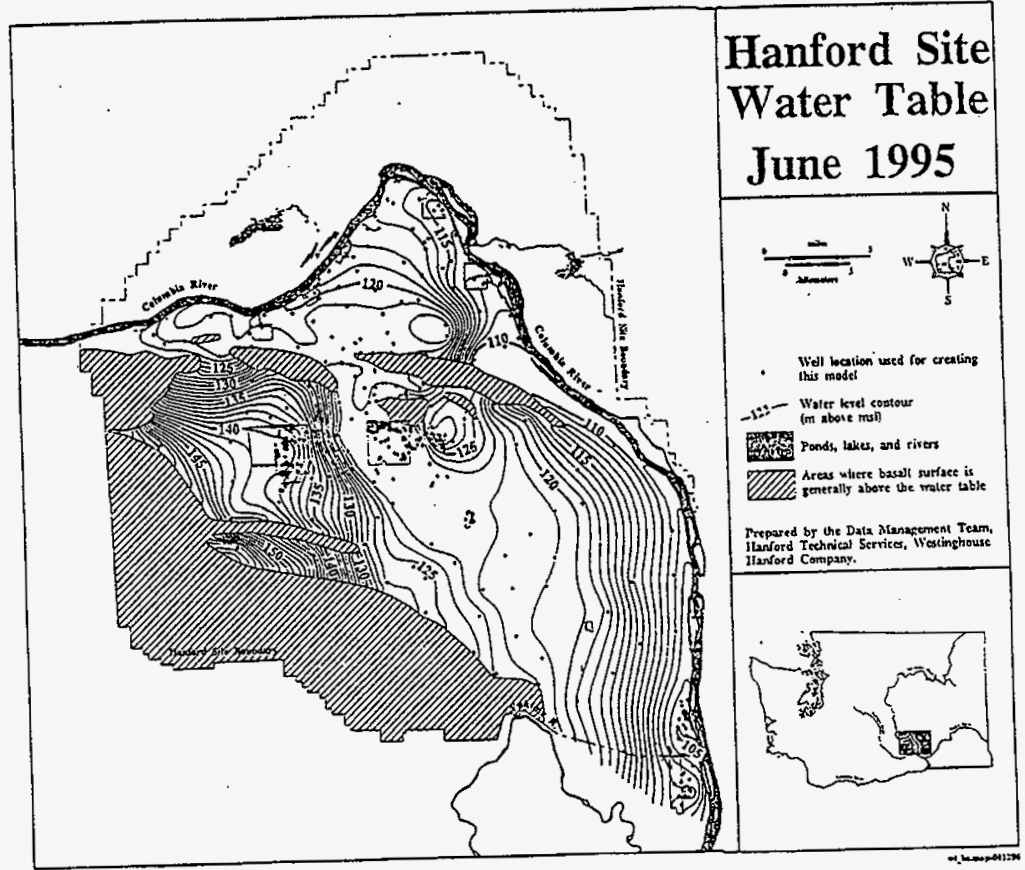

Figure 5-6. Water Table Map of the Hanford Site. 


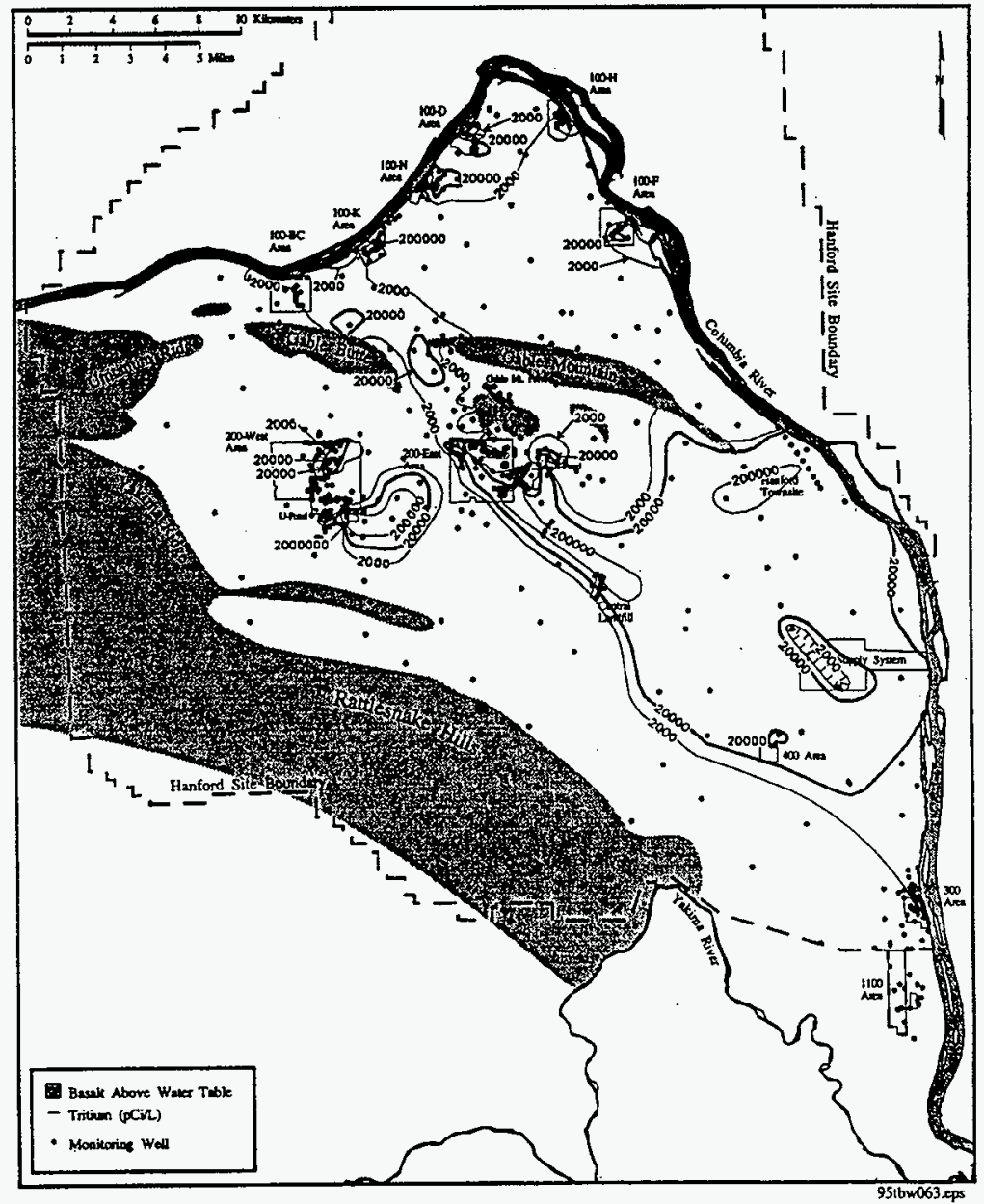

Tritium at Hanford.

Figure 5-7. Distribution of Tritium on the Hanford Site (PNNL-11139). 


\section{CONTENTS}

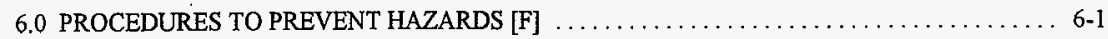

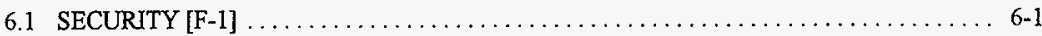

6.1.1 Security Procedures and Equipment $[\mathrm{F}-1 \mathrm{a}] \ldots \ldots \ldots \ldots \ldots \ldots \ldots \ldots \ldots \ldots, 6-1$

6.1 .2 Waiver $[\mathrm{F}-1 \mathrm{~b}] \ldots \ldots \ldots \ldots \ldots \ldots \ldots \ldots \ldots \ldots \ldots \ldots \ldots \ldots \ldots \ldots \ldots \ldots \ldots \ldots, 6,2$

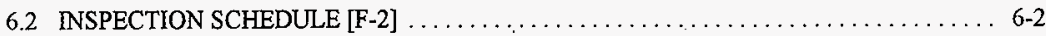

6.2 .1 General Inspection Requirements $[\mathrm{F}-2 \mathrm{a}] \ldots \ldots \ldots \ldots \ldots \ldots \ldots \ldots \ldots \ldots \ldots, 6-2$

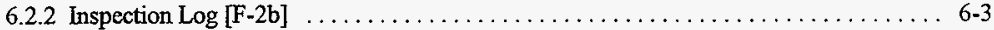

6.2.3 Schedule for Remedial Action for Problems Revealed $[\mathrm{F}-2 \mathrm{c}] \ldots \ldots \ldots \ldots \ldots \ldots \ldots$ 6-3

6.2.4 Specific Process or Waste Type Inspection Requirements [F-2d] $\ldots \ldots \ldots \ldots \ldots \ldots$ 6-3

6.3 PREPAREDNESS AND PREVENTION REQUTREMENTS [F-3] $\ldots \ldots \ldots \ldots \ldots \ldots \ldots, 6-3$

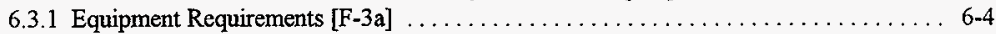

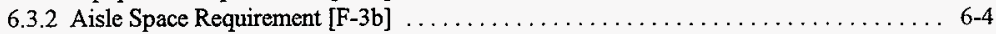

6.4 PREVENTIVE PROCEDURES, STRUCTURES, AND EQUIPMENT [F-4] $\ldots \ldots \ldots \ldots 6.4$

6.5 PREVENTION OF REACTION OF IGNITABLE, REACTIVE, AND/OR

INCOMPATIBLE WASTES $[\mathrm{F}-5] \ldots \ldots \ldots \ldots \ldots \ldots \ldots \ldots \ldots \ldots \ldots \ldots \ldots, 6-4$ 
DOE/RL-91-28, Rev. 4

05/98

This page intentionally left blank. 


\subsection{PROCEDURES TO PREVENT HAZARDS [F]}

This chapter addresses the provisions of Section $\mathrm{F}$ of Ecology's permit application guidance (Ecology 1987 and 1996), and includes a discussion of the following topics:

- Security

- Inspection schedule

- Preparedness and prevention requirements

- Preventive procedures, structures, and equipment

- Prevention of reaction of ignitable, reactive, and/or incompatible wastes.

Also addressed are provisions contained in Conditions II.M. (Security) and II.O. (General Inspection Requirements) of the HF RCRA Permit (DW Portion).

Procedures to prevent hazards for individual TSD units are included in the Unit-Specific Portion of this permit application or, if appropriate; in unit-specific preclosure work plan, closure work plan, closure plan, closure/postclosure plan, or postclosure permit application documentation.

\subsection{SECURITY [F-1]}

The following sections describe the security measures, equipment, and warning signs used to control entry to the Hanford Facility and to meet Condition II.M. of the HF RCRA Permit (DW Portion). Security information for individual TSD units is provided in the Unit-Specific Portion of this permit application or, if appropriate, in unit-specific preclosure work plan, closure work plan, closure plan, closure/postclosure plan, or postclosure permit application documentation.

\subsubsection{Security Procedures and Equipment [F-1a]}

The section describes the 24-hour surveillance system, warning signs, and barriers used to provide security and control access to the Hanford Facility. The entire Hanford Facility is a controlled access area. The Hanford Facility maintains around-the-clock surveillance for protection of government property, classified information, and special nuclear materials. The Hanford Patrol maintains a continuous presence of protective force personnel to provide additional security.

The majority of TSD units are located within, or in the vicinity of, the 200 Areas (refer to Chapter 1.0, Table 1-1, Appendix 2A). Staffed barricades are maintained around the clock at checkpoints on vehicular access roads leading to these areas (Yakima, Wye, and Rattlesnake Barricades; Drawing H-6-958 in Appendix 2A). All personnel accessing locations on the Hanford Site (except for publicly accessible locations) must have a U.S. Department of Energy-issued security identification badge indicating the appropriate authorization. Personnel also could be subject to a random search of items carried into or out of the Hanford Site. Additional means to bar entry or control access (c.g., fences, locked entry doors) are discussed in the Unit-Specific Portion of this permit application or, if appropriate, in unit-specific preclosure work plan, closure work plan, closure plan, closure/postclosure plan, or postclosure permit application documentation. 
Signs are, or will be, posted at area boundaries within the Hanford Site stating "NO TRESPASSING. SECURITY BADGES REQUIRED BEYOND THIS POINT. AUTHORIZED VEHICLES ONLY. PUBLIC ACCESS PROHIBITED" (or an equivalent legend). In addition, warning signs stating "DANGER--UNAUTHORIZED PERSONNEL KEEP OUT" (or an equivalent legend) are, or will be, posted at TSD units within the Hanford Facility. These signs are, or will be, written in English, legible from a distance of 7.6 meters, and visible from all angles of approach.

\subsubsection{Waiver $[\mathrm{F}-1 \mathrm{~b}]$}

Waivers of the security procedures and equipment requirements for the Hanford Facility currently are not requested.

\subsection{INSPECTION SCHEDULE [F-2]}

This section addresses the general inspection requirements for the Hanford Facility. The TSD unit-specific inspection activities are addressed in the Unit-Specific Portion of this permit application or, if appropriate, in unit-specific preclosure work plan, closure work plan, closure plan, closure/postclosure plan, or postclosure permit application documentation.

\subsubsection{General Inspection Requirements [F-2a]}

General inspection requirements for the Hanford Facility are specified in Condition II.O. of the HF RCRA Permit (DW Portion). This condition requires the following:

- Facility inspections to be conducted in accordance with the provisions of WAC 173-303-320(2)

- Inspections of the 100,200 East, 200 West, 300, 400, and 1100 Areas to be conducted annually

- Inspection of the banks of the Columbia River, contained within the Hanford Facility boundary, to be conducted two times per year (i.e., one at the low water mark of the year, and one at a time chosen by the Permittees)

- Visual inspection for maifunctions, deterioration, operator errors, and discharges that might cause or lead to the release of dangerous waste constituents to the environment or that threaten human health

- Notification to Ecology at least 7 days before conducting these inspections to allow Ecology representatives to be present during the inspection

- Remedial action to be taken, if required, in accordance with a schedule agreed to by Ecology. 


\subsubsection{Inspection Log [F-2b]}

Documentation of the inspections conducted in accordance with Condition II.O. of the HF RCRA Permit (DW Portion) is placed in the Hanford Facility Operating Record, General Information File (refer to Chapter 12.0, Section 12.1.30).

\subsubsection{Schedule for Remedial Action for Problems Revealed [F-2c]}

In accordance with Condition II.O of the HF RCRA Permit (DW Portion), remedial action schedules will be developed for any problems discovered during a Hanford Facility inspection. These schedules will be agreed to by Ecology.

\subsubsection{Specific Process or Waste Type Inspection Requirements [F-2d]}

As noted in Chapter 1.0, Table 1-1, the Hanford Facility includes TSD units with container handling capabilities, tank systems, surface impoundments, containment buildings, landfills, waste piles, and miscellaneous units. Inspections requirements for each of the TSD units are addressed in the Unit-Specific Portion of this permit application or, if appropriate, in unit-specific preclosure work plan, closure work plan, closure plan, closure/postclosure plan, or postclosure permit application documentation.

\subsection{PREPAREDNESS AND PREVENTION REQUIREMENTS [F-3]}

The emergency preparedness and prevention measures taken for the Hanford Facility are described in this section. Most of the Hanford Facility 'operating' TSD units are equipped with internal communication systems to relay emergency or other information to unit personnel. The internal communication systems include telephones, various alarm systems, and hand-held or vehicle two-way radios. Alarm systems exist at various locations throughout the Hanford Facility to allow personnel to respond appropriately to various emergency situations, including the following: building evacuations, take-cover events, and fire and/or explosion. Telephones are located throughout the Hanford Facility and provide both internal and external communication. In addition, the following external communication systems are available for notifying persons assigned to emergency response organizations:

- Fire alarm pull boxes and fire sprinkler flow monitoring devices--connected to a system monitored around the clock by the Hanford Fire Department

- Emergency telephone numbers 911 (or 375-2400 for PNNL facilities)--on notification, the Hanford Patrol Operations Center notifies and/or dispatches required emergency responders

- Crash alarm telephone system--consists of selected telephones that are disassociated from the regular system and are connected automatically to control stations

- Two-way radio system--consists of hand-held or vehicle radios; the system accesses the Hanford Facility emergency network and can summon the Hanford Fire Department, Hanford Patrol, and/or any other assistance needed to deal with emergencies. 


\subsubsection{Equipment Requirements [F-3a]}

Equipment requirements are listed in Attachment 4 of the HF RCRA Permit (DW Portion). Unit-specific equipment requirements are listed in the Unit-Specific Portion of the permit application.

\subsubsection{Aisle Space Requirement [F-3b]}

Aisle space requirements for 'operating' TSD units are addressed in the Unit-Specific Portion of this permit application.

\subsection{PREVENTIVE PROCEDURES, STRUCTURES, AND EQUIPMENT [F-4]}

Preventive procedures are in place to ensure that unloading activities are conducted in a safe manner and that run-off of liquid, if spilled during waste unloading operations, is contained and disposed of properly. In those areas of TSD units where significant risk of exposure to dangerous and/or mixed waste exists, personnel are required to wear protective suits and/or respiratory devices, depending on the specific hazard. Provisions are in place at specific TSD units to ensure that backup power is provided for equipment critical to operations. Preventive measures information specific to TSD units is contained in the Unit-Specific Portion of this permit application or, if appropriate, in unit-specific preclosure work plan, closure work plan, closure plan, closure/postclosure plan, or postclosure permit application documentation.

Description of actions designed to control and mitigate effects to human health and the environment for any spill or release between TSD unit boundaries (i.e., onsite transportation) are described in Attachment 4 of the HF RCRA Permit (DW Portion) and where appropriate in the Unit-Specific Portion of this permit application.

\subsection{PREVENTION OF REACTION OF IGNITABLE, REACTIVE, AND/OR INCOMPATIBLE WASTES [F-5]}

Procedures and precautions to prevent the reaction of ignitable and reactive waste at 'operating' TSD units are described in the Unit-Specific Portion of this permit application. Procedures and precautions to prevent the reaction of incompatible waste are described in Attachment 4 of the HF RCRA Permit (DW Portion). 


\section{CONTENTS}

47.0 CONTINGENCY PLAN [G]

$7-1$

5 
This page intentionally left blank. 


\subsection{CONTINGENCY PLAN [G]}

This chapter addresses the provisions identified in Section $\mathrm{G}$ of Ecology's permit application guidance (Ecology 1987 and 1996). The WAC 173-303 requirements for a contingency plan are satisfied by the Hanford Emergency Response Plan [Attachment 4 of the HF RCRA Permit (DW Portion)], together with each TSD unit-specific contingency plan contained in the Unit-Specific Portion of this permit application. Contingency information, if appropriate, also could be contained in preclosure work plan, closure work plan, closure plan, closure/postclosure plan, or postclosure permit application documentation.

The Hanford Emergency Response Plan includes response discussions pertaining to certain releases of hazardous substances as defined in WAC 173-303-040. Releases of hazardous substances that threaten human health and the environment resulting from transportation activities occurring on the Hanford Facility are subject to the HF RCRA Permit (DW Portion) (refer to Condition II.A. and to Permit Attachment 3, the Permit Applicability Matrix).

A matrix describing which portions of the Hanford Emergency Response Plan meet contingency planning requirements is included as an appendix to the Hanford Emergency Response Plan. A matrix will also be included for operating units in the TSD Unit-Specific Portion of this permit application.

The emergency preparedness documentation approach described above will also be used for dangerous and mixed waste management activities subject to WAC 173-303-350 at the Hanford Facility. 
DOE/RL-91-28, Rev. 4

05/98

This page intentionally left blank. 


\section{CONTENTS}

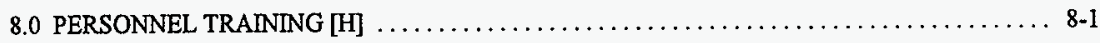

8.1 GENERAL FACILITY TRAINING $\ldots \ldots \ldots \ldots \ldots \ldots \ldots \ldots \ldots \ldots \ldots \ldots \ldots, 1$

8.2 TREATMENT, STORAGE, AND/OR DISPOSAL UNIT-SPECIFIC TRAINING $\ldots \ldots \ldots \ldots 8$-1

8.3 TRAINING RECORDS $\ldots \ldots \ldots \ldots \ldots \ldots \ldots \ldots \ldots \ldots \ldots \ldots \ldots \ldots \ldots \ldots \ldots \ldots, 2$

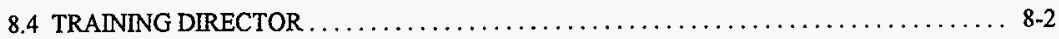

12

13

14 
3

4

This page intentionally left blank. 


\subsection{PERSONNEL TRAINING [H]}

\subsection{GENERAL FACILITY TRAINING}

Condition II.C. 2. of the HF RCRA Permit (DW Portion) requires Hanford Facility personnel to receive general facility training within 6 months of hire. This training provides an orientation on dangerous waste management activities being conducted on the Hanford Facility and includes the following:

- Description of emergency signals and appropriate personnel response

- Identification of contacts for information regarding dangerous waste management activities

- Introduction to waste minimization concepts

- Identification of contact(s) for emergencies involving dangerous waste

- Familiarization with applicable contingency planning requirements.

Each Permittee has access to a general facility training module that meets the requirements listed for Condition II.C.2. of the HF RCRA Permit (DW Portion).

Condition II.C.4. of the HF RCRA Permit (DW Portion) requires the Permittees to provide the necessary training to non-Facility personnel (i.e., visitors, subcontractors) as appropriate for the locations and activities undertaken. At a minimum, this training describes dangerous waste management hazards on the Hanford Facility.

\subsection{TREATMENT, STORAGE, AND/OR DISPOSAL UNIT-SPECIFIC TRAINING}

The training programs for individual TSD units can be found in the Unit-Specific Portion of this permit application or, if appropriate, in preclosure work plan, closure work plan, closure plan, closure/postclosure plan, or postclosure permit application documentation. These programs ensure that personnel training is conducted as required by WAC 173-303-330, as specified in Condition II.C. 1. of the HF RCRA Permit (DW Portion). The training programs contribute to the assurance that TSD units are operated and maintained in accordance with requirements of the EPA, Ecology, and DOE-RL.

The training programs are overseen by the DOE-RL and prepare personnel to operate and maintain Hanford Facility TSD units in a safe, efficient, and environmentally sound manner. In addition to preparing personnel to operate and maintain the TSD units under normal conditions, the programs ensure that personnel are prepared to respond in a prompt and effective manner should offnormal or emergency conditions occur. 
1 Emergency response training is consistent with emergency responses outlined in Hanford Emergency

2 Response Plan [Attachment 4 of the HF RCRA Permit (DW Portion)] and in descriptions of actions outlined

3 in the Unit-Specific Portion of this permit application or, if appropriate, in preclosure work plan, closure

\subsection{TRAINING RECORDS}

As specified in Condition II.C.1. of the HF RCRA Permit (DW Portion), each Hanford Facility Permittee maintains documentation in accordance with WAC 173-303-330(2) and (3). Training records could be maintained in hard copy form or by using electronic data storage. At a minimum, training records will consist of course attendance rosters correlating the training received with the personnel who were in attendance. Training records are maintained in accordance with the requirements of the Privacy Act of 1974. Training records for personnel are available for inspection purposes through 59 FR 17091, which gives federal, state, and local government officers 'routine use' access to training records where a regulatory program being implemented is applicable to a DOE-RL or contractor program. Further discussion of the maintenance of Hanford Facility and TSD unit-specific personnel training records is included in Chapter 12.0, Section 12.1.20.

\subsection{TRAINING DIRECTOR}

One person does not function as the training director on the Hanford Facility. A TSD unit manager has overall responsibility for all training required by WAC 173-303-330 and Condition II.C. of the HF RCRA Permit (DW Portion) at the TSD unit under this manager's control. To meet requirements of a training director in WAC 173-303-330(1)(a), the position is shared among TSD unit personnel, central training organization personnel, and other support organization personnel. A TSD unit manager can access training resources and experts from many different areas on a variety of subject matters rather than relying on the knowledge of a limited number of persons. This shared responsibility ensures the identification of the appropriate training requirements and that the Hanford Facility dangerous waste training programs for each Permittee meet all applicable dangerous waste management requirements. 


\section{CONTENTS}

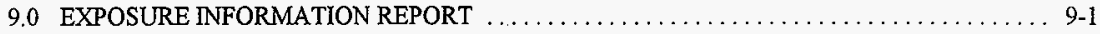

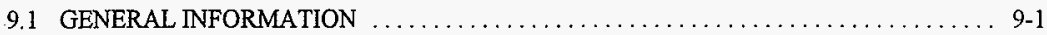

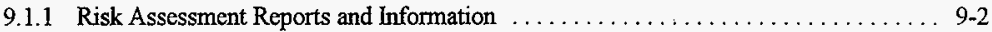

9.1.1.1 Hanford Facility . . . . . . . . . . . . . . . . . . . . . . .

9.1.1.2 Surface Impoundment and/or Landfill TSD Units . . . . . . . . . . $9-2$

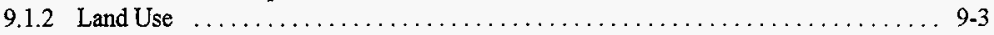

9.1.3 Aerial Photographs . . . . . . . . . . . . . . . . . . . . . . . . . . .

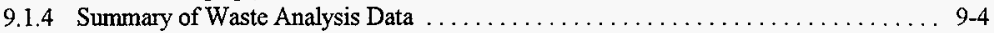

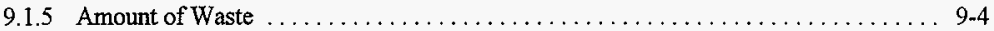

9.1.6 Records Produced by Environmental or Health Agencies . . . . . . . . . . . 9-5

9.2 PATHWAY-SPECIFIC INFORMATION $\ldots \ldots \ldots \ldots \ldots \ldots \ldots \ldots \ldots \ldots \ldots \ldots$

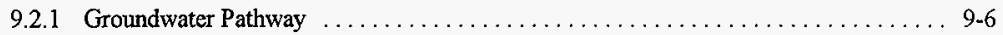

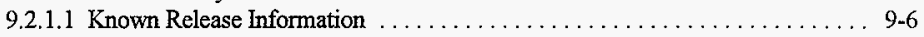

9.2.1.2 Potential for Human Exposure via the Groundwater Pathway . . . . . . . . . 9-7

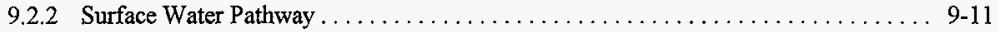

9.2.2.1 Known Release Information . . . . . . . . . . . . . . . . . . 9-11

9.2.2.2 Potential for Human Exposure via the Surface Water Pathway . . . . . . . . 9.11

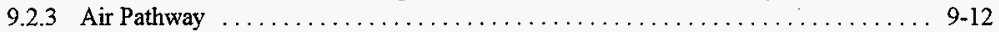

9.2.3.1 Known Release Information . . . . . . . . . . . . . . . . . . 9.13

9.2.3.2 Potential for Human Exposure via the Air Pathway . . . . . . . . . . . . 9-13

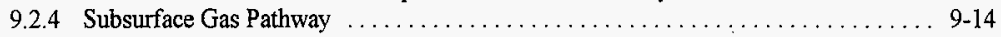

9.2.4.1 Known Release Information ......................... 9.15

9.2.4.2 Potential for Human Exposure via the Subsurface Gas Pathway . . . . . . . 9.15

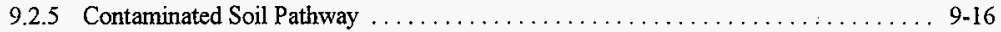

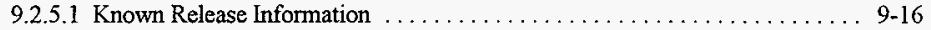

9.2.5.2 Potential for Human Exposure via the Contaminated Soil Pathway . . . . . . 9-16

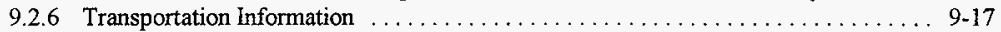

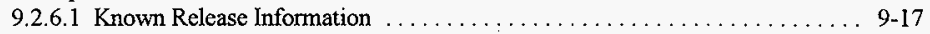

9.2.6.2 Potential for Human Exposure from Transportation-Related Releases . . . . 9. 9-17

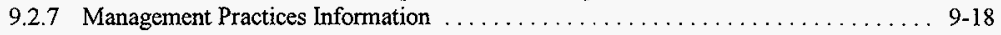

9.3 CONCLUSIONS ON EXPOSURE POTENTLAL $\ldots \ldots \ldots \ldots \ldots \ldots \ldots \ldots \ldots \ldots \ldots$

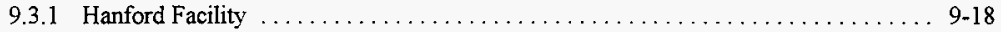

9.3.2. Surface Impoundment and/or Landfill TSD Units . . . . . . . . . . . . . 9-18 
3

4 9-1. Land Uses at the Hanford Site (adapted from DOE/EIS-0222).

F9-1

5 9-2. Population in the Vicinity of the Hanford Site.

\section{TABLE}

9

10

11 9-1. Information Requirements Checklist 


\subsection{EXPOSURE INFORMATION REPORT}

This chapter discusses exposure information for the Hanford Facility. Requirements for submittal of exposure information, administered by EPA, are contained in 40 CFR 270.10(j). Such information only is required for dangerous waste constituents in Part B permit application documentation pertaining to a surface impoundment or a landfill. Guidance for preparing an exposure information report is contained in EPA's Permit Applicants' Guidance Manual for Exposure Information Requirements under RCRA Section 3019 (Guidance Manual) (EPA 1986a). This Guidance Manual states that the information provided must address, at a minimum, the following three areas:

- Reasonably foreseeable potential releases from both normal operations and accidents, including releases associated with transportation to or from the facility

- The potential pathways of human exposure to dangerous wastes or constituents resulting from these releases

- The potential magnitude and nature of the human exposure resulting from such releases.

The Guidance Manual further states that the "EPA does not expect applicants to develop major, expensive new pieces of information..." to address these three areas.

This chapter is intended to provide an overview of available information regarding the potential for exposure to dangerous and/or mixed waste present at, or released from, 'operating' surface impoundment or landfill units on the Hanford Facility. These 'operating' TSD units currently include the LLBG and the LERF. Part B documentation for both of these units is contained in the Unit-Specific Portion of this permit application (i.e., DOE/RL-88-20 and DOE/RL-97-03, respectively).

The LLBG and LERF are located within, or near, the 200 Areas of the Hanford Facility (Appendix 2A). Thus, the focus of this chapter is to address reasonably foreseeable potential releases from both normal operations and accidents within the 200 Areas. This information includes releases associated with potential environmental transport pathways and routes of human exposure to dangerous and/or mixed waste. The information contained in this chapter need not be duplicated in the Unit-Specific Portion of this permit application, but will be cross-referenced, as appropriate. Information in this chapter also could be cross-referenced by preclosure work plan, closure work plan, closure plan, closure/postclosure plan, or postclosure permit application documentation, as appropriate. Most of the land-based TSD units 'undergoing closure' are located within the 200 Areas. In general, the exposure information discussed in this chapter would be the same information used to conduct an analysis of most TSD units in the 200 Areas.

\subsection{GENERAL INFORMATION}

This section provides general information for the Hanford Facility and for the LLBG and LERF. Also provided is a checklist (Table 9-1) that identifies sections of the Hanford Facility Dangerous Waste Permit Application where information relevant to Chapter 9.0 discussions can be found. 


\subsubsection{Risk Assessment Reports and Information}

This section summarizes health and risk assessment reports and other relevant information for the Hanford Facility and for the LLBG and LERF. The discussion is limited to dangerous waste constituents.

\subsubsection{Hanford Facility. A description of the Hanford Site and Hanford Facility is contained in}

Chapter 2.0. The Hanford Site maintains a sitewide environmental surveillance program to assess onsite and offsite environmental impacts and offsite human health exposures. This program monitors air, surface water, sediment, agricultural products, vegetation, soil, and wildlife. A description of this program is contained in the Hanford Site Environmental Monitoring Plan (Monitoring Plan) (DOE/RL-91-50).

Exposure information resulting from the Hanford Site environmental monitoring program is prepared and issued annually (Environmental Report) (e.g., PNNL-11139). The Environmental Report provides a summary of environmental data that are collected to characterize Hanford Site environmental management activities. This information is used to assess the exposure that results from the release of all effluents, from both ongoing and past operations, based on the contaminants that continue to reside in the soil and groundwater pathway.

A risk-based cleanup strategy has recently been prepared for the Hanford Site (PNL-10651). This study concluded that existing land use and access restrictions protect public health and safety. The current airborne, groundwater, and surface water exposures to the general public are much below background and are anticipated to be lower in the future. The study concluded that over the near-term (current through the remediation phase of Hanford Site cleanup), the primary exposure pathway of concern is through the air. Although the consequences associated with inhalation are large, the probability of occurrence is low. Over the long-term (post remediation phase), the study concluded that the exposure pathway of primary concern is groundwater. With regard to hazardous chemicals, the potential ingestion of carbon tetrachloride was found to be the single largest contributor of carcinogenic risk over the long-term. Similarly, nitrates were found to be the single largest contributor of noncarcinogenic risk.

The content of this chapter is based on information contained in the Monitoring Plan (DOE/RL-91-50), the Environmental Report (e.g., PNNL-01139), a risk-based cleanup strategy (PNL-106515), and DOE/EIA-0113, as well as a number of other general and specific documents that are cited throughout the text.

9.1.1.2 Surface Impoundment and/or Landfill TSD Units. This section summarizes risk assessment reports and information specific to the LLBG and LERF that addresses dangerous waste constituents (i.e., radiological studies are not included).

The LLBG, classified as a land-based unit, are located in the 200 Areas (refer to Appendix 2A). Three of the four operational burial grounds comprising this TSD unit are located in the 200 West Area; the remaining burial ground is located in the 200 East Area (refer to Chapter 4.0, Section 4.1.2.8 and DOE/RL-88-20).

Reports containing exposure information relevant to the LLBG include:

- Estimation of the Release and Transport of Lead through Soils and Groundwater at the Hanford Site 218-E-I2B Burial Ground (PNL 1992) 
- Estimation of the Release and Transport of Nickel through Soils and Groundwater at the Hanford Site 218-E-12B Burial Ground (PNL 1994)

- Extrapolation of Migration Modeling for Large Metal Components Containing Lead and Nickel Alloys at the 218-E-12B Burial Ground (USN 1995)

- Environmental Impact Statement on the Disposal of Decommissioned, Defueled Cruiser, Ohio Class, and Los Angeles Class Naval Reactor Plants (USN 1996).

- Solid Waste Burial Ground Interim Safety Basis (WHC-SD-W105-SAR-001).

These reports evaluate the release and transport potential of metals from the disposal of defueled naval reactor compartments.

The LERF, located in the 200 East Area (refer to Appendix 2A), is classified as a surface impoundment. The LERF provides interim treatment and storage of mixed effluent received from the 242-A Evaporator and other onsite sources (refer to Chapter 4.0, Section 4.1.2.4.). A baseline environmental survey has been performed on LERF that provided an assessment of potential impacts to the environment from operating LERF. In addition, the final safety analysis report examined the risk to human health associated with the release of ammonia (WHC-SD-WI05-SAR-001).

\subsubsection{Land Use}

The Hanford Site is federally owned and covers approximately 1,450 square kilometers (refer to Chapter 2.0, Figure 2-1). Figure 9-1 depicts the current land uses in and adjacent to the Hanford Site. As discussed later in this section, changes in Hanford Site land use and custodianship will need to be factored into future evaluations of exposure information.

Currently, the Hanford Site primarily is dedicated to U.S. Department of Energy-controlled operations, with limited exceptions. However, the future use of the Hanford Site currently is being evaluated (DOE/EIS-0222). In particular, the lands north and east of the Columbia River are under consideration for non-U.S. Department of Energy use and for ownership transfer. The portion of the Hanford Site that is located on the north and east sides of the Columbia River currently is used for wildlife refuge or wildlife recreation land. The stretch of the Columbia River within the Hanford Site boundary currently is being considered for addition to the National Wild and Scenic Rivers System (refer to Chapter 13.0, Section 13.1.1.10). The southwest portion of the Hanford Site is the Fitzner/Eberhardt Arid Lands Ecology Reserve. The portion of the Hanford Site south and west of the Columbia River is where reactor, fuel reprocessing, TSD units, and the Hazardous Material Management and Emergency Response Training Center are located. Additional information on this central area, which is most relevant to the discussions contained in this chapter, can be found in Chapter 2.0. This centrai area (i.e., the 200 Areas) contains the LLBG and LERF.

Also located within the boundaries of the Hanford Site are the Washington Public Power Supply System reactor and generating complex, the US Ecology, Inc. waste disposal facility, located southwest of the 200 East Area, and the National Science Foundation Laser Interferometer Gravitational Wave Observatory, located northwest of the 400 Area. Seimens Nuclear Power is located just north of Richland, Washington, 
adjacent to the Hanford Site boundary. The eastern boundary of the nearest military installation, the Yakima Firing Center, is 22 kilometers west-northwest of the Hanford Site.

Outside the Hanford Site are privately owned farms and the urban and suburban areas of Richland and West Richland, Washington.

On December 21, 1994, the Secretary of Energy issued a new land- and facility-use policy for the U.S. Department of Energy, which makes the following statement:

"It is Department of Energy policy to manage all of its land and facilities as valuable national resources. Our stewardship will be based on the principles of ecosystem management and sustainable development. We will integrate mission, economic, ecologic, social, and cultural factors in a comprehensive plan for each site that will guide land and facility use decisions. Each comprehensive plan will consider the site's larger regional context and be developed with stakeholder participation. This policy will result in land and facility uses which support the Department's critical missions, stimulate the economy, and protect the environment."

The DOE-RL has initiated a comprehensive land use planning process to evaluate specific and potential use of the different areas of the Hanford Site. To support this process, the DOE-RL is developing a comprehensive land use plan, which was released to the public during the summer of 1996 for review and comment as part of the draft Hanford Remedial Action Environmental Impact Statement and Comprehensive Land Use Plan (DOE/EIS-0222). This action satisfies Public Law 104-201 that requires the development of a draft future land use for the Hanford Site.

\subsubsection{Aerial Photographs}

A composite aerial photograph of the Hanford Facility is included in Appendix 2A. Large-scale maps and aerial photographs of the LLBG and LERF are included in the Unit-Specific Portion of this permit application.

\subsubsection{Summary of Waste Analysis Data}

The HF Part A provides waste characteristics information for TSD units (refer to Chapter 1.0). Process knowledge documentation and results of analyses have been, and will be, maintained with other TSD unit records (refer to Chapter 12.0, Section 12.1.16) and will be provided to Ecology and the EPA as required by applicable regulations. Waste analysis data for the LLBG and LERF are discussed in the Unit-Specific Portion of this permit application.

\subsubsection{Amount of Waste}

Currently, over 2,000 waste management units have been identified on the Hanford Site, the majority of which are identified as SWMUs in accordance with RCRA (DOE/RL-88-30) (refer to Appendix 2D, Section 1.2). Chapter 2.0, Section 2.5 and Appendix 2D, contain information on these waste management units. The Waste Information Data System (WIDS) is an electronic database that identifies known and reported SWMUs and other waste management units located on the Hanford Site (refer to Appendix 2D, 
1 Section 1.1). The WIDS includes the type and location of the unit, when the unit was operated, general

2 dimensions and description of the unit, and general descriptions of waste placed in the unit (including

3 estimated quantities of radionuclides and chemicals contained in some units). The WIDS database is

4 accessible to regulatory agency personnel. Information specific to LLBG and LERF is contained in the

5 WIDS and in the Unit-Specific Portion of this permit application.

6

7

\subsubsection{Records Produced by Environmental or Health Agencies}

A summary of Notice of Compliance Violations and the associated responses is maintained in the Hanford Facility Operating Record, General Information File (refer to Chapter 12.0, Section 12.1). This summary can be accessed by contacting the following:
Hanford Sitewide RCRA Permit
Facility Operating Record
Fluor Daniel Hanford, Inc.
P.O. Box 1000, Mail Stop H6-23
Richland, Washington 99352
(509) 376-9876.

The EPA inspected the Hanford Facility in 1986, 1987, and 1988. Copies of the inspection reports for 1987 and 1988 have been provided to Ecology.

A 1986 Consent Agreement and Compliance Order (Ecology DE-86-133) between the DOE-RL and Ecology provided that a RCRA groundwater monitoring system would be installed around portions of the LLBG that are used for mixed waste. One requirement of the order was that 35 wells would be installed around the LLBG to provide a detection-level groundwater monitoring network. These 35 wells have been installed. An additional 46 wells have been drilled to complete the groundwater monitoring network for a total of 81 wells as of 1994 . At the present time, 66 of the 81 wells are monitored routinely. Eleven wells used to monitor the 218 -W- 6 Burial Ground are not being used because no waste has been received; three wells at the 218-E-12B Burial Ground have gone dry; and a well in the 218-W-4C Burial Ground also has gone dry (refer to DOE/RL-88-20, Chapter 5.0).

At this time, no records have been produced by environmental or health agencies for the LERF.

\subsection{PATHWAY-SPECIFIC INFORMATION}

This section provides information on potential contaminant release pathways. Potential pathways discussed include the following:

- Groundwater pathway

- Surface water pathway

- Air pathway

- Subsurface gas pathway

- Contaminated soil pathway

- Transportation information. 
1 Information also is provided on transportation and management practices.

\subsubsection{Groundwater Pathway}

General information concerning the hydrogeology of the Hanford Site, and the groundwater monitoring program at the Hanford Facility, is provided in Chapter 5.0. Information concerning the RCRA groundwater monitoring program specific to the LLBG and LERF is contained in the Unit-Specific Portion of this permit application.

The aquifers beneath the Hanford Site include the unconfined aquifer in sediments of the Hanford and Ringold Formations and a series of confined aquifers in interbed layers of the Columbia River Basalt Group. Generally, the suprabasalt aquifer is hydraulically separated from the interbed aquifers by basalt flows. North of the 200 East Area, the uppermost basalt layer has been eroded away, allowing a connection between the suprabasalt aquifer and the interbed aquifers. Other areas of interconnection by erosion have been hypothesized, but have not been confirmed.

Over 3,400 wells are located on the Hanford Site for vadose zone characterization, groundwater monitoring, drinking water supply, and groundwater cleanup (pump and treat). Over 200 of the groundwater monitoring wells are located near or within the 200 Areas. Three wells, located in the 200 East Area, provide backup process water supply. These wells are not used to provide drinking water. The locations of these wells are discussed in Appendix 2A. Most water used at the 200 Areas is obtained from the Columbia River.

Several drinking water supply wells are located on the Hanford Facility. None of these wells are within 4.8 kilometers of the 200 Areas. The nearest water supply wells are the Yakima Barricade well, located about 5.2 kilometers west of the 200 West Area; the Rattlesnake Spring well, located about 6.4 kilometers southwest of the 200 West Area; and the Hanford Patrol Training Academy well, located about 24 kilometers southwest of the 200 Areas. The Rattlesnake Spring well is no longer in service because of lack of demand. Three wells, located at the Fast Flux Test Facility, supply drinking water to the 400 Area (refer to Chapter 2.0, Section 2.5.2.1) and are located approximately 19.3 kilometers downgradient from the 200 Areas.

No agricultural irrigation or commercial food preparation occurs on the Hanford Facility.

9.2.1.1 Known Release Information. The following sections provide a brief discussion of known release information for the Hanford Facility and for the LLBG and LERF.

9.2.1.1.1 Hanford Facility. Known release information for the Hanford Facility is maintained by the WIDS (refer to Section 9.1.5 and Appendix 2D, Section 1.1). In addition, groundwater monitoring results and contaminant plume maps are provided annually in such documents as the Environmental Report (e.g., PNNL-11139) and annual groundwater monitoring reports (e.g., DOE/RL-91-03).

9.2.1.1.2 Surface Impoundment and/or Landfill TSD Units. Following the installation of a RCRA groundwater monitoring network in 1987 , no known release of waste via the groundwater pathway has been reported for the LLBG.

The possibility of groundwater contamination is mitigated by the environmentally protective design and construction of the LERF, which is engineered to minimize the potential for release of contaminants, and 
1 by the site stratigraphy. Because the basins are constructed with double liners and leak detection systems,

2 failure of the containment system would be detected before a release could migrate through the unsaturated

3 zone to the aquifer. Following the installation of a RCRA groundwater monitoring network in 1991, no

4 known release of waste via the groundwater pathway has been reported for the LERF.

9.2.1.2 Potential for Human Exposure via the Groundwater Pathway. The following sections provide a brief discussion of the potential for human exposure via the groundwater pathway for the Hanford Facility and for the LLBG and LERF.

9.2.1.2.1 Hanford Facility. Groundwater maps in annual groundwater monitoring reports show the distribution of radiological (e.g., tritium) and hazardous chemical (e.g., carbon tetrachloride) contaminant plumes. Studies of these data, such as a recent risk-based cleanup strategy (PNL-10651), have shown that the potential exposure to these levels of groundwater contamination are below acceptable thresholds. The existing levels of groundwater contamination are anticipated to be lower in the future. However, this risk-based cleanup strategy did conclude that the route of primary concern from long-term exposure is the groundwater pathway. With regard to hazardous chemicals, carbon tetrachloride was found to be the single largest contributor of carcinogenic risk in the groundwater from the chemical constituents that were analyzed, and nitrates were found to be the single largest contributor of noncarcinogenic risk. Hanford Site groundwater remediation efforts will focus on mitigating the impact of these contaminants on the Columbia River (DOE/RL-94-95).

Given the low usage of the several drinking water wells on the Hanford Site (refer to Section 9.2.1), and the size of population these serve, the potential for human exposure is low. All drinking water wells are considered public water supply wells and are handled, monitored, sampled, and tracked for performance in accordance with WAC 246-290. Samples are submitted to Washington State certified laboratories for analysis. In September 1995, a draft Hanford Site wellhead protection plan was prepared and submitted to Ecology for review. This plan continues to be reviewed annually by the Washington State Department of Health.

Information available for the Hanford Facility is used to provide a general evaluation of the potential for exposure via:

- Release of waste from the 200 Areas

- Migration through the vadose zone

- Groundwater transport to the Columbia River without detection

- Human exposure via the Columbia River.

Release of Waste from the 200 Areas. Most of the Hanford Facility TSD units are located within the 200 Areas. For human exposure via the groundwater pathway to occur, waste must first move beyond these TSD units. Systems in place, or planned, for 'operating' TSD units are designed to prevent movement of waste from the TSD unit. The disposal of unpermitted liquid effluents in land-based TSD units has ceased. Therefore, it is unlikely that 'operating' TSD units, or TSD units 'undergoing closure', would contribute to a release of waste to, or from, the 200 Areas that is not already attributable to earlier waste disposal practices.

Migration Through the Vadose Zone. The low precipitation amounts and high evapotranspiration rates on the Hanford Site reduce the possibility that chemical constituents from the waste could reach the water table (refer to Chapter 5.0, Sections 5.3.1 and 5.3.2). For chemical constituents from the waste to 
1 reach the groundwater, these constituents must be transported through the vadose zone sediments. This column of sediments is approximately 56.4- to 86.9-meters thick beneath the 200 Areas.

Groundwater Transport to the Columbia River Without Detection. Assuming that waste had breached a containment system and migrated through the soil to the water table, the contamination would have to move beyond the source areas without first being detected by operations personnel or the existing RCRA groundwater monitoring well systems. An extensive groundwater monitoring network is in place at the Hanford Facility and should be able to detect any changes of significance.

Human Exposure via the Columbia River. Several factors reduce the possibility for human exposure via the Columbia River and include (1) containment systems, (2) warning systems, (3) low infiltration rates from the various TSD units, and (4) generally thick sequences of vadose zone sediments. If contaminants from the waste do reach the groundwater, the groundwater monitoring systems should detect the release, and a compliance and/or corrective action program would be initiated. The distance between the 200 Areas and public drinking water supply wells provides additional protection as described in the draft Hanford Site wellhead protection pian. Finally, if contamination should reach the Columbia River, dilution would reduce concentrations by at least several orders of magnitude compared to groundwater concentrations.

In summary, it is unlikely that managing dangerous or mixed waste at TSD units within the 200 Areas would result in unacceptable exposure to humans via the groundwater pathway. For human exposure to occur, contaminants from the waste must first breach containment systems without detection, migrate to the water table, and migrate to the Columbia River. Unit-specific information that supports this conclusion is discussed in the next section.

9.2.1.2.2 Surface Impoundment and/or Landfill TSD Units. The LERF, because of its design, is an unlikely contaminant source. However, mixed waste has been disposed of in unlined trenches in the LLBG. Therefore, the discussion in the remainder of this section will focus on the potential for human exposure via the groundwater pathway from the LLBG.

As noted in Section 9.2.1.2.1, given the low usage of drinking water wells on the Hanford Site, and the applied wellhead protection standards required by WAC $246-290$, the potential for human exposure from LLBG contaminants is low. The potential for human exposure via the groundwater pathway to the Columbia River is more significant, and will be the focus of the following analysis for the LLBG. Discussion of the groundwater pathway will be subdivided into the following:

- Release of waste from containment

- Migration through the vadose zone

- Groundwater transport to the Columbia River without detection

- Human exposure via the Columbia River.

Release of Waste from Containment. The containment system for the two newly constructed lined trenches in the LLBG (refer to Chapter 4.0, Section 4.5.3) is described in the Unit-Specific Portion of this permit application. The design for these trenches consists of a leachate liner system that will prevent migration of mixed waste out of the landfill. Leachate from this system will be collected, treated, and disposed.

Lack of records and well-defined disposal procedures make it difficult to predict the potential for release into the soil of chemicals from waste disposed of in the past. It is certain that dangerous waste 
1 disposed of in the past was not contained as well as is planned for future waste disposal. However, as discussed in Section 9.2.1.1.2, no known release of contaminants has been reported for the LLBG since 1987, the year groundwater monitoring was initiated. Assessment actions have shown that groundwater contamination is attributable to nearby, inactive liquid waste disposal sites.

Migration Through the Vadose Zone. The low precipitation and high evapotranspiration on the Hanford Facility reduce the possibility that chemicals from the waste could reach the water table. Between 56.4 to 86.9 meters of unsaturated sediments separate the water table from the ground surface in the LLBG. For chemicals from the waste to reach groundwater, the chemicals must be transported through this column of sediments. Several scenarios for vadose zone migration are considered; all of the scenarios require that waste has escaped from the containment system.

The furst scenario is that enough liquid waste is released to exceed the specific retention through a depth of sediments greater than 54.9 meters. Specific retention is the saturation value below which no flow is possible. Although specific retention depends to some extent on characteristics of the liquid, specific retention depends primarily on the pore size of the sediments. Given the low recharge rate, the specific retention for water in soil near the LLBG is assumed to be the lowest moisture content measured in nearby soil samples. Data indicate that the lowest moisture content in borings performed for the detection-level monitoring network was about 1.0 to 2.0 percent.

Using some conservative assumptions, it is possible to examine the feasibility of a liquid release reaching the water table. For example, assume a release of 100 liters of liquid waste and a specific retention of 0.005 . Given these assumptions, the liquid only could penetrate a volume of 21.5 cubic meters before the flow stopped. The layered sediments in the Hanford formation (refer to Chapter 5.0, Section 5.3) likely would cause significant horizontal migration. Assuming the liquid spreads into a cylinder with a diameter of 3 meters, the liquid would only reach a depth of 2.7 meters. This analysis suggests that it is unlikely that the waste would reach the water table via this mechanism.

The second scenario is that infiltrating precipitation comes into contact with the waste and transports chemical constituents to the water tabie. The closure and postclosure plans call for a vegetated cover over the LLBG that is designed to minimize infiltration, erosion, and differential settling. In regions with vegetated, fine-grained soils, recharge has been observed to be less than 0.1 centimeter per year (refer to Chapter 5.0, Section 5.3). It is likely that a soil cover designed and maintained to minimize infiltration would perform equally well. It is conceivable that cracks or settling could disrupt the integrity of the cover and allow some infiltration to reach the waste. Although frequent inspections would minimize the impact of such an event, it is difficult to predict how much infiltration would reach the waste in the event of a failed cover. At a recharge rate of 0.1 centimeter per year, the estimated contaminant travel time to the groundwater beneath the 200 Areas is greater than several thousand years (Gee et al. 1992) (refer to Chapter 5.0, Section 5.3.7.1 for additional information on contaminant travel times).

A third scenario is that artificial recharge migrates horizontally to the waste buried in the LLBG, becomes contaminated, and flows vertically to the water table. Although several waste water disposal units are located near the LLBG (Appendix 2A), the practice of discharging process waste water to the soil column has been discontinued on the Hanford Site.

The final scenario is that volatile organic constituents reach the water table by vapor diffusion through the soil. Very little research has been performed on this phenomena. Numerical solutions of a hypothetical site (Silka 1988) suggest that vapor diffusion could be a significant vadose zone transport mechanism. 
1 However, the distance to the water table is greater than 56.4 meters, and the distance to the surface is less

2 than 15.2 meters. Vapor diffusion would occur radially and would be expected to reach the surface before the

3 vapor reached the water table. When the vapor plume reaches the surface, concentration gradients would

4 favor upward movement over downward movement. Because of the expected preferential upward movement

5 and the small quantity of waste to disperse, the quantity of dangerous waste that could reach the water table would unlikely be sufficient to raise the contaminant concentrations above the regulatory standards.

Groundwater Transport to the Columbia River Without Detection. Assuming that chemicals from the waste had breached the containment system and migrated to the water table, the contamination would have to move beyond the LLBG before being detected in a groundwater monitoring well. The groundwater monitoring system has been designed to detect any plumes before the plumes migrate more than 152.4 meters beyond the LLBG. Given the variability of velocity and direction of groundwater beneath the 200 East Area, it would be important to quickly implement a remediation scheme once a release is detected. The shortest distance between the LLBG and the Columbia River is 8 kilometers. The total distance is controlled by the DOE-RL and is not inhabited; thus, a buffer zone surrounds the LLBG. The contaminant travel time to the Columbia River from the LLBG in the 200 West Area is estimated at more than 80 years. From the LLBG in the 200 East Area, contaminant travel time is estimated to be more than 10 to 20 years.

Human Exposure via the Columbia River. If chemicals from the LLBG were to reach the Columbia River, these chemicals would be diluted by several orders of magnitude because of the large flow rate. Assuming that the Columbia River is at its lowest recorded flow of 123 cubic meters per second (DOE/EIS-0113), the cross-section of the groundwater plume is 298.7 meters by 49.7 meters, and the Darcy flux into the Columbia River is 2 meters per day, the dilution factor in the Columbia River would be 0.0015 . The Darcy flux of 1.0 meter per day is actually greater than would be expected near the Columbia River. Based on published data (RHO-BWI-ST-5, Plate III-4), the hydraulic gradient is typically 0.001 or greater. Under a gradient of 0.001 , a Darcy flux of 1.0 meter per day would require a hydraulic conductivity of 1,005.8 meters per day. Hydraulic conductivities in the vicinity of the river (RHO-BWI-ST-5, Plate III-5) range from about 6.1 to 152.5 meters per day. A lower conductivity would result in a lower Darcy flux; thus the flux value of 1.0 meters per day conservatively overestimates the discharge to the river and underestimates the amount of dilution occurring. This dilution factor means that the concentration in the Columbia River. would be almost three orders of magnitude less than the concentration in groundwater. Because the average flow in the Columbia River is 3,600 cubic meters per second, this estimate is conservative. The dilution factor of the Columbia River would result in much lower exposures to anyone using the water downstream than the assumed value of 0.0015 .

In summary, it is unlikely that future disposal of mixed waste at the LLBG will result in unacceptable exposure for humans via the groundwater pathway. For human exposure to occur, chemicals from the waste must first breach the containment system without detection and migrate to the water table. Several factors reduce the possibility of this occurring, including (1) the containment system, (2) the vegetated cover design, (3) the low infiltration rate at the LLBG, and (4) the thick sequence of vadose zone sediments. If chemicals from the waste do reach the groundwater, the detection-level groundwater monitoring system should detect the release and a remediation program would be initiated. Finally, if contamination should reach the Columbia River, dilution would reduce concentrations by at least several orders of magnitude compared to groundwater concentrations. A detection-level groundwater monitoring system has been installed and sampling is ongoing. The results of this sampling program should determine if waste from the LLBG has reached the water table and is migrating beyond the LLBG. After 8 years of monitoring, no contamination attributed to the LLBG has been detected. 


\subsubsection{Surface Water Pathway}

This section provides a brief discussion of surface water pathways for the Hanford Facility and for the LLBG and LERF.

The only natural surface water bodies on the Hanford Site are the Columbia and Yakima Rivers, Cold Creek drainage, and West Lake. The locations of these water bodies are shown in Chapter 2.0, Figures 2-9, and 2-10, and discussed in Appendix 2A. The Cold Creek drainage is an ephemeral and discontinuous stream (refer to Chapter 2.0, Section 2.2.1.4). The only permanent surface water body within 4.8 kilometers of the 200 Areas is West Lake. This lake is not used by humans for any commercial, agricultural, or recreational activity. The lake is, however, frequented by birds and other wildlife. A prominent surface water body in the past, the 216-B-3 Main Pond (refer to Appendix 2A), has been stabilized and no longer is in service. In addition, the adjacent 216-B-3 Expansion Ponds (refer to Appendix 2A) have been clean closed.

The 100-year floodplain for the Yakima and Columbia Rivers does not extend to the 200 Areas (refer to Chapter 2.0, Section 2.2.1.4). During periods of heavy precipitation, flooding could occur in the Cold Creek Valley, located along the west side of the Hanford Site. As shown in Chapter 2.0, the probable maximum flood in the Cold Creek watershed would reach only the western edge of the 200 West Area. The 100-year flood would be less than the probable maximum flood.

9.2.2.1 Known Release Information. The following sections provide a brief discussion of known release information for the Hanford Facility and for the LLBG and LERF.

9.2.2.1.1 Hanford Facility. Known release information for the Hanford Facility is maintained in the WIDS. In addition, monitoring data for areas within the vicinity of the surface water bodies discussed in Section 9.2.2 are contained in the Environmental Report (PNNL-1 1139). These data indicate that releases from these surface water bodies are below concentrations of concern. These data also indicate that there was no indication during 1994 of any deterioration in the water quality along the Hanford Reach of the Columbia River resulting from Hanford Site operations. Potential sources of pollutants not associated with Hanford Site operations include irrigation return and direct runoff from agricultural activities located along the north and east sides of the Columbia River.

9.2.2.1.2. Surface Impoundment and/or Landfill TSD Units. No known release of mixed waste via the surface water pathway has been reported at the LLBG since 1984 (the year back to which data were reviewed for this chapter).

No know release of mixed waste via the surface water pathway has been reported from the LERF since this TSD unit became operational in 1994.

9.2.2.2 Potential for Human Exposure via the Surface Water Pathway. The following sections provide a brief discussion of the potential for human exposure via the surface water pathway for the Hanford Facility and for the LLBG and LERF.

9.2.2.2.1 Hanford Facility. Because of its location near the center of the Hanford Site, there is very limited potential for humans to be exposed to contaminants originating from the 200 Areas via the surface water pathway. For there to be even a possibility of this occurring, a large scale release of dangerous waste would need to occur simultaneously with a major precipitation or flooding event. 
Two principal scenarios have been considered in assessing the potential for human exposure via surface water pathways. The first is surface run-off of precipitation that is contaminated with waste. The second is flooding of a surface water body into a TSD unit(s).

The first scenario requires a large enough precipitation event to result in significant overland flow. Large precipitation events are infrequent in the Pasco Basin (refer to Chapter 5.0, Sections 5.3.1 and 5.3.2). Days with greater than 1.3 centimeters of precipitation occur less than 1 percent of the year, and rainfall intensity of 2.5 centimeters in 1 hour are estimated to have a recurrence interval of 500 years (DOE/EIS-0113). Furthermore, given the flat topography and gravelly/sandy soils at the Hanford Site, significant overland flow rarely occurs (refer to Chapter 2.0, Section 2.2.1.4).

The second scenario involves flooding of a surface body of water into a TSD unit(s). The TSD units located in the 200 Areas are above the maximum flood levels of either the Columbia or Yakima Rivers and the Cold Creek drainage (refer to Chapter 2.0, Section 2.2.1.4). Thus, this scenario is considered unlikely.

Given the elevated, but flat, topography of the 200 Areas, the low precipitation, and the lack of nearby surface water bodies, the potential for human exposure to surface water that has been contaminated with dangerous and/or mixed waste is low.

9.2.2.2.2 Surface Impoundment and/or Landfill TSD Units. For the LLBG and LERF, the two major scenarios to be considered when assessing the potential for human exposure via surface water pathways, involve surface run-off of precipitation that is contaminated with waste, and flooding of a surface water body into either of these TSD units. Because of the factors mentioned for the Hanford Facility (refer to Section 9.2.2.2.1), it is unlikely that such conditions would exist within the 200 Areas where the LLBG and LERF are located.

\subsubsection{Air Pathway}

The 200 Areas of the Hanford Facility are located approximately 32 kilometers from Richland, Washington, the nearest population center. Protection of the general public is afforded by limited access to the 200 Areas.

Climatological data have been collected since 1945 at the Hanford Meteorological Station, located between the 200 Areas (refer to Chapter 2.0, Section 2.2.1.3; Chapter 5.0, Sections 5.3.1 and 5.3.2). Prevailing wind directions in the 200 Areas are from the northwest in all months of the year; secondary maxima occur for southwesterly winds. High winds that cause dust storms are usually from the southwest. High winds also are associated with afternoon drainage winds from the northwest, frequently reaching velocities of 50 kilometers per hour. Wind roses for several locations within the Hanford Site are shown in Chapter 2.0, Figure 2-7.

High winds from the northwest are associated with thunderstorms. The average occurrence of thunderstorms is 10 per year, typically occurring in the summer months, although thunderstorms have occurred in all months.

DOE/EIS-0113 lists no violent tornadoes for the region surrounding the Hanford Site. Predictions cited in this environmental impact statement (PNL-6415) estimate the probability of a tornado striking a point on the Hanford Site as $9.6 \times 10^{-6}$ per year. . 
9.2.3.1 Known Release Information. The following sections provide a brief discussion of known release information for the Hanford Facility and for the LLBG and the LERF.

9.2.3.1.1 Hanford Facility. Data from the airborne monitoring program (DOE/RL-91-50; PNNL-1 1 139) for the Hanford Facility indicate that releases via the air pathway are below concentrations of concern. A map showing population centers in the vicinity of the Hanford Facility is provided as Figure 9-2. No member of the public resides within 11 kilometers of the 200 Areas.

9.2.3.1.2 Surface Impoundment and/or Landfill TSD Unit. No known release of waste via the air pathway has been reported for the LLBG since 1984 (the year back to which data were reviewed for this chapter).

No known accidental release of waste via the air pathway has been reported for the LERF since this TSD unit began operation in 1994.

9.2.3.2 Potential for Human Exposure via the Air Pathway. The following sections provide a brief discussion of the potential for human exposure via the air pathway for the Hanford Facility and for the LLBG and LERF.

9.2.3.2.1 Hanford Facility. An important factor that reduces the risk of human exposure via the air pathway is the large uninhabited buffer zone that separates the 200 Areas from surrounding areas. The nearest major population center is Richland, Washington, located approximately 32 kilometers southeast of the 200 Areas (Figure 9-2). Because of the remote location and the management practices implemented within the 200 Areas, the potential for human exposure via the air pathway is considered low.

Atmospheric releases of radioactive and nonradioactive materials from the Hanford Site have been monitored for decades both onsite and offsite. As part of the environmental surveillance, air sampling for volatile organic compounds and polychlorinated biphenyl (PCB) compounds is performed routinely both onsite and offsite. All measured air concentrations of these compounds remain well below applicable maximum concentration standards for air contaminants (PNNL-11139).

The Hanford Site continues to operate under a Prevention of Significant Deterioration permit issued by the EPA (refer to Chapter 13.0, Sections 13.1.1.3 and 13.1.2.1). The permit sets limits for the release of nitrogen oxides from operating facilities. During 1995, the Hanford Site complied with the conditions of this permit (PNNL-11139).

As stated in the Environmental Report (PNNL-11139), with the exception of PCBs, all sampling of onsite nonradiological constituents remained below the detection level of 50 nanograms per sample component, which yields air concentrations of less than 0.03 to 0.1 nanograms per cubic meter. The measured $\mathrm{PCB}$ concentrations range from 0.25 to 3.9 nanograms per cubic meter and were well below the Occupational Safety and Health limit of 1,000 nanograms per cubic meter.

As a point of information, sampling of radiological constituents also continues. The site perimeter measurement of all radiological constituents remained at extremely low concentrations. Generally speaking, these concentrations were found to be less than 0.001 percent of the derived concentration guidelines (a calculated concentration that would result in an annual dose of $100 \mathrm{mrem}$ ) (Appendix 2B) for all radionuclides except uranium. For uranium isotopes, the measured concentrations were calculated to be 0.06 percent of derived concentration guidelines. 
9.2.3.2.2 Surface Impoundment and/or Landfill TSD Units. For human exposure via the air pathway to occur at the $L L B G$, the waste would have to be released to the environment during transport or loading/unloading, or after burial. Varied methods are used to prevent wind dispersal of dangerous waste, depending on the waste form. Methods to prevent wind dispersal include containerization, stabilization, grouting, spray fixitants, and backfill. Sometimes the natural form of the waste precludes the need for wind dispersal protection (i.e., scrap piping and other solid debris). In other instances, practices include implementation of a wind speed restriction and immediately backfilling the waste to prevent wind dispersal.

An important factor that reduces the risk of human exposure via the air pathway is the large uninhabited buffer zone that surrounds the LLBG. The shortest distance between the LLBG and the Hanford Site boundaries is about 11 kilometers. As shown in Figure 9-2, the nearest major population ceriter is Richland, located approximately 32 kilometers southeast of the 200 Areas. For this reason, the potential for human exposure via the air pathway is low.

The LERF evaluation does not include consideration of a rupture of the pipeline from the treatment units to the storage basins because the pipeline is double contained. The potential for exposure to humans and the surrounding environment, therefore, would be limited to evaporation, emissions from basin overfill, or from spills of effluent stored in the basins. The LERF design addresses these potentials for release.

The LERF basins are designed with floating geomembrane covers (DOE/RL-97-03, Chapter 4.0) stretched over each basin above the primary and secondary liners. The covers are equipped with tensioning systems to prevent winds from blowing the covers off the basins. The covers are made of materials resistant to atmospheric degradation and are equipped with activated charcoal filtered breathers for ventilation of the basins. These vents allow the escape of gases while filtering out the organic components from the gases. The covers are anchored in concrete footings at the perimeter of the impoundments and are held in place with tension cables to prevent wind damage.

Various means of accidental release of ammonia from the 242-A Evaporator and the LERF were evaluated (WHC-SD-W105-SAR-001). Three credible confinement breaches (a spill, a spray leak from the LERF, and loss of the LERF basin cover) were examined. The maximum exposure to an individual from the accidental release of ammonia through a spill was calculated to be $1.3 \mathrm{E}-03$ milligrams per cubic meter to an offsite individual and 4.3 milligrams per cubic meter to an onsite individual located 100 meters from the point of release. The maximum exposure to an individual from the accidental release of ammonia via spray was calculated to be $<0.136$ milligrams per cubic meter to an onsite individual. The maximum exposure to an offsite individual resulting from a torn basin cover was calculated to be 0.12 milligram per cubic meter. All of the calculated exposures are unmitigated. Onsite and offsite radiological and toxicological consequences are well below the limiting risk/acceptance values. Accordingly, no significant onsite or offsite toxicological consequences were found to exist from the release of ammonia (WHC-SD-W105-SAR-001).

\subsubsection{Subsurface Gas Pathway}

Gas generation from the decomposition of municipal waste is a major concern in subsurface gas pathway assessment. No municipal waste disposal is carried out within the 200 Areas; therefore, no gas generation from biologic degradation is anticipated. Minor amounts of gas potentially could result from the vaporization of volatile constituents or from chemical reaction. However, the design of 200 Areas TSD units allows for the venting of such gases. 
1 9.2.4.1 Known Release Information. The following sections provide a brief discussion of known release information for the Hanford Facility and for the LLBG and the LERF.

9.2.4.1.1 Hanford Facility. No specific data are available to determine if releases have occurred from the Hanford Facility via the subsurface gas pathways. However, because of knowledge of disposal practices on the Hanford Site, the generation of such gas is considered to be remote.

9.2.4.1.2 Surface Impoundment and/or Landfill TSD Unit. No known release of waste via the subsurface gas pathway has been reported for the LLBG since 1984 (the year back to which data were reviewed for this chapter).

No known release of waste via the subsurface gas pathway has been reported for the LERF since this TSD unit began operation in 1994.

9.2.4.2 Potential for Human Exposure via the Subsurface Gas Pathway. The following sections provide a brief discussion of the potential for human exposure via the subsurface gas pathway for the Hanford Facility and for the LLBG and LERF.

9.2.4.2.1 Hanford Facility. As previously discussed, a major concern in subsurface gas pathway assessment is gaseous decomposition products resulting from municipal waste. As no municipal waste is disposed of within the 200 Areas, it is unlikely that significant amounts of gas would be produced. Thus, the design of Hanford Facility TSD units, and the absence of municipal waste, minimize the potential for human exposure from the subsurface gas pathway.

9.2.4.2.2 Surface Impoundment and/or Landfill TSD Units. As no municipal waste is disposed of at the $L L B G$, it is unlikely that significant amounts of gas would be produced. Small amounts of gas potentially could result from evaporation of volatile constituents, or chemical reaction, or decomposition of animal carcasses. The few carcasses that are disposed in the LLBG are widely distributed and are treated with slaked lime for disposal. Preliminary testing for radiolytic gas generation indicated that gas generation was not of concern.

Another transport mechanism could be gas migration along buried pipelines. Of the identified burial grounds, three burial grounds are within 30.5 meters of a buried pipeline. Given the porous nature of the native material in the area, and the common practice of backfilling pipe trenches with native material, the potential for gas migration along pipelines is judged to be minimal. The contrast between the surrounding soil porosity and the backfill porosity is thought not to be sufficient to concentrate the gas flow. Furthermore, the increased porosity of the backfill would tend to disperse gas to the surface rather than concentrate the gas along the pipeline.

The LERF containment system is designed to limit significant releases of gas to the environment if gas production did occur. Although a number of buildings and pipelines are located in the 200 East Area, west and north of the LERF, this situation should not be a problem considering the low potential for the accidental release of ammonia. 


\subsubsection{Contaminated Soil Pathway}

One transport mechanism of contaminants is the slow diffusion and advection through the soil column by soil water in the vadose zone. Beneath the 200 Areas this is expected to be a slow process, unless the transport process is aided by introducing a liquid that locally saturates the soil column. While a contaminant resides in the soil column, the vectors that influence exposure are: dermal, ingestion of soil, inhalation of soil, and consumption of crops. For the Hanford Site, this pathway and associated vectors are considered to be of secondary importance. No food chain crops are grown on the Hanford Site and game, that could concentrate contaminants through grazing, is controlled.

9.2.5.1 Known Release Information. The following sections provide a brief discussion of known release information for the Hanford Facility and for the LLBG and the LERF.

9.2.5.1.1 Hanford Facility. Data from the airborne monitoring program for the Hanford Site (DOE/RL-91-50; PNNL-11139) indicate that releases via the contaminated soil pathway are below concentrations of concern.

9.2.5.1.2 Surface Impoundment and/or Landfill TSD Unit. No known release of waste via the contaminated soil pathway has been reported for the LLBG via the soil pathway since 1984 (the year back to which data were reviewed for this chapter).

No known release of waste via the contaminated soil pathway has been reported for the LERF since this TSD unit began operation in 1994.

9.2.5.2 Potential for Human Exposure via the Contaminated Soil Pathway. The following sections provide a brief discussion of the potential for human exposure via the contaminated soil pathway for the Hanford Facility and for the LLBG and LERF.

9.2.5.2.1 Hanford Facility. Factors that reduce the risk of human exposure via the soil pathway are the limited public access to the Hanford Facility and the lack of nearby residential or agricultural areas. No food-chain crops currently are raised on the Hanford Site. Administrative control of the Hanford Site by the DOE-RL will preclude contact through food chain crops as long as that control is maintained. Therefore, the risk for human exposure via the soil pathway is low.

9.2.5.2.2 Surface Impoundment and/or Landfill TSD Units. The potential for human exposure from chemical and gas releases to the soil at the LLBG is minimized by operational controls. All mixed waste destined for LLBG must meet LDR requirements. The mixed waste can be either in containers or in bulk. If in bulk, the use of dust suppression or fixatives will be employed to minimize dust generation. In addition, at the end of an operating day, bulk waste will be covered with a fixative agent or other approved covers. If a release were to occur from the LLBG, the Hanford Facility has adequate resources for emergency response and dangerous waste cleanup (refer to Chapter 7.0 and Appendix 7A). The LLBG protocols for emergency response, evacuation, and cleanup activities are outlined in the Unit-Specific Portion of this permit application (DOE/RL-88-20, Chapter 7.0 and Appendix 7A).

The LERF is designed, in accordance with WAC 173-303-650, to minimize the potential for releases of dangerous chemicals to the soil. Double liners, with a leachate detection, collection, and removal system, are used in each of the surface impoundments. Therefore, the potential for contaminant migration via the soil pathway is low. 
2

3

\subsubsection{Transportation Information}

Packaging, inspection, and transportation of dangerous and mixed waste on the Hanford Facility are conducted in accordance with applicable regulations and follow strict procedures. Special attention is given to notifying personnel, when appropriate, of waste transfers requiring special precautions. For example, onsite transportation routes could be isolated through the use of barriers. In addition, the transporting of all extremely dangerous or hazardous material does not occur when the wind speed is greater than 16 kilometers per hour.

Transportation routes and traffic information for the Hanford Facility are discussed in Chapter 2.0, Section 2.4. Further information on manifesting and waste tracking for waste transported offsite and onsite is discussed in Chapter 3.0, Sections 3.3 and 3.4. Procedures for cleanup of spills or leaks occurring during transport or loading/unloading activities on the Hanford Facility are discussed in Chapter 7.0, Appendix 7A. Specific transportation information for the LLBG and LERF is contained in the Unit-Specific Portion of this permit application.

9.2.6.1 Known Release Information. The following sections provide a brief discussion of known release information for the Hanford Facility and for the LLBG and the LERF.

9.2.6.1.1 Hanford Facility. No significant releases of dangerous or mixed waste due to transportation incidents have been reported for the Hanford Facility.

9.2.6.1.2 Surface Impoundment and/or Landfill TSD Unit. No known significant releases of waste due to transportation incidents have been reported for the LLBG since 1984 (the year back to which data were reviewed for this chapter).

No known releases of waste due to transportation incidents have been reported for the LERF since this TSD unit began operation in 1994.

9.2.6.2 Potential for Human Exposure from Transportation-Related Releases. The following sections provide a brief discussion of the potential for human exposure via transportation incidents for the Hanford Facility and for the LLBG and LERF.

9.2.6.2.1 Hanford Facility. Because transportation is conducted on the Hanford Facility under strict controls, the likelihood of human exposure due to a transportation incident is considered to be low. All offsite transportation of dangerous waste is performed by certified shippers in accordance with U.S. Department of Transportation requirements.

9.2.6.2.2 Surface Impoundment and/or Landfill TSD Units. Most of the waste for the LLBG originates onsite. Trucks or railroad cars are used to transport waste to the LLBG. Particularly dangerous shipments could be limited to speeds of 24.1 kilometers per hour, and roads could be barricaded if the risk of radiation and/or chemical exposure warrants it (refer to Chapter 2.0, Section 2.4; Chapter 3.0, Sections 3.3 and 3.4). Waste shipments received from offsite are inspected at the 1100 Area before being transported to the LLBG. 
Given that most waste is generated and transported onsite, and given the low population density surrounding the Hanford Site and the precautions taken with dangerous and/or mixed waste, the risk of human exposure during transport is considered to be low.

Offsite transportation of waste from the LERF is not conducted; LERF effluents do not leave the 200 Areas. Onsite transportation of the effluent is facilitated by an underground piping system from the 242-A Evaporator directly to the LERF (refer to Chapter 4.0, Sections 4.1.2.3 and 4.1.2.4) and by strict transportation methods.

\subsubsection{Management Practices Information}

Management practices such as inspections, monitors, alarms, double-containment systems, and operating procedures are designed to limit the effects on human health and the environment from Hanford Facility operations. Measures to minimize exposure (refer to Chapter 6.0, General Information and Unit-Specific Portions) and contingency plans (refer to Chapter 7.0, General Information and Unit-Specific Portions) are designed to ensure that exposure to both workers and offsite individuals is minimized.

\subsection{CONCLUSIONS ON EXPOSURE POTENTIAL}

This section contains a brief discussion of the conclusions on exposure potential for the Hanford Facility and for the LLBG and LERF.

\subsubsection{Hanford Facility}

A recently developed risk-based cleanup strategy prepared for the Hanford Site (PNL-10651) concluded that existing land use and access restrictions protect public health and safety. The current airborne, groundwater, and surface water exposures to the general public that result from the normal operation of surface impoundments and landfills are a small fraction of normal background and well within acceptable limits. Furthermore, all exposures are anticipated to be lower in the future. The study determined that the route of primary concern from long-term (post remediation phase) exposure is the groundwater pathway. With regard to hazardous chemicals, carbon tetrachloride was found to be the single largest contributor of carcinogenic risk in the groundwater from the chemical constituents that were analyzed, and nitrates were found to be the single largest contributor of noncarcinogenic risk. Hanford Site groundwater remediation efforts will focus on mitigating the impact of these contaminants on the Columbia River (DOE/RL-94-95).

\subsubsection{Surface Impoundment and/or Landfill TSD Units}

The potential for exposure to dangerous and/or mixed waste is minimized by (1) the relative isolation of the LLBG and the LERF from population centers; (2) the large distance through the soil column that a contaminant would have to travel to the groundwater should a release occur and; (3) the highly unlikely event of overland flow. Therefore, potential exposure via the air pathways, soil, and surface water, is low. Present and proposed management practices appear to be effective and are not a cause for concern. 
Releases from the groundwater pathway appears to be the most likely pathway for human exposure should a release from a TSD unit occur. For human exposure to waste to occur from the groundwater, waste has to first breach containment systems and be of sufficient volume to overcome soil depth and retention factors to reach the groundwater. On reaching the groundwater, the contaminants must then migrate to the Columbia River. In addition, the contaminants would have to overcome the dilution factor of the Columbia River. Therefore, the potential for human exposure from LLBG and LERF operations, via the groundwater pathway, is low.

Strict transportation methods limit the risk of human exposure associated with the transportation of waste to the LLBG, offsite and onsite. Because no waste is transported offsite from the LERF, the risk is nil. 
DOE/RL-91-28, Rev. 4

$05 / 98$

This page intentionally left blank. 
DOE/RL-91-28, Rev. 4 05/98

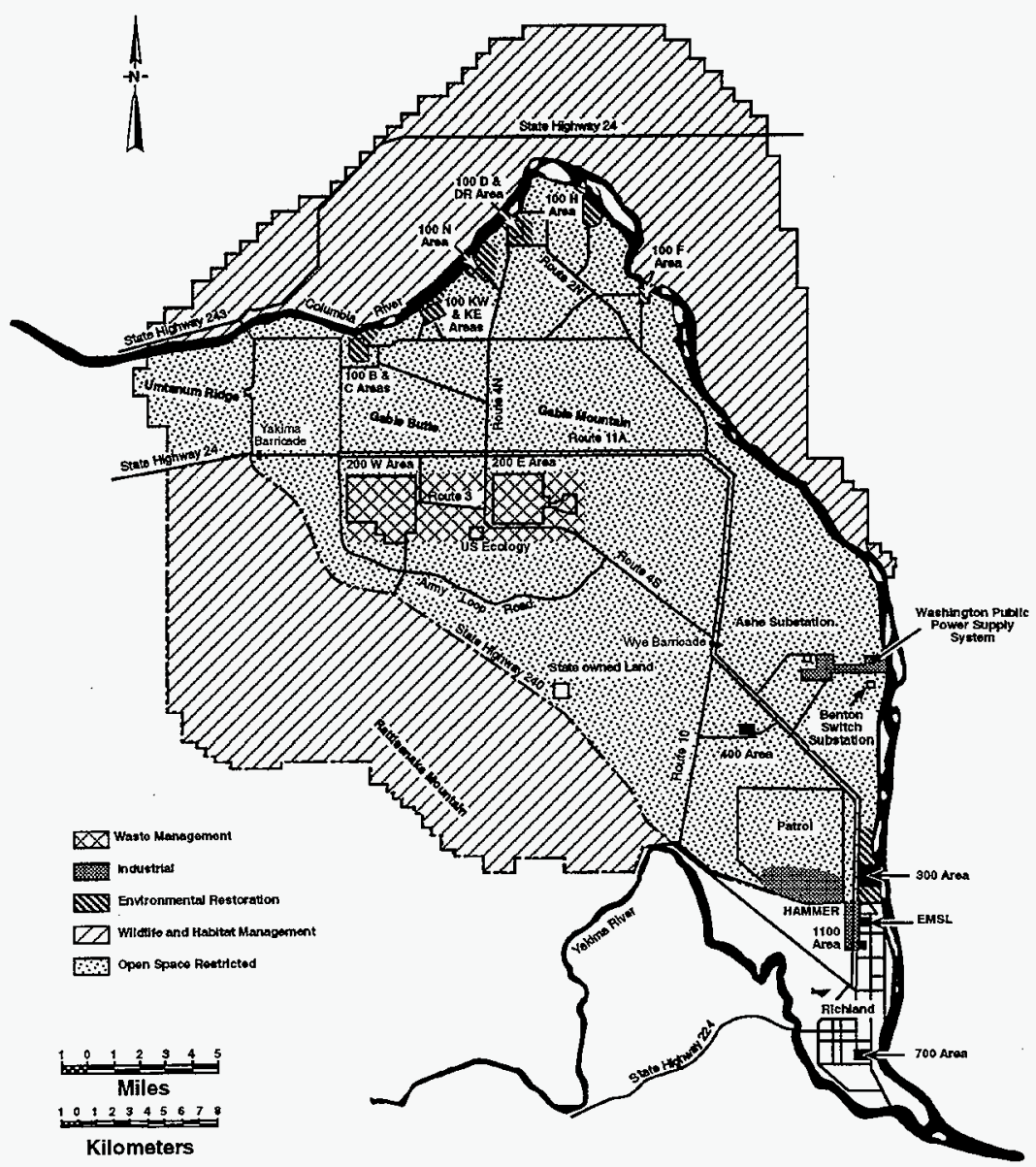

H97020271.3s

Figure 9-1. Land Uses at the Hanford Site (adapted from DOE/EIS-0222). 


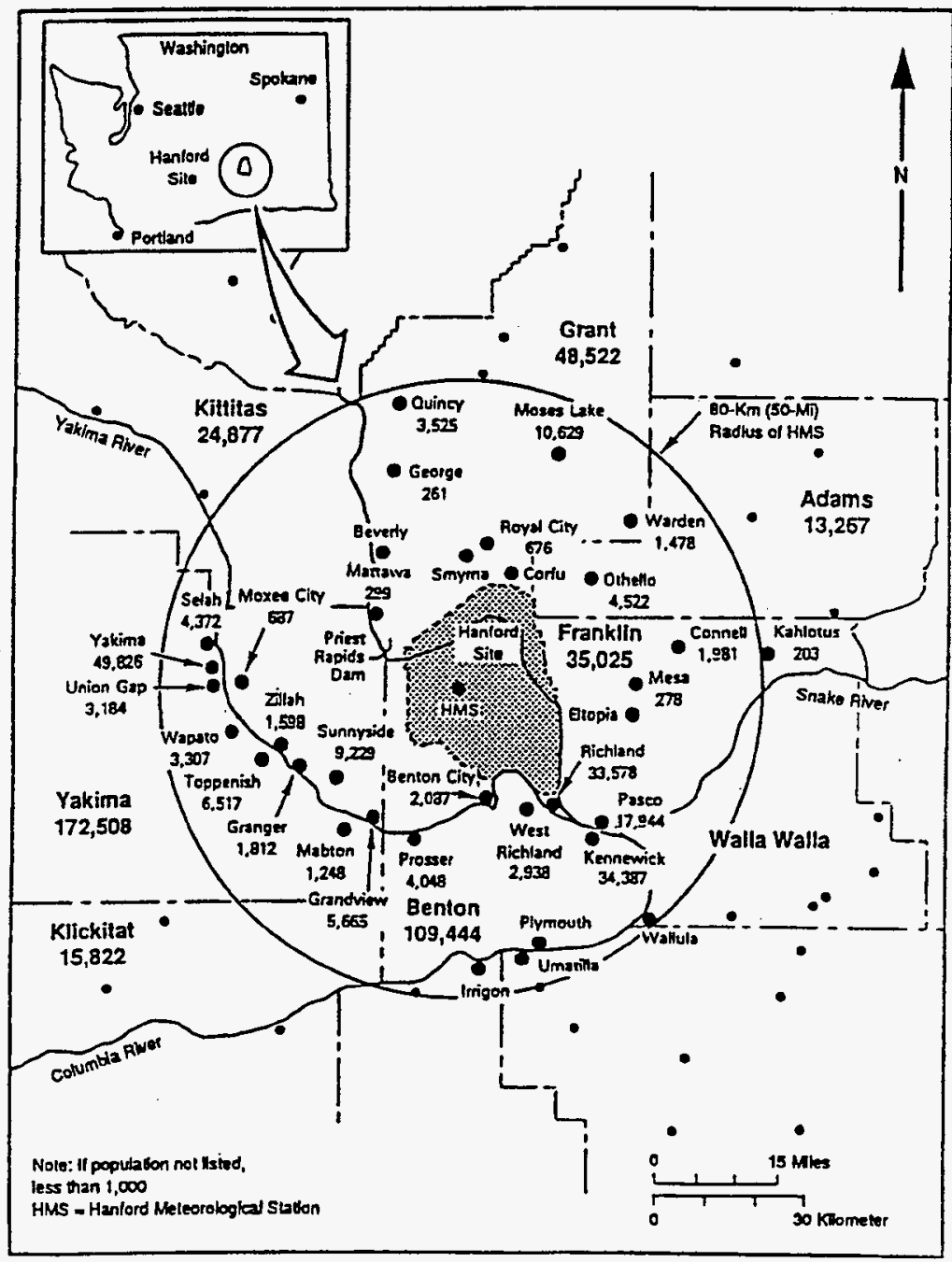

ACP $7903-738$ (AN. 1290)

Figure 9-2. Population in the Vicinity of the Hanford Site. 
Table 9-1. Information Requirements Checklist. (sheet 1 of 11)

3 1. General Information

4

5 Reg. cited

Description

Location in

permit

Other/

application $^{\mathrm{a}}$

comments

\begin{tabular}{lllr}
6 & $270.14(\mathrm{~b})(1)$ & General description of facility & 2.0 \\
\cline { 2 - 3 } 7 & 270.14(b) (2) & Chemical and physical analyses of wastes & 3.0
\end{tabular}

8 and (3)

9 270.14(b)(4) Access control and security description of active portion $\quad 6.0$

$10270.14(\mathrm{~b})(5)$

$11270.17(d)$, and

$12 \quad 270.21$ (d)

$\stackrel{0}{\square}$

$270.14(\mathrm{~b})(6)$

$14270.14(\mathrm{~b})(7)$

Preparedness and prevention documentation

6.0

$5270.14(\mathrm{~b})(8)$

Contingency plan

7.0 Appendix 7A

$16270.14(\mathrm{~b})(11)$

Preventive procedures

Appendix 7A

17 (i) and (ii)

$18 \quad 270.14(\mathrm{~b})(13)$

Facility location information

2.0

Closure plan

11.0

19

20

21 
Table 9-1. Information Requirements Checklist. (sheet 2 of 11)

3 1. General Information (continued)

Location in permit

application $^{8}$

5 Reg. cited

Description

$6270.14(b)(13) \quad$ Postclosure care plan 11.0

$7270.14(\mathrm{~b})(17)$

Documentation of insurance

N/A

$8 \quad 270.14(\mathrm{~b})(19)$

Topographic map (site plotted on U.S. Geological Survey Appendix 2A quadrangle maps)

$9 \quad 270.21(a)$ and

$10 \quad 270.17(a)$

List of waste placed or to be placed in each unit

1.0

11 Additional Information

넘 12

13

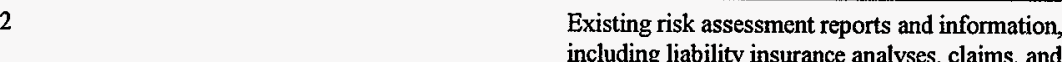

9.0 settlements

Land use and zoning map(s) for an area of four miles

9.0 around the unit

14

Existing aerial photographs of the facility

Appendix 2A

15

16 
Table 9-1. Information Requirements Checklist. (sheet 3 of 11)

2

3 1. General Information (continucd)

4

5

6 Additional Information (continued)

7

.

8

\begin{tabular}{|c|c|c|c|}
\hline 9 & & $\begin{array}{l}\text { Identification of any federal, state, or local inspection or } \\
\text { compliance records related to environmental and health } \\
\text { programs, include descriptions of any major violations }\end{array}$ & $\begin{array}{l}9.0 \\
12.0\end{array}$ \\
\hline 10 & 2. Groundwater Pathway & & \\
\hline 11 & $270.14(c)(1)$ & Interim status groundwater monitoring results & 5.0 \\
\hline 12 & $270.14 .(\mathrm{c})(2)$ & $\begin{array}{l}\text { Identification of uppermost aquifer, including flow rate and } \\
\text { direction }\end{array}$ & 5.0 \\
\hline
\end{tabular}

Identify and summarize any waste analysis data not already $\quad 3.0$ submitted; provide additional data as discussed in text

Current estimate of annual amount of waste

received and description of any pretreatment process used $\quad 1.0$

3.0

4.0

Location in

permit

application ${ }^{2}$

Other/

comments

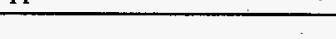

13

14 
Table 9-1. Information Requirements Checklist. (sheet 4 of 11)

3 2. Groundwater Pathway (continued)

4

5 Reg. cited

Description

Location in

permit

Other/

$6270.14(c)(3)$

7 and

$8 \quad 270.14(\mathrm{~b})(19)$

Topographic maps related to groundwater protection (well 5.0

location, water table elevation contours, etc.)

application $^{\mathrm{a}}$

comments

$9270.14(\mathrm{c})(4)$

Description of existing contamination

Appendix 2A

10 (i) and (ii)

\begin{tabular}{llll}
\hline $270.14(\mathrm{c})(5)$ & Detailed plans for groundwater monitoring program & 5.0 \\
\hline 22 & Description of detection monitoring program (if applicable) & 5.0
\end{tabular}

$13270.14(\mathrm{c})(7) \quad$ Description of compliance monitoring program and

부 14 and (c)(7)(ii) characterization of contaminated groundwater (if

$\stackrel{\oplus}{+}$ applicable)

\begin{tabular}{llll}
15 & $270.14(\mathrm{c})(7)(\mathrm{iv})$ & Alternate concentration limits demonstration (if any) & \\
\cline { 2 - 4 } 16 & $270.14(\mathrm{c})(8)$ & Corrective action program (if applicable) & N/A \\
\cline { 2 - 4 } 17 & $270.17(\mathrm{~b})(1)$ & $\begin{array}{l}\text { Description of liner and leachate collection systems (if } \\
\text { applicable) }\end{array}$ & 4.0 \\
18 & $270.21(\mathrm{~b})(1)$ & N/A & \\
\cline { 2 - 5 }
\end{tabular}

19

20 
Table 9-1. Information Requirements Checklist. (sheet 5 of 11)

3 2. Groundwater Pathway (continued)

4

5 Reg. cited

Location in

permit

Other/

6

Description

application $^{2}$

comments

Additional Information

7

Existing map showing location of all known wells within 3 Appendix $2 \mathrm{~A}$

miles; number and location

of drinking water wells

8

Discussion of groundwater uses within 3 miles of unit

5.0

Regional map showing areas of groundwater recharge and

9.0

9 discharge

损 10

Net precipitation using net seasonal rainfall or other

2.0

available data

5.0

9.0

11

Unless otherwise reported to EPA, available well data indicating a release, and information on any affected public or private water supplies, including populations served

Any known food chain contamination resulting from prior release from the unit to groundwater

12

13

14 
Table 9-1. Information Requirements Checklist. (sheet 6 of 11)

3 3. Surface Water Pathway

4

5 Reg. cited

Location in

Other/

permit

Other/

270.14(b)(11)

Location information related to 100 -year floodplain application $^{\mathrm{a}}$

7 (iii) through (v) including variance demonstrations

$8 \quad 270.21(b)(2)$

System for control of run-on from each peak discharge of

2.0 25-year storm

$270.21(b)(3)$

System for control of run-off from 24-hour, 25-year storm

2.0

4.0

$10 \quad 270.17(b)(2)$

Procedures/equipment to prevent overtopping

2.0

$(3)$

Structural integrity of dikes

4.0

$\frac{1}{6}$

$270.17(b)(3)$

2.0

4.0

12 Additional Information

13

Discussion of surface-water uses within 3 miles of the unit, $\quad 5.0$

including a map showing the location of all surface-water

9.0

bodies

Appendix 2A

and downstream drinking water intakes

14

Velocities of streams and rivers passing through and adjacent to the property

15 
Table 9-1. Information Requirements Checklist. (sheet 7 of 11)

\begin{tabular}{|c|c|c|c|}
\hline $\begin{array}{l}\text { 3. Surface Water Pathway (continued) } \\
\text { Reg. cited }\end{array}$ & Description & $\begin{array}{l}\text { Location in } \\
\text { permit } \\
\text { application" }\end{array}$ & $\begin{array}{l}\text { Other/ } \\
\text { comments }\end{array}$ \\
\hline \multicolumn{4}{|l|}{ Additional Information (continued) } \\
\hline & $\begin{array}{l}\text { Description of any system used to monitor surface- } \\
\text { water quality, and a summary of the data }\end{array}$ & 9.0 & \\
\hline & $\begin{array}{l}\text { Any known food chain contamination resulting from } \\
\text { prior release from the unit to surface water. }\end{array}$ & & None \\
\hline \multicolumn{4}{|l|}{ 4. Air Pathway } \\
\hline $270.21(b)(5)$ & $\begin{array}{l}\text { Plans to control wind dispersal of particulate matter at } \\
\text { landfills }\end{array}$ & $\begin{array}{l}4.0 \\
11.0\end{array}$ & \\
\hline
\end{tabular}

16 
Table 9-1. Information Requirements Checklist. (sheet 8 of 11)

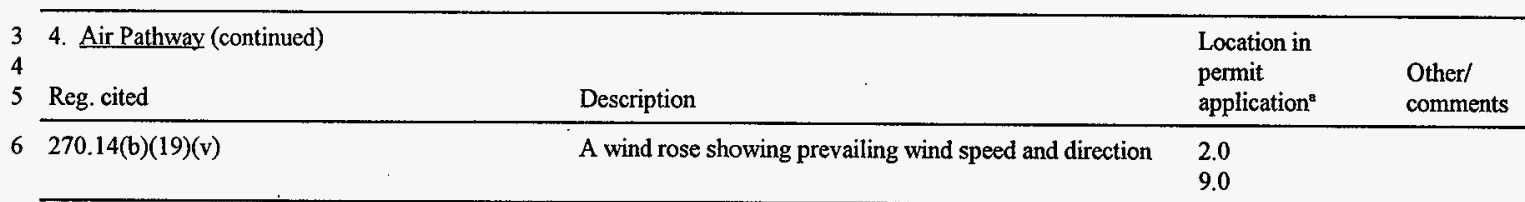

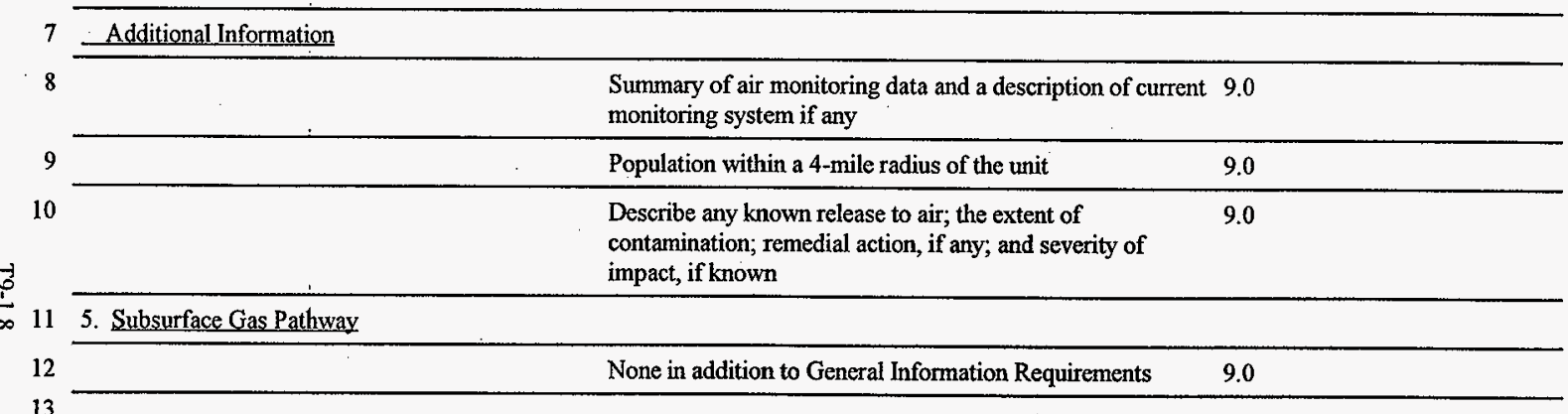


Table 9-1. Information Requirements Checklist. (sheet 9 of 11)

3 5. Subsurface Gas Pathway (continued)

4 Reg. cited

Description

Location in

permit

Other/

application $^{\mathrm{a}}$

comments

\section{Additional Information}

6 Any past disposal of municipal-type wastes in the unit; approximate quantities and dates of disposal, if known

None

7

Map location of any underground conduits within the site Appendix 2A and known underground conduits within 1,000 feet of property boundary

\begin{tabular}{|c|c|c|c|c|}
\hline 8 & & $\begin{array}{l}\text { Descriptions of any monitoring or control mechanisms for } \\
\text { subsurface gas release; summarize resulting data }\end{array}$ & & None \\
\hline 9 & & $\begin{array}{l}\text { Description of any known releases; extent of } \\
\text { contamination; remedial action taken, if any; and the } \\
\text { severity of impact, if known }\end{array}$ & & None \\
\hline 10 & 6. Contaminated Soil Pathway & & & \\
\hline 11 & & None in addition to General Information Requirements & 9.0 & \\
\hline
\end{tabular}


Table 9-1. Information Requirements Checklist. (sheet 10 of 11)

3 6. Contaminated Soil Pathway (continued)

4 Reg. cited

Location in permit application $^{\mathrm{a}}$

Other/ comments

5 Additional Information

6 If soil sampling has been done, a map showing areas

of soil contamination, and a summary of analytical

results

Description of the types of major releases that resulted

in soil contamination, and any cleanup action

Any known food chain contamination resulting from

the use of contaminated soils for raising crops

$\begin{array}{rrr}\text { 它 } & 9 & \text { 7. Transportation Information } \\ \text { : } & 10 & 270.14(\mathrm{~b})(10)\end{array}$

Traffic pattern, volume, and controls; access road

2.0

characteristics

11 Additional Information

12

Description of the types and capacities of vehicles used to transport waste

None

None

None

used to transport waste

13 
Table 9-1. Information Requirements Checklist. (sheet 11 of 11)

3 7. Transportation Information (continued)

4

5 Reg. cited

Description

Location in

permit

Other/

6 Additional Information (continued)

7

Identification of normal transport routes for hazardous waste into

2.0

the site and within 1 mile of the facility entries

8

Description of procedures for cleanup of transportation-related spills or leaks

7.0

9 Descriptions of any transportation accidents releasing hazardous None

Appendix 7A

wastes onsite, or in the immediate vicinity

10 8. Management Practices Information

으 $11270.14(\mathrm{~b})(12)$

: $12 \quad 264.16$

Outline of programs to train employees to safely operate and

8.0

13

14

- Location in Hanford Facility Dangerous Waste Permit Application (i.e., DOE/RL-91-28, and/or DOE/RL-88-20, and/or DOE/RL-93-03).

16

17

${ }^{b}$ N/A--Not Applicable.

18 
DOE/RL-91-28, Rev. 4

05/98

This page intentionally left blank. 
DOE/RL-91-28, Rev. 4

$05 / 98$

\section{CONTENTS}

2

3

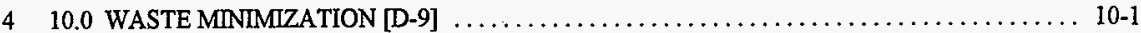
5

6 
DOE/RL-91-28, Rev. 4

$05 / 98$

This page intentionally left blank. 


\subsection{WASTE MINIMIZATION [D-9]}

2

3

4

5

6

7

8

9

10

This chapter addresses the provisions identified in Section D-9 of Ecology's permit application guidance (Ecology 1987 and 1996). This chapter also addresses Condition II.F. (Waste Minimization) of the HF RCRA Permit (HSWA Portion). To fulfill the requirements of 40 CFR 264.73(b)(9), and Condition II.F. of the HF RCRA Permit (HSWA Portion), onsite generating units complete a waste minimization/pollution prevention certification annually certifying that a waste minimization/pollution prevention program is in place. A copy is maintained in the Hanford Facility Operating Record, Unit-Specific file (refer to Chapter 12.0, Section 12.1.43). 
This page intentionally left blank. 
11.0 CLOSURE AND FNANCIAL ASSURANCE []

11.1 CLOSURE PLAN/FINANCIAL ASSURANCE FOR CLOSURE $[1-1] \ldots \ldots \ldots \ldots \ldots 11-1$

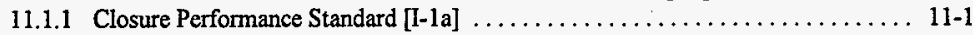

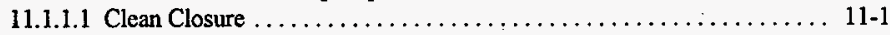

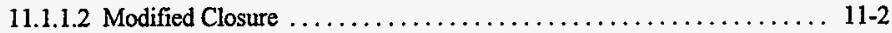

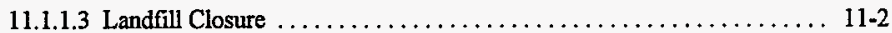

11.1.1.4 Standards ................................... 11-3

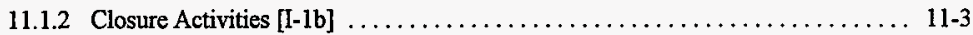

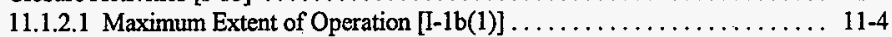

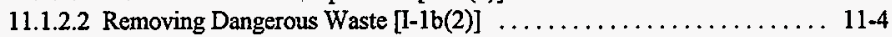

11.1.2.3 Decontamination Structures, Equipment, and Soil [I-1b(3)] . . . . . . 11-4

11.1.2.4 Sampling and Analysis to Identify Extent of Decontamination/Removal and to Verify Achievement of Closure Standard [1-1b(4)] . . . . . . 11-4

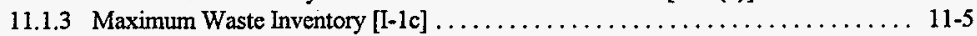

11.1.4 Closure of Waste Piles, Surface Impoundments, Incinerators, Land Treatment, and Miscellaneous Units [I-1d] . . . . . . . . . . . . 11-5

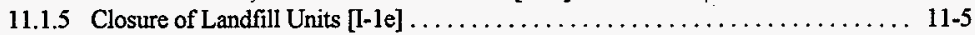

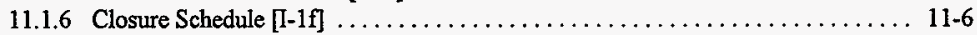

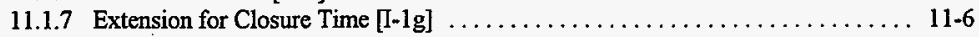

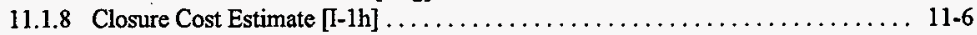

11.1.9 Financial Assurance Mechanism of Closure $[1-1 \mathrm{i}] \ldots \ldots \ldots \ldots \ldots \ldots \ldots \ldots \ldots \ldots$

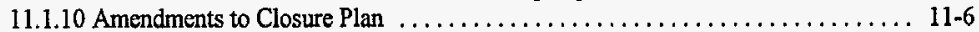

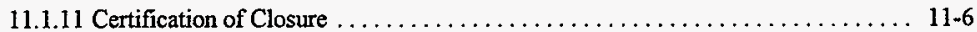

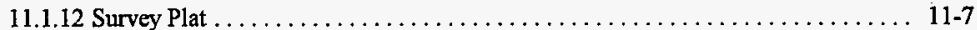

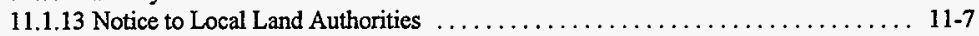

11.2 NOTICE IN DEED OF ALREADY CLOSED DISPOSAL UNITS $[1-2] \ldots \ldots \ldots \ldots \ldots$

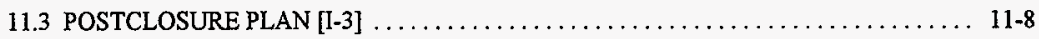

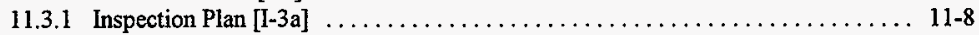

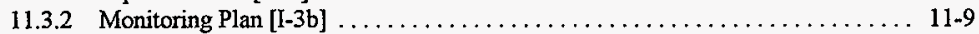

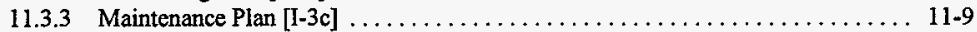

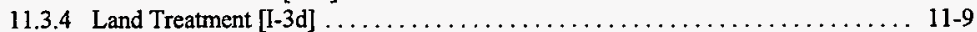

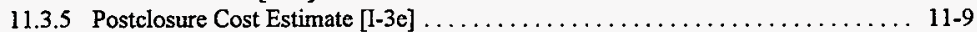

11.3.6 Financial Assurance Mechanism for Postclosure Care $[1-3 f] \ldots \ldots \ldots \ldots \ldots \ldots$. $11-9$

11.3.7 Provisions to Amend Postclosure Plan . . . . . . . . . . . . . . . . . .

11.3.8 Certification of Completion of Postclosure Care $\ldots \ldots \ldots \ldots \ldots \ldots \ldots \ldots \ldots$

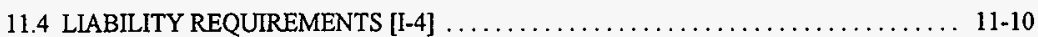

11.5 CLOSURE OF THE HANFORD FACILITY $\ldots \ldots \ldots \ldots \ldots \ldots \ldots \ldots \ldots \ldots \ldots$

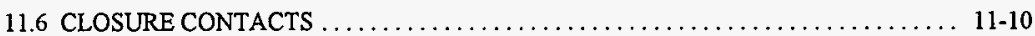


DOE/RL-91-28, Rev. 4 $05 / 98$

FIGURE

3

4

11-1. General Closure Flow Chart .

F11-1 


\subsection{CLOSURE AND FINANCIAL ASSURANCE [I]}

This chapter addresses the provisions contained in Section I of Ecology's permit application guidance (Ecology 1987 and 1996) and in Conditions II.J. (Facility Closure) and II.K. (Soil/Groundwater Closure Performance Standards) of the HF RCRA Permit (DW Portion). Although the content of this chapter focuses on 'operating units', most of the information also is applicable to TSD units 'undergoing closure'. Detailed information on closure activities associated with TSD units 'undergoing closure' is addressed in unit-specific preclosure work plans, closure work plans, closure plans, closure/postclosure plans, or postclosure permit application documentation. Additional information applicable to TSD units 'undergoing closure', particularly information that pertains to RCRA/CERCLA integration, is contained in Chapter 2.0, Section 2.5.

Cross-reference is made to Chapter 2.0 , Section 2.5 , where portions of this section also could be applicable to 'operating' TSD units.

When a TSD unit is no longer used to treat, store, and/or dispose of dangerous or mixed waste, this TSD unit will be closed. Closure will be accomplished in a manner that is protective of human health and the environment, and will be conducted in accordance with current regulations. The term 'RCRA closure', as used in this chapter, refers to consideration of both federal and state regulations as applicable.

\subsection{CLOSURE PLAN/FINANCIAL ASSURANCE FOR CLOSURE [I-1]}

As specified in Condition II.K. of the HF RCRA Permit (DW Portion), there are three RCRA closure options: clean closure, modified closure, and landfill closure. Specific closure activities and objectives for any one TSD unit will be included in the Unit-Specific Portion of this permit application or in preclosure work plan, closure work plan, closure plan, closure/postclosure plan, or postclosure permit application documentation. Figure 11-1 shows a general closure flow chart addressing the three RCRA closure options.

\subsubsection{Closure Performance Standard [I-1a]}

The following sections address the three closure options cited in Condition II.K. of the HF RCRA Permit (DW Portion): clean closure, modified closure, and landfill closure. Modified closure and landfill closure options also can be used to accommodate RCRA/CERCLA integration needs. As noted in Chapter 2.0, Section 2.5 , nearly all TSD units are located within a RCRA or CERCLA operable unit.

11.1.1.1 Clean Closure. Clean closure is accomplished when cleanup levels as prescribed in WAC 173-303-610(2)(b) have been achieved. Conditions II.K.1. and II.K.2. of the HF RCRA Permit (DW Portion) specifically address clean closure. Clean closure is accomplished by verifying that the potentially dangerous constituents treated, stored, and/or disposed at the TSD unit being closed are not present above cleanup levels for those potential contaminants.

As required by WAC 173-303-610(2)(b), cleanup levels will be based on equations and exposure assumptions presented in WAC 173-340, MTCA for residential exposure (Method B). For noncarcinogens, the principal variable relating human health to cleanup levels will be the oral reference dose (Appendix 2B). For carcinogens, the cancer slope factor will be the basis for determining human health effects and is a measurement of risk per unit dose. The oral reference dose and cancer slope factor are chemical specific and 
1 are obtained from the Integrated Risk Information System (IRIS) database (EPA 1989a). Cleanup levels will

2 be based on values that are current at the time of approval of closure documentation.

Protection of human health and the environment will be accomplished by removing or treating all dangerous waste constituents at a TSD unit to concentration levels that are not a threat to human health and the environment. However, remediation will not be below background levels, as approved by Ecology, if these background levels are above MTCA Method B levels.

11.1.1.2 Modified Closure. If dangerous waste constituents present at the TSD unit are above MTCA Method B levels, but below MTCA Method C levels (industrial-based scenario), then a 'modified' closure option could be used (refer to Chapter 2.0, Section 2.5). Requirements for a modified closure are specified in Condition II.K.3 of the HF RCRA Permit (DW Portion). These requirements include the following:

- Provision of institutional controls in accordance with WAC 173-303-440 for a minimum of 5 years

- Conduct of periodic assessments of the TSD unit to determine the effectiveness of the closure

- Development of a postclosure permit application, including final status postclosure groundwater monitoring

- Selection of a clean-up option with consideration of the potential future site use for that TSD unit/area.

11.1.1.3 Landfill Closure. A landfill closure occurs when dangerous waste constituents are left at the TSD unit in concentrations that are above MTCA Method C levels (refer to Chapter 2.0, Section 2.5). When waste or contamination is left in place, the submittal of postclosure documentation is required. This documentation would contain a RCRA-compliant landfill cover design and a postclosure monitoring plan. The postclosure monitoring plan would describe how the covered TSD unit would be monitored and maintained to ensure protection of human health and the environment. Regulations require monitoring and maintenance for at least 30 years unless a shorter time is approved by Ecology (the shorter time must be shown to be sufficient to protect human health and the environment). Requirements for a landfill closure are contained in WAC 173-303-610 and Condition II.K.4. of the HF RCRA Permit (DW Portion).

Condition II.K.6. of the HF RCRA Permit (DW Portion) allows deviations from a TSD unit closure plan required by unforseen circumstances encountered during closure activities that do not impact the overall closure strategy. These deviations must provide equivalent results and are to be documented in the Hanford Facility Operating Record, Unit-Specific File.

Condition II.K.7. of the HF RCRA Permit (DW Portion) allows, when agreed to by Ecology, integration of other statutorily or regulatory mandated cleanups. The results from other cleanup investigation activities could be used whenever possible to supplement and/or replace TSD unit closure investigation activities. All, or appropriate parts of, multipurpose cleanup and closure documents could be incorporated into the HF RCRA Permit (DW Portion) through the permit modification process. Cleanup and closures conducted under any statutory authority with oversight by either Ecology or EPA, which meets the equivalent of the technical requirements of Condition II.K. of the HF RCRA Permit (DW Portion), could be considered as satisfying the requirements of the HF RCRA Permit (DW Portion). Thus, Condition II.K.7. of the 
1 HF RCRA Permit (DW Portion) is particularly key in promoting RCRA/CERCLA integration on the Hanford 2 Facility, as discussed in Chapter 2.0, Section 2.5.

11.1.1.4 Standards. The following sections address closure performance standards and waste removal and decontamination standards.

All plans will be developed to close TSD units in a manner that meets the closure performance standards of WAC 173-303-610(2):

"(a)(I) Minimizes the need for further maintenance;

(ii) Controls, minimizes or eliminates to the extent necessary to protect human health and the environment, postclosure escape of dangerous waste, dangerous constituents, leachate, contaminated run-off, or dangerous waste decomposition products to the ground, surface water, ground water, or the atmosphere; and

(iii) Returns the land to the appearance and use of surrounding land areas to the degree possible given the nature of the previous dangerous waste activity."

11.1.1.1 Minimizing the Need for Future Maintenance. Minimizing the need for future maintenance will be accomplished by clean closing (at or below health-based standards) TSD units whenever possible. Clean closure will eliminate the need for future maintenance. In areas where clean closure cannot be achieved, future maintenance needs will be addressed in unit-specific postclosure documentation.

11.1.1.4.2 Protection of Human Health and the Environment. Protection of human health and the environment will be accomplished by removing or treating all dangerous waste constituents at a TSD unit to concentration levels that are not a threat to human health and the environment. If dangerous waste constituents cannot be removed or treated to levels that are protective of human health and the environment and must be left in place, a RCRA-compliant landfill cover will be installed. Regulations require monitoring and maintenance for at least 30 years unless a shorter time is approved by Ecology (the shorter time must be shown to be sufficient to protect human health and the environment).

Cleanup levels will be established using guidance such as WAC 173-340, the IRIS database (EPA 1989a), Risk Assessment Guidance for Superfund: Human Health Evaluation Manual (EPA 1989b), the Hanford Site Baseline Risk Assessment Methodology (DOE/RL-91-45), and other appropriate information.

11.1.1.4.3 Return Land to the Appearance and Use of Surrounding Land. Closure plans will include, to the extent practicable, consideration of returning the TSD units to an appearance compatible with surrounding structures and/or the semi-desert terrain of the area.

\subsubsection{Closure Activities [I-1b]}

The activities undertaken or planned to perform closure for a TSD unit are identified in the Unit-Specific Portion of this permit application or in preclosure work plan, closure work plan, closure plan, closure/postclosure plan, or postclosure permit application documentation. General closure activity 
1 information is discussed in the following sections. Of particular relevance in the definition of closure

2 activities is the use of the DQO process (refer to Chapter 3.0, Section 3.2).

11.1.2.1 Maximum Extent of Operation [I-1b(1)]. During the waste investigations to determine the maximum extent of operations, the TSD unit-specific closure plans will ensure that the waste is characterized properly in terms of presence, location, concentration, and volume of each contaminant. Research of process records, drawings, and photographs will shape the initial sampling strategy. As field information and laboratory results become available, the sampling strategy could specify more sampling until the waste contaminants can be reliably located and quantified. Information specific to any one TSD unit is included in the Unit-Specific Portion of this permit application or in preclosure work plan, closure work plan, closure plan, closure/postclosure plan, or postclosure permit application documentation.

11.1.2.2 Removing Dangerous Waste [I-1b(2)]. Before a non-land-based TSD unit can be closed, the dangerous waste will be removed and sent to a permitted TSD unit. Removal of the dangerous waste will be completed within 90 days after the last waste receipt at the unit unless a longer period is specified in the closure plan.

\subsubsection{Decontamination Structures, Equipment, and Soil [I-1b(3)]. The remediation process for a} TSD unit will be agreed upon with the appropriate regulatory agency(s) using one of the three closure options discussed in Sections 11.1.1.1, 11.1.1.2, and 11.1.1.3. The agreed upon closure option will include sampling to determine if clean closure is achievable unless landfill closure is selected. If some remediation is undertaken, the sampling results will be used to determine when the remediation effort has been completed. Information specific to any one TSD unit is included in the Unit-Specific Portion of this permit application or in preclosure work plan, closure work plan, closure plan, closure/postclosure plan, or postclosure permit application documentation.

\subsubsection{Sampling and Analysis to Identify Extent of Decontamination/Removal and to Verify Achievement of Closure Standard [I-1b(4)]. Most sampling will be accomplished according to} information contained in established environmental regulations and guidelines using the DQO process. This information has been used in developing protocols set forth in contractor procedures and in EPA SW-846. These protocols will be followed in obtaining and handling all samples. Field duplicate, equipment blank, and trip blank samples (Appendix 2B) will be taken as appropriate and analyzed as a check on field sampling procedures, cross-contamination of samples, contamination from sample handling, and laboratory contamination. Samples usually will be taken on intervals down to 0.91 meter for non-land disposal units. Sampling and analysis information is provided in the SAP for a particular TSD unit. Discussion of the manner by which a SAP supports closure plan or closure/postclosure plan activities is contained in Chapter 3.0, Section 3.5.1.

The analytical data obtained from the sampling of each TSD unit will be vaiidated to a level agreed upon in the DQO process. The resulting concentration levels of the identified constituents will be compared with the corresponding MTCA Method B levels as agreed to by Ecology. If this comparison supports the conclusion that the area does not contain greater concentrations than cleanup levels for each constituent, the area will be cleaned closed. If sample results from a particular TSD unit do not meet the closure criteria, the particular waste constituents that exceed the cleanup levels will be identified, and further evaluations of the potential success of additional decontamination/removal efforts will be limited to these constituents. This information is documented in a data evaluation report. Discussion of the manner by which a data evaluation report supports closure plan or closure/postclosure plan activities is contained in Chapter 3.0, Section 3.5.2. 
Sampling and analysis of materials that are not covered by EPA SW-846 will be achieved using protocols, procedures, and methods approved by the appropriate regulatory agency(s) before conducting the sampling or analytical work. A description of procedures currently used to support closure activities, as well as the specific sampling plan, are included in the Unit-Specific Portion of this permit application or in preclosure work plan, closure work plan, closure plan, closure/postclosure plan, or postclosure permit application documentation.

\subsubsection{Maximum Waste Inventory [I-1c]}

An estimate of the maximum inventory of dangerous and/or mixed waste ever in storage and in treatment at any time during the active life of the TSD unit will be provided in the Unit-Specific Portion of this permit application or in preclosure work plan, closure work plan, closure plan, closure/postclosure plan, or postclosure permit application documentation.

\subsubsection{Closure of Waste Piles, Surface Impoundments, Incinerators, Land Treatment, and Miscellaneous Units [I-1d]}

Each unit-specific closure plan is uniquely designed for closure of that unit. Any additional closure criteria that are necessary because of the type of TSD unit, i.e., containment building, surface impoundment, land treatment, or miscellaneous unit, will be incorporated into the closure plan. The closure plan will be implemented when approval is received from Ecology and the EPA, and after the final waste receipt by the TSD unit.

The closure plan will contain information on closure performance standards, decontamination, waste inventory removal, sampling and analysis, schedule, and closure certification. Where possible, the closure plan will be prepared using clean closure as the basis for closing the TSD unit.

\subsubsection{Closure of Landfill Units [I-1e]}

Landfill units generally will be closed with waste left in-place, which precludes clean closure. Besides the closure information specified in Section 11.1.4, additional information will be provided in the following areas:

- Disposal Impoundments [I-e(1)]

- Elimination of Liquids [I-e(l)(a)]

- Waste Stabilization [I-e(1)(b)]

- Cover Design [I-le(2)]

- Minimization of Liquid Migration [I-Ie(3)]

- Maintenance Needs [I-le(4)]

- Drainage and Erosion [I-1e(5)]

- Settlement and Subsidence [I-1e(6)]

- Cover Permeability [1-le(7)]

- Freeze/Thaw Effects [I- Ie(8)]. 

A barrier or cover

\subsubsection{Closure Schedule [I-1f]}

In accordance with regulations, closure activities will commence following the final receipt of waste. The TSD unit-specific schedule for closure will be provided in the closure plan. The activities to complete closure will be scheduled within 180 days unless a modified schedule is presented and agreed upon in the closure plan.

\subsubsection{Extension for Closure Time [I-1g]}

If closure activities will exceed the approved closure plan schedule, closure time extensions will be requested. All extension requests will include the justification for the extension and details for the remaining activities to achieve closure.

\subsubsection{Closure Cost Estimate [I-1h]}

Condition II.H.3. of the HF RCRA Permit (DW Portion) specifies that the "Permittees are exempt from the requirements of WAC 173-303-620." However, the Permittees have agreed to provide, annually, projections of anticipated costs for closure and postclosure for TSD units incorporated into Parts III or V of the HF RCRA Permit (DW Portion) (refer to Chapter 12.0, Section 12.1.22). Submittal of this annual report will take place on October 31 of each year, as described in Condition II.H.1. of the HF RCRA Permit (DW Portion).

\subsubsection{Financial Assurance Mechanism of Closure [I-1i]}

Federal facilities, and government contractors at such facilities, are not required to comply with WAC 173-303-620 as stated in the regulation and as described in Condition II.H.3. of the HF RCRA Permit (DW Portion).

\subsubsection{Amendments to Closure Plan}

Should changes be required to the approved closure plan, an amended plan will be prepared and submitted to the proper regulatory agency(s) for approval in accordance with 40 CFR 264.112(c) and WAC 173-303-610(3)(b).

\subsubsection{Certification of Closure}

Within 60 days of final closure of any TSD unit, the DOE-RL will submit a certification of closure to the proper regulatory agency(s) in accordance with 40 CFR 264.115 and WAC 173-303-610(6). This

certification will be signed by both the Permittees and by an independent professional engineer, and will state 
that the TSD unit has been closed in accordance with the approved closure plan. The certification will be submitted by registered mail or an equivalent delivery service. Documentation supporting the closure certification will be retained and will be furnished upon request to the proper regulatory agency(s). This documentation will be maintained by the DOE-RL contact (or the successor) identified in Section 11.6; a record also will be maintained in the Hanford Facility Operating Record (refer to Chapter 12.0, Section 12.1.32). According to condition II.J. of the HF RCRA Permit, final closure of the Hanford Facility will be achieved when closure activities for all TSD units have been completed, as specified in Parts III, IV, or $\mathrm{V}$ of this Permit. Completion of these activities will be documented using either certifications of closure, in accordance with WAC 173-303-610(6), or certifications of completion of postclosure care, in accordance with WAC 173-303-610(11).

\subsubsection{Survey Plat}

On submission of the closure certification for a land disposal unit, a survey plat indicating the location and dimensions of the unit will be submitted to the following:

- Benton County Land Planning Department

- The EPA and Ecology.

The survey plat will be prepared and certified by a professional land surveyor. The plat will contain a note that states the DOE-RL's obligation to restrict disturbance of the TSD unit. This submission will satisfy the requirements of 40 CFR 264.119(a) and WAC 173-303-610(9).

\subsubsection{Notice to Local Land Authorities}

To the extent that residual dangerous waste contamination (waste left-in-place) exceeds limits for protection of human health and the environment, the local land authority (county-specific land zoning board and engineer; refer to Chapter 12.0, Section 12.1.29) will be provided a certified legal description of the contaminant location and contaminant inventory.

\subsection{NOTICE IN DEED OF ALREADY CLOSED DISPOSAL UNITS [I-2]}

For those TSD units that cannot be clean closed, the following action will be taken in accordance with 40 CFR 264.119 and WAC 173-303-610(l)(b). Within 60 days of the certification of closure, the DOE-RL will sign, notarize, and file for recording the following notice. The notice will be sent to the Auditor of Benton County, P.O. Box 470, Prosser, Washington, with instructions to record this notice in the deed book.

\section{TO WHOM IT MAY CONCERN}

The United States Department of Energy, Richland Operations Office, an operations office of the United States Department of Energy, which is a department of the United States government, the undersigned, whose local address is the Federal Building, 825 Jadwin Avenue, Richland, Washington, hereby gives the following notice as required by 40 CFR 264.119 and WAC 173-303-610(10) (whichever is applicable): 
(a) The United States of America is, and since April 1943, has been in possession in fee simple of the following described lands: (legal description of the TSD unit).

(b) The United States Department of Energy, Richland Operations Office, by operation of the (name of TSD unit), has disposed of hazardous and/or dangerous waste under the terms of regulations promulgated by the United States Environmental Protection Agency and the Washington State Department of Ecology (whichever is applicable) at the above described land.

(c) The future use of the above described land is restricted under terms of 40 CFR 264.117(c) and WAC 173-303-610(7)(d) (whichever is applicable).

(d) Any and all future purchasers of this land should inform themselves of the requirements of the regulations and ascertain the amount and nature of wastes disposed on the above described property.

(e) The United States Department of Energy, Richland Operations Office, has filed a survey plat with the Benton County Planning Department and with the United States Environmental Protection Agency, Region 10, and the Washington State Department of Ecology (whichever are applicable) showing the location and dimensions of the (name of the TSD unit) and a record of the type, location; and quantity of waste treated.

\subsection{POSTCLOSURE PLAN [I-3]}

A postclosure plan will be submitted with the closure plan for land disposal TSD units (i.e., closure with dangerous waste constituents left in place above MTCA Level B cleanup levels). As discussed in Chapter 2.0, Section 2.5, documentation for these TSD units will be developed in accordance with Sections 5.5 and 6.3 of the Tri-Party Agreement Action Plan. These Tri-Party Agreement Action Plan sections require the submittal of a postclosure permit application. This postclosure permit application will contain much of the same information as supplied in the postclosure plan, the contents of which are to be discussed in the remainder of Section 11.3. Conditions resulting from the submittal of postclosure permit application documentation are to be incorporated into Part VI of the HF RCRA Permit (DW Portion) (refer to Chapter 2.0, Section 2.1.1.3.3).

\subsubsection{Inspection Plan [I-3a]}

The inspection plan will describe inspections to be conducted during the postclosure period, the frequency of inspections, the inspection procedures, and the logs to be kept. The inspection plan will contain information on the following items, as applicable: security control devices; erosion damage; cover settlement, subsidence, and displacement; vegetative cover condition; integrity of run-on and run-off control measures; cover drainage system; gas venting system; well condition; and benchmark integrity. 


\subsubsection{Monitoring Plan [I-3b]}

The monitoring plan will describe activities associated with groundwater monitoring during the postclosure period. The groundwater monitoring plan will contain the following information, as applicable: interim status period groundwater monitoring data, aquifer identification, contaminant plume description, detection monitoring program, compliance monitoring program, and corrective action program.

\subsubsection{Maintenance Plan [I-3c]}

The maintenance plan will describe the preventative and corrective maintenance procedures, equipment, and material needs. The plan will contain the following information, as applicable: repair of security control devices; erosion damage repair; correction of settlement, subsidence, and displacement; mowing, fertilization, and other vegetative cover maintenance; repair of run-on and run-off control structures; and well replacement.

\subsubsection{Land Treatment [I-3d]}

Land treatment information is concerned with the operations, inspections, and maintenance programs to be used at a TSD unit after closure. Of particular relevance at the Hanford Facility, will be programs and procedures implemented to maintain a vegetative cover and keep out deep-rooted plants and burrowing animals; minimize the damage due to wind erosion; and run-on and run-off management systems.

\section{1,3,5 Postclosure Cost Estimate [I-3e]}

Condition II.H.3. of the HF RCRA Permit (DW Portion) specifies that the "Permittees are exempt from the requirements of WAC 173-303-620." However, the Permittees have agreed to provide, annually, projections of anticipated costs for closure and postclosure and postclosure monitoring and maintenance for TSD units incorporated into Parts II, V, and VI of the HF RCRA Permit (DW Portion) (refer to Chapter 12.0, Section 12.1.22). Submittal of this annual report will take place on October 31 of each year, as described in Condition II.H.1. of the HF RCRA Permit (DW Portion).

\subsubsection{Financial Assurance Mechanism for Postclosure Care [I-3f]}

Federal facilities, and government contractors at such facilities, are not required to comply with WAC 173-303-620 as stated in the regulation and as described in Condition II.H.3. of the HF RCRA Permit (DW Portion).

\subsubsection{Provisions to Amend Postclosure Plan}

Should changes be required to approved postclosure plan documentation, amended documentation will be prepared and submitted to the proper regulatory agency(s) for approval in accordance with 40 CFR 264.1120 and WAC 173-303-610(3)(b). 


\subsubsection{Certification of Completion of Postclosure Care}

Within 60 days after completion of the established postclosure care period for each land disposal unit, the DOE-RL will submit to Ecology, by registered mail, a certification that the postclosure care period for the unit was completed in accordance with the approved postclosure plan. This certification will be signed by a representative of the DOE-RL and by an independent registered professional engineer. A record of this certification will be maintained in the Hanford Facility Operating Record (refer to Chapter 12.0, Section 12.1.32).

\subsection{LIABILITY REQUIREMENTS [I-4]}

Federal facilities, and government contractors at such facilities, are not required to comply with WAC 173-303-620 as stated in the regulation and as described in Condition II.H.3. of the HF RCRA Permit (DW Portion).

\subsection{CLOSURE OF THE HANFORD FACILITY}

Final closure of the Hanford Facility will be achieved when closure activities for all TSD units have been completed, as specified in either closure plan, closure/postclosure plan, or postclosure permit application documentation. Completion of these activities will be documented using either certifications of closure, in accordance with WAC 173-303-610(6), or certifications of completion of postclosure care, in accordance with WAC 173-303-610(11) as described in Condition II.J.1. of the Hanford RCRA Facility Permit (DW Portion). A discussion of the disposition of the Part A, Form 3 for a specific TSD unit that undergoes clean closure is included in Chapter 1.0.

\subsection{CLOSURE CONTACTS}

The following office (or its successor) is the official closure contact:

Environmental Assurance, Permits, and Policy Division

U.S. Department of Energy,

Richland Operations Office

P.O. Box 550

Richland, Washington 99352

(509) 376-5441. 


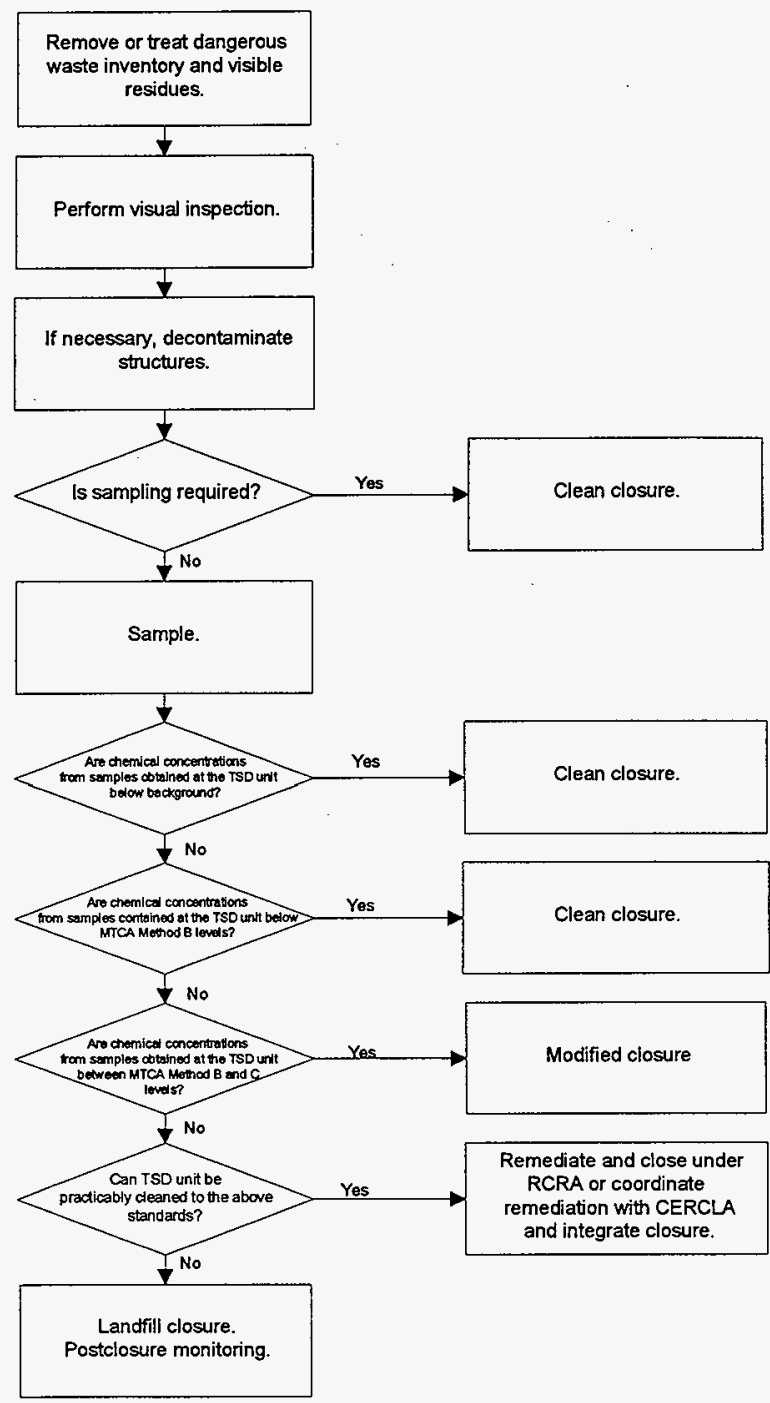

Figure 11-1. General Closure Flow Chart. 


\section{CONTENTS}

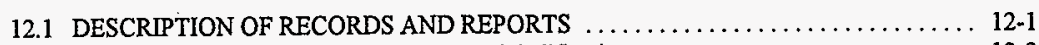

12.1.1 Quarterly Notification of Class 1 Modifications $\ldots \ldots \ldots \ldots \ldots \ldots \ldots \ldots \ldots, 12-2$

12.1.2 Monitoring and Records $\ldots \ldots \ldots \ldots \ldots \ldots \ldots \ldots \ldots \ldots \ldots \ldots \ldots \ldots \ldots \ldots \ldots \ldots, 12-2$

12.1.3 Reporting Planned Changes $\ldots \ldots \ldots \ldots \ldots \ldots \ldots \ldots \ldots \ldots \ldots \ldots \ldots \ldots \ldots \ldots \ldots \ldots, 12-2$

12.1.4 Certification of Construction or Modifications $\ldots \ldots \ldots \ldots \ldots \ldots \ldots \ldots \ldots \ldots \ldots, 12-2$

12.1.5 Anticipated Noncompliance $\ldots \ldots \ldots \ldots \ldots \ldots \ldots \ldots \ldots \ldots \ldots \ldots \ldots \ldots \ldots, 12-2$

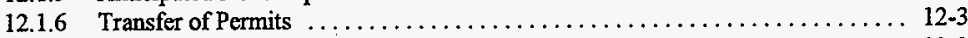

12.1.7 Immediate Reporting $\ldots \ldots \ldots \ldots \ldots \ldots \ldots \ldots \ldots \ldots \ldots \ldots \ldots \ldots \ldots \ldots \ldots \ldots \ldots \ldots, 12-3$

12.1.8 Release or Noncompliance Not Requiring Immediate Reporting $\ldots \ldots \ldots \ldots \ldots$ 12-3

12.1.9 Written Reporting $\ldots \ldots \ldots \ldots \ldots \ldots \ldots \ldots \ldots \ldots \ldots \ldots \ldots \ldots \ldots \ldots \ldots \ldots \ldots \ldots \ldots, 12-3$

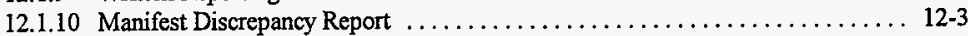

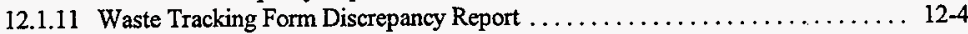

12.1.12 Other Information $\ldots \ldots \ldots \ldots \ldots \ldots \ldots \ldots \ldots \ldots \ldots \ldots \ldots \ldots \ldots \ldots \ldots \ldots \ldots, 12-4$

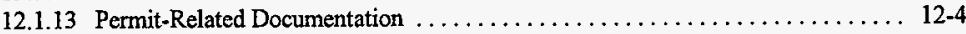

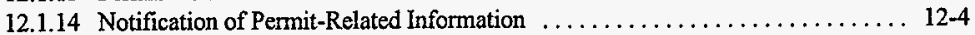

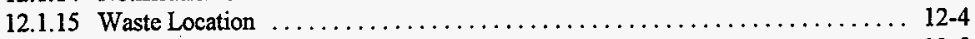

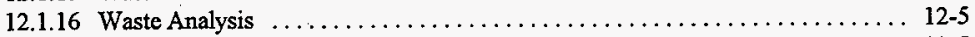

12.1 .17 Occurrence Reports $\ldots \ldots \ldots \ldots \ldots \ldots \ldots \ldots \ldots \ldots \ldots \ldots \ldots \ldots \ldots \ldots \ldots \ldots \ldots \ldots, 12-5$

12.1.18 Unmanifested Waste Reports $\ldots \ldots \ldots \ldots \ldots \ldots \ldots \ldots \ldots \ldots \ldots \ldots \ldots \ldots \ldots \ldots, 12-5$

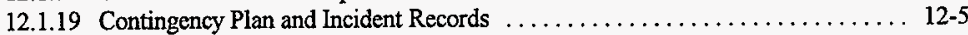

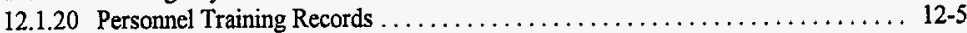

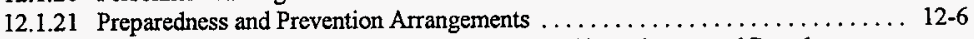

12.1.2 Projections of Anticipated Costs for Closure and Postclosure and Postclosure

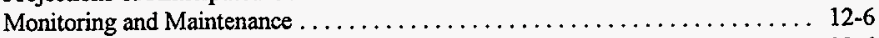

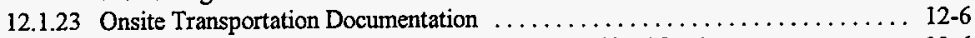

12.1.24 Cross-Reference of Waste Location to Waste Manifest Numbers . . . . . . . . 12-6

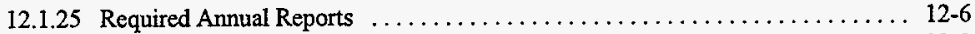

12.1.26 Groundwater Monitoring Records $\ldots \ldots \ldots \ldots \ldots \ldots \ldots \ldots \ldots \ldots \ldots \ldots \ldots \ldots \ldots, 12-8$

12.1.27 Groundwater Corrective Action $\ldots \ldots \ldots \ldots \ldots \ldots \ldots \ldots \ldots \ldots \ldots \ldots \ldots \ldots \ldots \ldots, 12-8$

12.1.28 Permit Condition Compliance Evaluation System $\ldots \ldots \ldots \ldots \ldots \ldots \ldots \ldots$ 12-8

12.1.29 Deed Notifications $\ldots \ldots \ldots \ldots \ldots \ldots \ldots \ldots \ldots \ldots \ldots \ldots \ldots \ldots \ldots \ldots \ldots \ldots, 12-8$

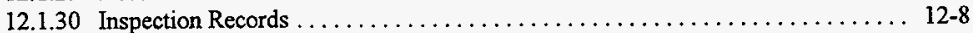

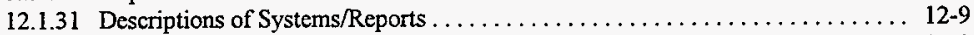

12.1.32 Closure Certification ................................... 12-9

12.1.33 Notification of, or Request for, a Permit Modification ................ 12-9

12.1.34 Closure Plan Deviation $\ldots \ldots \ldots \ldots \ldots \ldots \ldots \ldots \ldots \ldots \ldots \ldots \ldots \ldots . . .12-10$

12.1.35 Engineering Change Notices and Nonconformance Reports $\ldots \ldots \ldots \ldots \ldots$ 12-10

12.1.36 As-Built Drawings . . . . . . . . . . . . . . . . . . . . . . . . . . . . 12-10

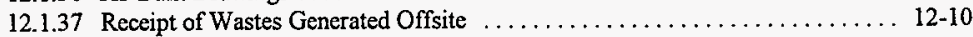

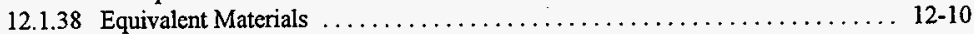

12.1.39 Land Disposal Restrictions Records ....................... 12-11

12.1.40 Mapping Methodology Report and Underground Pipline Maps .......... 12-11

12.1.41 Other Permit Compliance Documentation ...................... 12-11 
2

3

4

5

6

7

8

9

10

11

12

13

14

\section{CONTENTS (cont)}

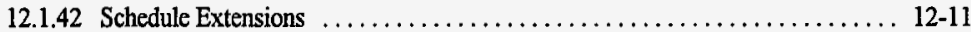

12.1.43 Waste Minimization/Pollution Prevention $\ldots \ldots \ldots \ldots \ldots \ldots \ldots \ldots \ldots$ 12-11

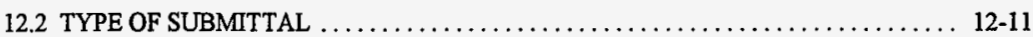

TABIE

12-1. Reports and Records

T12-1 


\subsection{REPORTING AND RECORDKEEPING}

2

3

4

This chapter discusses reporting and recordkeeping requirements as detailed in Condition II.I. (Facility Operating Record) (DW Portion), Condition I.L. (Monitoring and Records) (HSWA Portion), and other conditions of the HF RCRA Permit. Much of this discussion focuses on the organization and content of the Hanford Facility Operating Record and describes how records are managed and maintained. Certification and immediate reporting requirements also are discussed.

For purposes of maintaining records designated for the "Hanford Facility", the 700 Area and north to, and including, the Hanford Site is considered to meet the intent of WAC 173-303, even though the 700 Area is not located within the Hanford Facility boundary (Chapter 2.0, Figure 2-1). Because of the limitation of space, records could be archived, as appropriate, at the Federal Records Center, 6125 Sand Point Way, Seattle, Washington, 98115 , or other federal government archive centers in Washington State. Records located on the Hanford Facility, and stored at government archive centers, can be accessed by contacting the Environmental Data Management Center (509) 376-1418. The current approach is to retain records until 10 years after postclosure or corrective action is complete and certified for the Hanford Facility, whichever is later (Condition I.E.10.b. and I.E.10.c of the HF RCRA Permit [DW Portion]). As specified in the HF RCRA Permit (DW Portion), records can be kept in an electronic format (Conditions I.E.10.b., I.E. 10.c., and II.C.1.).

\subsection{DESCRIPTION OF RECORDS AND REPORTS}

Records and reports required by the HF RCRA Permit and associated WAC 173-303 and Title 40, Code of Federal Regulations are summarized briefly in this section. These summaries are keyed to Table 12-1, which lists Permit conditions and the associated records and/or reports, where located, and the mechanisms by which these records and/or reports are submitted to the regulators. For implementation of any of the record and/or report conditions summarized in this section, the actual wording of the Permit should be referred to, rather than the summaries.

Table 12-1 is a comprehensive listing of records and reports that could be applicable to the Hanford Facility; the Unit-Specific Portion of this permit application only need list those applicable to a particular TSD unit. The information contained in this chapter need not be duplicated in the Unit-Specific Portion or in preclosure work plan, closure work plan, closure plan, closure/postclosure plan, or postclosure permit application documentation, but could be cross-referenced, as appropriate.

Condition II.I. of the HF RCRA Permit (DW Portion) contains a specific discussion of the contents of the Facility Operating Record, including direction for the inclusion of all other reports, as required by the Permit (Condition II.I. l.t.). The Hanford Facility Operating Record consists of two files, a General Information file and a Unit-Specific file. The 'Records Contacts' for both the General Information and Unit-Specific files can be accessed by calling (509) 373-9327 or (509) 376-2377. Unit-Specific file records are maintained by the individual TSD units and also can be accessed by contacting the TSD unit 'Records Contact'. Unit-Specific file records could be maintained at locations other than the TSD unit. Table 12-1 designates which records and/or reports are contained in the General Information and/or Unit-Specific files. 


\subsubsection{Quarterly Notification of Class 1 Modifications}

Notifications of modifications not otherwise addressed in the HF RCRA Permit (DW Portion) are submitted in accordance with Condition I.C.3. of the Permit, which allows for Class 1 (minor) modifications to be entered into the Hanford Facility Operating Record and submitted to Ecology quarterly (refer to Chapter 2.0, Section 2.1.1.3.3). Any Class 1 modifications made during a quarter are consolidated and submitted in a report within 10 days after the end of that quarter. Quarters end on December 31, March 31 , June 30 , and September 30.

\subsubsection{Monitoring and Records}

Records of monitoring information are to be kept for TSD units in accordance with Condition I.E.10.b. of the HF RCRA Permit (DW Portion). The monitoring information includes calibration and maintenance records and all original strip chart recordings for continuous monitoring instrumentation, copies of reports and records required by the Permit, and records of data used to complete the application for the Permit.

Condition I.E.10.c. of the HF RCRA Permit (DW Portion) pertains to the keeping of records not associated with a particular TSD unit. These records include monitoring and maintenance information, copies of reports and records required by the Permit, and records of data used to complete the application for the Permit.

$$
\begin{aligned}
& \text { Monitoring records also are addressed by Condition II.I.1.n. of the HF RCRA Permit (DW Portion). } \\
& \text { Records specific to groundwater monitoring are discussed in Section 12.1.26. }
\end{aligned}
$$

\subsubsection{Reporting Planned Changes}

In accordance with Condition I.E.11. of the HF RCRA Permit (DW Portion), Ecology is to be notified as soon as possible of any planned physical alterations or additions to the Hanford Facility that have an impact on TSD units or non-TSD unit areas subject to the Permit.

\subsubsection{Certification of Construction or Modifications}

In accordance with Condition I.E.12. of the HF RCRA Permit (DW Portion), notification is to be made that construction or modification of a TSD unit has been accomplished in compliance with the conditions of the Permit. This notification is to be made by a letter signed by the Permittees and a registered professional engineer.

\subsubsection{Anticipated Noncompliance}

In accordance with Condition I.E.13. of the HF RCRA Permit (DW Portion), notification is to be supplied at least 30 days in advance of any planned changes or activities that could result in a noncompliance with the Permit. If the 30-day advance notice is not possible, the Permittees are to supply notice immediately after becoming aware of the anticipated noncompliance. 
1

\subsubsection{Transfer of Permits}

Before transferring ownership or operation of the Hanford Facility during its operating life, the Permittees are to notify the new owner or operator in writing of the requirements of WAC 173-303-600, WAC 173-303-806, and the HF RCRA Permit (DW Portion). This notification is to be conducted in accordance with Condition I.E.14. of the Permit. The Permit may be transferred to a new co-operator in accordance with the provisions of WAC 173-303-830(2).

\subsubsection{Immediate Reporting}

Upon awareness of the circumstances, the Permittees are to immediately report to Ecology any release of dangerous waste or hazardous substances, or any noncompliance with the HF RCRA Permit (DW Portion) that could endanger human health or the environment. This report is to be made in accordance with Condition I.E.15.a. of the Permit.

Upon awareness of the circumstances, the Permittees are to immediately report any information on the release or unpermitted discharge of dangerous waste or hazardous substances that could cause an endangerment to drinking water supplies or ground or surface waters, or of a release or discharge of dangerous waste or hazardous substances, or of a fire or explosion at the Facility that could threaten human health or the environment. This report is to be made in accordance with Condition I.E. 15.c. of the HF RCRA Permit (DW Portion).

\subsubsection{Release or Noncompliance Not Requiring Immediate Reporting}

For any release or noncompliance not required to be reported immediately, a brief account must be entered within 2 days into the Facility Operating Record for TSD units, or into the Facility Operating Record, inspection log or separate spill log, for non-TSD units. This action is to be taken in accordance with Condition I.E.15.d. of the HF RCRA Permit (DW Portion).

\subsubsection{Written Reporting}

Within 15 days of awareness of the circumstances of any noncompliance with the HF RCRA Permit (DW Portion) that could endanger human health or the environment, the Permittees are to provide a written report in accordance with Condition I.E.16. of the Permit.

\subsubsection{Manifest Discrepancy Report}

Condition I.E.17.a. of the HF RCRA Permit (DW Portion) addresses reporting associated with discovery of a significant discrepancy (Appendix 2B) in a manifest for dangerous waste received from outside the Hanford Facility. If not reconciled within 15 days of discovery, the Permittees are to submit a letter report to Ecology in accordance with WAC 173-303-370(4), including a copy of the applicable manifest or shipping paper. 


\subsubsection{Waste Tracking Form Discrepancy Report}

Condition I.E.17.b. of the HF RCRA Permit (DW Portion) addresses reporting associated with discovery of a significant discrepancy (Appendix 2B) in waste tracking forms for dangerous waste transported within the Hanford Facility. If not reconciled within 15 days of discovery, the Permittees are to note the discrepancy in the receiving TSD unit's operating record.

\subsubsection{Other Information}

Condition I.E.20. of the HF RCRA Permit (DW Portion) addresses situations where the Permittees become aware that they have failed to submit any relevant facts in a permit application, closure plan, or postclosure plan, or submitted incorrect information in a permit application, closure plan, or postclosure plan, or in any report to Ecology. In accordance with this condition, the Permittees are to promptly submit such facts or corrected information.

\subsubsection{Permit-Related Documentation}

Records of HF RCRA Permit-related documentation are to be kept and maintained for 10 years after postclosure care or corrective action of the Hanford Site has been certified as complete, whichever is later. The following documents, and amendments, revisions, and modifications to these documents, are to be retained: the HF RCRA Permit and all attachments; all dangerous waste Part B permit applications, postclosure permit applications, and closure plans; and the Facility Operating Record. Retention of this documentation fulfills Condition I.H. of the Permit.

\subsubsection{Notification of Permit-Related Information}

Condition II.E.4. of the HF RCRA Permit (DW Portion) pertains to the provision of a notification of availability to Ecology of data obtained pursuant to the Permit within 30 days of receipt by the Permittees, or after completion of quality assurance/quality control activities, if applicable. If data are obtained routinely, the Permittees only need to provide notification of data availability within 30 days of first availability along with a statement as to expected frequency of future data. If routine data are not acquired at the stated expected frequency, the Permittees are to notify Ecology within 30 days with an explanation and revision, if applicable.

\subsubsection{Waste Location}

Systems to identify and map the locations of SWMUs are documented and maintained within the Hanford Facility Operating Record, in accordance with Condition II.I. 1.a. of the HF RCRA Permit (DW Portion) Applicability Matrix (Attachment 3). These systems include the Hanford Geographic Information System (HGIS) database and the WTDS database. A list identifying active 90-day waste storage areas and dangerous waste satellite accumulation areas and their locations on the Hanford Facility also is maintained by each co-operator. 


\subsubsection{Waste Analysis}

Waste analysis and other waste designation records for each TSD unit are generated in accordance with Condition II.D. (refer to Chapter 3.0, Section 3.2), and maintained in accordance with Condition II.I.1.b. of the HF RCRA Permit (DW Portion). These records include waste analysis and/or other waste designation for waste resulting from an unidentifiable spill or leak, or waste generated at a TSD unit during decontamination or maintenance activities if required.

\subsubsection{Occurrence Reports}

The system to generate occurrence reports is described in operating practices documentation maintained by the Permittees. The Occurrence Notification Center (ONC) is staffed 24 hours a day. This arrangement conforms to the requirements of Condition II.I.1.c. of the HF RCRA Permit (DW Portion).

\subsubsection{Unmanifested Waste Reports}

The Hanford Facility uses waste manifests for tracking offsite waste shipments. The completed waste manifests are the source of two possible reports, the manifest discrepancy report and the unmanifested waste report as cited in Condition I.E.18 of the HF RCRA Permit (DW Portion). Records documenting unmanifested waste shipments are retained by the receiving TSD unit in accordance with Condition II.I.1.d. of the Permit.

\subsubsection{Contingency Plan and Incident Records}

Records documenting the details of any incidents requiring the implementation of the contingency plan are maintained in the Hanford Facility Operating Record, General Information file as required by Conditions II.A and II.I. l.e. of the HF RCRA Permit (DW Portion). The contingency plan incident records are maintained by the Hanford Fire Department as part of the Hanford Facility Operating Record, General Information file. Occurrence reports also are generated to document incidents judged too minor to require the implementation of the contingency plan (e.g., incidents identified as offnormal occurrences, or unusual occurrences).

\subsubsection{Personnel Training Records}

Training records are kept by the individual TSD units, as required by Conditions II.C. and II.I.1.f. of the HF RCRA Permit (DW Portion). Typically, each contractor maintains official training records in a centralized location. These records could be maintained in a hard copy form or by using electronic data storage. At a minimum, training records will consist of course attendance rosters correlating the training received with personnel who were in attendance (refer to Chapter 8.0, Section 8.3). Training records are maintained in accordance with the requirements of the Privacy Act. The training records of personnel are available for inspection purposes through 59 FR 17091, which gives federal, state, and local government officers 'routine use' access to training records where a regulatory program being implemented is applicable to the DOE-RL or contractor program. 


\subsubsection{Preparedness and Prevention Arrangements}

The Hanford Facility Operating Record, General Information file, in accordance with Condition II.B.4. of the HF RCRA Permit (DW Portion), contains Attachment 4 of the HF RCRA Permit (DW Portion); specifically Table 3-1, "Memorandum of Understanding", which details the preparedness and prevention arrangements made with other agencies and governing entities. In accordance with Condition II.I.1.g. of the Permit, these descriptions of arrangements, as amended, are considered a part of the Hanford Facility Operating Record, General Information file.

\subsubsection{Projections of Anticipated Costs for Closure and Postclosure and Postclosure Monitoring and Maintenance}

An annual report of projections of anticipated costs for closure for TSD units included in Parts III and V of the HF RCRA Permit (DW Portion) is made in accordance with Conditions II.H.1, and II.I.1.i. (refer to Chapter 11.0, Section 11.1.8). An annual report of projections of anticipated costs for postclosure monitoring and maintenance for TSD units incorporated into Parts III, V, and VI of the HF RCRA Permit (DW Portion) is made in accordance with Conditions II.H.2. and II.I.1.i. (refer to Chapter 11.0, Section 11.3.5). Annual reports of these cost projections are submitted to Ecology on October 31 of each year, with information updated as of September 30.

\subsubsection{Onsite Transportation Documentation}

Condition II.Q. of the HF RCRA Permit (DW Portion) requires documentation to accompany any onsite dangerous waste that is transported to or from any TSD unit subject to the Permit through or within the 600 Area unless the roadway is closed to general public access at the time of shipment (refer to Chapter 2.0, Sections 2.1.1.1 and 2.4; Figure 2-1). Waste transported by rail or by pipeline is exempt from this condition. To meet the provisions of Condition II.I. 1.j. of the Permit, this documentation is maintained in the receiving TSD unit's Hanford Facility Operating Record, Unit-Specific file.

\subsubsection{Cross-Reference of Waste Location to Waste Manifest Numbers}

In accordance with Condition II.I. I.k. of the HF RCRA Permit (DW Portion), a solid waste information and tracking system contains information concerning containerized waste, including the waste location, quantity, and other manifest data. A description of this system is maintained in the Hanford Facility Operating Record, General Information file.

\subsubsection{Required Annual Reports}

In accordance with Conditions I.E.19. and I.E.22. of the HF RCRA Permit (DW Portion), annual reports are generated and submitted to Ecology. In accordance with Condition II.I. $1 . \mathrm{m}$. of the Permit, annual report information is maintained in the Hanford Facility Operating Record, General Information file. The individual TSD units maintain their respective annual report information within the Unit-Specific file. Reports include the following: 
- Annual noncompliance report

- Annual dangerous waste report

- Annual Hanford Site environmental permitting report

- Annual report on Hanford Site LDR for mixed waste [Condition II.S. (DW Portion); Condition II.G (HSWA Portion)]

- Annual report of projections of anticipated costs for closure and postclosure and postclosure monitoring and maintenance.

The annual report of projections of anticipated costs for closure and postclosure and postclosure monitoring and maintenance is discussed in Section 12.1.22.

The annual noncompliance report is a compilation of all instances of noncompliance not otherwise required to be reported elsewhere, and is submitted at the time the annual dangerous waste report is submitted, in accordance with Condition I.E.19. of the HF RCRA Permit (DW Portion). Currently, the submittal date is March 1 of each year.

Washington State, pursuant to WAC 173-303-390, requires an overall annual report for each facility that holds an active EPA/State identification number. This WAC 173-303 requirement is consistent with provisions of Condition I.E.22. of the HF RCRA Permit (DW Portion), and fulfills the EPA's requirement for a HSWA Biennial Report under 40 CFR 264.75, in accordance with a September 29, 1995, letter received from EPA Region 10 by DOE-RL. The report is due to Ecology on March 1 of each year and is referred to as the 'annual dangerous waste report'. The contents of the Hanford Facility annual dangerous waste report include the following:

- The EPA/State identification number

- Name and address of the Hanford Facility

- Calendar year covered by the report

- Description and quantity of waste managed

- TSD methods

- Waste minimization

- Certification statement signed by an authorized representative.

The Washington State report forms in the "Dangerous Waste Annual Report, Book 1, Forms and Instructions for Treatment, Storage, Disposal, and Recycling Facilities" are completed for this report.

The Annual Hanford Site Environmental Permitting Status Report (DOE/RL-96-63) contains the status of all required environmental permits and notices of construction approvals (refer to Chapter 13.0). This status report is placed in the Hanford Facility Operating Record, General Information file by October 1 of each year.

A discussion of the annual LDR report is contained in Chapter 3.0, Section 3.1.1. 


\subsubsection{Groundwater Monitoring Records}

Groundwater monitoring records, addressed by Condition M.F. of the HF RCRA Permit (DW Portion), are specified for TSD units in Parts II, V, and VI of the Permit. Further discussion of these records is contained in Chapter 5.0, Section 5.2.2.1.

In accordance with Condition II.F.2.a. of the HF RCRA Permit (DW Portion), inspections of active resource protection wells subject to the Permit are to be conducted at least once every 5 years in accordance with WAC 173-160-030. The inspections are to be recorded in the Hanford Facility Operating Record, Unit-Specific file.

In accordance with Condition II.F.2.c. of the HF RCRA Permit (DW Portion), written notice is to be furnished to Ecology at least 72 hours in advance of remediation (excluding maintenance activities) or abandonment of any well subject to the Permit.

As discussed in Sections 12.1.2, other monitoring records could be maintained in the Hanford Facility Operating Record, in accordance with Conditions I.E.10.b. and I.E.10.c. of the Permit.

\subsubsection{Groundwater Corrective Action}

Part IV of the HF RCRA Permit (DW Portion) and Part III of the HF RCRA Permit (HSWA Portion) address corrective action for past-practice units (refer to Chapter 2.0, Sections 2.1.1.3.3 and 2.5). In accordance with Condition II.I.1.p. of the HF RCRA Permit (DW Portion), summaries of all records of groundwater corrective action required by WAC 173-303-645 are included in the Hanford Facility Operating Record, General Information file.

\subsubsection{Permit Condition Compliance Evaluation System}

In accordance with Condition II.I.1.q. of the HF RCRA Permit (DW Portion), an automated database system currently is one of several tools used to track compliance with the Standard and General Facility conditions of the HF RCRA Permit. Each TSD unit incorporated into Parts II, V, or VI of the Permit is responsible for compliance and describing the compliance evaluation system used.

\subsubsection{Deed Notifications}

For those TSD units that cannot be clean closed, a notice in deed must be filed with the county auditor (refer to Chapter 11.0, Section 11.2) in accordance with Condition II.I.1.r. of the HF RCRA Permit (DW Portion). The DOE-RL will certify to Ecology that the information has been duly recorded and will provide Ecology with a copy of the document in which the record was placed.

\subsubsection{Inspection Records}

In accordance with Condition II.O. of the HF RCRA Permit (DW Portion), general facility inspections are conducted according to the provisions in WAC 173-303-320(2) and as described in Chapter 6.0, 
Section 6.2.1. Notification is made to Ecology at least 7 days prior to conducting these inspections. A copy of each annual inspection report is maintained in the Hanford Facility Operating Record, General Information file.

Records of TSD unit-specific inspections, required by Condition II.I.1.s. of the Permit, are maintained for a period of at least 5 years from the inspection date as part of the Hanford Facility Operating Record, Unit-Specific file.

\subsubsection{Descriptions of Systems/Reports}

In accordance with Condition II.I.2. of the HF RCRA Permit (DW Portion), descriptions of systems and/or reports are maintained in the Hanford Facility Operating Record, General Information file. The descriptions required involve the following:

- Condition II.I.1.a. of the Permit (DW Portion): waste location (refer to Section 12.1.15)

\subsubsection{Closure Certification}

Final closure of the Hanford Facility will be achieved when documentation indicates completion of closure activities for all TSD units. Documentation of closure of TSD units is to be accomplished by providing either certifications of closure or certifications of completion of postclosure care, in accordance with Condition II.J.1. of the HF RCRA Permit (DW Portion).

\subsubsection{Notification of, or Request for, a Permit Modification}

Written notification of, or request for, a permit modification is to be submitted whenever there is a change in operating plans, facility design, or the approved closure plan. A copy of the amended closure plan 
1 is to accompany the notification request. This action is to be taken in accordance with Condition II.J.3. of the 2 HF RCRA Permit (DW Portion).

\subsubsection{Closure Plan Deviation}

Deviations from a TSD unit closure plan required by unforseen circumstances encountered during closure activities are to be documented in the Facility Operating Record, Unit-Specific file and made available to Ecology upon request or during the course of an inspection. These deviations are limited to those that do not impact the overall closure strategy but provide equivalent results. Such action is in accordance with Condition II.K.6. of the HF RCRA Permit (DW Portion).

\subsubsection{Engineering Change Notices and Nonconformance Reports}

The ECNs or NCRs that could affect specifically designated critical systems are submitted in accordance with Conditions II.L.2.b. and II.L.2.c. of the HF RCRA Permit (DW Portion) (refer to Chapter 4.0, Sections 4.13.1 and 4.13.4, and to Appendix 2B). All other ECNs or NCRs will be available for inspection.

\subsubsection{As-Built Drawings}

As-built drawings incorporating design and construction modifications for a construction project subject to the HF RCRA Permit (DW Portion) is to be placed into the Facility Operating Record, Unit-Specific File within 12 months of construction completion, or within an alternate approved time period. This action is to be taken in accordance with Condition II.L.2.d. of the Permit.

\subsubsection{Receipt of Wastes Generated Offsite}

Notification of receipt of waste generated outside the United States is to be supplied annually and in writing at least 4 weeks in advance of the first shipment. A copy of this written notice is to be a part of the Facility Operating Record, Unit-Specific file, in accordance with Condition II.N.2. of the HF RCRA Permit (DW Portion).

The Permittees are to notify the generator of offsite-generated waste in writing (except where the owner or operator is also the generator) that they have the appropriate permits for, and will accept, the waste received from offsite sources. A copy of this written notice is to be a part of the Facility Operating Record, Unit-Specific file, in accordance with Condition II.N.3 of the HF RCRA Permit (DW Portion).

\subsubsection{Equivalent Materials}

Condition II.R. of the HF RCRA. Permit (DW Portion) establishes general requirements for the substitution of an equivalent or superior product for any equipment or materials specified in Parts III and V (refer to Chapter 4.0, Section 4.13.3). This condition also requires substitution documentation to be placed in the Hanford Facility Operating Record, Unit-Specific file. 
1

\subsubsection{Land Disposal Restrictions Records}

Condition II.S. (DW Portion) and II.G (HSWA Portion) of the HF RCRA Permit addresses LDR. Onsite waste tracking documents the transfer of waste subject to LDR (refer to Chapter 3.0, Section 3.1.1). Other applicable LDR recordkeeping requirements are identified in WAC 173-303-380 and 40 CFR 268.

\subsubsection{Mapping Methodology Report and Underground Pipline Maps}

In accordance with Condition II.U. of the HF RCRA Permit (DW Portion), and with the mapping methodology report submitted in fulfillment of Condition II.U.1., the methodology report and underground pipeline maps will be located in the Hanford Facility Operating Record, General Information file (refer to Chapter 4.0, Section 4.13.5).

\subsubsection{Other Permit Compliance Documentation}

Condition II.W.1. of the HF RCRA Permit (DW Portion) requires copies of all documents relating to actions taken, pursuant to obtaining all other applicable federal, state, and local permits authorizing the development and operation of the Hanford Facility, to be kept in the Facility Operating Record.

\subsubsection{Schedule Extensions}

Written notification of any deviations or expected deviations from Permit-related schedules is to be supplied to Ecology as soon as possible in accordance with Condition X.1. of the HF RCRA Permit (DW Portion). The notification is to include all supporting information that 'best efforts' have been made to meet the required schedules. Copies of all correspondence regarding schedule extensions is to be kept in the Facility Operating Record.

\subsubsection{Waste Minimization/Pollution Prevention}

In accordance with Conditions II.F. of the HF RCRA Permit (HSWA Portion), onsite generating units complete a waste minimization/pollution prevention certification annually certifying that a waste minimization/pollution prevention program is in place (refer to Chapter 10.0). A copy of the certification is maintained in the Hanford Facility Operating Record, Unit-Specific file.

\subsection{TYPE OF SUBMITTAL}

Table 12-1 denotes the protocol for submitting reports. Three options exist: immediate verbal reporting; information submitted via transmittal letters signed by Permittee representatives; and packages certified by the Permittees in accordance with WAC 173-303-810(12) and (13) and/or by a registered professional engineer [e.g., in accordance with WAC 173-303-810(14)(a)(i) (refer to Chapter 4.0, Section 4.13.4)]. The protocol for submitting reports also is based on a teleconference held with Ecology on March 3, 1995. 
This page intentionally left blank. 


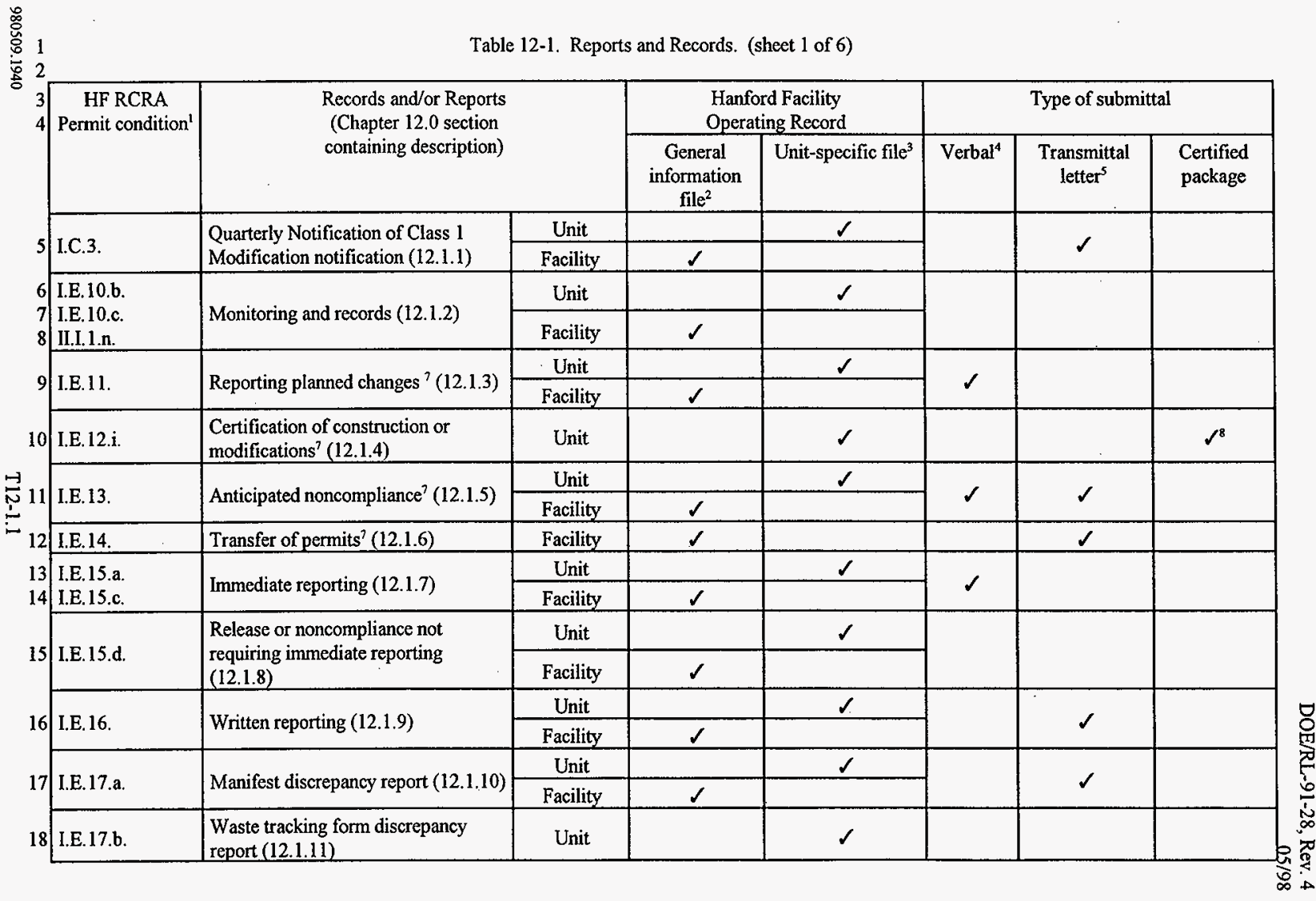




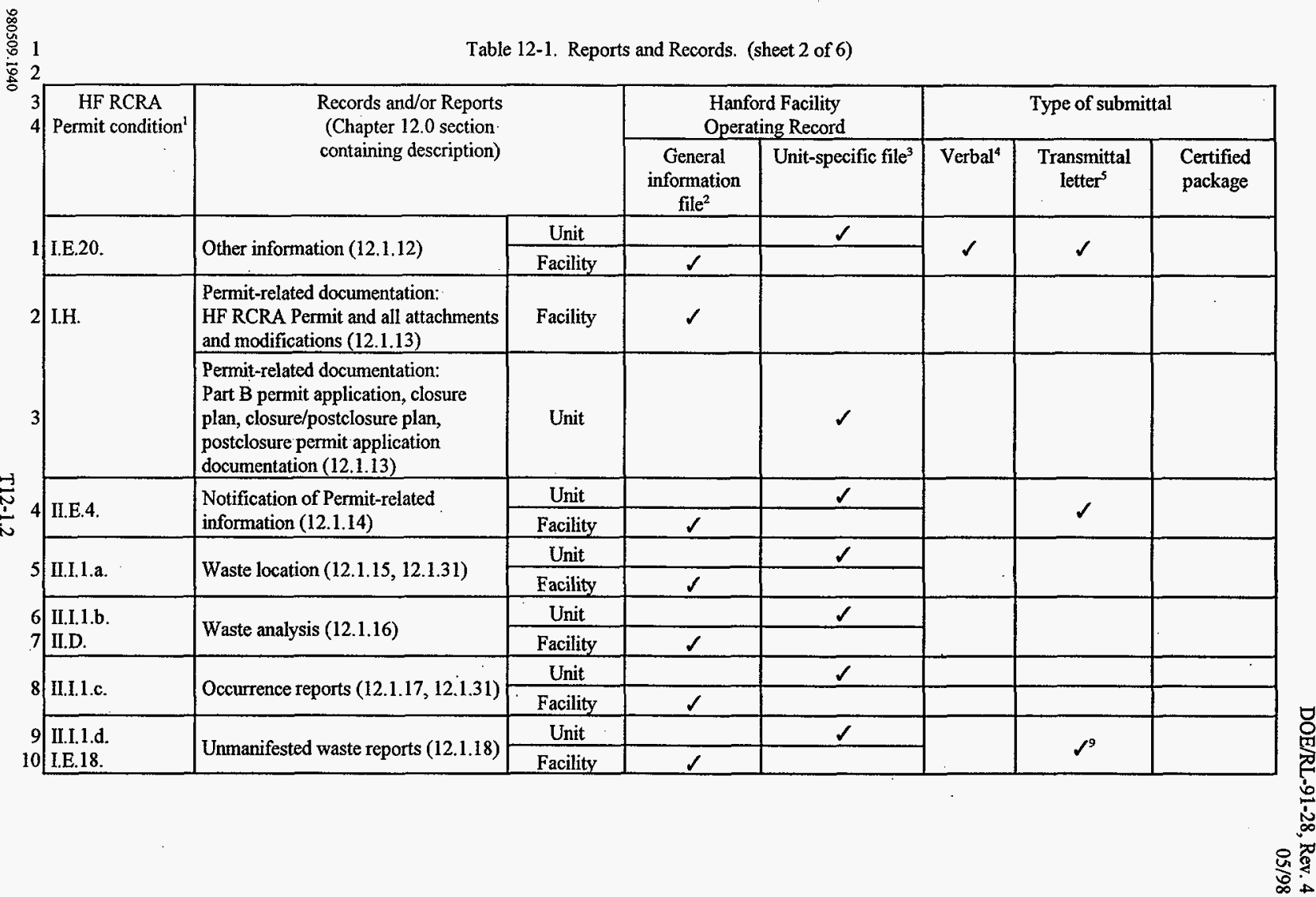


Table 12-1. Reports and Records. (sheet 3 of 6 )

逭 2

\begin{tabular}{|c|c|c|c|c|c|c|c|c|}
\hline \multirow[t]{2}{*}{$\begin{array}{l}3 \\
4\end{array}$} & \multirow[t]{2}{*}{$\begin{array}{l}\text { HF RCRA } \\
\text { Permit condition' }\end{array}$} & \multirow{2}{*}{\multicolumn{2}{|c|}{$\begin{array}{l}\text { Records and/or Reports } \\
\text { (Chapter } 12.0 \text { section } \\
\text { containing description) }\end{array}$}} & \multicolumn{2}{|c|}{$\begin{array}{l}\text { Hanford Facility } \\
\text { Operating Record }\end{array}$} & \multicolumn{3}{|c|}{ Type of submittal } \\
\hline & & & & General & Unit-specific file ${ }^{3}$ & Verbal $^{4}$ & Transmittal & Certified \\
\hline \multirow{2}{*}{$\begin{array}{l}1 \\
2\end{array}$} & \multirow{2}{*}{$\begin{array}{l}\text { II.I.1.e. } \\
\text { II.A. (all) }\end{array}$} & \multirow{2}{*}{$\begin{array}{l}\text { Hanford Emergency Response Plan } \\
\text { and incident records (12.1.19) }\end{array}$} & Unit & & $\checkmark$ & \multirow[b]{2}{*}{$\checkmark$} & \multirow[b]{2}{*}{$\checkmark$} & \multirow{2}{*}{ (II.A. I. only) } \\
\hline & & & Facility & $\checkmark$ & & & & \\
\hline \multirow{2}{*}{3 . } & \multirow{2}{*}{$\begin{array}{l}\text { II.I.1.f. } \\
\text { II.C. }\end{array}$} & \multirow{2}{*}{$\begin{array}{l}\text { Personnel training records }(12.1 .20 \text {, } \\
\text { 12.1.31) }\end{array}$} & Unit & & $\checkmark$ & & & \\
\hline & & & Facility & $\checkmark$ & & & & \\
\hline 6 & $\begin{array}{l}\text { Il.I.1.g. } \\
\text { II.B.4. }\end{array}$ & $\begin{array}{l}\text { Preparedness and prevention } \\
\text { arrangements (12.1.21) }\end{array}$ & Facility & $\checkmark$ & & & & \\
\hline \multirow{2}{*}{$\begin{array}{l}7 \\
8\end{array}$} & \multirow{2}{*}{$\begin{array}{l}\text { II.I.1.i. } \\
\text { II.H. }\end{array}$} & \multirow{2}{*}{$\begin{array}{l}\text { Projections of anticipated costs for } \\
\text { closure and postclosure and } \\
\text { postclosure monitoring and } \\
\text { maintenance }(12.1 .22,12.1 .25 \text {, and } \\
12.1 .31)\end{array}$} & Unit & & $\checkmark$ & & \multirow{2}{*}{$\checkmark$} & \\
\hline & & & Facility & $\checkmark$ & & & & \\
\hline 9 & II.I.1.j. & $\begin{array}{l}\text { Onsite transportation documentation } \\
\text { (12.1.23) }\end{array}$ & Unit & & $\checkmark$ & & & \\
\hline \multirow{2}{*}{10} & \multirow{2}{*}{ II.I.1.k. } & \multirow{2}{*}{$\begin{array}{l}\text { Cross-reference of waste location to } \\
\text { waste manifest numbers (12.1.24, } \\
\text { 12.1.31) }\end{array}$} & Unit & & $\checkmark$ & & & \\
\hline & & & Facility & $\checkmark$ & & & & \\
\hline
\end{tabular}




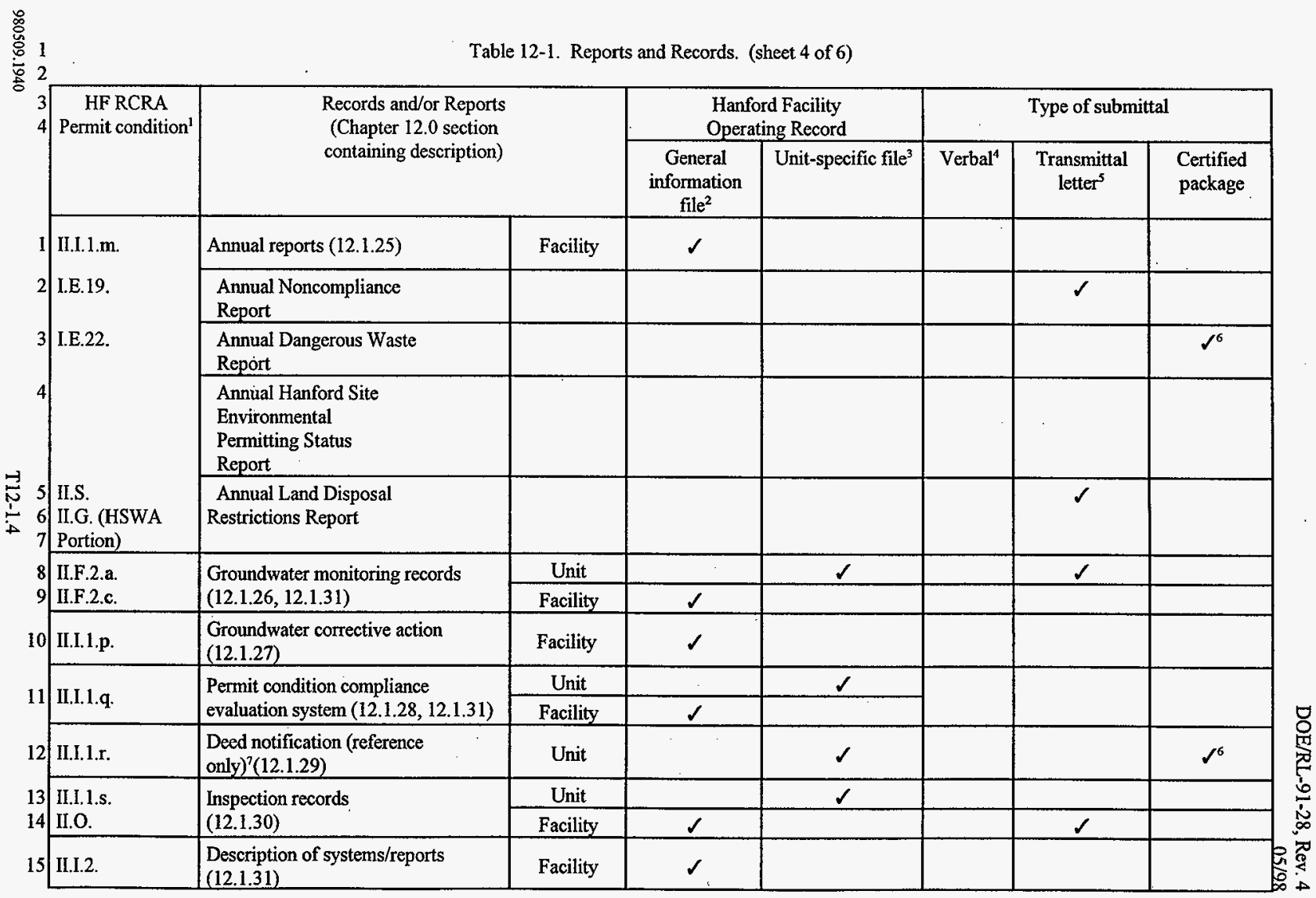


Table 12-1. Reports and Records. (sheet 5 of 6 )

용

\begin{tabular}{|c|c|c|c|c|c|c|c|}
\hline \multirow[t]{2}{*}{$\begin{array}{c}\text { HF RCRA } \\
\text { Permit condition }\end{array}$} & \multirow{2}{*}{\multicolumn{2}{|c|}{$\begin{array}{l}\text { Records and/or Reports } \\
\text { (Chapter } 12.0 \text { section } \\
\text { containing description) }\end{array}$}} & \multicolumn{2}{|c|}{$\begin{array}{l}\text { Hanford Facility } \\
\text { Operating Record }\end{array}$} & \multicolumn{3}{|c|}{ Type of submittal } \\
\hline & & & General & Unit-specific file ${ }^{3}$ & Verbal $^{4}$ & Transmittal & Certified \\
\hline II.J.1. & Closure certification 7 (12.1.32) & Unit & & $\checkmark$ & & & $\checkmark^{10}$ \\
\hline \multirow{2}{*}{ II.J.3. } & \multirow{2}{*}{$\begin{array}{l}\text { Notification of, or request for, a } \\
\text { permit modification' (12.1.33) }\end{array}$} & Unit & & $\checkmark$ & & \multirow{2}{*}{$\checkmark$} & \multirow{2}{*}{$\gamma^{6}$} \\
\hline & & Facility & $\checkmark$ & & & & \\
\hline II.K.6. & Closure plan deviation ${ }^{\top}(12.1 .34)$ & Unit & & $\checkmark$ & & & \\
\hline $\begin{array}{l}\text { II.I. 1.t. } \\
\text { II.L.2.b. } \\
\text { II.L.2.c. } \\
\end{array}$ & $\begin{array}{l}\text { Engineering change notices and } \\
\text { nonconformance reports (12.1.35) }\end{array}$ & Unit & & $\checkmark$ & & & $\mathfrak{S}^{8}$ \\
\hline II.L.2.d. & As-built drawings ${ }^{7}(12.1 .36)$ & Unit & & $\checkmark$ & & & \\
\hline \begin{tabular}{|l|} 
II.N.2. \\
II.N.3. \\
\end{tabular} & $\begin{array}{l}\text { Receipt of wastes generated offsite } \\
\text { (12.1.37) }\end{array}$ & Unit & & $\checkmark$ & & $\checkmark$ & \\
\hline II.R. & Equivalent materials ${ }^{7}(12.1 .38)$ & Unit & & $\checkmark$ & & & \\
\hline $\begin{array}{l}\text { II.S. } \\
\text { II.G (HSWA } \\
\text { Portion) } \\
\end{array}$ & $\begin{array}{l}\text { Land disposal restrictions records } \\
(12.1 .39)\end{array}$ & Unit & & $\checkmark$ & & $\checkmark$ & \\
\hline II.U. & $\begin{array}{l}\text { Mapping methodology report and } \\
\text { underground pipeline maps }(12.1 .40)\end{array}$ & Facility & $\checkmark$ & & & $\checkmark$ & \\
\hline \multirow{2}{*}{ II.W.1. } & \multirow{2}{*}{$\begin{array}{l}\text { Other permit compliance } \\
\text { documentation }^{7}(12.1 .41)\end{array}$} & Unit & & $\checkmark$ & & & \\
\hline & & Facility & $\checkmark$ & & & & \\
\hline \multirow{2}{*}{ II.X.1. } & \multirow{2}{*}{ Schedule extensions ${ }^{7}(12.1 .42)$} & Unit & & $\checkmark$ & & \multirow{2}{*}{$\checkmark$} & \\
\hline & & Facility & $\checkmark$ & & & & \\
\hline
\end{tabular}


Table 12-1. Reports and Records. (sheet 6 of 6 )

\begin{tabular}{|c|c|c|c|c|c|c|c|}
\hline \multirow[t]{2}{*}{$\begin{array}{c}\text { HF RCRA } \\
\text { Permit condition' }\end{array}$} & \multirow{2}{*}{\multicolumn{2}{|c|}{$\begin{array}{l}\text { Records and/or Reports } \\
\text { (Chapter } 12.0 \text { section } \\
\text { containing description) }\end{array}$}} & \multicolumn{2}{|c|}{$\begin{array}{l}\text { Hanford Facility } \\
\text { Operating Record }\end{array}$} & \multicolumn{3}{|c|}{ Type of submittal } \\
\hline & & & $\begin{array}{c}\text { General } \\
\text { information } \\
\text { file }^{2}\end{array}$ & Unit-specific file $^{3}$ & Verbal $^{4}$ & $\begin{array}{c}\text { Transmittal } \\
\text { letter }^{5}\end{array}$ & $\begin{array}{l}\text { Certified } \\
\text { package }\end{array}$ \\
\hline $\begin{array}{l}\text { II.F (HSWA } \\
\text { Portion) }\end{array}$ & $\begin{array}{l}\text { Waste minimization/pollution } \\
\text { prevention (12.1.43) }\end{array}$ & Unit & & $\checkmark$ & & & \\
\hline
\end{tabular}

${ }^{1}$ HF RCRA Permit (DW Portion) Condition, unless otherwise noted.

${ }^{2}$ Hanford Facility Operating Record, General Information file.

${ }^{3}$ Hanford Facility Operating Record, Unit-Specific file.

${ }^{4}$ Verbal reporting in accordance with timeframes noted in the specified conditions.

${ }^{5}$ Not certified; submittal by transmittal letter.

${ }^{6}$ Certified by Permittees in accordance with WAC 173-303-810(12).

${ }^{7}$ Miscellaneous support records and reports.

${ }^{8}$ Certified by a registered professional engineer [e.g., in accordance with WAC 173-303-810(14)(a)(i) (refer to Chapter 4.0, Section 4.13.4)].

- Specific language preprinted on Washington State Department of Ecology's TSD Facility Unmanifested Dangerous Waste Report, Form 6, provides certification in accordance with WAC 173-303-390(1) and WAC 173-303-390(1)(f).

${ }^{10}$ Certified by a registered professional engineer [e.g., in accordance with WAC 173-303-610(6) or WAC 173-303-610(11). 


\section{CONTENTS}

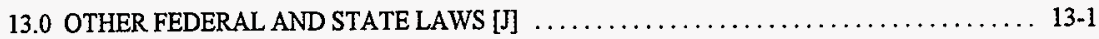

13.1 ENVIRONMENTAL PERMITS AND APPROVALS $\ldots \ldots \ldots \ldots \ldots \ldots \ldots \ldots \ldots \ldots \ldots$

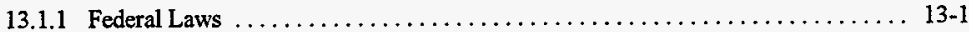

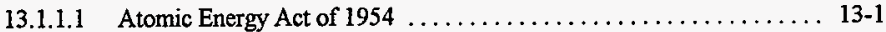

13.1.1.2 Federal Facility Compliance Act of $1992 \ldots \ldots \ldots \ldots \ldots \ldots \ldots \ldots$. 13-2

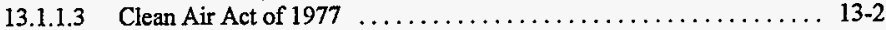

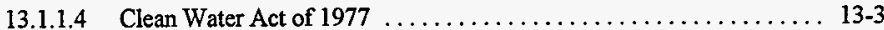

13.1.1.5 Safe Drinking Water Act of $1974 \ldots \ldots \ldots \ldots \ldots \ldots \ldots \ldots \ldots \ldots$ 13-3

13.1.1.6 Comprehensive Environmental Response, Compensation, and

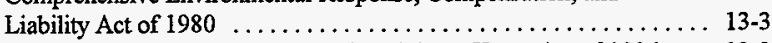

13.1.1.7 Emergency Planning and Community Right-to-Know Act of $1986 \quad \ldots \quad$ 13.3

13.1.1.8 Toxic Substances Control Act of $1976 \ldots \ldots \ldots \ldots \ldots \ldots \ldots \ldots$. 13-3

13.1.1.9 Wild and Scenic Rivers Act of $1968 \ldots \ldots \ldots \ldots \ldots \ldots \ldots \ldots \ldots .13-4$

13.1.1.10 Hanford Reach Study Act of $1988 \ldots \ldots \ldots \ldots \ldots \ldots \ldots \ldots \ldots \ldots . \ldots \ldots$

13.1.1.11 Rivers and Harbors Act of $1899 \ldots \ldots \ldots \ldots \ldots \ldots \ldots \ldots \ldots .13-4$

13.1.1.12 National Historic Preservation Act of $1966 \ldots \ldots \ldots \ldots \ldots \ldots \ldots$. 13-4

13.1.1.13 Endangered Species Act of $1973 \ldots \ldots \ldots \ldots \ldots \ldots \ldots \ldots \ldots .13-4$

13.1.1.14 Fish and Wildlife Coordination Act of $1934 \ldots \ldots \ldots \ldots \ldots \ldots$. 13-4

13.1.1.15 Federal Insecticide, Fungicide, and Rodenticide Act of 1975 ...... 13-5

13.1.1.16 Hazardous Materials Transportation Act of 1975 ............. 13.5

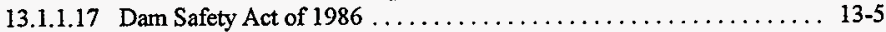

13.1.1.18 National Environmental Policy Act of $1969 \ldots \ldots \ldots \ldots \ldots \ldots .13-5$

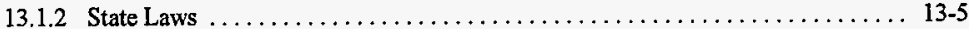

13.1.2.1 Washington Clean Air Act of $1967 \ldots \ldots \ldots \ldots \ldots \ldots \ldots \ldots$ 13-5

13.1.2.2 Washington Water Pollution Control Act of $1945 \ldots \ldots \ldots \ldots \ldots$. 13-6

13.1.2.3 Solid Waste Management Act of 1969 .................. 13-6

13.1.2.4 Washington Pesticide Control Act of $1971 \ldots \ldots \ldots \ldots \ldots \ldots$. 13-6

13.1.2.5 Washington Underground Storage Tank Law of 1989 .......... 13-6

13.1.2.6 Aquatic Lands Leases ............................. 13-6

13.1.2.7 Hydraulic Projects Permits .......................... 13-6

13.1.2.8 New Source Construction Permits $\ldots \ldots \ldots \ldots \ldots \ldots \ldots \ldots \ldots$ 13-7

13.1.2.9 Septic System Approvals/Permits $\ldots \ldots \ldots \ldots \ldots \ldots \ldots \ldots \ldots$ 13-7

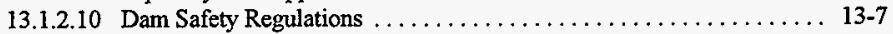

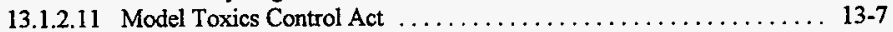

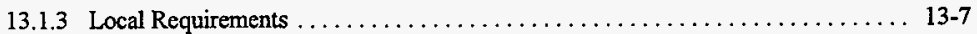

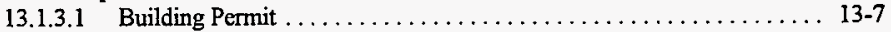

13.1.3.2 Grading Permit $\ldots \ldots \ldots \ldots \ldots \ldots \ldots \ldots \ldots \ldots \ldots \ldots \ldots \ldots \ldots \ldots \ldots \ldots, 13-7$

13.1.3.3 Waste Water Pretreatment Discharge Authorization ............ 13-7

13.1.3.4 Washington Shoreline Management Act of 1971 ............ 13-8

13.1.3.5 Benton Clean Air Authority Regulation $1 \ldots \ldots \ldots \ldots \ldots \ldots$ 13-8

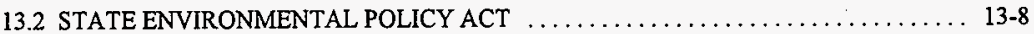


4 13-1. Summary of Other Federal and State Laws and Local Requirements That Could Be 


\subsection{OTHER FEDERAL AND STATE LAWS [J]}

This chapter discusses environmental permits and approvals required for the Hanford Facility as specified by other federal and state laws and local requirements. This chapter addresses the provisions of Section J of Ecology's permit application guidance (Ecology 1987 and 1996). Much of the information requested in Section J is included in the Annual Hanford Site Environmental Permitting Status Report (Annual Status Report) (DOE/RL-96-63), issued on October 1. This report contains a listing and status of all required environmental permits and approvals and construction approvals. A copy of the current Annual Status Report will be maintained in the Hanford Facility Operating Record, General Information file (refer to Chapter 12.0, Section 12.1.25).

The information contained in, and/or referenced in, this chapter also addresses the State Environmental Policy Act (SEPA) of 1971 and Condition II.W. (Other Permits and/or Approvals) of the HF RCRA Permit (DW Portion). Condition II.W of the Permit specifies that the Permittees will be responsible for obtaining all other applicable federal, state, and local permits authorizing the development and operation of the Hanford Facility. Condition IL.W. of the Permit further specifies that the Permittees are to use their best efforts to obtain such permits. For the purposes of this permit application, 'best efforts' mean submittal of documentation and/or approval(s) in accordance with schedules specified in applicable regulations, or as determined through negotiations with the applicable regulatory agencies.

The remainder of this chapter contains a brief description of federal and state laws and local requirements that could be applicable to the Hanford Facility; the Unit-Specific Portion of this permit application only need list those applicable to a particular TSD unit. The information contained in this chapter need not be duplicated in the Unit-Specific Portion or in preclosure work plan, closure work plan, closure plan, closure/postclosure plan, or postclosure permit application documentation, but can be cross-referenced, as appropriate.

\subsection{ENVIRONMENTAL PERMITS AND APPROVALS}

This section contains a brief description of the federal and state laws and local requirements that could be applicable to the Hanford Facility. The appropriate regulatory agency(s) administering these laws and requirements also is noted. Permits and approvals prepared in response to these laws and requirements are identified in the Annual Status Report.

\subsubsection{Federal Laws}

This section contains a brief description of federal laws that could be applicable to the Hanford Facility.

13.1.1.1 Atomic Energy Act of 1954. The Atomic Energy Act provides that the U.S. Atomic Energy Commission (succeeded by the U.S. Department of Energy for conducting nuclear defense, waste management, environmental restoration and remediation, and RD\&D activities on the Hanford Site) is authorized to develop and implement regulations to govern activities related to the design, location, and operation of U.S. Department of Energy sites, to protect health, and to minimize danger to life or property. The radioactive component of mixed waste is interpreted by the U.S. Department of Energy to be regulated 
1 under the Atomic Energy Act; the nonradioactive dangerous component of mixed waste is interpreted to be 2 regulated under the RCRA and WAC 173-303 (refer to Chapter 2.0, Section 2.1.1.3.1).

The U.S. Department of Energy has adopted regulations to govern the activities of its sites and to manage the health protection aspects of mixed waste. These regulations provide for a consistent approach to managing radioactive materials that result from U.S. Department of Energy activities. The regulations set radiation exposure limits and concentration guidelines to minimize exposure to radiation. All Hanford Facility operations are conducted in accordance with these regulations.

13.1.1.2 Federal Facility Compliance Act of 1992. The Federal Facility Compliance Act provides for the express waiver of immunity otherwise applicable to the United States with respect to substantive and procedural requirements of the RCRA.

13.1.1.3 Clean Air Act of 1977. The Clean Air Act establishes a federal and state cooperative scheme to control the airborne emissions of pollutants to enhance air quality and prevent further deterioration. This control is accomplished by achieving and setting standards for abating air pollution, and by maintaining the federally-mandated National Ambient Air Quality Standards (42 USC 7401 et seq.). Air standards are implemented and enforced primarily by state and local air quality authorities. Amendments to the Clean Air Act in 1990 significantly expanded the scope of regulation particularly in the area of hazardous air pollutants. These amendments require EPA to promulgate dozens of regulations under state authority to meet the schedule of the federal amendments. The State of Washington Clean Air Act regulations (refer to Section 13.1.2.1) address control of nearly 700 air pollutants, including air toxins, hazardous air pollutants (including radioactive airborne emissions), ozone-depleting substances, and pollutants suspected of causing global warming. Compliance with these regulations requires specific actions before construction, startup, and normal operations of facilities (e.g., notices of construction, source registration, annual reporting, air operating permit applications, etc.). The regulations require prior approval by one or more air quality authority(ies) before any construction or modification can begin that could supply any significant increase in air emissions.

The Hanford Site is located within an airshed that meets all federal and state ambient air quality standards, and thus has been declared an "attainment area". Therefore, for the Hanford Site, the Prevention of Significant Deterioration Clean Air Act requirements apply to emissions of pollutants traditionally released from fossil fueled power plants or other large industrial sources; i.e., pollutants such as carbon monoxide, nitrogen oxides, sulfur oxides, particulate matter, ozone, lead, asbestos, mercury, etc., commonly referred to as the "criteria pollutants" (Appendix 2B). The Prevention of Significant Deterioration regulations are intended to protect the regional air quality while allowing a margin for future industrial growth. As such, the regulations require prior construction approval, and best available control technology for any large new source of air emissions or any source modifications involving significant increases in criteria pollutant emissions. The Hanford Site is considered a major Prevention of Significant Deterioration source because of pollutant emissions from various coal and oil fired steam generating plants onsite (i.e., nitrogen oxides). In addition, air toxics are regulated under the National Emission Standards for Hazardous Air Pollutants. This program applies without regard to attainment status. Applicable federal requirements to control and abate air pollution include the following:

- New Source Performance Standards (40 CFR 60)

- National Emission Standards for Hazardous Air Pollutants (40 CFR 61) 
- National Emission Standard for Radionuclide Emissions from U.S. Department of Energy Facilities (40 CFR 61, Subpart H).

13.1.1.4 Clean Water Act of 1977. The Clean Water Act establishes national ambient water quality standards and sets standards for abating water pollution and preventing further deterioration of the water quality. This Act also provides for the protection of wet lands. The Clean Water Act requires permits for discharges of liquid effluents to surface waters and for dredge and fill activities in "waters of the United States". These standards are implemented and enforced primarily by state and local authorities (refer to Section 13.1.2.2). However, the EPA has authority for National Pollution Discharge Elimination System (NPDES) permitting at federal facilities. Potentially applicable or relevant regulations relating to water pollution and water quality include the following:

- U.S. Army Corps of Engineers Permit Regulations for Structures (33 CFR 322)

- U.S. Army Corps of Engineers National Permit Program Regulations (33 CFR 330)

- National Pollutant Discharge Elimination System (40 CFR 121 to 125).

Portions of the Clean Water Act regulations are administered on the Hanford Site by the EPA, the U.S. Coast Guard, or the U.S. Army Corps of Engineers.

13.1.1.5 Safe Drinking Water Act of 1974. The Safe Drinking Water Act provides for protection of human health by setting standards for water supplied for public consumption and by protecting public drinking water sources. This Act sets drinking water standards, protects groundwater, and regulates underground injection wells. Drinking water systems at the Hanford Facility are in compliance with these standards. Safe Drinking Water Act regulations are administered by the Washington State Department of Health and Ecology (refer to Section 13.1.2.2).

13.1.1.6 Comprehensive Environmental Response, Compensation, and Liability Act of 1980. The CERCLA, as amended in 1986 by the Superfund Amendments and Reauthorization Act, establishes a process for undertaking remedial action at inactive waste sites that contain hazardous substances, and establishes reporting requirements for releases of hazardous substances. The CERCLA remedial process has been initiated on the Hanford Site in response to identification on the National Priorities List. The Tri-Party Agreement addresses how RCRA corrective actions and CERCLA remedial actions are to be integrated on the Hanford Facility. The CERCLA regulations are administered by the EPA.

13.1.1.7 Emergency Planning and Community Right-to-Know Act of 1986. The Emergency Planning and Community Right-to-Know Act is a freestanding provision of the Superfund Amendments and Reauthorization Act. This Act establishes the framework for state and local emergency planning and provides a mechanism for community awareness of hazardous chemicals present in a locality. Release notification, community right-to-know reporting, and toxic chemical release and inventory reporting are made in response to this Act. The Emergency Planning and Community Right-to-Know Act regulations are administered by the EPA.

13.1.1.8 Toxic Substances Control Act of 1976. The Toxic Substances Control Act provides for protection of human health and the environment from exposure to certain hazardous and toxic chemical substances and mixtures (e.g., PCBs and newly manufactured chemicals). The Hanford Facility has in place a program for the cleanup, treatment, and disposal of materials regulated by the Toxic Substances Control Act. The regulations derived from the act are administered by the EPA. 
13.1.1.9 Wild and Scenic Rivers Act of 1968. The Hanford Facility does not affect any rivers presently designated under the Wild and Scenic Rivers Act. However, this act could apply, depending on the outcome of a study conducted in response to Public Law 100-605 (refer to Section 13.1.1.10).

\begin{abstract}
13.1.1.10 Hanford Reach Study Act of 1988. The Hanford Reach Study Act (Public Law 100-605), directs the Secretary of the Interior to prepare a study on the Hanford Reach of the Columbia River to consider the addition of the Hanford Reach to the National Wild and Scenic Rivers System. During the 8-year study period ending in 1996, activities undertaken from river miles 396 to 345 and within a quarter-mile of the Columbia River mean high-level mark must be conducted in consultation and coordination with the U.S. Department of Interior-National Park Service, acting for the Secretary of the Interior. Public Law 104-333 extended the requirements in the Act indefinitely. Hanford Site activities undertaken within the Hanford Reach are conducted in compliance with the Hanford Reach Study Act.
\end{abstract}

13.1.1.11 Rivers and Harbors Act of 1899. The Rivers and Harbors Act, sometimes referred to as the Refuse Act, is an 1899 statute that was designed to protect navigation, and had provisions to permit the discharge of refuse into the navigable waters of the United States. The refuse portion of the act was superseded in 1972 by the Federal Water Pollution Control Act, which has become known as the Clean Water Act. The U.S. Army Corps of Engineers administers the portion of the Rivers and Harbors Act related to construction of obstructions in U.S. navigable waters and requires permits before construction of such obstructions.

\title{
13.1.1.12 National Historic Preservation Act of 1966. The National Historic Preservation Act
} establishes national policy to preserve historic places, which include sites, structures, and objects significant in American history, archeology, or culture. The Hanford Facility has in place requirements for the preservation of historical sites and cultural resources. During any future construction activity for a TSD unit, the site will be monitored for the presence of archaeological resources in accordance with regulations issued pursuant to, or other requirements of, the American Antiquities Preservation Act of 1906; the Historic Sites, Buildings and Antiquities Act of 1935; the Archaeological and Historic Preservation Act of 1960; the Archeological Resources Protection Act of 1979; and the American Indian Religious Freedom Act of 1978. Regulations derived from these acts are administered by the U.S. Department of Interior's Advisory Council on Historic Preservation and the Fish and Wildlife Services.

\subsubsection{Endangered Species Act of 1973. The Endangered Species Act establishes a program for} conserving endangered species and their ecosystems. Most activities on the Hanford Facility take place in areas that have been extensively developed during past construction. It is not expected that any listed or proposed endangered or threatened species or their habitats will be affected by Hanford Facility TSD unit activities. However, activities outside extensively developed areas will be reviewed for applicability and compliance. In the event that such species or habitats must be disturbed as a part of Hanford Facility operating or restoration and remediation activities, mitigative measures will be taken in accordance with applicable requirements. The Endangered Species Act regulations are administered by the U.S. Department of Interior-Fish and Wildlife Service.

\subsubsection{Fish and Wildlife Coordination Act of 1934. The Fish and Wildlife Coordination Act} authorizes the U.S. Secretary of the Interior to assist and cooperate with public and private organizations to protect fish and wildlife. Activities at the Hanford Facility impacted by the Fish and Wildlife Coordination Act, such as the building or demolition of an outfall, will be handled in accordance with an agreement between the U.S. Department of Energy and the Washington State Department of Fisheries. Other Acts with regulations relevant to wildlife that could impact activities on the Hanford Facility include the Migratory 
Bird and Treaty Act of 1918 and the Bald and Golden Eagle Protection Act of 1940 . Regulations derived from both Acts are administered by the U.S. Department of Interior-Fish and Wildlife Service.

13.1.1.15 Federal Insecticide, Fungicide, and Rodenticide Act of 1975. The Federal Insecticide, Fungicide, and Rodenticide Act establishes a program to regulate the manufacture, sale, and use of pesticides and disposal of pesticides and containers. The use of all pesticides on the Hanford Facility is done in compliance with the Federal Insecticide, Fungicide, and Rodenticide Act. Regulations derived from this Act are administered by the EPA.

13.1.1.16 Hazardous Materials Transportation Act of 1975. The Hazardous Materials Transportation Act regulates the transport of hazardous materials and hazardous waste to and from the Hanford Site. Regulations promulgated pursuant to this Act are administered by the U.S. Department of Transportation and are set forth in 49 CFR Parts 100 to 177.

13.1.1.17 Dam Safety Act of 1986. The Dam Safety Act applies to the inspection of dams to ensure the integrity of structures. Dam safety at the Hanford Site is administered in accordance with the Washington State dam safety regulations (refer to Section 13.1.2.11).

13.1.1.18 National Environmental Policy Act of 1969. The National Environmental Policy Act (NEPA) establishes a broad national policy for protection of environmental quality and provides the means for implementing that policy early on in the decision-making process. Activities at the Hanford Site are subject to review for compliance with NEPA requirements. The U.S. Department of Energy is responsible for implementing NEPA requirements pursuant to its regulations (10 CFR 1021), which are based on the Council of Environmental Quality regulations ( $40 \mathrm{CFR} 1500$ ). For cleanup and closure activities, the requirements of NEPA (including cumulative impacts and environmental justice) will be integrated with the CERCLA response action and RCRA corrective action processes.

\subsubsection{State Laws}

This section contains a brief description of state laws that could be applicable to the Hanford Facility. Where appropriate, these descriptions cross-reference information presented in the previous section on federal laws. Permits and approvals prepared in response to these laws are identified in the Annual Status Report.

13.1.2.1 Washington Clean Air Act of 1967. The Washington Clean Air Act implements, at the state level, provisions of the federal Clean Air Act (refer to Section 13.1.1.3). Under the authority of this Act, Ecology establishes standards and rules in WAC 173-400 that generally are applicable to the control and/or prevention of air pollution from air contaminant sources. Under the provisions of Chapter $70.98 \mathrm{RCW}$, the Washington State Department of Health has sole responsibility for implementing the radiation protection provisions of the WAC 246-247. The Washington State Department of Health regulates sources that emit radionuclides to the air. In addition, the Washington State Department of Health and Ecology have established a memorandum of understanding that defines the roles and responsibilities of each department regarding administration of radiation control in the Washington State and on the Hanford Site in particular. Regulations relating to the Washington Clean Air Act include the following:

- General Regulations for Air Pollution Sources (WAC 173-400)

- Open Burning (WAC 173-425) 
- Air Operating Permit Regulation (WAC 173-401)

- Controls for New Sources of Toxic Air Pollutants (WAC 173-460)

- Ambient Air Quality Standards and Emission Limits for Radionuclides (WAC 173-480)

- Emission Standards and Controls for Sources Emitting Gasoline Vapors (WAC 173-491)

- Radiation Protection - Air Emissions (WAC 246-247).

\subsubsection{Washington Water Pollution Control Act of 1945. The Washington Water Pollution Control} $A c t$ applies to surface and groundwaters of the State and implements, at the state level, provisions of the federal Clean Water Act (refer to Section 13.1.1.4). This Act requires the development of State Waste Discharge Permits and Onsite Sewage Disposal System Approvals and is administered by Ecology and the Washington State Department of Health. Regulations relating to water pollution and water quality include the following:

- Washington State Waste Discharge Permitting Program (WAC 173-216)

- Underground Injection Control Program (WAC 173-218)

- Water Quality Standards for Ground Waters of the State of Washington (WAC 173-200)

- Water Quality Standards for Surface Waters of the State of Washington (WAC 173-201)

- On-Site Sewage System (WAC 246-272).

13.1.2.3 Solid Waste Management Act of 1969. The Solid Waste Management Act serves to protect public health, to prevent land, air, and water pollution, and to conserve the state's natural, economic, and energy resources through the requirements set forth in WAC 173-304. The regulations in WAC 173-304 established the minimum standards that municipalities, regional agencies, state, and local governments must follow to provide a state-wide consistency and expectation as to the level at which solid waste must be managed. The Solid Waste Management Act provisions are administered by Ecology.

\subsubsection{Washington Pesticide Control Act of 1971. The Washington Pesticide Control Act requires} registration of pesticide applicators. This Act implements, at the state level, the Federal Insecticide, Fungicide, and Rodenticide Act (refer to Section 13.1.1.15). Regulations derived from this act are administered by the Washington State Department of Agriculture.

13.1.2.5 Washington Underground Storage Tank Law of 1989. The Washington Underground Storage Tank Law and the Washington Underground Petroleum Storage Tank Law regulate underground storage tanks, and set performance standards, operational and maintenance requirements, and tank closure requirements. The provisions of this law are administered by Ecology in accordance with the requirements set forth in WAC 173-360. This law implements, at the state level, Subchapter IX of RCRA, 42 USC $\$ 6991$ et seq.

13.1.2.6 Aquatic Lands Leases. Aquatic land activities that interfere with the general public's use of state-owned tidelands, shorelands, and beds of navigable waters, require authorization before construction from the Washington State Department of Natural Resources by way of agreement, lease, permit, or other instrument(s).

13.1.2.7 Hydraulic Projects Permits. Any construction or other work that will change the natural flow of a river, including the addition of treated effluent waste water that will increase the natural flow, is required to obtain a hydraulic project approval from the Washington State Department of Fisheries. 
1 13.1.2.8 New Source Construction Permits. Before a new or modified source of regulated air emissions is constructed, installed, or established, Ecology (for nonradioactive emissions) or the Washington State Department of Health (for radioactive emissions) must review plans, specifications, associated information, and Notice of Construction (NOC) related to the new or modified source. A NOC is a written application to permit construction of a new source or modification of an existing source. The application describes the proposed design, assesses potential impacts to the public and environment, and provides an assessment of best available control technology. A NOC for air emissions could be required because of requirements of the following regulations: WAC 173-400 (including 40 CFR 60 and 61), WAC 173-460, and WAC 246-247.

\subsubsection{Septic System Approvals/Permits. Plans and specifications for construction of a new sanitary} sewer system or modification of an existing system are submitted and approved by the Washington State Department of Health before construction or entering into a contract for construction. Septic systems with design capacities greater than 54,888 liters per day are governed by State Waste Discharge Permits (WAC 173-216) and the engineering report, plan, and specification approval process described in WAC 173-240.

13.1.2.10 Dam Safety Regulations. The Dam Safety regulations contained in WAC 173-175 are administrated by Ecology. The regulations are applicable to dams that can impound a volume of 1.23 hectare-meters or more of water as measured at the dam crest elevation. For the Hanford Site, the regulations potentially could apply to disposal basins, retention basins, lined lagoons, etc., if DOE constructs dams and fails to develop a dam safety program for periodic inspection of completed projects. The 1.23 hectare-meters threshold applies to dams that can impound water on either an intermittent or permanent basis.

13.1.2.11 Model Toxics Control Act. Regulations are promulgated in WAC 173-303-340, as amended.

\subsubsection{Local Requirements}

This section contains a brief description of local requirements (e.g., those administered by Benton County or the city of Richland) that could be applicable to the Hanford Facility. Permits and approvals prepared in response to these requirements are identified in the Annual Status Report.

13.1.3.1 Building Permit. Local building permits are not required for construction on the Hanford Site. New construction on the Hanford Site is designed and constructed in accordance with the requirements set forth in U.S. Department of Energy Order 6430.1A.

13.1.3.2 Grading Permit. Local grading permits are not required on the Hanford Site. Excavation permits are issued internally in accordance with the requirements set forth in U.S. Department of Energy Order 5400.1 .

13.1.3.3 Waste Water Pretreatment Discharge Authorization. A permit application could be required before discharging sewage, industrial waste, or other waste to the city of Richland's sewage treatment plant. The need for a permit application depends on whether the activity is considered a Significant Industrial Discharge by the city or fits a national pretreatment category. Permits applications are not required for discharges that fall within one of the national pretreatment categories. 
1 13.1.3.4 Washington Shoreline Management Act of 1971. The Washington Shoreline Management Act 2 regulates development or construction affecting the shorelines of the State. A permit for developing the 3 shoreline is required before construction for shorelines not federally owned, but under lease, easement, 4 license, or other similar federal property rights short of fee ownership. The Washington Shoreline

5 Management Act provisions are administered by the Benton County Planning Commission.

13.1.3.5 Benton Clean Air Authority Regulation 1. Regulation 1 of the Benton Clean Air Authority is divided into various sections termed articles that address odors, dust, open burning, and asbestos regulations. Ecology has delegated authority to the Benton Clean Air Authority to enforce the state regulations governing open burning and asbestos.

\subsection{STATE ENVIRONMENTAL POLICY ACT}

A SEPA determination is used by Washington State regulatory agencies to decide whether a proposed action is likely to have significant or nonsignificant adverse environmental impact. A SEPA Environmental Checklist for the Hanford Facility Dangerous Waste Permit Application, General Information Portion (this document) was prepared in accordance with WAC 197-11-960 and submitted with the application in October 1991. On January 21, 1992, Ecology issued a letter documenting that a determination of nonsignificance was made for the issuance of a dangerous waste management permit for the Hanford Facility. Therefore, the SEPA Environmental Checklist requirements noted in Section $\mathrm{J}$ of Ecology's permit application requirements have been fulfilled for the General Information Portion of the permit application. The SEPA Environmental Checklists for individual TSD units either are contained, or referenced, in the Unit-Specific Portion of this permit application or in closure plan, closure/postclosure plan, or postclosure permit application documentation. 
Table 13-1. Summary of Other Federal and State Laws and Local Requirements That Could Be Applicable to the Hanford Facility. (sheet 1 of 5)

2

\begin{tabular}{|c|c|c|c|}
\hline Chapter section & Law/requirement & Agency & Regulated media, activity \\
\hline 13.1.1.1 & Atomic Energy Act of 1954 & U.S. Department of Energy & Radioactive waste disposal. \\
\hline 13.1.1.2 & $\begin{array}{l}\text { Federal Facility Compliance Act } \\
\text { of } 1992\end{array}$ & $\begin{array}{l}\text { U.S. Environmental Protection } \\
\text { Agency }\end{array}$ & $\begin{array}{l}\text { Waives sovereign immunity from RCRA for } \\
\text { federal facilities. }\end{array}$ \\
\hline 13.1.1.3 & Clean Air Act of 1977 (CAA) & $\begin{array}{l}\text { U.S. Environmental Protection } \\
\text { Agency }\end{array}$ & $\begin{array}{l}\text { Air emissions, ambient air quality, and asbestos; } \\
\text { requires permits for air pollution sources. }\end{array}$ \\
\hline 13.1.1.4 & Clean Water Act of 1977 (CWA) & $\begin{array}{l}\text { U.S. Environmental Protection } \\
\text { Agency }\end{array}$ & $\begin{array}{l}\text { Water quality of surface waters; requires permits } \\
\text { for discharge of liquid effluents to surface waters } \\
\text { and for dredge or fill activities in "waters of the } \\
\text { United States"; provides for protection of wet } \\
\text { lands. }\end{array}$ \\
\hline 13.1 .1 .4 & Clean Water Act of 1977 & U.S. Army Corps of Engineers & $\begin{array}{l}\text { Dredge and fill permits; } \\
\text { wet lands protection. }\end{array}$ \\
\hline 13.1.1.5 & $\begin{array}{l}\text { Safe Drinking Water Act of } 1974 \\
\text { (SDWA) }\end{array}$ & $\begin{array}{l}\text { U.S. Environmental Protection } \\
\text { Agency }\end{array}$ & $\begin{array}{l}\text { Sets drinking water standards and protects } \\
\text { groundwater; regulates underground injection } \\
\text { wells. }\end{array}$ \\
\hline 13.1.1.6 & $\begin{array}{l}\text { Comprehensive Environmental } \\
\text { Response, Compensation, and } \\
\text { Liability Act of } 1980 \text { (CERCLA) }\end{array}$ & $\begin{array}{l}\text { U.S. Environmental Protection } \\
\text { Agency }\end{array}$ & $\begin{array}{l}\text { Requires reporting of spills, releases; requires } \\
\text { cleanup of historic disposal of hazardous wastes or } \\
\text { substances. }\end{array}$ \\
\hline 13.1.1.6 & CERCLA & U.S. Department of Interior & $\begin{array}{l}\text { Establish criteria for the natural resource damage } \\
\text { assessment process. }\end{array}$ \\
\hline 13.1.1.6 & $\begin{array}{l}\text { Superfund Amendments and } \\
\text { Reauthorization Act of } 1986\end{array}$ & $\begin{array}{l}\text { U.S. Environmental Protection } \\
\text { Agency }\end{array}$ & Updates and amends CERCLA. \\
\hline 13.1.1.7 & $\begin{array}{l}\text { Emergency Planning and } \\
\text { Community Right-to-Know Act of } \\
1986 \text { (EPCRA) }\end{array}$ & $\begin{array}{l}\text { U.S. Environmental Protection } \\
\text { Agency }\end{array}$ & $\begin{array}{l}\text { Requires emergency planning, emergency release } \\
\text { notification, community right-to-know reporting, } \\
\text { and toxic chemical release and inventory reporting. }\end{array}$ \\
\hline 13.1 .1 .8 & $\begin{array}{l}\text { Toxic Substances Control Act of } \\
1976\end{array}$ & EPA & $\begin{array}{l}\text { Polychlorinated biphenyls (PCBs) and newly } \\
\text { manufactured chemicals. }\end{array}$ \\
\hline 13.1.1.9 & $\begin{array}{l}\text { Wild and Scenic Rivers Act of } \\
1968\end{array}$ & U.S. Department of Interior & Activity impact to Wild and Scenic Rivers. \\
\hline
\end{tabular}


Table 13-1. Summary of Other Federal and State Laws and Local Requirements That Could Be Applicable to the Hanford Facility. (sheet 2 of 5)

\begin{tabular}{|c|c|c|c|}
\hline Chapter section & Law/requirement & Agency & Regulated media, activity \\
\hline I3.1.1.10 & Hanford Reach Study Act of 1988 & $\begin{array}{l}\text { U.S. Department of } \\
\text { Interior-National Park Service }\end{array}$ & Hanford Reach of the Columbia River. \\
\hline 13.1.1.11 & Rivers and Harbors Act of 1899 & U.S. Army Corps of Engineers & Construction of river obstructions. \\
\hline 13.1.1.12 & $\begin{array}{l}\text { National Historic Preservation } \\
\text { Act of } 1966\end{array}$ & $\begin{array}{l}\text { U.S. Department of } \\
\text { Interior-Advisory Council on } \\
\text { Historic Preservation }\end{array}$ & Historical sites, buildings, and areas. \\
\hline 13.1.1.12 & $\begin{array}{l}\text { National Historic Preservation } \\
\text { Act of } 1966\end{array}$ & $\begin{array}{l}\text { Washington Department of } \\
\text { Community Development }\end{array}$ & $\begin{array}{l}\text { Consultation of federal agency projects/activities } \\
\text { that may impact historic buildings, etc. }\end{array}$ \\
\hline 13.1.1.12 & American Antiquities Act of 1906 & $\begin{array}{l}\text { U.S. Department of } \\
\text { Interior-Advisory Council on } \\
\text { Historic Preservation }\end{array}$ & Historical antiquities. \\
\hline 13.1.1.12 & $\begin{array}{l}\text { Historic Sites, Buildings and } \\
\text { Antiquities Act of } 1935\end{array}$ & $\begin{array}{l}\text { U.S. Department of } \\
\text { Interior-Advisory Council on } \\
\text { Historic Preservation }\end{array}$ & Historical sites, buildings, and antiquities. \\
\hline 13.1.1.12 & $\begin{array}{l}\text { Archaeological and Historic } \\
\text { Preservation Act of } 1960\end{array}$ & $\begin{array}{l}\text { U.S. Department of } \\
\text { Interior-Advisory Council on } \\
\text { Historic Preservation }\end{array}$ & Archaeological resources. \\
\hline 13.1.1.12 & $\begin{array}{l}\text { Archeological Resources } \\
\text { Protection Act of } 1979\end{array}$ & $\begin{array}{l}\text { U.S. Department of } \\
\text { Interior-Advisory Council on } \\
\text { Historic Preservation }\end{array}$ & Archeological resources. \\
\hline 13.1.1.12 & $\begin{array}{l}\text { American Indian Religious } \\
\text { Freedom Act of } 1978\end{array}$ & $\begin{array}{l}\text { U.S. Department of } \\
\text { Interior-Advisory Council on } \\
\text { Historic Preservation }\end{array}$ & American Indian religious activities and areas. \\
\hline 13.1.1.13 & Endangered Species Act of 1973 & $\begin{array}{l}\text { U.S. Department of } \\
\text { Interior-Advisory Council on } \\
\text { Historic Preservation }\end{array}$ & $\begin{array}{l}\text { All species of plants and animals listed as } \\
\text { endangered and their habitats. }\end{array}$ \\
\hline 13.1.1.14 & $\begin{array}{l}\text { Fish and Wildlife Coordination } \\
\text { Act of } 1934\end{array}$ & $\begin{array}{l}\text { U.S. Department of Interior-Fish } \\
\text { and Wildlife Service }\end{array}$ & Fish and wildlife resources and habitats. \\
\hline 13.1.1.14 & $\begin{array}{l}\text { Migratory Bird and Treaty Act of } \\
1918\end{array}$ & $\begin{array}{l}\text { U.S. Department of Interior-Fish } \\
\text { and Wildlife Service }\end{array}$ & All migratory birds and habitats. \\
\hline
\end{tabular}


1 Table 13-1. Summary of Other Federal and State Laws and Local Requirements That Could Be Applicable to the Hanford Facility. (sheet 3 of 5 )

2

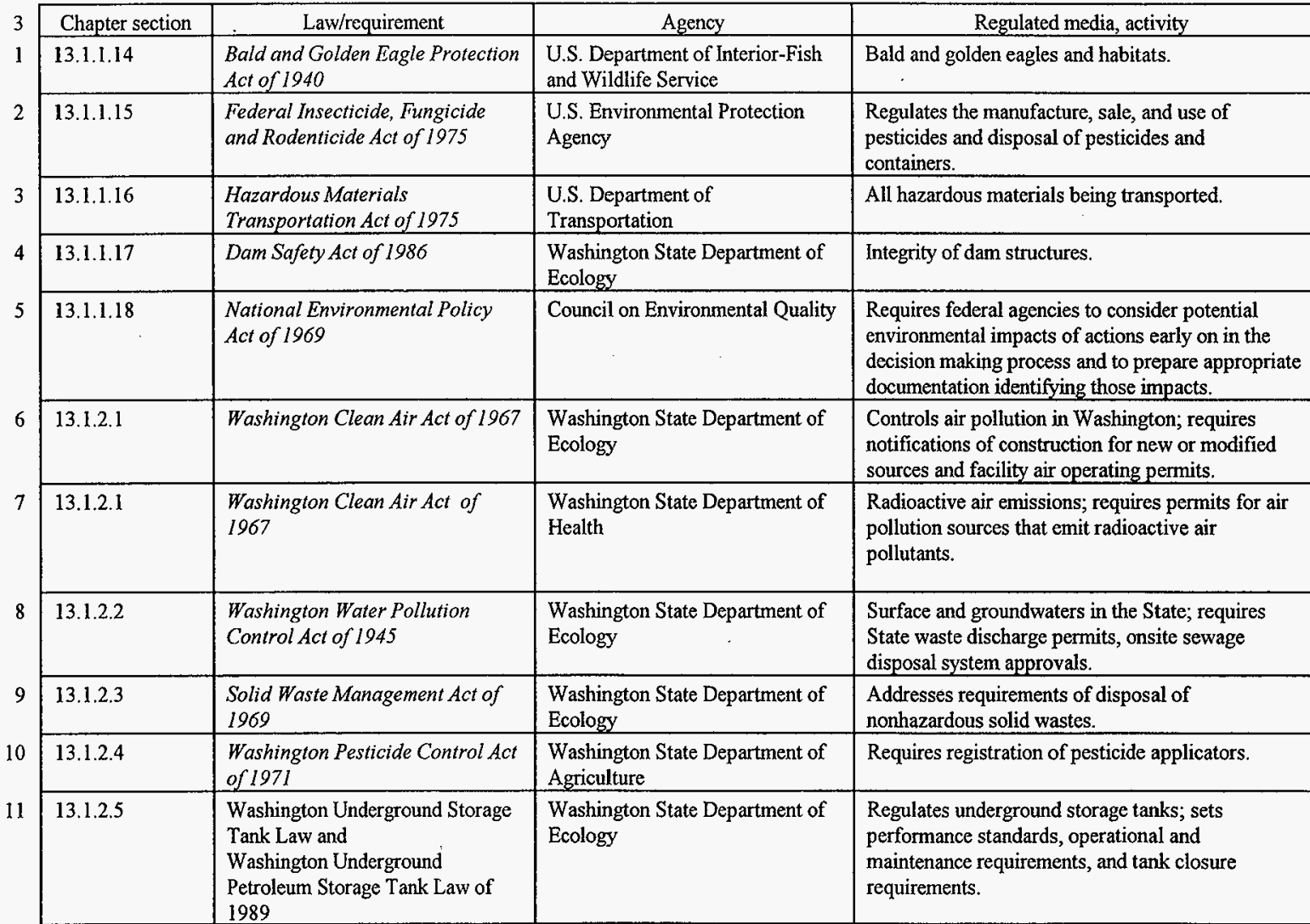


Table 13-1. Summary of Other Federal and State Laws and Local Requirements That Could Be Applicable to the Hanford Facility. (sheet 4 of 5 )

\begin{tabular}{|l|l|l|l|}
\hline Chapter section & \multicolumn{1}{|c|}{ Law/requirement } & \multicolumn{1}{c|}{ Agency } & \multicolumn{1}{c|}{ Regulated media, activity } \\
\hline 13.1.2.6 & Aquatic Land Leases & $\begin{array}{l}\text { Washington State Department of } \\
\text { Natural Resources }\end{array}$ & $\begin{array}{l}\text { Impacts activitics that interfere with state-owned } \\
\text { tidelands, shorelands, and beds of navigable } \\
\text { waters. }\end{array}$ \\
\hline 13.1.2.7 & Hydraulic Projects Permits & $\begin{array}{l}\text { Washington State Department of } \\
\text { Fisheries }\end{array}$ & $\begin{array}{l}\text { Impacts construction or activity that will change } \\
\text { natural flow of a river. }\end{array}$ \\
\hline
\end{tabular}

\begin{tabular}{|l|l|l}
\hline 13.1.2.8 & New Source Construction Permits
\end{tabular}

Washington State Department of Ecology (nonradioactive emissions) and Washington State Department of Health (radioactive emissions)

4

\begin{tabular}{|l|l|l|}
\hline 13.1.2.9 & Septic System Approvals/Permits & Washington State Department of
\end{tabular}
Health (less than or equal to 54,888 liters per day) Washington State Department of Ecology (greater than 54,888 liters per day)

\begin{tabular}{|l|l|l|}
\hline 13.1 .2 .10 & Dam Safety Regulations & $\begin{array}{l}\text { Washington State Department of } \\
\text { Ecology }\end{array}$ \\
\hline
\end{tabular}

7

\begin{tabular}{|l|l|l|l|}
\hline 13.1.2.11 & Model Toxics Control Act & $\begin{array}{l}\text { Washington State Department of } \\
\text { Ecology }\end{array}$ & $\begin{array}{l}\text { All media: WAC 173-340 will be used to set } \\
\text { cleanup standards for closure of TSD units as } \\
\text { specified in WAC 173-303-610. }\end{array}$ \\
\hline 13.1.3.1 & Building Permit & U.S. Department of. Energy & $\begin{array}{l}\text { Requires Hanford construction in accordance with } \\
\text { U.S. Department of Energy requirements. }\end{array}$ \\
\hline 13.1.3.2 & Grading Permit & U.S. Department of Energy & $\begin{array}{l}\text { Requires excavation activities at Hanford to } \\
\text { comply with U.S. Department of Energy } \\
\text { requirements. }\end{array}$ \\
\hline 13.1.3.3 & $\begin{array}{l}\text { Waste Water Pretreatment } \\
\text { Discharge Authorization }\end{array}$ & $\begin{array}{l}\text { Washington State Department of } \\
\text { Ecology }\end{array}$ & $\begin{array}{l}\text { Requires certain conditions be met for waste water } \\
\text { discharges to publicly owned treatment works. }\end{array}$ \\
\hline 13.1.3.4 & $\begin{array}{l}\text { Washington Shoreline } \\
\text { Management Act of 1971 }\end{array}$ & $\begin{array}{l}\text { Benton County Planning } \\
\text { Commission }\end{array}$ & $\begin{array}{l}\text { Regulates development or construction affecting } \\
\text { the shorelines of the State. }\end{array}$ \\
\hline
\end{tabular}

Could affect Hanford if U.S. Department of Energy constructs dams and fails to develop a dam safety program.

Requires submittal and approval for plans and specifications for construction and/or modification of sewage systems.

Impacts new and modified sources of regulated air emissions. the shorelines of the State. 
1 Table 13-1. Summary of Other Federal and State Laws and Local Requirements That Could Be Applicable to the Hanford Facility. (sheet 5 of 5 )

\begin{tabular}{|l|l|l|l|l|}
\cline { 3 - 5 } 3 & Chapter section & \multicolumn{1}{|c|}{ Law/requirement } & \multicolumn{1}{c|}{ Agency } & \multicolumn{1}{c|}{ Regulated media, activity } \\
\cline { 2 - 5 } & 13.1 .3 .5 & $\begin{array}{l}\text { Benton Clean Air Authority } \\
\text { Regulation 1 }\end{array}$ & Benton Clean Air Authority & $\begin{array}{l}\text { Imposes restrictions on odors, dust, open burning, } \\
\text { and asbestos management. }\end{array}$ \\
\cline { 2 - 5 } & $\begin{array}{l}\text { Many federal and state laws require } \\
\text { consultation with other agencies on } \\
\text { a variety of issues and } \\
\text { requirements which result in } \\
\text { additional regulatory requirements. }\end{array}$ & Other federal and state agencies & $\begin{array}{l}\text { Examples include consultations with state and } \\
\text { other federal agencies on CERCLA actions to } \\
\text { determine applicable, relevant, and appropriate } \\
\text { regulatory requirements for cleanup activities and } \\
\text { the CERCLA requirement that DOE notify and } \\
\text { coordinate with other natural resource trustees on } \\
\text { potential damages. }\end{array}$ \\
\hline
\end{tabular}

3 
DOE/RL-91-28, Rev. 4

$05 / 98$

\section{CONTENTS}

2

3

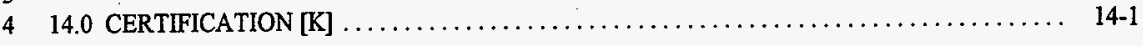

5 
DOE/RL-91-28, Rev. 4

$05 / 98$

This page intentionally left blank. 


\subsection{CERTIFICATION [K]}

I certify under penalty of law that this document and all attachments were prepared under my direction or supervision in accordance with a system designed to assure that qualified personnel properly gather and evaluate the information submitted. Based on my inquiry of the person or persons who manage the system, or those persons directly responsible for gathering the information, the information submitted is, to the best of my knowledge and belief, true, accurate, and complete. I am aware that there are significant penalties for submitting false information, including the possibility of fine and imprisonment for knowing violations.
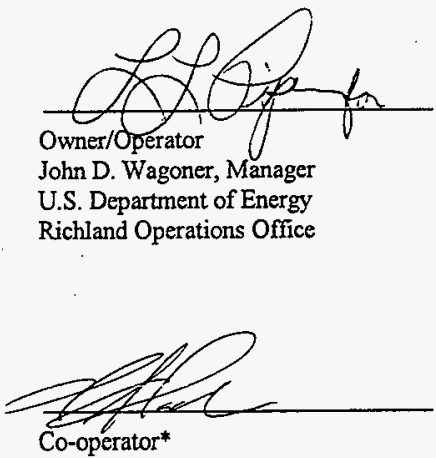

H. J. Hatch,

President and Chief Executive Officer

Fluor Daniel Hanford, Inc.
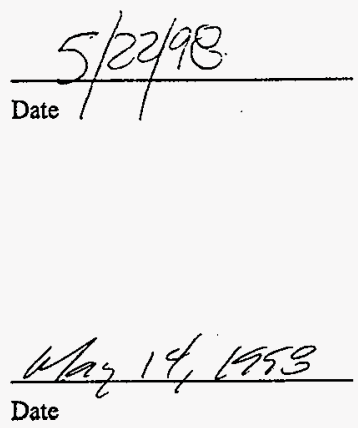

* Fluor Daniel Hanford, Inc. has responsibilities for the following treatment, storage, and/or disposal units on the Hanford Facility and is signing for the purpose of these units only: Double-Shell Tank System, 204-AR Waste Unloading Station, 242-A Evaporator, 222-S Laboratory Complex, 200 Area Effluent Treatment Facility, Liquid Effluent Retention Facility, Central Waste Complex, Waste Receiving and Processing 1, Low-Level Burial Grounds, 224-T Transuranic Waste Storage and Assay Facility, T Plant Complex, 616 Nonradioactive Dangerous Waste Storage Facility, PUREX Storage Tunnels, 207-A South Retention Basin, 216-B-63 Trench, 105-DR Large Sodium Fire Facility, 3718-F Alkali Metal Treatment and Storage Area, 300 Area Waste Acid Treatment System, 303-M Oxide Facility, 303-K Storage Unit, PUREX Plant, 241-Z Treatment and Storage Tanks, B Plant Complex, 1706-KE Waste Treatment System, 221-T Containment Systems Test Facility, 2727-WA Sodium Reactor Experiment Sodium Storage Building, 437 Maintenance and Storage Facility, Sodium Storage Facility and Sodium Reaction Facility, 600 Area Purgewater Storage and Treatment Facility, Single-Shell Tank System, Grout Treatment Facility, Waste Encapsulation and Storage Facility, and the Hanford Waste Vitrification Plant. 
This page intentionally left blank. 


\subsection{CERTIFICATION [K]}

I certify under penalty of law that this document and all attachments were prepared under my direction or supervision in accordance with a system designed to assure that qualified personnel properly gather and evaluate the information submitted. Based on my inquiry of the person or persons who manage the system, or those persons directly responsible for gathering the information, the information submitted is, to the best of my knowledge and belief, true, accurate, and complete. I am aware that there are significant penalties for submitting false information, including the possibility of fine and imprisonment for knowing violations.

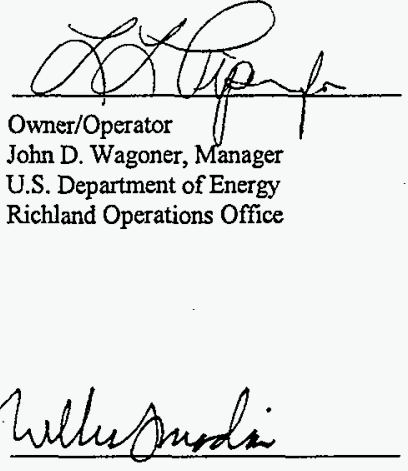

Co-operator*

William J. Madia, Director

Pacific Northwest National Laboratory

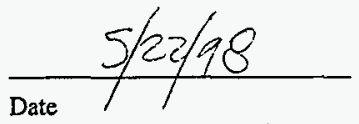

Date

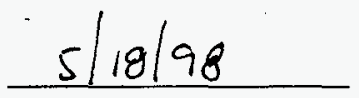

Date

* Pacific Northwest National Laboratory has responsibilities for the following treatment, storage, and/or disposal units on the Hanford Facility and is signing for the purpose of these units only: 325 Hazardous Waste Treatment Units, 305-B Storage Unit, and the groundwater monitoring plans as required by the groundwater sections of the Low-Level Burial Grounds and Liquid Effuent Retention Facility. 
DOE/RL-91-28, Rev. 4

05/98

This page intentionally left blank. 


\subsection{CERTIFICATION $[\mathrm{K}]$}

I certify under penalty of law that this document and all attachments were prepared under my direction or supervision in accordance with a system designed to assure that qualified personnel properly gather and evaluate the information submitted. Based on my inquiry of the person or persons who manage the system, or those persons directly responsible for gathering the information, the information submitted is, to the best of my knowledge and belief, true, accurate, and complete. I am aware that there are significant penalties for submitting false information, including the possibility of fine and imprisonment for knowing violations.
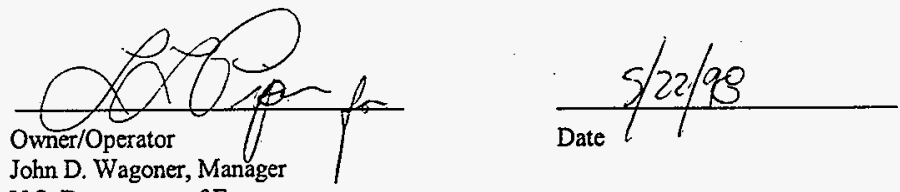

U.S. Department of Energy

Richland Operations Office

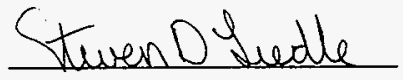

Co-operator*

Steven D. Liedle, President

Bechtel Hanford, Inc.
* Bechtel Hanford, Inc. has responsibilities for the following treatment, storage, and/or disposal units on the Hanford Facility and is signing for the purpose of these units only: Hexone Storage and Treatment Facility, 241-CX Tank System, 183-H Solar Evaporation Basins, 1324-N Surface Impoundment, 1301-N Liquid Waste Disposal Facility, 1325-N Liquid Waste Disposal Facility, 1324-NA Percolation Pond, 100-D Ponds, 216-S-10 Pond and Ditch, 216-A-29 Ditch, 216-B-3 Main Pond, 216-A-10 Crib, 216-U-12 Crib, 216-A-36B Crib, 216-A-37-1 Crib, 300 Area Process Trenches, and the Nonradioactive Dangërous Waste Landfill. 
DOE/RL-91-28, Rev. 4

$05 / 98$

This page intentionally left blank. 
DOE/RL-91-28, Rev. 4 $05 / 98$

\section{CONTENTS}

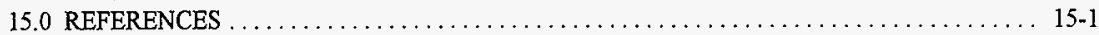

5

6 
DOE/RL-91-28, Rev. 4

$05 / 98$

This page intentionally left blank. 


\subsection{REFERENCES}

AASHTO, 1983, Standard Specification for Highway Bridges, AASHTO-HS 20-44, American Association of Highway and Transportation Officials, Washington, D.C.

ASTM, PS64-96, Provisional Standard Guide for Developing Appropriate Statistical Approaches for Ground-Water Detection Monitoring Programs, American Society for Testing and Materials, West Conshohocken, PA.

COE, 1969, Columbia River Basin: Lower Columbia River Standard Project Flood and Probable Maximum Flood, Memorandum Report, U.S. Army Corps of Engineers, North Pacific Division, Portland, Oregon.

DOE/EIS-0113, Final Environmental Impact Statement, Disposal of Hanford Defense High-Level, Transuranic and Tank Wastes, U.S. Department of Energy, Washington, D.C.

DOE/EIS-0222, Draft Hanford Remedial Action Environmental Impact Statement and Comprehensive Land Use Plan, U.S. Department of Energy, Washington, D.C.

DOE Order 5400.1, General Environmental Protection Program.

DOE Order 5820.2A, Radioactive Waste Management.

DOE Order 6430.1A, General Design Criteria.

DOE/RL-88-20, Hanford Facility Dangerous Waste Permit Application, Low-Level Burial Grounds U.S. Department of Energy, Richland Operations Office, Richland, Washington.

DOE/RL-88-21, Hanford Facility Dangeraus Waste Part A Permit Application, Vol. 1-3, U.S. Department of Energy, Richland Operations Office, Richland, Washington, updated periodically.

DOE/RL-88-27, Grout Treatment Facility Dangerous Waste Permit Application, U.S. Department of Energy, Richland Operations Office, Richland, Washington.

DOE/RL-88-30, Hanford Site Waste Management Units Report, Vols. 1-2, U.S. Department of Energy, Richland Operations Office, Richland, Washington, updated annually.

DOE/RL-89-02, Hanford Waste Vitrification Plant Dangerous Waste Permit Application, U.S. Department of Energy, Richland Operations Office, Richland, Washington.

DOE/RL-89-03, 616 Nonradioactive Dangerous Waste Storage Facility Dangerous Waste Permit Application, U.S. Department of Energy, Richland Operations Office, Richland, Washington.

DOE/RL-89-12, Hanford Site Ground Water Protection Management Plan, U.S. Department of Energy, Richland Operations Office, Richland, Washington.

DOE/RL-89-16, Single-Shell Tank Closure Work Plan, U.S. Department of Energy, Richland Operations Office, Richland, Washington. 
1 DOE/RL-90-01, 305-B Storage Unit Dangerous Waste Permit Application, U.S. Department of Energy, 2 Richland Operations Office, Richland, Washington.

DOE/RL-90-24, Hanford Facility Dangerous Waste Permit Application, PUREX Storage Tunnels, U.S. Department of Energy, Richland Operations Office, Richland, Washington.

DOE/RL-90-39, Double-Shell Tanks Dangerous Waste Permit Application, U.S. Department of Energy, Richland Operations Office, Richland, Washington.

DOE/RL-90-41, Hanford Land Disposal Restriction Plan for Mixed Waste, U.S. Department of Energy, Richland Operations Office, Richland, Washington.

DOE/RL-90-42, 242-A Evaporator Dangerous Waste Permit Application, U.S. Department of Energy, Richland Operations Office, Richland, Washington.

DOE/RL-91-03, Annual Report for RCRA Groundwater Monitoring Projects at Hanford Site Facilities for 1990, U.S. Department of Energy, Richland Operations Office, Richland, Washington.

DOE/RL-91-16, Hanford Facility Dangerous Waste Permit Application, Waste Receiving and Processing Facility, U.S. Department of Energy, Richland Operations Office, Richland, Washington.

DOE/RL-91-17, Hanford Facility Dangerous Waste Permit Application, Central Waste Complex, U.S. Department of Energy, Richland Operations Office, Richland, Washington.

DOE/RL-91-27, 222-S Laboratory Complex Dangerous Waste Permit Application, U.S. Department of Energy, Richland Operations Office, Richland, Washington.

DOE/RL-91-45, Hanford Site Baseline Risk Assessment Methodology, U.S. Department of Energy, Richland Operations Office, Richland, Washington.

DOE/RL-91-50, Hanford Site Environmental Monitoring Plan, U.S. Department of Energy, Richland Operations Office, Richland, Washington.

DOE/RL-91-51, 24I-T Transuranic Waste Storage and Assay Facility Dangerous Waste Permit Application, U.S. Department of Energy, Richland Operations Office, Richland, Washington.

DOE/RL-92-23, Hanford Site Groundwater Background, U.S. Department of Energy, Richland Operations Office, Richland, Washington.

DOE/RL-92-24, Hanford Site Soil Background, U.S. Department of Energy, Richland Operations Office, Richland, Washington.

DOE/RL-92-35, Hanford Facility Dangerous Waste Permit Application, 325 Hazardous Waste Treatment Units, U.S. Department of Energy, Richland Operations Office, Richland, Washington.

DOE/RL-93-102, Hanford Mission Plan, U.S. Department of Energy, Richland Operations Office, Richland, Washington. 
DOE/RL-94-02, Hanford Emergency Response Plan, U.S. Department of Energy, Richland Operations Office, Richland, Washington.

DOE/RL-94-95, Hanford Sitewide Groundwater Remediation Strategy, U.S. Department of Energy, Richland Operations Office, Richland, Washington.

DOE/RL-95-15, 1995 Report on Hanford Site Land Disposal Restrictions for Mixed Waste, U.S. Department of Energy, Richland Operations Office, Richland, Washington.

DOE/RL-95-36, Hanford Facility Dangerous Waste Permit Application, T Plant Complex, U.S. Department of Energy, Richland Operations Office, Richland, Washington.

DOE/RL-95-78, PUREX Facility Preclosure Work Plan, U.S. Department of Energy, Richland Operations Office, Richland, Washington.

DOE/RL-96-50, Hanford Facility RCRA Permit Condition II.U.I Report for Mapping and Marking of Dangerous Waste Underground Pipelines, U.S. Department of Energy, Richland Operations Office, Richland, Washington.

DOE/RL-96-61, Hanford Site Background: Part 3, Groundwater Background, U.S. Department of Energy, Richland Operations Office, Richland, Washington.

DOE/RL-96-63, Annual Hanford Site Environmental Permitting Status Report, Rev. 1, U.S. Department of Energy, Richland Operations Office, Richland, Washington.

DOE/RL-96-82, Hanford Facility Dangerous Waste Closure Plan, 241-Z Treatment and Storage Tanks, Rev. 0, U.S. Department of Energy, Richland Operations Office, Richland, Washington.

DOE/RL-96-92, Hanford Strategic Plan, U.S. Department of Energy, Richland Operations Office, Richland, Washington.

DOE/RL-97-03, Hanford Facility Dangerous Waste Permit Application, Liquid Effluent Retention Facility and 200 Area Effluent Treatment Facility, U.S. Department of Energy, Richland Operations Office, Richland, Washington.

DOE-RL, WHC, PNL, 1994, Hanford Site Comments on the Second Draft of the Resource Conservation and Recovery Act for the Treatment, Storage, and Disposal of Dangerous Waste for the Hanford Facility, letter number 94-RPS-185, to U.S. Environmental Protection Agency, Region 10, and Washington State Department of Ecology dated April 6, 1994.

DOE/RW-0164, Site Characterization Plan, Reference Repository Location, Hanford Site, Washington, Consultation Draft, Vol. 1-9, Office of Civilian Radioactive Waste Management, U.S. Department of Energy, Washington, D.C.

Ecology No. DE 86-133, Consent Agreement and Compliance Order, PCHB No. 86-44, Washington State Department of Ecology, Olympia, Washington.

Ecology, 1987, State of Washington Part B Permit Application Requirements, Washington State Department of Ecology, Olympia, Washington. 
1 Ecology, 1996, Dangerous Waste Permit Application Requirements, Publication Number \#95-402,

Ecology, EPA, and DOE-RL, 1994, Cost and Management Efficiency Initiative, Washington State Department of Ecology, U.S. Environmental Protection Agency, U.S. Department of Energy, Richland Operations Office, Olympia, Washington,

Ecology, EPA, and DOE-RL, 1996, Hanford Federal Facility Agreement and Consent Order, Washington State Department of Ecology, U.S. Environmental Protection Agency, U.S. Department of Energy, Richland Operations Office, Olympia, Washington, amended periodically.

EPA, 1986a, Permit Applicants' Guidance Manual for Exposure Information Requirements under RCRA Section 3019, Office of Solid Waste, U.S. Environmental Protection Agency, Washington, D.C.

EPA, 1986b, RCRA Ground Water Monitoring Technical Enforcement Guidance Document (TEGD), National Water Well Association, Dublin, Ohio.

EPA, 1989a, Integrated Risk Information System Database, Dialcom, U.S. Environmental Protection Agency, Silver Springs, Maryland, updated quarterly.

EPA, 1989b, Risk Assessment Guidance for Superfund: Human Health Evaluation Manual, Part A, Interim Final, U.S. Environmental Protection Agency, Washington, D.C.

EPA, 1992, Draft Addendum to Interim Final Guidance, U.S. Environmental Protection Agency, Washington, D.C.

EPA/230/02-89-042, Methods for Evaluating the Attainment of Cleanup Standards, Vol. 1: Soils \& Solid Media, 230/02-89-042, U.S. Environmental Protection Agency, Office of Policy, Planning and Evaluation, Washington, D.C.

EPA/530-SW-89-026, Statistical Analysis of Ground-Water Monitoring Data at RCRA Facilities, Interim Final Guidance, U.S. Envirommental Protection Agency, Washington, D.C.

EPA540-R-93-0071, Data Quality Objectives Process for Superfund Interim Final Guidance, U.S. Environmental Protection Agency, Washington, D.C.

EPA 600/2-85-104, Practical Guide for Ground-Water Sampling, Robert S. Kerr Environmental Research Laboratory, Ada, Oklahoma.

EPAV00/R-96/055, Guidance for the Data Quality Objectives Process, U.S. Environmental Protection Agency, Washington, D.C.

EPA PB94-963-603, Waste Analysis at Facilities that Generate, Treat, Store, and Dispose of Hazardous Wastes: A Guidance Manual, U.S. Environmental Protection Agency, Washington, D.C. 
EPA SW-846, Test Methods for the Evaluation of Solid Waste: Physical/Chemical Methods, latest edition, U.S. Environmental Protection Agency, Washington, D.C.

EPA and Ecology, 1990, "Policy on Remediation of Existing Wells and Acceptance Criteria for RCRA and CERCLA", Letter dated 7/16/90, from T.L. Nord (Ecology) and P.T. Day (EPA) to S.H. Wisness (DOE-RL).

FEMA, 1980, Flood Insurance Study: Benton County Washington, Federal Emergency Management Agency, Federal Insurance Administration, Washington, D.C.

Freeze, R.A. and J.A. Cherry, 1979, Groundwater, Prentice-Hall, Inc., Englewood Cliffs, New Jersey.

Gee, et al., 1992, "Variations in Recharge at the Hanford Site", Northwest Science, Vol. 66.

ICBO, 1991, "Earthquake Regulations," Uniform Building Code, UBC Section 2312, International Conference of Building Officials, Whittier, California.

ICF KH ENG-W-95-2160, RCRA Mapping and Marking on the Hanford Site Value Engineering Report, Rev. 0, ICF Kaiser Hanford Company, Richland, Washington.

Lyman, W.J., W.F. Reehl, and D.H. Rosenblatt, 1982, Handbook of Chemical Property Estimation Methods, McGraw-Hill Book Company, New York, New York.

NUREG-0892, Safety Evaluation Report (Related to the Operation of WPPSS Nuclear Project No. 2), Supplement No. I, U.S. Nuclear Regulatory Commission, Washington, D.C.

PNL-4219, Flood Risk Analysis of Cold Creek Near the Hanford Site, Pacific Northwest Laboratory, Richland, Washington.

PNL-4622, Climatological Summary for the Hanford Area, Pacific Northwest Laboratory, Richland, Washington.

PNL-6328, Estimation of Ground-Water Travel Time at the Hanford Site: Description, Past Work, and Future Needs, Pacific Northwest Laboratory, Richland, Washington.

PNL-6415, Hanford Site National Environmental Policy Act (NEPA) Characterization, Pacific Northwest Laboratory, Richland, Washington.

PNL-10651, Development of a Risk Based Approach to Hanford Site Cleanup, Pacific Northwest Laboratory, Richland, Washington.

PNL-11 139, Hanford Site Environmental Report for Calendar Year 1995, Pacific Northwest National Laboratory, Richland, Washington.

PNL, 1992, Estimation of the Release and Transport of Lead through Soils and Groundwater at the Hanford Site 218-E-12B Burial Ground, Pacific Northwest Laboratory, Richland, Washington.

PNL, 1994, Estimation of the Release and Transport of Nickel through Soils and Groundwater at the Hanford Site 218-E-12B Burial Ground, Pacific Northwest Laboratory, Richland, Washington. 
1 PNNL-10285, Estimated Recharge Rates at the Hanford Site, Pacific Northwest National Laboratory, Richland, Washington.

PNNL-1 1793, Hanford Site Groundwater Monitoring for Fiscal Year 1997, Pacific Northwest National Laboratory, Richland, Washington.

RHO-BWI-ST-5, Hydrologic Studies Within the Columbia Plateau, Washington: An Integration of Current Knowledge, Rockwell Hanford Operations, Richland, Washington.

RHO-RE-SR-87-24, Results of the Separations Area Ground-Water Monitoring Network for 1986, Rockwell Hanford Operations; Richland, Washington.

RHO-RE-ST-12P, An Assessment of Aquifer Intercommunication in the B Pond-Gable Mountain Pond Area of the Hanford Site, Rockwell Hanford Operations, Richland, Washington.

RHO-ST-23, Geology of the Separations Areas, Hanford Site, South-Central Washington, Rockwell Hanford Operations, Richland, Washington.

RHO-ST-42, Hydrology of the Separations Area, Rockwell Hanford Operations, Richland, Washington.

RLO-76-4, Evaluation of Impact of Potential Flooding Criteria on the Hanford Project, U.S. Energy Research and Development Administration-Richland Operations Office, Richland, Washington.

Silka, L.R., 1988, "Simulation of Vapor Transport through the Unsaturated Zone-Interpretation of Soil-Gas Surveys", Ground Water Monitoring Review, Vol. VIII, No. 2, pp. 115-123.

USN, 1995, Extrapolation of Migration Modeling for Large Metal Components Containing Lead and Nickel Alloys at the 218-E-12B Burial Ground, U.S. Department of the Navy, Puget Sound Naval Shipyard, Bremerton, Washington.

USN, 1996, Environmental Impact Statement on the Disposal of Decommissioned, Defueled Cruiser, Ohio Class, and Los Angeles Class Naval Reactor Plants, U.S. Department of the Navy, Puget Sound Naval Shipyard, Bremerton, Washington.

WHC-EP-0260, Operational Groundwater Monitoring at the Hanford Site -- 1988, Westinghouse Hanford Company, Richland, Washington.

WHC-EP-0394, Ground Water Maps of the Hanford Site, December 1990, Westinghouse Hanford Company, Richland, Washington.

WHC-S-014, Generic Specification Groundwater Monitoring Wells, Westinghouse Hanford Company, Richland, Washington.

WHC-SA-1124-FP, Statistical Approach on RCRA Groundwater Monitoring Projects at the Hanford Site, Westinghouse Hanford Company, Richland, Washington.

WHC-SD-AP-024, Interim Status Ground-Water Monitoring Plan for the 200 East Area Liquid Effluent Retention Facility, Westinghouse Hanford Company, Richland, Washington. 
WHC-SD-EN-AP-015, Revised Ground-Water Monitoring Plan for the 200 Areas Low-Level Burial Grounds, Westinghouse Hanford Company, Richland, Washington.

WHC-SD-EN-AP-021, Interim-Status Ground-Water Quality Assessment Program Plan for Waste Management Area I of the 200 Areas Low-Level Burial Grounds, Westinghouse Hanford Company, Richland, Washington.

WHC-SD-EN-AP-022, Interim-Status Ground-Water Quality Assessment Program Plan for Waste Management Area 3 of the 200 Areas Low-Level Burial Grounds, Westinghouse Hanford Company, Richland, Washington.

WHC-SD-EN-EE-004, Revised Stratigraphy for the Ringold Formation, Hanford Site, South Central Washington, Westinghouse Hanford Company, Richland, Washington.

WHC-SD-ER-TI-0003, Geology and Hydrology of the Hanford Site: A Standardized Text for Use in Westinghouse Hanford Company Documents and Reports, Westinghouse Hanford Company, Richland, Washington, updated periodically.

WHC-SD-W105-SAR-001, Final Safety Analysis Report 242-A Evaporator Liquid Effluent Retention Facility, Westinghouse Hanford Company, Richland, Washington.

WHC-SD-WM-ISB-002, WHC, 1995, Solid Burial Ground Interim Safety Basis, Westinghouse Hanford Company, Richland, Washington.

WHC-SD-WM-PE-056, 242-A Campaign 95-1 Post Run Document, Westinghouse Hanford Company, Richland, Washington.

59 FR 17091, "Establishment of New Routine Use for an Existing System of Records".

59 FR 55322, "Washington: Final Authorization of State Hazardous Waste Management Program Revisions". 
This page intentionally left blank. 
DOE/RL-91-28, Rev. 4

\section{APPENDICES}

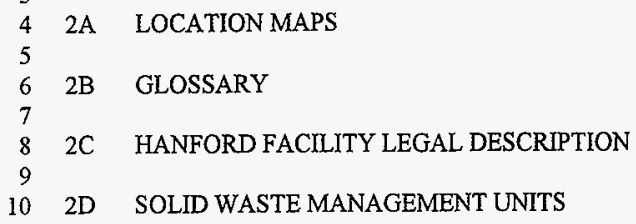


DOE/RL-91-28, Rev. 4

$05 / 98$

This page intentionally left blank. 
DOE/RL-91-28, Rev. 4

05/98

APPENDIX 2A

LOCATION MAPS 


\begin{tabular}{|c|c|c|c|}
\hline \multicolumn{4}{|c|}{ APPENDIX 2A } \\
\hline \multicolumn{4}{|c|}{ CONTENTS } \\
\hline H-6-958 & $\begin{array}{l}\text { General Overview of Hanf } \\
\text { Composite Aerial Photogr } \\
\text { General Locational Maps: } \\
200 \text { West Area, 100-B Are } \\
100-\text { F Area.* }\end{array}$ & $\begin{array}{l}\text { Area, } 400 \\
0 \text {-D Area, } 1\end{array}$ & $\begin{array}{l}200 \text { East Area, } \\
\text { Area, and }\end{array}$ \\
\hline \multicolumn{4}{|c|}{$\begin{array}{l}\text { For specific locational purposes, current maps and information for the Hanford Facility TSD units can } \\
\text { be obtained by contacting HGIS personnel at }(509) 372-9378 \text {. The operable unit location for each TSD unit } \\
\text { is provided in the following table and can be used to facilitate the acquisition of maps through the HGIS. }\end{array}$} \\
\hline \multicolumn{4}{|c|}{ Operable Unit Location. } \\
\hline & TSD unit & Location & Operable unit \\
\hline Double-S & ell Tank System & $200 \mathrm{EW}$ & $\begin{array}{l}200-\mathrm{PO}-3 \\
200-\mathrm{PO}-4 \\
200-\mathrm{IU}-6 \\
200-\mathrm{TP}-5 \\
200-\mathrm{BP}-7 \\
200-\mathrm{UP}-3 \\
200-\mathrm{RO}-2\end{array}$ \\
\hline 204-AR & aste Unloading Station & $200 \mathrm{E}$ & 200-PO-3 \\
\hline 242-A E & porator & $200 \mathrm{E}$ & $200-\mathrm{PO}-3$ \\
\hline 222-S La & oratory Complex & $200 \mathrm{~W}$ & 200-RO-3 \\
\hline 200 Area & fffuent Treatment Facility & $200 \mathrm{E}$ & 200-BP-11 \\
\hline Liquid $\mathrm{E}$ & uent Retention Facility & $200 \mathrm{E}$ & 200-BP-11 \\
\hline Central V & aste Complex & $200 \mathrm{~W}$ & $200-\mathrm{ZP}-3$ \\
\hline Waste Re & eiving and Processing & $200 \mathrm{~W}$ & $200-Z P-3$ \\
\hline Low-Lev & Burial Grounds & $200 \mathrm{EW}$ & $\begin{array}{l}200-B P-10 \\
200-P O-6 \\
200-Z P-3 \\
\end{array}$ \\
\hline $24-T$ & ani & $200 \mathrm{~W}$ & $200-\mathrm{TP}-4$ \\
\hline
\end{tabular}

\section{APPENDIX 2A}

CONTENTS 
Operable Unit Location.

22

23

1

2

3

4

5

6

7

8

\begin{tabular}{|c|c|c|}
\hline TSD unit & Location & Operable unit \\
\hline T Plant Complex & $200 \mathrm{~W}$ & $200-T P-4$ \\
\hline 616 Nonradioactive Dangerous Waste Storage Facility & 600 & $200-\mathrm{IU}-6$ \\
\hline PUREX Storage Tunnels & $200 \mathrm{E}$ & $200-\mathrm{PO}-2$ \\
\hline 325 Hazardous Waste Treatment Units & 300 & $300-F F-2$ \\
\hline 305-B Storage Unit & 300 & $300-F F-2$ \\
\hline 207-A South Retention Basin & $200 \mathrm{E}$ & $200-\mathrm{PO}-5$ \\
\hline 216-B-3 Expansion Ponds & $200 \mathrm{E}$ & 200-BP-11 \\
\hline 216-B-63 Trench & $200 \mathrm{E}$ & 200-BP-8 \\
\hline 200 West Area Ash Pit Demolition Site & $200 \mathrm{~W}$ & 200-SS-2 \\
\hline 218-E-8 Borrow Pit Demolition Site & $200 \mathrm{E}$ & 200-RO-2 \\
\hline Hanford Patrol Academy Demolition Sites & 600 & 1100-EM-1 \\
\hline 2727-S Storage Facility & $200 \mathrm{~W}$ & $200-\mathrm{RO}^{-3}$ \\
\hline 4843 Alkali Metal Storage Facility & 400 & $300-F F-2$ \\
\hline 105-DR Large Sodium Fire Facility & 100 & $100-D R-1$ \\
\hline 3718-F Alkali Metal Treatment and Storage Area & 300 & $300-F F-2$ \\
\hline 304 Concretion Facility & 300 & $300-F F-2$ \\
\hline 300 Area Solvent Evaporator & 300 & 300-FF-2 \\
\hline 300 Area Waste Acid Treatment System & 300 & $300-F F-2$ \\
\hline 303-M Oxide Facility & 300 & $300-F F-2$ \\
\hline 303-K Storage Unit & 300 & $300-F F-2$ \\
\hline 2101-M Pond & $200 \mathrm{E}$ & 200-SS-1 \\
\hline Hexone Storage and Treatment Facility & $200 \mathrm{~W}$ & 200-RO-2 \\
\hline 241-CX Tank System & $200 \mathrm{E}$ & 200-SO-1 \\
\hline 183-H Solar Evaporation Basins & 100 & $100-$ HR-1 \\
\hline 1324-N Surface Impoundment & 100 & $100-\mathrm{NR}-1$ \\
\hline 1301-N Liquid Waste Disposal Facility & 100 & 100-NR-1 \\
\hline 1325-N Liquid Waste Disposal Facility & 100 & 100-NR-1 \\
\hline
\end{tabular}


Operable Unit Location.

TSD unit

L

Location

1324-NA Percolation Pond

2

3

4

5

6

7

\section{0-D Ponds}

216-S-10 Pond and Ditch

216-A-29 Ditch

216-B-3 Main Pond

216-A-10 Crib

216-U-12 Crib

216-A-36B Crib

216-A-37-1 Crib

300 Area Process Trenches

Nonradioactive Dangerous Waste Landfill

Simulated High-Level Waste Slurry Treatment/Storage

PUREX Plant

241-Z Treatment and Storage Tanks

B Plant Complex

Waste Encapsulation and Storage Facility

1706-KE Waste Treatment System

221-T Containment Systems Test Facility

2727-WA Sodium Reactor Experiment Sodium Storage Building

437 Maintenance and Storage Facility

324 Pilot Plant

Biological Treatment Test Facilities

Physical and Chemical Treatment Test Facilities

Thermal Treatment Test Facilities

332 Storage Facility

Sodium Storage Facility and

Sodium Reaction Facility 100
Operable unit 100-NR-1 100-DP-1 200-RO-1 200-PO-5 200-BP-11 200-PO-2 200-UP-2 200-PO-2 200-PO-4 300-FF-1 200-IU-3 1100-EM-3 200-PO-1 200-ZP-1 200-BP-6 200-BP-6 100-KR-2y 220-TP-4 200-UP-2 300-FF-2 300-FF-2 $300-F F-2$ 300-FF-2 300-FF-2 300-FF-1 300-FF-2 
21

22

23

\section{1}

2

\begin{tabular}{|c|c|c|}
\hline TSD unit & Location & Operable unit \\
\hline 600 Area Purgewater Storage and Treatment Facility & 600 & 200-BP-11 \\
\hline Single-Shell Tank System & $200 \mathrm{EW}$ & $\begin{array}{l}200-\mathrm{BP}-7 \\
200-\mathrm{PO}-3 \\
200-\mathrm{RO}-4 \\
200-\mathrm{TP}-5 \\
200-\mathrm{TP}-6 \\
200-\mathrm{UP}-3\end{array}$ \\
\hline Grout Treatment Facility & $200 \mathrm{E}$ & 200-PO-3 \\
\hline Hanford Waste Vitrification Plant & $200 \mathrm{E}$ & $200-B P-9$ \\
\hline
\end{tabular}

Operable Unit Location.

5 
DOE/RL-91-28, Rev. 4

05/98

This page intentionally left blank. 
APPENDLX 2B

GLOSSARY 
DOE/RL-91-28, Rev. 4

$05 / 98$

This page intentionally left blank. 
CERCLA

CFR

CMS

CWC

$D \& D$

DOE-RL

DQO

DST System

DW

15

${ }^{\circ} \mathrm{F}$

ECN

Ecology

EMSL

EPA

FFTF

GTF

HAMMER

HEIS

HEPA

HGIS

HSWA

HWVP

IRIS

LDR

LERF

LIGO

LLBG

$M$

MEMO

MTCA

ONC

\section{GLOSSARY}

Comprehensive Environmental Response, Compensation, and Liability Act of 1980

Code of Federal Regulations

corrective measures study

Central Waste Complex

decontamination and decommissioning

U.S. Department of Energy, Richland Operations Office

data quality objective

Double-Shell Tank System

dangerous waste

${ }^{\circ} \mathrm{C} \quad$ degree Celsius

degree Fahrenheit

engineering change notice

Washington State Department of Ecology

Environmental and Molecular Sciences Laboratory

U.S. Environmental Protection Agency

HF RCRA Permit

Fast Flux Test Facility

Grout Treatment Facility

Hazardous Materials Management and Emergency Response

Hanford Environmental Information System

high-efficiency particulate air

Hanford Facility Resource Conservation and Recovery Act Permit

Hanford Geological Information System

Hazardous and Solid Waste Amendments

Hanford Waste Vitrification Plant

Integrated Risk Information System

land disposal restriction

Liquid Effluent Retention Facility

Laser Interferometer Gravitational Wave Observatory

Low-Level Burial Grounds

Milestone

monitoring efficiency model

Model Toxics Control Act

Occurrence Notification Center 
1 Part A

2 Part B

$3 \mathrm{pH}$

4

5 PUREX

6 Purgewater Facility

7

8

9
Dangerous Waste Part A Permit Application

Dangerous Waste Part B Permit Application

negative logarithm of the hydrogen-ion concentration

plutonium-uranium extraction

600 Area Purgewater Storage and Treatment Facility

quality assurance project plan

Resource Conservation and Recovery Act of 1976

research, development, and demonstration

RCRA facility investigation

single-shell tank

solid waste management unit

Hanford Federal Facility Agreement and Consent Order

treatment, storage, and/or disposal

Tank Waste Remediation System

Uranium Oxide Plant

Washington Administrative Code

Waste Information Data System

Waste Receiving and Processing 1

200 Area Effluent Treatment Facility

204-AR Waste Unloading Station

224-T Transuranic Waste Storage and Assay Facility

241-Z Treatment and Storage Tanks

305-B Storage Facility

325 Hazardous Waste Treatment Units

616 Nonradioactive Dangerous Waste Storage Facility

Accuracy--Relates to the quality of the result, and is distinguished from precision that relates to the quality of the operation by which the result is obtained.

Advection--Transport of water or an aqueous property solely by mass motion.

Aging Waste Tank--A tank that stores neutralized current acid waste generated from the PUREX Plant.

Analyte--The element, ion, or compound of interest.

ANOVA (analysis of variance)--Name given to a variety of statistics procedures. All of these procedures compare the means of different groups of observations to determine whether there are any significant differences among the groups. 
Anticlinal--Pertaining to an anticline.

Anticline--A fold, generally convex upward, whose core contains the stratigraphically older rocks.

Aquifer--A geologic formation, group of formations, or part of a formation capable of yielding a significant amount of ground water to wells or springs.

Aquitard--A confining bed that retards but does not prevent the flow of water to or from an adjacent aquifer.

Assessment-level monitoring--A program of monitoring groundwater under interim status requirements. After a release of contaminants to groundwater has been determined, the rate of migration, extent of contamination, and dangerous constituent concentration gradients of the contamination must be identified.

Background--The composition of a medium that has not been affected by activities at a waste management unit.

Bar--A mass of sand, gravel, or alluvium deposited on the bed of a stream, sea, or lake or at the mouth of a stream forming an obstruction to water navigation.

Basalt--A dark- to medium-dark-colored mafic (iron-magnesium rich) extrusive igneous rock with small grains composed primarily of feldspar (calcic plagioclase), pyroxene, with or without olivine, and varying proportions of glass.

Borehole Compilation Data Package Report--A document that summarizes all activities at a wellsite during a calendar year, based on a compilation of validated records. This document also includes an interpretation of hydrologic data used to support characterization and permitting activities for the RCRA TSD units.

Bottom zones--Refers to the base of basalt flows where aquifers can be found.

By-product material--A material that is not one of the primary products of a production process and is not solely or separately produced by the production process. Examples are process residues such as slags or distillation column bottoms. The term does not include a co-product that is produced for the general public's use and is ordinarily used in the form it is produced by the process (WAC 173-303-040).

"(a) For purposes of this part, the term "byproduct material" means any radioactive material (except special nuclear material) yielded in or made radioactive by exposure to the radiation incident to the process of producing or utilizing special nuclear material.

(b) for purposes of determining the applicability of the Resource Conservation and Recovery Act (42 U.S.C. 6901 et seq.) to any radioactive waste substance owned or produced by the Department of Energy pursuant to the exercise of its atomic energy research, development, testing and production responsibilities under the Atomic Energy Act of 1954 (42 U.S.C. 2011 et seq.), the words "any radioactive material," as used in paragraph (a) of this section, refer only to the actual radionuclides dispersed or suspended in the waste substance. The nonradioactive hazardous component of the waste substance will be subject to regulation under the Resource Conservation and Recovery Act." (10 CFR 962.3)

Carbonate--A compound containing the radical carbonate. 
1 Cataclysmic--Any geologic event that produces sudden and extensive changes in the Earth's surface.

CERCLA past-practice unit--A process by which a past-practice unit containing hazardous substances is addressed for remedial action (as opposed to RCRA past-practice).

CERCLA remedial investigation--The CERCLA process of determining the extent of hazardous waste contamination; analogous to the RCRA facility investigation.

Channelways--Ancient or recent streams or river beds including flood zones.

Cobble--A rock fragment that ranges from 64 to 256 millimeters in diameter.

Compliance--Not exceeding regulations.

Confined aquifer--Groundwater bounded above and below by impermeable layers.

Conglomerate--.Rounded water worn fragments of rock or pebbles, cemented together by another mineral substance.

Conservative tracer--A tracer that does not chemically interact or degrade the aquifer system (i.e., the total quantity of the material in the solution remains constant).

Contaminant mobility--The capability of any physical, chemical, or biological substance having an adverse effect on air, water, or soil and that can be transported readily by wind or water.

Control chart--Area graphical presentations of analytical data to determine if results are within desired limits.

Corrective measures study--The step in the RCRA past-practice process in which alternatives for a corrective action system are investigated and screened; comparable to the feasibility study phase of the CERCLA process.

Criteria pollutants- (40 CFR, Part 58, Appendix G) means the pollutant or pollutant combination (TSP $\mathrm{x}$ $\mathrm{SO}_{2}$ ) with the highest subindex during the reporting period.

Critical systems--Those specific portions of a TSD unit's structure or equipment whose failure could lead to the release of dangerous waste into the environment and/or systems, which include processes that treat, transfer, store or dispose of regulated waste. A list identifying the critical systems of a specific TSD unit may be developed and included in Part III or Part V of the HF RCRA Permit. In developing a critical system list, or in the absence of a critical system list, WAC 173-303-830 modifications will be considered.

Cross-section--A profile or portraying of an interpretation of a vertical section of the Earth explored by geophysical and or geological methods.

Dangerous wastes--As defined in the HF RCRA Permit, means those solid wastes designated under 46 WAC 173-303 as dangerous or extremely hazardous waste. As used in the Permit, the words "dangerous

47. waste" will refer to the full universe of wastes regulated by Chapter 70.105 RCW and WAC 173-303 
1 (including dangerous waste, hazardous waste, extremely hazardous waste, mixed waste, and acutely

2 hazardous waste).

Derived concentration guidelines--A calculated concentration that would result in an annual dose of 100 millirem.

Detection--The lowest concentration by which an analyte can be detected on a field or laboratory instrument. Often recorded in parts per million or parts per billion.

Detrital--Pertaining to or formed by detritus material.

Detritus--A collective term used for loose rock and mineral material that is worn away by mechanical means, as by disintegration or abrasion (e.g., sand, silt, and clay).

Diffusion--The actual transport of mass, in the form of discrete atoms, through the lattice of a crystalline solid.

Discharge--The rate of flow at any given moment, expressed in volume per unit time (e.g., cubic meters/second).

"Dangerous waste discharge" means the accidental or intentional release of hazardous substances, dangerous waste, or dangerous waste constituents such that the substance, waste, or a waste constituent may enter or be emitted into the environment (WAC 173-303-040).

Dispersivity--Ability of a contaminant to disperse within the groundwater by molecular diffusion and chemical mixing.

Distribution coefficient--The ratio of the concentration of a solute sorbed by ion exchange substances such as Earth materials, particularly clays, to the concentration of the solute remaining in solution. A large distribution coefficient implies that the substance is readily sorbed and is redissolved slowly. The concentration of material in the solid phase (i.e., rock or sediment) (moles per gram) divided by the concentration of material in the aqueous phase (moles per liter).

Domenico-Robbins--A two dimensional analytical transport model developed by Domenico and Robbins (1985).

Drinking Water Standard--Contaminant concentration specified in the Safe Drinking Water Act.

Drive-barrel--Heavy-walled pipe used in impact drilling. Soil and rock are driven into a pipe connected to a cable as it is dropped rapidly on to the ground. The soil or rock is extracted by striking the pipe.

Driving force--The hydraulic head that causes water to flow in one direction or another.

Duplicate blank--A sample retrieved from a single sampling location using the same equipment and sampling technique but analyzed independently.

Effective porosity--The ratio of the volume of the void spaces of a soil mass that can be drained by gravity to the total volume of the mass of the soil. 
1 Eolian--(a) Pertaining to the wind; especially said of such deposits as loess and dune sand, of sedimentary 2 structures such as wind-formed ripple marks, or of erosion and deposition accomplished by the wind. (b) 3 Said of the active phase of a dune cycle, marked by diminished vegetal control and increased dune growth.

Epiclastic--A term applied to mechanically deposited sediments (e.g., mud, gravel, sand) consisting of weathered products of older rocks. A rock formed at the Earth's surface by consolidation of fragments of preexisting rocks.

Epoch--A division of geologic time that identifies an abrupt change in the environment.

Equipment blanks--Prepared before sampling by running deionized water over sampling equipment and collecting the water in a clean sample container. If the equipment blank is found to be contaminated, the source of contamination is assumed to be the equipment used during the sampling event.

Erosional windows--Portions of the land surface that have been eroded away exposing landforms that represent the past.

Evapotranspiration--The sum total of that portion of precipitation that is returned to the atmosphere through evaporation and the transpiration of plants.

Extremely hazardous waste--Those dangerous and mixed wastes designated in WAC $173-303-100$ as extremely hazardous.

Facies--Part of a rock body as differentiated from other parts by appearance or composition and that reflects the environment in which it was formed.

Facility--As defined in WAC 173-303-040 means all contiguous land, and structures, other appurtenances, and improvements on the land used for recycling, reusing, reclaiming, transferring, storing, treating, or disposing of dangerous waste. A facility may consist of several treatment, storage, or disposal operational units (e.g., one or more landfills, surface impoundments, or combination of them). Unless otherwise specified, the terms "facility," "treatment, storage, and/or disposal facility," "TSD facility," "dangerous waste facility" or "waste management facility" are used interchangeably. For the purposes of implementing corrective action imposed pursuant to WAC 173-303-646 (2) or (3), the term facility has the following meaning: All contiguous property under the control of an owner or operator seeking or required to have a permit under the provisions of Chapter $70.105 \mathrm{RCW}$ or WAC 173-303, including the definition of facility at RCW 70.105D.020(3).

As defined in the HF RCRA Permit, means all contiguous land, and structures, other appurtenances, and improvements on the land used for recycling, reusing, reclaiming, transferring, storing, treating, or disposing of dangerous waste.

Depending on context, 'facility' could refer to:

- The Hanford Facility

- Building nomenclature commonly used on the Hanford Facility. In this context, the term 'facility' remains as part of the title for various TSD units (e.g., 616 Nonradioactive Dangerous Waste Storage Facility) 
- For purposes of complying with the RCRA corrective action provisions, all contiguous property under the control of the owner or operator seeking a permit under Subtitle C of RCRA.

Fanglomerate--A fanglomerate is composed of heterogenous material that was originally deposited in an alluvial fan or delta as loose unconsolidated detrital material and has since become cemented into rock.

Feasibility study--The step in the CERCLA process in which altematives for a remedial action system are investigated and screened.

Field duplicates--Independent samples that are taken from the same location at the same time and are used to measure the representativeness of the sampling event. This is a measure that describes both the variability of waste composition and variability of the sampling technique.

Fixed limits--A constant compliance limit or a fixed standard such as maximum concentration limit or assessment level monitoring.

Flow tops--Pertaining to the highest portion of individual basalt flows.

Fluvial-lacustrine--Said of those deposits formed by the streams flowing from lakes.

Formation(s)--Something naturally formed, commonly differing from adjacent rocks or soils. Most formations possess certain distinctive or repetitive combinations of distinctive rock types.

Geophysical--Pertaining to that science that deals with the exploration or prospecting of the Earth using instruments and applying the methods of physics and engineering by observation of magnetic, seismic, electrical, and thermal distribution.

Glaciofluvial--Pertaining to streams flowing from glaciers or to the deposits made from these streams. In the Hanford Site area, this pertains to the deposited sands and gravels that were deposited because of the Lake Missoula flood.

Grab sample--A single sample that is collected at a time and place most representative of total discharge.

Granule--A rock fragment larger than a very coarse sand grain and smaller than a pebble. The fragment ranges in size from 2 to 4 millimeters.

Gravels--An accumulation of water worn pebbles. Consists of rock grains or fragments that range in size from 4.76 to 76 millimeters.

Groundwater mounds--A mound shaped elevation in a water table that builds up as a result of the downward percolation of water through the zone of aeration.

Hard-tool--Drill bit used in cable tool drilling to crush rock. The slurry created by the bit is retrieved and examined.

Hazardous waste--Those solid waste designated by 40 CFR 261, and regulated as hazardous and/or mixed waste by the EPA. 
1 Henry's Law--The weight of a gas dissolved by a liquid is proportional to the pressure of the gas.

High energy--Refers to the environment of sediment deposition where the stream or river flow or wave action is of sufficient quantity to carry significant amounts of suspended soil and rock particles.

High-activity waste--High- and low-activity is reflective of the relative concentration of radionuclides in mixed waste.

High-level waste--Highly radioactive waste material that results from the reprocessing of spent nuclear fuel, including liquid waste produced directly in reprocessing and any solid waste derived from the liquid that contains a combination of transuranic waste and fission products in concentrations requiring permanent isolation.

Holocene--Recent. That period in time (epoch) since the last ice age in North America; also those sediments deposited during that epoch.

Hydraulic head--The height of the free surface of a body of water above a given subsurface point.

Hydraulic conductivity--The ratio of the groundwater flow velocity to the driving force for fluid flow through porous medium under saturated conditions.

Hydraulic gradient--As applied to an aquifer, the rate of change of the hydraulic head per unit of distance at a given point and direction.

Hydrogeology--A term used interchangeably with geohydrology referring to the hydrologic or flow characteristics of groundwater.

Hydrologic properties--Properties of a rock related to the capacity to transmit, hold, and deliver water.

Immiscible--Cannot be mixed (fluids).

Indicator-A geologic or other feature that suggests the presence of a geochemical anomaly inherent to the local geologic setting.

Indurated--The consolidation of a rock or soil hardened by heat, pressure, or cementation.

Infiltration--The flow of fluid (water) into a solid substance through pores or small openings.

Intercalated--Said of a relatively thin layer of soil or rock material that alternates with thicker layers of some other kind of soil or rock.

Intermittent--Periodic. Stopping and starting again in intervals.

Interval--The vertical difference between soil or rock bodies of differing origin or composition.

Limit of Quantitation--The level above which quantitative analysis can be obtained with a specific degree of confidence (generally the mean background signal plus 10 standard deviations). 
1 Loess--A homogeneous, nonstratified (nonlayered) unindurated soil consisting predominantly of silt of eolian 2 (windblown) deposition. Often referred to as 'Palouse soil' located in the far central southeastern portion of 3 Washington state.

Low-activity waste--Refer to high-activity waste.

Low-level waste--Waste that contains radioactivity and is not classified as high-level waste, transuranic waste, or spent nuclear fuel or 11 e(2) by-product material as defined in U.S. Department of Energy Order 5820.2A. Test specimens of fissionable material irradiated for research and development only, and not for the production of power or plutonium, may be classified as low-level waste, provided the concentration of transuranic is less than 100 nanocuries per gram.

Maximum concentration limit--Contaminant concentration specified in the Safe Drinking Water Act.

Miocene--The fourth of the five epochs of which the Tertiary period is divided. The Miocene lasted from between 24 million years ago to 1.8 million years ago. Also those sediments that were deposited during that epoch.

Miscellaneous TSD unit--As defined in WAC 173-303-040, means a dangerous waste management unit where dangerous waste is treated, stored, or disposed of and that is not a container, tank, surface impoundment, pile, land treatment unit, landfill, incinerator, boiler, industrial furnace, containment building, corrective action management unit, temporary unit, underground injection well with appropriate technical standards under 40 CFR Part 146, or unit eligible for a research, development, and demonstration permit under WAC 173-303-809.

Miscellaneous waste management unit--One-time spills to the environment and sanitary waste disposal facilities.

Mixed waste--As defined in WAC 173-303-040, means a dangerous, extremely hazardous, or acutely hazardous waste that contains both a nonradioactive hazardous component and, as defined by $10 \mathrm{CFR}$ 20.1003, source, special nuclear, or by-product material subject to the Atomic Energy Act.

Model--A working hypothesis or precise simulation, by means of description, statistical data, or analogy of a phenomenon or process that cannot be observed directly or that is difficult to observe directly.

Monocline--A steplike bend (flexure) in otherwise flatlying layers or beds of rock.

Operable unit--A group of contiguous past-practice waste sites related by site characteristics or operations so as to be considered collectively for purposes of environmental restoration under the CERCLA process.

Operating unit--A TSD unit that has been, or is anticipated to be, included in Part III of the HF RCRA Permit.

Oral reference dose--Defined as the level of daily human exposure at or below which no adverse effect is expected to occur during a lifetime.

Overbank deposits--Sediments (usually silt and clay) deposited beyond the natural levee of a stream or river during a flooding event. 
Paleosols--A buried soil of the ancient past.

Palouse soil--Refer to loess.

Parameter--In statistics, a numerical quantity (such as the mean) that characterizes the distribution of a random variable or a population.

Permeability--The property or capacity of a porous rock, sediment, or soil for transmitting a fluid (e.g., groundwater).

Permeameter--An instrument for measuring permeability.

Perennial--Streams that flow throughout the year from source to mouth.

Physiography--The study of the genesis and evolution of land forms.

Pleistocene--The earliest of the two epochs comprising the Quatemary period. The Pleistocene lasted from between 1.8 million years ago to 10,000 years ago. Also, those sediments that were deposited during that epoch.

Porosity--The percentage of the bulk volume of a rock or soil that is occupied by interstices or voids.

Potentiometric--Surface to which water in an aquifer would rise by hydrostatic pressure or head.

Practical quantification limits--The lowest level that can be reliably achieved within specified limits of precision and accuracy during routine laboratory operating conditions.

Pre-Missoula--As pertaining to before the time of the flooding caused by the breaching of ice dams that contained Lake Missoula in northwest Montana.

Precision--The degree of agreement or uniformity of repeated measurements of a quantity; the degree of refinement. Refer to accuracy.

Prediction interval--In a regression analysis, a value or set of values for which one can assert with given probability that the value will contain a future observation.

Privatization--Refers to vendors, under contract with the U.S. Department of Energy, using private funding to design, permit, construct, operate, and deactivate their own equipment and facilities to treat tank waste.

Purgewater--Water being excavated from wells or from.wells that are undergoing aquifer testing.

Quartzose--Containing quartz as the principal constituent.

RCRA facility investigation--The RCRA process of determining the extent of hazardous waste contamination; analogous to the CERCLA remedial investigation.

Recharging--The quantity of water that is added to the zone of saturation or the aquifer. Intake. 
Recovery phase--The time an aquifer requires to reach equilibrium after pumping, such as in a slug test.

Sand--Detrital material varying in diameter from very fine grained $(0.0625$ to 0.125 millimeter $)$ to very coarse grained ( 2 millimeter).

Sandy--A rock or soil in which one of the constituents is sand. Refer to sand.

Sediment--(a) (geological) Solid fragmental material that originates from weathering of rocks and is transported by air, water, or ice, or that accumulates by other natural agents, such as chemical precipitation from solution or secretion by organisms; and that forms in layers on the Earth's surfaces at ordinary temperatures in a loose unconsolidated form; e.g., sand, gravel, silt, mud, till, loess, alluvium. (b) Strictly solid material that has settled from a state of suspension in a liquid, e.g., material at the bottom of an open body of water, such as a pond or an estuary. In the singular, the term usually is applied to material held in suspension in water or recently deposited from suspension. In the plural, the term is applied to all kinds of deposits, and refers to essentially unconsolidated materials.

\section{Seismic--Pertaining to an earthquake or earth vibration.}

Semi-confined aquifer-A partially isolated aquifer. Refer to definition of aquifer.

Significant discrepancy--In regard to a manifest or shipping paper means a discrepancy between the quantity or type of dangerous waste designated on the manifest or shipping paper and the quantity or type of dangerous waste a TSD unit actually receives. A significant discrepancy in quantity is a variation greater than 10 percent in weight for bulk quantities (e.g., tanker trucks, railroad tank cars, etc.), or any variation in piece count for nonbulk quantities (i.e., any missing container or package would be a significant discrepancy). A significant discrepancy in type is an obvious physical or chemical difference that can be discovered by inspection or waste analysis (e.g., waste solvent substituted for waste acid).

Silt-A soil particle that ranges in size from 0.0039 to 0.0625 millimeter in diameter.

Silty--A rock or soil in which one of the constituents is silt. Refer to silt.

Slope wash--Soil and rock material that is being or has been moved down slope predominantly by the action of gravity assisted by running water that is not concentrated into channels.

Slope--The inclined surface of hill, mountain, plateau, plain, or any other part of the Earth's surface.

Slug testing--A single well test to determine the insitu hydraulic conductivity of an aquifer by the instantaneous addition or removal of a known quantity (slug) of water into or from a well, and the subsequent measurement of the resulting well recovery time.

Solid waste management unit--Any discemible location at a facility, defined for the purposes of corrective action, where solid waste has been placed at any time, irrespective of whether the location was intended for the management of solid or dangerous waste. Such locations include any area at a facility at which solid waste, including spills, routinely and systematically have been released. Such units include regulated units as defined by WAC 173-303. 
1 Source material--"(1) uranium, thorium, or any other material which is determined by the Commission 2 pursuant to the provisions of Section 61 [42 U.S.C. 2091] to be source material; or (2) ores containing one or 3 more of the foregoing materials, in such concentration as the Commission may by regulation determine from 4 time to time." (Atomic Energy Act)

Special nuclear material--"(1) plutonium, uranium enriched in the isotope 233 or in the isotope 235 , and any other material which the Commission, pursuant to the provisions of Section 51 [42 U.S.C. 2071], determines to be special nuclear material, but does not include source material; or (2) any material artificially enriched by any of the foregoing, but does not include source material." (Atomic Energy Act)

Specific conductance--A measure of the electrical conductivity of a liquid.

Split-spoon sampler--A device used to sample below the surface through the vadose zone. Samples are obtained using a split barrel that is lined with ring or tube liners.

Stratigraphic--Said of a stratum by which an arbitrary but systematic arrangement, zonation, or partitioning of a sequence of rock layers, of the Earth's crust, into units with reference to any or all of the attributes, properties, or characteristics that strata possess.

Structural--Pertaining to, part of, or consequent upon geologic structures.

Structures (tectonic)--Of, pertaining to, or designating rock structure and deformations as a result of forces caused by land movement and earthquakes.

Suprabasalt--Those sediments that are found above basalt flows.

Syncline--A fold, generally upward concaving, whose core contains the stratigraphically youngest rock.

Temperature--Degree of hotness or coldness of a body or environment.

Tolerance--A permissible deviation from a specified value, expressed in actual values or more often as a percentage of the nominal value.

Topography--The general configuration of a land surface or any part of the Earth's surface, including its relief and its natural and man made features.

Transmissive zone--Pertaining to transmissivity. The zone where intercommunication is possible between differing aquifers.

Transmissivity--The rate (flow) at which water is transmitted through a unit width of aquifer.

Transuranic waste--Without regard to source or form, waste that is contaminated with alpha-emitting transuranium radionuclides with half-lives greater than 20 years and concentrations greater than 100 and radium sources.

Travel time--The period of time necessary for a dangerous waste constituent released to the soil to enter any 
1 Trip blanks--Sample containers that are prepared with deionized water and are carried into and out of the 2 field but are not opened at any time during the sampling event. If the trip blank is found to be contaminated, 3 the source of the contamination is assumed to be the container itself, the environment in which the trip blank 4 was prepared, or another source outside the sample area.

Tuff--A general term for all consolidated volcanic fragments.

Turbidity--The state, condition, or quality of opaqueness or reduced clarity of a fluid, due to the presence of suspended matter.

Unit dispositioned through other options--A TSD unit that is not categorized as either an 'operating unit' or a 'unit undergoing closure'.

Unit undergoing closure--A TSD unit that has been, or is anticipated to be, included in Part V of the HF RCRA Permit.

Vadose zone--Zone of acration. A subsurface zone containing water under pressure less than that of the atmosphere, including water held by capillarity; and containing air or gases generally under atmospheric pressure. This zone is limited above by the land surface and below by the surface of the 'zone of saturation', i.e., the water table.

Vapor pressure--The pressure at which a liquid and its vapor are at equilibrium at a given temperature.

Velocity--The rate of motion in a given direction (meter/second).

Veneer--A thin but extensive layer of sediments covering an older geologic layer or stratum.

Volcanic--Of, pertaining to, like, or characterized by or composed of material originating from volcanoes or fissures.

Volcaniclastic--Pertaining to clastic or fragmental rock material containing volcanic material in whatever proportion, and without regard to its origin or environment.

Waste management unit--Means an individual location on the Hanford Site where waste has or may have been placed, either planned or unplanned, as identified in the Tri-Party Agreement. Includes: (1) RCRA disposal units, (2) CERCLA disposal units, (3) unplanned releases, (4) inactive contaminated structures, (5) RCRA TSD units, and (6) other storage areas. Because of the comprehensive nature of the Units Report (DOE/RL-88-30), the list of units is more extensive than required by Section 3004(u) of HSWA.

Water table--The upper surface of a saturation zone except where that surface is formed by an impermeable layer.

Yakima Fold Belt--Characterized by long, narrow anticlines and broad synclines extending generally eastward from the Cascade Range to the approximate center of the Columbia Plateau. 
1 Key Sources (in addition to cited regulations):

2

Bates, R.L., 1990, "Glossary of Geology", J.A. Jackson, ed., American Geological Institute, Falls Church, Virginia.

Basalt Waste Isolation Project Glossary, SD-BWI-PMP-005, Rockwell Hanford Operations, Richland, Washington.

Dictionary of Geological Terms, Anchor Books Edition: 1976, Anchor Press/Doubleday, Garden City, New York.

A Dictionary of Mining, Mineral and Related Terms, 1968, U.S. Department of the Interior, U.S. Printing Office, Washington D.C.

Ecology, EPA, and DOE, 1996, Hanford Federal Facility Agreement and Consent Order, as amended, Washington State Department of Ecology, U.S. Environmental Protection Agency, U.S. Department of Energy, Olympia, Washington.

The Environmental Dictionary, compiled by J. J. King, Executive Enterprises Publications. Co., Inc., New York, New York, 1993.

EPA, 1989, Statistical Analysis of Ground-Water Monitoring Data at RCRA Facilities, Interim Final Guidance, PB89-15047, U.S. Environmental Protection Agency, Washington, D.C.

Freeze, R.A. and J.A. Cherry, 1979, Groundwater, Prentice-Hill Inc., Englewood Cliffs, New Jersey.

King, J.J., 1989, The Environmental Dictionary, Executive Enterprises, New York, New York.

Lee, C.C., 1989, Environmental Engineering Dictionary, Government Institutes Inc., Rockville, Maryland.

RCRA Groundwater Monitoring Technical Enforcement Guidance Document, 1986, National Water Well Association, Dublin, Ohio.

Myers, C.W.S.M. Price, and J.A. Caggiano, M.P. Cochran, W.J. Czimer, N.J. Davidson, R.C. Edwards, K.R. Fecht, G.E. Holmes, M.G. Jones, J.R. Kunk, R.D. Landon, R.K. Ledgerwood, J.T. Lillie, P.E. Long, T.H. Mitchell, E.H. Price, S.P. Reidel, and A.M. Tallman, 1979, Geologic Studies of the Columbia Plateau, A Status Report, RHO-BWI-ST-4, Rockwell Hanford Operations, Richland, Washington.

Webster's New Riverside University Dictionary, 1984, Houghton Mifflin Company, Boston, MA. 


\section{METRIC CONVERSION CHART}

Into metric units

\begin{tabular}{|c|c|c|c|c|c|}
\hline If you know & Multiply by & To get & If you know & Multiply by & To get \\
\hline \multicolumn{3}{|c|}{ Length } & \multicolumn{3}{|c|}{ Length } \\
\hline inches & 25.40 & millimeters & millimeters & 0.0393 & inches \\
\hline inches & 2.54 & centimeters & centimeters & 0.393 & inches \\
\hline feet & 0.3048 & meters & meters & 3.2808 & feet \\
\hline yards & 0.914 & meters & meters & 1.09 & yards \\
\hline miles & 1.609 & kilometers & kilometers & 0.62 & miles \\
\hline \multicolumn{3}{|c|}{ Area } & \multicolumn{3}{|c|}{ Area } \\
\hline square inches & 6.4516 & $\begin{array}{l}\text { square } \\
\text { centimeters }\end{array}$ & $\begin{array}{l}\text { square } \\
\text { centimeters }\end{array}$ & 0.155 & square inches \\
\hline square feet & 0.092 & square meters & square meters & 10.7639 & square feet \\
\hline square yards & 0.836 & square meters & square meters & 1.20 & square yards \\
\hline square miles & 2.59 & $\begin{array}{l}\text { square } \\
\text { kilometers }\end{array}$ & $\begin{array}{l}\text { square } \\
\text { kilometers }\end{array}$ & 0.39 & square miles \\
\hline acres & 0.404 & hectares & hectares & 2.471 & acres \\
\hline \multicolumn{3}{|c|}{ Mass (weight) } & \multicolumn{3}{|c|}{ Mass (weight) } \\
\hline ounces & 28.35 & grams & grams & 0.0352 & ounces \\
\hline pounds & 0.453 & kilograms & kilograms & 2.2046 & pounds \\
\hline short ton & 0.907 & metric ton & metric ton & 1.10 & short ton \\
\hline \multicolumn{3}{|c|}{ Volume } & \multicolumn{3}{|c|}{ Volume } \\
\hline fluid ounces & 29.57 & milliliters & milliliters & 0.03 & fluid ounces \\
\hline quarts & 0.95 & liters & liters & 1.057 & quarts \\
\hline gallons & 3.79 & liters & liters & 0.26 & gallons \\
\hline cubic feet & 0.03 & cubic meters & cubic meters & 35.3147 & cubic feet \\
\hline cubic yards & 0.76456 & cubic meters & cubic meters & 1.308 & cubic yards \\
\hline \multicolumn{3}{|c|}{ Temperature } & \multicolumn{3}{|c|}{ Temperature } \\
\hline Fahrenheit & $\begin{array}{l}\text { subtract } 32 \\
\text { then multiply } \\
\text { by } 5 / 9 \text { ths }\end{array}$ & Celsius & Celsius & $\begin{array}{l}\text { multiply by } \\
9 / 5 \text { ths, then } \\
\text { add } 32\end{array}$ & Fahrenheit \\
\hline \multicolumn{3}{|c|}{ Force } & \multicolumn{3}{|c|}{ Force } \\
\hline $\begin{array}{l}\text { pounds per } \\
\text { square inch }\end{array}$ & 6.895 & kilopascals & kilopascals & $1.4504 \times 10^{-4}$ & $\begin{array}{l}\text { pounds per } \\
\text { square inch }\end{array}$ \\
\hline
\end{tabular}

\section{Source: Engineering_Unit Conversions, M. R. Lindeburg, PE., Second Ed., 1990, Professional}

Publications, Inc., Belmont, California. 
DOE/RL-91-28, Rev. 4

$05 / 98$

This page intentionally left blank. 
DOE/RL-91-28, Rev. 4

$05 / 98$

\section{APPENDIX 2C}

HANFORD FACILITY LEGAL DESCRIPTION 
This page intentionally left blank. 


\section{HANFORD FACILITY LEGAL DESCRIPTION}

The following legal description describes the overall facility boundaries of the DOE-RL controlled Hanford Site. Individual TSD units use only a very small portion of the Hanford Site. Additional descriptive information on the individual TSD units is contained in the Unit-Specific Portion of this permit application:

The Hanford Site being a tract of land located in Benton County, WA, the aforesaid tract being more particularly described as follows:

Commencing at the point of intersection of the E.-W. centerline of sec. 14, T.10N., R.28E. Willamette Meridian, with the western navigation line of the Columbia River;

Thence northerly 200 feet along said line of navigation to the TRUE POINT OF BEGINNING;

Thence W. to a point on the W. right-of-way line of George Washington Way, which line is the boundary of the city of Richland;

Thence southerly 100 feet or less, along said right-of-way line of George Washington Way to a point on the N. right-of-way line of Horn Rapids Road, an unplatted road;

Thence W. along the N. right-of-way line of Horn Rapids Road approximately $1 / 2$ mile to the E. rightof-way line of Stevens Drive, an unplatted road;

Thence continuing westerly and northwesterly along the N. right-of-way line of Horn Rapids Road 28,600 feet more or less to the line's intersection with the N. right-of-way line of State Highway 240, in the N.E. $1 / 4$ of sec. 11, T.10N., R.27E.W.M.;

Thence northwesterly along said $\mathrm{N}$. right-of-way line of the highway, 75 feet $\mathrm{N}$. of and parallel with the centerline of said highway to a point in sec. 3, T.10N., R.27E.W.M., which point is on the eastward extension of the N. right-of-way line of a county road from Horn Rapids to Benton City;

Thence along the northerly and westerly right-of-way line of said road, 75 feet northerly and westerly of, and parallel with, the center line of said road to a point on the E. line of sec. 8, T.10N., R.27E.W.M.;

Thence $\mathrm{N}$. to the $\mathrm{E}$. quarter comer of said section;

Thence W. to the S.W. corner of the E. $1 / 2$ of the N.E. $1 / 4$ of sec. 12, T.10N., R.26E.W.M.;

Thence $\mathrm{N}$. to the $\mathrm{N}$. line of said sec. 12;

Thence W. to the N.E. comer of the N.W. $1 / 4$ of the N.W. $1 / 4$ of the N.W. $1 / 4$ of sec. 11, T.10N., R.26E.W.M.;

Thence S. 660 feet;

Thence W. 660 feet to the E. line of sec. 10, T.10N., R.26E.W.M.;

Thence S. to the S.E. quarter corner of said sec. 10;

Thence W. along the E.W.W. centerline of sec. 10 to the W. line of said section;

Thence N. along the W. section line to the S.E. corner of sec. 4, T.10N., R.26E.W.M.;

Thence W. along the S. line of sec. 4 and sec. 5 to the S.W. comer of the S.E. 1/4 of the S.E. 1/4 of sec. 5;

Thence N. to the S.E. corner of the N.W. $1 / 4$ of the S.E. $1 / 4$ of sec. 5 ;

Thence W. along the S. line of the N.W. $1 / 4$ of the S.E. 1/4 to the S.W. corner of the N.W. $1 / 4$ of the S.E. $1 / 4$

Thence N. to the S.E. corner of the N. $1 / 2$ of the N.W. $1 / 4$;

Thence W. along the S. line of the N. $1 / 2$ of the N.W. $1 / 4$ to the W. line of sec. 5;

Thence N. to the S.E. comer of sec. 31, T.11N., R.26E.W.M.;

Thence W. along the S. line of the E. $1 / 2$ of the S.E. $1 / 4$ of sec. 31 to the E. line of said E. $1 / 2$ of the S.E. $1 / 4$ of sec. 31; 


\section{HANFORD FACILITY LEGAL DESCRIPTION (cont)}

Thence N. along the W. line of the E. $1 / 2$ of the S.E. $1 / 4$ to the S.E. comer of the S.W. $1 / 4$ of the N.E. $1 / 4$ of sec. 31 N.E. $1 / 4$;

Thence W. along the S. line of the S.W. $1 / 4$ of the N.E. $1 / 4$ to the S.W. corner of the S.W. $1 / 4$ of the

Thence N. along the W. line of the S.W. $1 / 4$ of the N.E. $1 / 4$ to the S.E. corner of the N. $1 / 2$ of the N.W. $1 / 4$ of said sec. 31 ;

Thence W. along the S. line of the N. $1 / 2$ of the N.W. $1 / 4$ to the W. line of said sec. 31;

Thence N. along the W. line of sec. 31 to the S.E. corner of sec. 25, T.11N., R.25E.W.M.;

Thence W. along the S. line of sec. 25 to the S.W. corner of the S.E. 1/4 of the S.E. 1/4 of said sec. 25;

Thence N. along the W. line of the S.E. $1 / 4$ of the S.E. $1 / 4$ to the S.E. corner of the N.W. 1/4 of the S.E. 1/4;

Thence W. along the S. line of the N.W. $1 / 4$ of the S.E. $1 / 4$ to the S.W. corner of the N.W. $1 / 4$ of the S.E. 1/4;

Thence N. along the W. line of the N.W. $1 / 4$ of the S.E. $1 / 4$ to the S.E. comer of the N.W. $1 / 4$ of sec. 25

Thence W. along the S. line of the N.W. $1 / 4$ of sec. 25 to the W. line of $\sec 25$;

Thence N. along the W. line of sec. 25 and the W. line of sec. 24 to the N. line of the S. $1 / 2$ of the S. $1 / 2$ of sec. 23;

Thence W. along the N. line of the S. $1 / 2$ of the S. $1 / 2$ of sec. 23 and the N. line of the $S .1 / 2$ of the $S .1 / 2$ of sec. 22 and the N. line of the S. $1 / 2$ of the S. $1 / 2$ of sec. 21 to the E. line of sec. 20 ;

Thence S. to the S.E. corner of sec. 20 ;

Thence W. along the S. line of sec. 20 and the S. line of sec. 19 to the S.E. corner of the S.W. $1 / 4$ of the S.W. $1 / 4$ of sec. 19 ;

Thence N. to the N.E. comer of the S.W. 1/4 of the S.W. $1 / 4$ of sec. 19;

Thence W. to the W. line of sec. 19, all being in T.11N., R.25E.W.M.;

Thence continuing W. to the S.W. corner of the N.E. $1 / 4$ of the S.E. $1 / 4$ of sec. 24, T.11N.,

\section{R.24E.W.M.;}

Thence N. to the N.W. corner of said N.E. $1 / 4$ of the S.E. $1 / 4$ of sec. 24 ;

Thence W. to the S.W. comer of the S.E. $1 / 4$ of the N.W. $1 / 4$ of sec. 24;

Thence N. to the N.W. corner of said S.E. $1 / 4$ of the N.W. $1 / 4$ of sec. 24;

Thence W. to the W. line of sec. 24;

Thence N. to the N.W. corner of sec. 24;

Thence W. to the S.E. quarter corner of sec. 14;

Thence N. to the N.W. quarter corner of sec. 14;

Thence $W$. along the N. line of sec. 14 to the N.W. corner of sec. 14;

Thence N. along the W. line of sec. 11 and sec. 2 to the N.W. comer of sec. 2 , all being in T.11N., R.24E.W.M., and continuing N. along the W. lines of secs., 35, 26, 23, 14, 11, and 2, all being in T.12N., R.24E.W.M.;

Thence continuing $N$. along the W. lines of secs. 35 and 26 in T.13N., R.24E.W.M., to the N.W. corner of sec. 26;

- Thence W. along the S. line of sec. 22 to the S.E. quarter corner of sec. 22;

Thence N: along the N..S. centerline of sec. 22 to the N.E. quarter corner of sec. 22;

Thence W. along the S. line of sec. 15 to the S.W. corner of sec. 15 ;

Thence N. along the W. line of sec. 15 to the S.W. comer of the N. $1 / 2$ of the N.W. $1 / 4$ of sec. 15 ; 


\section{HANFORD FACILITY LEGAL DESCRIPTION (cont)}

Thence E. along the S. line of the N. $1 / 2$ of the N.W. $1 / 4$ of sec. 15 to the S.W. corrier of the N.W. 1/4 of the N.E. $1 / 4$ of sec. 15 ;

Thence N. along the W. line of the S.W. $1 / 4$ of the N.E. $1 / 4$ of sec. 15 and continuing N. along the centerline of sec. 10 to the W. navigation line of the Columbia River, following said navigation line easterly, northerly, and southerly to a point directly W. of the S. line of Tract 4 of Ringold Tracts according to the plat filed in the records of Franklin County.

Thence southerly along the said W. line of navigation to the TRUE POINT OF BEGINNING.

Also included is a parcel of land (for Environmental and Molecular Sciences Laboratory) situated in the S.W. 1/4 of sec. 14, T.10N., R.28E.W.M., Benton County, Washington, described as follows: beginning at the S.E. comer of said S.W. 1/4; thence N $01^{\circ} 45^{\prime} 22^{\prime \prime}$ W along the E line of said S.W. $1 / 4$ a distance of 2640.77 feet to the N.E. corner of said S.W. 1/4; thence $S 89^{\circ} 31^{\prime} 50^{\prime \prime} \mathrm{W}$ along the N line of said S.W. $1 / 4$ a distance of 961.53 feet; thence $S 00^{\circ} 55^{\prime} 00^{\prime \prime} \mathrm{E}$ a distance of 47.10 feet to the $S$ margin of Hom Rapids Road and being the True Point of Beginning; thence continuing S $00^{\circ} 55^{\prime} 00^{\prime \prime} \mathrm{E}$ a distance of 1502.25 feet; thence $S$ $89^{\circ} 04^{\prime} 36^{\prime \prime} \mathrm{W}$ a distance of 430.57 feet; thence $S 00^{\circ} 53^{\prime} 37^{\prime \prime} \mathrm{E}$ a distance of 123.72 feet; thence $S 89^{\circ} 43^{\prime} 26^{\prime \prime}$ W a distance of 410.23 feet; thence $\mathrm{N} 00^{\circ} 55^{\prime} 00^{\prime \prime} \mathrm{W}$ a distance of 1625.69 feet to the $\mathrm{S}$ right of way margin of Horn Rapids Road; thence N $89^{\circ} 22^{\prime} 24^{\prime \prime}$ E along said S margin a distance of 840.83 feet to the True Point of Beginning.

EXCEPTING FROM THE ABOVE-DESCRIBED LAND THE FOLLOWING PARCELS, EXCLUDING that portion of the Hanford Railroad and any Hanford Site access roads which may traverse these parcels.:

PARCEL A) The N. $1 / 2$ of the N.W. 1/4, and that portion of the N.W. 1/4 of the N.E. $1 / 4$ in sec. 14, T.13N., R.24E.W.M. in the ownership and jurisdiction of the BONNEVILLE POWER ADMINISTRATION.

PARCEL B) Sec. 1, T.11N., R.26E.W.M. in the ownership under quitclaim deed, of the STATE OF WASHINGTON.

PARCEL C) A tract of land leased to the STATE OF WASHINGTON lying in sections 7, 8, and 9, T.12N., R.26E.W.M., containing 1,000 acres more or less, more particularly described as follows: That part of the S. $1 / 2$ of said sec. 7 bounded on the W. and N. by the following described line: BEGINNING at a point on the S. line of said sec. 7, which point is S. $88^{\circ} 44^{\prime} 47^{\prime \prime}$ W. $4,515.30$ feet from the S.E. comer of the sec., and at coordinates N. $438,868.46$ and E. 2,222,800.00 on the Washington State Grid System, South Zone; thence N. 1,781.54 feet; thence E. 2,200.00 feet; thence N. 907.19 feet more or less to the N. line of said S. 1/2 of the sec.; thence N. $88^{\circ} 38^{\prime} 43^{\prime \prime}$ E. along said line 2,275.48 feet more or less to the E. quarter corner of said sec. 7. The S. $1 / 2$ of sec. 8 . The S. $1 / 2$, and the S. $1 / 2$ of the N. $1 / 2$ of sec. 9 , EXCEPT that portion lying easterly of the following described line: BEGINNING at a point on the E. line of said sec. 9 , which point is N. $0^{\circ} 53^{\prime}$ $09^{\prime \prime}$ W. 3,071.71 feet from the S.E. corner of the sec., and at coordinates N. 442,268.92 and E. 2,237,790.19 on the Washington State Grid System, South Zone; thence northwesterly along a 1,055.37 foot radius curve to the right an are distance of $1,064.64$ feet (the chord of said arc bears N. 30 $21^{\prime} 08^{\prime \prime} \mathrm{W} .1,020.05$ feet) to a point on the N. line of the $S .1 / 2$ of the N. $1 / 2$ of said sec. 9 , said point being at coordinates N. 443,149.16 and E. 2,237,274.74 on the Washington State Grid System, South Zone.

Three tracts of land leased to the WASHINGTON PUBLIC POWER SUPPLY SYSTEM more particularly described as follows:

PARCEL D) a tract of land (for the Hanford Generating Plant), commencing at the S.E. corner of sec. 28, T.14N., R.26E.W.M., said point having Washington State Coordinates, South Zone, of N. 486,994.01, and E. $2,236,672.11$; thence N. $72^{\circ} 02^{\prime} 15^{\prime \prime}$ W. $3,483.15$ feet, thence N. $67^{\circ} 11^{\prime} 41^{\prime \prime}$ W. 1,810 feet more or 


\section{HANFORD FACILITY LEGAL DESCRIPTION (cont)}

less to a point on the line of ordinary high water on the right bank of the Columbia River, which point is the TRUE POINT OF BEGINNING: thence S. $67^{\circ} 11^{\prime} 41^{\prime \prime}$ E. 1,810 feet more or less to a point, having Washington State Coordinates, South Zone, of N. 488,068.19 and E. 2,233,358.73, thence N. $22^{\circ} 48^{\prime} 19^{\prime \prime}$ E. a distance of 1,595 feet to a point, having Washington State Coordinates, South Zone, of N. 489,538.48 and E. 2,233,976.96, thence N. $67^{\circ} 11^{\prime} 41^{\prime \prime}$ W. 1,108 feet more or less to a point on the line of ordinary high water on the right bank of the Columbia River, thence southwesterly along the said line of ordinary high water to the TRUE POINT OF BEGINNING, containing 53.42 acres more or less; THIS PARCEL AMENDED BY DELETING THE FOLLOWING: Beginning at the S.E. comer of the leased parcel, which point is at coordinates N. 488,068.19 and E. 2,233,358.73 on the Washington State Coordinate, South Zone; thence N. $22^{\circ} 48^{\prime} 19^{\prime \prime}$ E. 1,060 feet; thence N. $67^{\circ} 11^{\prime} 41^{\prime \prime}$ W. 200 feet; thence S. $22^{\circ} 48^{\prime} 19^{\prime \prime}$ W. 1,060 feet; thence S. $67^{\circ} 11^{\prime} 41^{\prime \prime}$ E. 200 feet to the point of beginning; containing 4.85 acres, more or less;

PARCEL E) a tract of land (for WNP Site 2), beginning at the S.W. comer of sec. 11, T.11N., R.28E.W.M., said corner having Washington State coordinates, South Zone, of N. 408,335.30 and E. $2,307,653.50$, thence N. $0^{\circ} 41^{\prime} 08^{\prime \prime}$ E. 8,065.28 feet to the TRUE POINT OF BEGNNING; thence W. $11,153.57$ feet; thence S. $01^{\circ} 01^{\prime} 23^{\prime \prime}$ E. 3,000.48 feet; thence S. 88 $53^{\prime} 54^{\prime \prime}$ W. $5,200.96$ feet; thence N. $0^{\circ}$ $31^{\prime} 41^{\prime \prime}$ W. $3,690.15$ feet; thence E. 1,430.00 feet; thence N. 1,865.69 feet; thence N. $87^{\circ} 46^{\prime} 08^{\prime \prime}$ E. 3,703.83 feet; thence S. $01^{\circ} 01^{\prime} 23^{\prime \prime}$ E. 1,600.25 feet; thence E. 11,189.29 feet; thence N. $01^{\circ} 01^{\prime} 23^{\prime \prime}$ E. $1,800.29$ feet; thence N. $89^{\circ} 07^{\prime} 55^{\prime \prime}$ E. 3,300.38 feet to the line of Navigation of the W. bank of the Columbia River, thence southerly along said line of Navigation to a point that bears N. $89^{\circ} 15^{\prime} 21^{\prime \prime} \mathrm{E}$. from the TRUE POINT OF BEGINNING; thence $S .89^{\circ} 15^{\prime} 21^{\prime \prime}$ W. $3,850.32$ feet more or less to the TRUE POINT OF BEGINNING.

PARCEL F) A tract of land (for WNP Sites 1 and 4) lying in Section 4 of Township 11 North, Range 28 East, Willamette Meridian, described as follows:

Beginning at the Southwest corner of Section 11, Township 11 North, Range 28 East, W.M., (said corner being located by reference to the Washington State Coordinate System South Zone at coordinates North 408,335.30 and East 2,307,653.50) thence North $65^{\circ}-17^{\prime}-03^{\prime \prime}$ West 12113.14 feet to the TRUE POINT OF BEGINNING (said point being located by reference to the Washington State Coordinate System South Zone at coordinates North $413,400.00$ and East 2,296,650.00); thence North $01^{\circ}-01^{\prime}-23^{\prime \prime}$ West 3000.48 feet to a point; thence East 5280.00 feet to a point; thence South $01^{\circ}-01^{\prime}-23^{\prime \prime}$ East 3000.48 feet to a point; thence West 5280.00 feet more or less to the TRUE POINT OF BEGINNING, containing 363.69 acres more or less; and

A parcel of land lying in Sections 3 and 4 of Township 11 North, Range 28 East, and Sections 33 and 34 of Township 12 North, Range 28 East, Willamette Meridian, described as follows:

Beginning at the Southwest comer of Section 11, Township 11 North, Range 28 East, W.M., (said corner being located by reference to the Washington State Coordinate System South Zone at coordinates North 408,335.30 and East 2,307,653.50) thence North $50^{\circ}-42^{\prime}-00^{\prime \prime}$ West $14,311.63$ feet to the TRUE POINT OF BEGINNING (said point being located by reference to the Washington State Coordinate System South Zone at coordinates North 417,400.00 and East 2,296,578.57); thence North $01^{\circ}-01^{\prime}-23$ " West 3000.48 feet to a point; thence East 5,280.00 feet to a point; thence South $01^{\circ}-01^{\prime}-23^{\prime \prime}$ East 1200.19 feet to a point; thence East 5,973.57 feet to a point; thence South $1^{\circ}-01^{\prime}-23^{\prime \prime}$ West 1800.29 feet to a point; thence West 11,189.29 feet more or less to the TRUE POINT OF BEGINNING, containing 609.15 acres more or less.

PARCEL G) The parcels on the Hanford Site used but not owned by the Bonneville Power Administration including the Ashe Substation, the Hanford Substation, the Benton Switch Substation, and the White Bluffs Substation. 


\section{HANFORD FACILITY LEGAL DESCRIPTION (cont)}

ASHE SUBSTATION. A parcel of land in the W. $1 / 2$ S.E. $1 / 4$, the S.E. $1 / 2$ N.W. $1 / 4$ and the S.W. $1 / 4$ of Section 32, Township 12 North, Range 28 East, Willamette Meridian, Benton County, Washington, more particularly described as follows:

Commencing at a Bonneville Power Administration monument set at the intersection of the northsouth and east-west base lines for the Ashe Substation Site in the S.E. 1/4 S.W. 1/4 of Section 32, Township 12 North, Range 28 East, Willamette Meridian. This monument is located N.26 $49^{\prime} 15^{\prime \prime} \mathrm{E}$., 1503.1 feet from a 2-inch brass disc on the south line of Section 32, said disc being set by WPPSS survey of August 11, 1971. Thence N.52 $2^{\circ} 10^{\prime} 10^{\prime \prime}$ E., 1200.0 feet to the true point of beginning. Thence $S .37^{\circ} 49^{\prime} 50^{\prime \prime} E$., 400.0 feet; thence $\mathrm{S} .52^{\circ} 10^{\prime} 10^{\prime \prime} \mathrm{W}, 1_{100.0}$ feet; thence $\mathrm{S} .37^{\circ} 49^{\prime} 50^{\prime \prime} \mathrm{E} ., 1287.7$ feet to a point on the south line of Section 32 ;

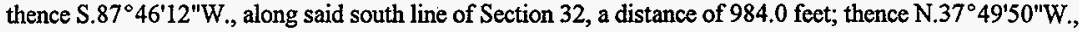
2014.8 feet; thence N.52 $10^{\prime} 10^{\prime \prime} E$., 1900.0 feet; thence $S .37^{\circ} 49^{\prime \prime} 50^{\prime \prime} \mathrm{E} ., 900.0$ feet to the true point of beginning; containing 75.09 acres, more or less.

ASHE SS SOUTH CORRIDOR, PARCEL 1. A portion of Government Lot 3 of Section 5, Township 11 North, Range 28 East, Willamette Meridian, Benton County, Washington, more particularly described as follows:

Commencing at a point in Bay 3 in the Ashe Substation Site in the N.E. 1/4 S.W. 1/4 of Section 32, Township 12 North, Range 28 East, Willamette Meridian, said point being N.25 $56^{\prime} 16^{\prime \prime} \mathrm{E}$., 1716.1 feet from a 2-inch brass disc on the south line of Section 32, said disc being set by WPPSS survey of August 11, 1971. Thence S.31 ${ }^{\circ} 24^{\prime} 10^{\prime \prime} E$., 553.5 feet; thence S. $1^{\circ} 50^{\prime} 00^{\prime \prime} \mathrm{E}, 1029.6$ feet to a point on the north line of Section 5 , Township 11 North, Range 28 East, Willamette Meridian, the true point of beginning for this description. Thence N. $87^{\circ} 46^{\prime} 12^{\prime \prime} \mathrm{E}$, along said north line of Section 5, a distance of 75 feet; thence S.1 ${ }^{\circ} 50^{\prime} 00^{\prime \prime} \mathrm{E}$., 1299.7 feet; thence S.88 $10^{\prime} 00^{\prime \prime} \mathrm{W}, 281.5$ feet; thence N. $1^{\circ} 50^{\prime} 00^{\prime \prime} \mathrm{W}$., 1297.6 feet to a point on said north line; thence N.87 $46^{\circ} 12^{\prime \prime} \mathrm{E}$, along said north line, a distance of 206.5 feet to the true point of beginning.

ASHE SS SOUTH CORRIDOR, PARCEL 2. All that portion of the S.E. 1/4 S.W. 1/4 of Section 32, Township 12 North, Range 28 East, Willamette Meridian, Benton County, Washington, that lies southerly and easterly of the Ashe Substation Site and westerly of a line 75 feet easterly from and parallel with the survey line for the Bonneville Poser Administration WPPSS No. 2 Powerhouse-Ashe $500 \mathrm{kV}$ line No. 2. The survey line is described, with reference to the Washington Coordinate System - South Zone, as follows:

Beginning at a point in Bay 3 in the Ashe Substation Site in the N.E. 1/4 S.W. 1/4 of Section 32, Township 12 North, Range 28 East, Willamette Meridian, at a survey Station $97+84.0$, said point being N. $25^{\circ} 56^{\prime} 16^{\prime \prime}$ E., 1716.1 feet from a 2-inch brass disc on the south line of Section 32, said disc being set by WPPSS survey of August 11, 1971. Thence S. $31^{\circ} 24^{\prime} 10^{\prime \prime}$ E., 553.5 feet to station $92+30.5$; thence S. $1^{\circ} 50^{\prime} 00^{\prime \prime E}$., 1029.6 feet to a point on the south line of Section 32 , said point being N.87 $46^{\prime} 12^{\prime \prime} E$., 1072.1 feet from said brass disc.

ASHE-SS-AR-1. A portion of Lot 3 S.1/2 N.W. 1/4, and N.W. 1/4 S.W. $1 / 4$ of Section 5, the E. 1/2 S.E. $1 / 4$ and S.W. 1/4 S.E. $1 / 4$ of Section 6 , the N.W. 1/4 N.E. $1 / 4$ and E. $1 / 2$ N.W. $1 / 4$ of Section 7 , Township 11 North, Range 28 East, Willamette Meridian, Benton County. Washington.

HANFORD SUBSTATION SITE. Lot 1 of Block 8, Lots 13 and 14 of Block 9, and Lot 8 of Block 10 of Hanford, according to the recorded plat thereof, and that part of Thirteenth Street lying between the northeasterly line of Tract A of Hanford, according to the recorded plat thereof and the Columbia River, and that part of Dunham Street lying southeasterly of a line connecting the northwesterly lines of Lot 8 of Block 10 and Lot 13 of Block 9 of Hanford, according to the recorded plat thereof, all in Section 25, Township 13 North, Range 27 East, Willamette Meridian Benton County, Washington, containing 2.7 acres, more or less. Subject to easement to Pacific Power \& Light Company for power line and access purposes. 


\section{HANFORD FACILITY LEGAL DESCRIPTION (cont)}

BENTON SWITCH SUBSTATION. A parcel of land in the N.W. 1/4 of Section 11, Township 11 North, Range 28 East, Willamette Meridian, Benton County, Washington, described with reference to the Washington Coordinate System - South Zone, as follows:

Beginning at the northwest corner of said parcel, being S.54 ${ }^{\circ} 50^{\prime} \mathrm{E}$., 1804.0 feet more or less from the northwest corner of said Section 11 ; thence N. $49^{\circ} 13^{\prime} 45^{\prime \prime} \mathrm{E}$., 550.0 feet to the northeast corner, evidenced by a brass cap; thence $S .40^{\circ} 46^{\prime} 15^{\prime \prime} \mathrm{E}$., 500.0 feet to the southeast corner, evidenced by a brass cap; thence $\mathrm{S} .49^{\circ} 13^{\prime} 45^{\prime \prime} \mathrm{W} ., 550.0$ feet to the southwest corner, evidenced by a brass cap; thence N. $40^{\circ} 46^{\prime} 15^{\prime \prime} \mathrm{W}$., 500.0 feet to the point of beginning. The described parcel contains 6.31 acres, of which 2.75 acres lie within the boundaries of the existing Benton Switching Station.

WHITE BLUFFS SUBSTATION. A parcel of land in Government Lots 3 and 4 and the E. $1 / 2$ S.W. 1/4 of Section 7, Township 10 North, Range 28 East, Willamette Meridian, Benton County, Washington, more particularly described as follows:

Commencing at a Bonneville Power Administration monument in said Government Lot 4 at the intersection of the east-west and north-south base lines for the White Bluffs Substation Site, said monument being N.36 $45^{\prime} 35^{\prime \prime} \mathrm{E}, 1623.7$ feet from the southwest comer of Section 7 . This corner is evidenced by a rock mound. Thence N.72 $55^{\prime} 20^{\prime \prime} \mathrm{W}$., along the east-west base line, a distance of 500 feet to the true point of

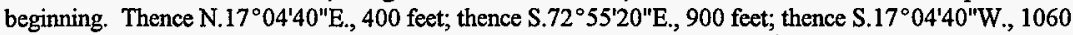
feet, more or less, to a point 40 feet north of the centerline of Hom Rapids Road; thence N.72 ${ }^{\circ} 55^{\prime} 20^{\prime \prime} \mathrm{W} ., 900$ feet., thence $\mathrm{N} .17^{\circ} 04^{\prime} 40^{\prime \prime} \mathrm{E}$., 660 feet, more or less, to the true point of beginning, containing 21.90 acres, more or less.

For purposes of application of Part IV Corrective Action of the Hanford Facility Permit only, the Hanford Facility also includes PARCELS C, D, E, F, and G of the lands identified as Excepted from the ABOVE-DESCRIBED LAND, in the foregoing legal description. 


\section{APPENDIX 2D}

SOLID WASTE MANAGEMENT UNITS 
2

3

4

5

6

8

9

10

11

12

13

14

15

\section{APPENDIX 2D}

\section{CONTENTS}

1.0 SOLID WASTE MANAGEMENT UNITS AND KNOWN AND SUSPECTED

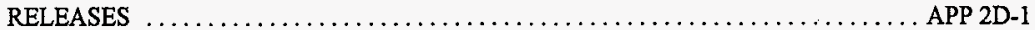

1.1 WASTE INFORMATION DATA SYSTEM APP 2D-2

1.2 HANFORD SITE WASTE MANAGEMENT UNITS REPORT APP 2D-2

1.3 SET OF SOLID WASTE MANAGEMENT UNITS TOPOGRAPHICAL MAPS APP 2D-2

2.0 CORRECTIVE ACTIONS IMPLEMENTED APP 2D-2 


\section{SOLID WASTE MANAGEMENT UNITS}

The requirement to address SWMUs at a RCRA Facility was enacted as part of the HSWA to RCRA [under Section 3004(u), "Continuing Releases At Permitted Facilities"]. Section 3004(u) states:

"Standards promulgated under this section shall require, and a permit issued after the date of enactment of the Hazardous and Solid Waste Amendments of 1984 by the administrator or a State shall require, corrective action for all releases of hazardous waste or constituents from any solid waste management unit at a treatment, storage, or disposal facility seeking a permit under this subtitle, regardless of the time at which waste was placed in such unit. Permits......."

Because this requirement is part of the HSWA, the EPA regulations for implementing Section 3004(u) currently are proposed under 40 CFR 264, Subpart S (264.501 through 264.560). The definition of a corrective action management unit and temporary unit were finalized on February 16, 1993. These definitions are promulgated at 40 CFR Part 264.552 and Part 264.553, respectively of 40 CFR Part 264, Subpart $\mathbf{S}$.

\subsection{SOLID WASTE MANAGEMENT UNITS AND KNOWN AND SUSPECTED RELEASES}

Currently, over 2,000 waste management units have been identified within the Hanford Site, the majority of which are identified as SWMUs in accordance with the RCRA. These waste management units are tabulated and described in the Units Report (DOE/RL-88-30). As surveys and scoping studies are performed in support of the ongoing onsite cleanup program, additional SWMUs likely will be identified. The amount of information that currently exists for individual SWMUs varies significantly. It is intended that SWMUs be investigated in accordance with the past-practice process of the Tri-Party Agreement (refer to Chapter 2.0, Section 2.5). In support of the issuance of a Hanford Facility RCRA permit, the EPA conducted an initial RCRA Facility Assessment. If necessary, follow-on assessments, scoping studies, and investigations will be conducted in accordance with the Tri-Party Agreement to obtain additional information on currently identified SWMUs and newly identified SWMUs.

Conditions pertaining to SWMUs are contained in the HF RCRA Permit as follows: Condition II.I. 1.a. of Part II (DW Portion), Part III (DW Portion), and Part IV (HSWA Portion) (refer to Chapter 2.0, Section 2.1.1.3). In support of Condition II.I.1.a. of the HF RCRA Permit (DW Portion), all known SWMUs must be identified and mapped, including any releases of dangerous waste (or constituents) from these units. Because of the number and complexity of SWMUs on the Hanford Site, the proposed approach to satisfy the requirements for identifying and updating SWMUs and releases from SWMUs uses a combination of the following:

- Hanford Waste Information Data System (WIDS)

- Units Report

- Set of SWMU topographical maps. 


\subsection{WASTE INFORMATION DATA SYSTEM}

The WIDS is an electronic database that identifies known and reported SWMUs located within the DOE-RL controlled area (i.e., area on the Hanford Site over which DOE-RL has responsibility). The WIDS also includes other waste management units (i.e., non-SWMUs) in support of the overall cleanup mission of the Hanford Site. These non-SWMUs include one-time spills, domestic sewage sites, and structures awaiting decontamination and decommissioning. The SWMUs are clearly designated from the non-SWMUs within the WIDS. The WIDS includes the type and location of the unit, when the unit was operated, general dimensions and description, and general descriptions of waste placed in the unit to include estimated quantities of radionuclides and chemicals contained in some units. As additional information on the SWMUs is made available, this information is entered into the WIDS. The WIDS will be used as the official listing of . SWMUs for the DOE-RL controlled area. The EPA and Ecology have been provided with electronic access to the database.

As additional SWMUs are identified as a result of investigations and scoping studies conducted within the DOE-RL controlled area, the SWMUs will be entered into the WIDS, along with required information concerning the unit. A special electronic file will be maintained within the WIDS system that identifies all SWMUs that have been entered into the system within the last 30 days. This will satisfy the requirement established by Condition III.F of the HF RCRA Permit (HSWA Portion) for notification of newly identified SWMUs. A second electronic file will be maintained to show all previously entered SWMUs whose descriptive data have been modified within the last 30 days. This file will be accessible upon request. Modifications will include newly discovered information concerning releases of hazardous materials from the SWMUS.

\subsection{HANFORD SITE WASTE MANAGEMENT UNITS REPORT}

The Units Report (DOE/RL-88-30) provides summary information on each waste management unit contained within the WIDS. In accordance with Section 3.5 of the Tri-Party Agreement Action Plan, the Units Report is reissued in January of each year, if determined necessary by representatives of the three parties (i.e., DOE-RL, EPA, and Ecology). Each update reflects waste management units added to the database since the preceding report, along with updated information on all units.

\subsection{SET OF SOLID WASTE MANAGEMENT UNITS TOPOGRAPHICAL MAPS}

Information on obtaining SWMU maps is contained in Appendix $\mathrm{C}$ of the Units Report (refer to Appendix $2 \mathrm{~A}$ of this document).

\subsection{CORRECTIVE ACTIONS IMPLEMENTED}

Schedules to implement any corrective actions for the DOE-RL controlled area will be developed and maintained within the Tri-Party Agreement (refer to Chapter 2.0, Section 2.5). All identified SWMUs have been assigned to operable units within the Tri-Party Agreement along with other waste management units. Newly identified SWMUs will be assigned to the appropriate operable unit via the Tri-Party Agreement change control process outlined in Chapter 12.0 of the Action Plan. Either CERCLA response action 
1 authority or RCRA corrective action authority is assigned as the prime authority for the investigation and 2 cleanup process for each operable unit. The schedules of compliance for those assigned RCRA corrective 3 action authority are considered as part of the HF RCRA Permit via reference to the Tri-Party Agreement. 4 The Tri-Party Agreement change control process will be used to modify the schedules of compliance as 5 necessary, meeting the intent of 40 CFR 270.34 (proposed). Remedy selections, either as a corrective 6 measure or as an interim measure, will be incorporated into modifications of the HF RCRA Permit.

The schedules of compliance will include any follow-on RCRA Facility Assessments that might be 9 conducted, RCRA facility investigations, corrective measure studies, and corrective measure

10 implementations. The schedules also will include any interim measures that are identified to be conducted. 
This page intentionally left blank. 


\section{J. R. Wilkinson}

Department of Natural Resources

Confederated Tribes of the Umatilla Indian Reservation

P. O. Box 638

Pendleton, OR 97801

Russell Jim, Manager

Environmental Restoration/Waste Management

Confederated Tribes and Bands of the Yakama Nation

P. O. Box 151

Toppenish, WA 98948

Donna Powaukee

Nez Perce Tribe

P. O. Box 305

Lapwai, ID 80540

\section{ONSITE U.S. Department of Energy, Richland Operations Office}

L. K. Bauer

$\mathrm{H} 0-12$

R. M. Carosino

A4-58

C. E. Clark

A5-15

C. A. Hansen

S7-41

J. E. Kinzer

S7-50

P. M. Knollmeyer

A5-11

E. M. Mattlin

A. C. McKarns

R. M. Rosselli

A5-15

Reading Room (2)

Bechtel Hanford, Inc.

R. J. Landon

H0-18

P. J. Mackey

$\mathrm{H} 0-09$

L. A. Mihalik

H9-01

G. S. Robinson

Pacific Northwest National Laboratory

S. D. Cooke

B. J. Day

P7-28

G. W. McNair 
Pacific Northwest National Laboratory (cont)

M. J. Riess

P8-35

C. J. Simiele

P8-45

H. T. Tilden

P7-79

Hanford Technical Library

K1-11

Eluor Daniel Hanford, Inc.

A. G. Miskho

H6-23

S. M. Price

H6-23

F. A. Ruck III

H6-23

B. D. Williamson

B3-15

B \& W Hanford Company

K. A. Hadley (6)

R3-56

DynCorp

B. J. Dixon

B4-20

Lockheed Martin Hanford Corp.

B. G. Erlandson (2)

R2-36

Numatec Hanford Corp.

R. A. Kaldor

H5-25

Waste Management Federal Services of Hanford, Inc.

S. B. Clifford

H6-26

R. H. Englemann

H6- 26

D. B. Jensen (RCRA file)

H6-26

J. C. Sonnichsen

H6-26

J. A. Winterhalder (5)

H6-21

Lockheed Martin Services, Inc.

Central Fíles

B1-07

DPC

H6-08

EDMC (2)

H6-08 